\title{
eco TSP
}

ESCOLA DE COMUNIÇAÇÕES E ARTES

UNIVERSIDADE DE SÃO PAULO

TATIANA ANCHIESCHI GOMES MAZZEI

Câmbios estéticos de um mito moderno: a figura do anjo na publicidade 


\section{TATIANA ANCHIESCHI GOMES MAZZEI}

Câmbios estéticos de um mito moderno: a figura do anjo na publicidade

Dissertação apresentada ao Departamento de Relações Públicas, Propaganda e Turismo do Programa de Pós-Graduação em Ciências da Comunicação na Escola de Comunicações e Artes (ECA/USP) da Universidade de São Paulo, como requisito para obtenção do título de Mestre.

Área de concentração: Teoria e Pesquisa em Comunicação

Orientador: Prof. Dr. Victor Aquino Gomes Correa.

\section{SÃO PAULO}


Autorizo a reprodução e divulgação total ou parcial deste trabalho, por qualquer meio convencional ou eletrônico, para fins de estudo e pesquisa, desde que citada a fonte.

Catalogação na Publicação Serviço de Biblioteca e Documentação

Escola de Comunicações e Artes da Universidade de São Paulo Dados fornecidos pelo(a) autor(a)

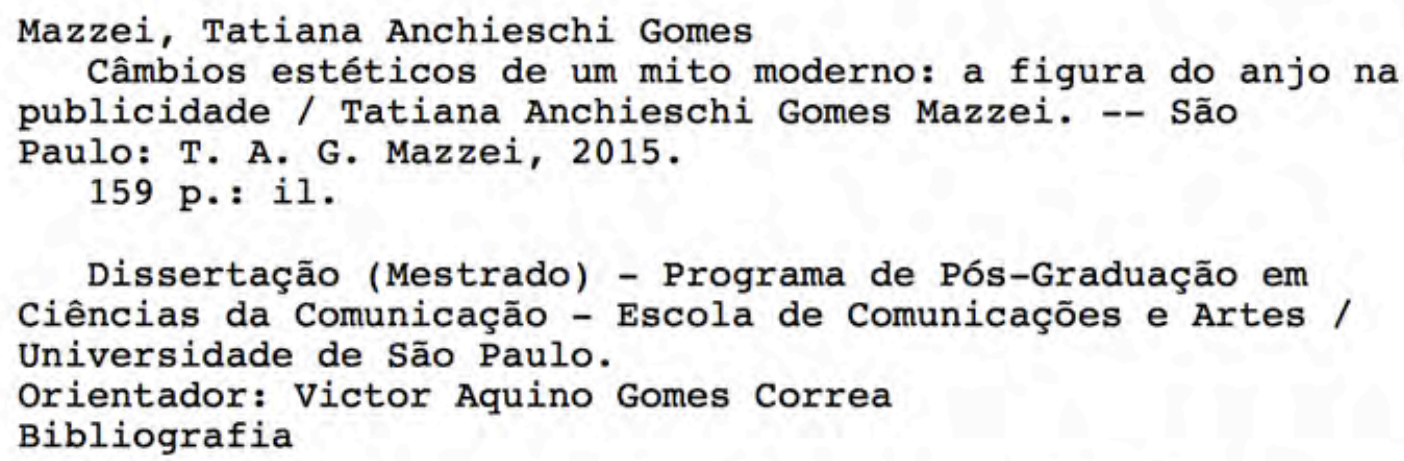

1. anjo 2. estética 3. publicidade 4 . mito 5 . arquétipo I. Correa, Victor Aquino Gomes II. Título.

CDD 21.ed. - 659.1 


\section{Nome: MAZZEI, TATIANA ANCHIESCHI GOMES}

Título: Câmbios estéticos de um mito moderno: a figura do anjo na publicidade

Dissertação apresentada à Escola de Comunicações e Artes da Universidade de São Paulo para obtenção de título de Mestre em Teoria e Pesquisa em Comunicação.

Aprovada em:

\section{BANCA EXAMINADORA}

Prof. Dr.:

Instituição:

Julgamento:

Assinatura:

Prof. Dr.:

Instituição:

Julgamento:

Assinatura:

Prof. Dr.:

Julgamento:

Instituição:

Assinatura:

Prof. Dr.:

Instituição:

Julgamento:

Assinatura: 
Aos meus estimados pais, José Carlos e Lucrécia, pelos inúmeros ensinamentos, por todos os incentivos pessoais e profissionais, por acreditarem em mim sempre com entusiasmo e por permitirem que eu me tornasse um ser humano melhor, fatores estes indispensáveis para a realização deste trabalho. Ao meu marido Luiz Carlos, pelo seu amor, admiração e minha eterna gratidão por sua compreensão e carinho, que foram vitais como apoio ao longo de toda esta jornada. 


\section{AGRADECIMENTO}

Ao meu caríssimo orientador Prof. Dr. Victor Aquino Gomes Correa (USP) pela confiança, paciência e por acreditar na realização deste projeto de pesquisa.

A Profa. Dra. Mayra Rodrigues Gomes, Professora do Departamento de Jornalismo e Editoração da ECA-USP e ao Prof. Dr. Osvaldo Humberto Leonardi Ceschin Professor da Faculdade de Filosofia Letras e Ciências Humanas (FFLCH) por aceitarem compor minha banca de qualificação e por todas as sugestões e análises significativas às quais busquei aplicar neste trabalho.

Aos professores, funcionários e colegas do Programa de Pós-Graduação em Ciências da Comunicação da Escola de Comunicações e Artes (ECA/USP).

Aos professores Sandra Trabucco Valenzuela, Josefa Gomes de Farias, Joviniano Borges da Cunha, Ana Lúcia de Alcântara Oshiro e Ana Maria Ramaglia Silveira, docentes da Universidade Anhembi Morumbi, pelas recomendações e empréstimos de livros, pelas inúmeras reflexões e críticas e por todas as sugestões recebidas.

Aos meus pais, meus primeiros mestres, que despertaram em mim o prazer de lecionar e cujos ensinamentos diários permitiram que eu seguisse seus passos, adotando também esta valorosa profissão. Obrigada por me ensinarem valores morais num mundo às vezes tão imoral e por terem permitido que eu pudesse andar com meus próprios pés, porém nunca me deixando sozinha nesta caminhada.

A meu amado pai (in memoriam), onde quer que esteja saiba o quanto sou grata por toda a confiança e orgulho que sempre teve de mim.

Aos meus irmãos gêmeos Gustavo e Olavo que permitiram que eu me tornasse um ser ainda mais responsável e que como irmã mais velha chamasse para mim o cuidado de toda nossa família. 
“Como os sonhos, os mitos são produtos da imaginação humana. Suas imagens, em consequência, embora oriundas do mundo material e de sua suposta história, são como os sonhos, revelações das mais profundas esperanças, desejos e temores, potencialidades $e$ conflitos da vontade humana (...)" (CAMPBELL, 2004, p.40) 
MAZZEI, Tatiana Anchieschi Gomes. CÂMBIOS ESTÉTICOS DE UM MITO MODERNO: a figura do anjo na publicidade. São Paulo, 2015. 159 f. Dissertação (Mestrado em Teoria e Pesquisa em Comunicação) - Escola de Comunicações e Artes, Universidade de São Paulo, São Paulo, 2015.

\section{RESUMO}

Este trabalho objetiva investigar e compreender sobre os câmbios estéticos da figura do anjo na publicidade e suas inúmeras significações representadas simbolicamente em campanhas e anúncios. Por ser objeto de estudo ressurgente, o anjo torna-se mito atemporal, que transpassa os séculos, atualizando-se como imagem, a fim de adaptar-se aos preceitos da contemporaneidade.

Em face disso, esta produção científica será embasada em pesquisa teórica e qualitativa obtendo resultados através da coleta de anúncios retirados de meios impressos e internet, tendo como suporte antropológico a História da Arte e consequentemente o campo da Estética da Comunicação.

Visa, dessa forma, compreender o mito alado e seu desmembramento em arquétipos, de maneira que permita analisar a utilização do símbolo como linguagem, pois ao permitir que a leitura do mundo seja realizada através do seu constante ressurgimento como mito, o anjo se recontextualiza através de mudanças estéticas, buscando tornar-se sempre atual para a sociedade, sendo representado imageticamente de distintas formas na publicidade.

Palavras-chave: anjo; estética, publicidade, mito, arquétipos. 
MAZZEI, Tatiana Anchieschi Gomes. AESTHETICS EXCHANGE OF A MODERN MYTH: the angel figure in advertising. São Paulo, 2015. 159 f. Dissertation (Master in Theory and Research in Communication) - Escola de Comunicações e Artes, Universidade de São Paulo, São Paulo, 2015.

\begin{abstract}
This study has the objective to investigate and understand about the aesthetic changes at Angel figure in the advertising and its many meanings, represented symbolically in campaigns and ads.

By be object of study resurgent, the angel becomes timeless myth that pierces the centuries and has been updated as image in order to adapt to the precepts of contemporary times.

On the face of it, this scientific output will be grounded in research theoric and qualitative, through getting results by collecting removed ads from printed and internet media, having as anthropological support the Art history and consequently the field of Aesthetics of Communication .

Visa thus understand the winged myth and its dismemberment in archetypes, so that the analysis of the use of this symbol as language, can allowing the reading of the world through of its constant resurgence as myth, this way the angel is recontextualised through changes aesthetic, seeking to become ever present to society and be represented imagetically in different ways in the advertising.
\end{abstract}

Keywords: angel; aesthetics, advertising, myth, archetypes. 


\section{LISTA DE TABELAS}

Tabela 1 - Diferentes representações de Eros 42

Tabela 2 - Conceitos originados do Renascimento e do Barroco.................................. 78

Tabela 3 - Elementos qualitativos dos anjos no cinema........................................... 92

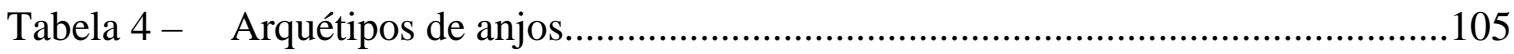




\section{LISTA DE GRÁFICOS}

Gráfico 1 - Esquema gráfico de construção do mito do anjo na publicidade....................... 102

Gráfico 2 - O que as pessoas acreditam ou não?........................................................ 109

Gráfico 3 - O que as pessoas acreditam ou não? (por geração e ideologia política)........... 111 


\section{LISTA DE ILUSTRAÇÕES}

Figura 1 - O Faravahar - símbolo da representação da alma humana no Zoroastrismo.... 25

Figura 2 - Talmude - O livro sagrado do Judaísmo....................................................... 26

Figura 3 - Amuleto egípcio em ouro do Deus Bá........................................................... 29

Figura 4 - Joia para ornamentação peitoral representando Ra-Harakhty ....................... 29

Figura 5 - Joia peitoral de Tutancâmon com escaravelho alado.................................... 30

Figura 6 - $\quad$ Figura da deusa Ma'at alada ajoelhada ladeada por cartelas de Seti I............. 30

Figura 7 - Representação gráfica da deusa Mut........................................................ 31

Figura 8 - Joia peitoral da deusa Nut.................................................................... 31

Figura 9 - Portões do palácio do rei Sargon II em Dur Sharrukin na Assíria................... 32

Figura 10 - Estatueta do demônio assírio Pazuzu.............................................................. 33

Figura 11 - Baixo-relevo de Nice - deusa da vitória....................................................... 35

Figura 12 - Estátua da deusa Vitória.......................................................................... 36

Figura 13 - Friso "Gigantomaquia" - Altar de Pérgamo................................................ 36

Figura 14 - Estátua de Mercúrio no Museu Bureau Monumentenzorg ............................. 38

Figura 15 - Jarro ilustrando Hypnos e Thanatos carregando o corpo de Sarpedon............. 39

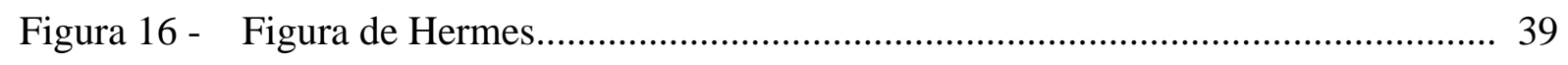

Figura 17 - Prato em terracota com a figura de Eros....................................................... 40

Figura 18 - Cupido e Psyche - Guillaume Seignac......................................................... 41

Figura 19 - Renascimento de Psyche -- Antonio Canova................................................. 42

Figura 20 - Cupido dormindo - Caravaggio............................................................... 42

Figura 21 - Psyche e o Amor - William-Adolphe Bouguereau...................................... 42

Figura 22 - Psyche e o Amor - François Pascal Simon Gérard ...................................... 42

Figura 23 - Amor e Psyche - Louis Jean Francois Lagrenée........................................... 43

Figura 24 - Eros - Atribuído a Douris - Cleveland Museum of Art................................... 43

Figura 25 - Vaso Pompeu entre Eros e Dionísio - Século IV a.C..................................... 43

Figura 26 - Tânatos - Escultura em mármore - 325-300 b.C............................................. 44

Figura 27 - Hárpia - Fragmento de friso da tumba de Kybernis, acrópole de Xantos......... 44

Figura 28 - A hierarquia dos anjos segundo Dionísio...................................................... 48

Figura 29 - Santo Tomás de Aquino retratado por Fra Bartolommeo................................ 49

Figura 30 - A hierarquia dos anjos segundo Tomás de Aquino....................................... 50

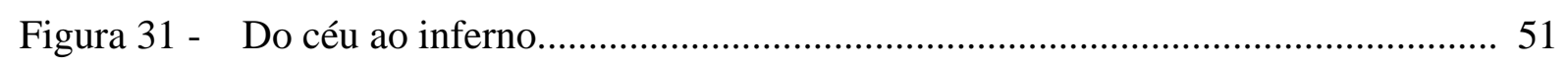




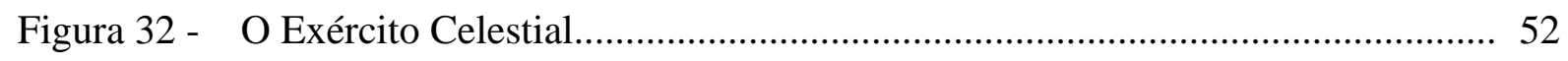

Figura 33 - O Exército Celestial (cont.)...................................................................... 53

Figura 34 - Estátua do Anjo do Norte - Antony Gormley................................................ 57

Figura 35 - A queda de Lúcifer - Revista Mundo Estranho - Ed. Set/2013 ...................... 58

Figura 36 - A queda de Lúcifer - Revista Mundo Estranho - Ed. Set/2013 (cont.).......... 59

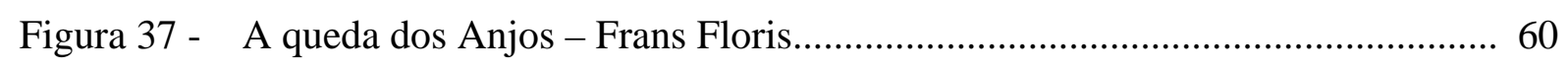

Figura 38 - A lamentação - Giotto di Bondone........................................................... 66

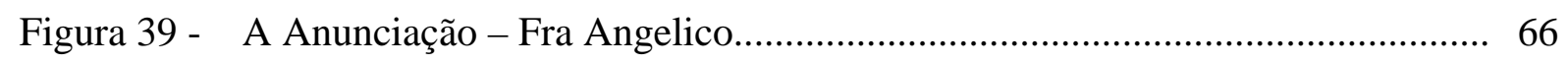

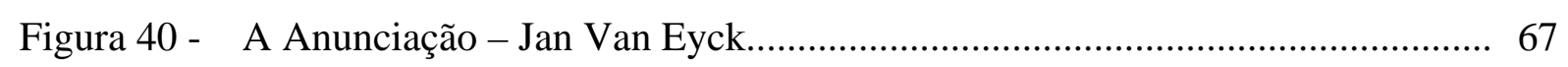

Figura 41 - A Anunciação de um evangelho manuscrito suábio........................................ 68

Figura 42 - O nascimento de Vênus - Sandro Botticelli................................................. 70

Figura 43 - A Anunciação - Leonardo Da Vinci........................................................... 72

Figura 44 - A Criação de Adão - Michelângelo.............................................................. 73

Figura 45 - O juízo final- Michelângelo......................................................................... 73

Figura 46 - O grande São Miguel - Rafael Sanzio.................................................... 75

Figura 47 - Madona Sistina - Rafael Sanzio.............................................................. 76

Figura 48 - São Miguel lutando contra o dragão - Albretch Dürer.................................... 77

Figura 49 - Melancolia - Albretch Dürer..................................................................... 77

Figura 50 - Ornamentação da Igreja de São Francisco de Assis - Mestre Ataíde............. 79

Figura 51 - Detalhe da Igreja de São Francisco de Assis - Mestre Ataíde....................... 80

Figura 52 - Angelus Novus - Paul Klee..................................................................... 81

Figura 53 - Anatomia de um anjo - Damien Hirst....................................................... 82

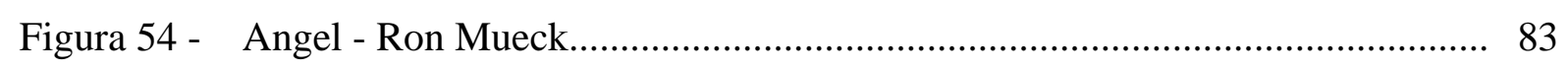

Figura 55 - Angel - Sun Yu e Peng Yu .................................................................. 84

Figura 56 - Céu e purgatório na Divina Comédia de Dante Alighieri................................ 87

Figura 57 - Inferno na Divina Comédia de Dante Alighieri............................................... 88

Figura 58 - Pôster da peça teatral “Angels in America”................................................... 95

Figura 59 - Pôster da minissérie "Angels in America" produzida pelo canal HBO............ 96

Figura 60 - Crítica sobre “Angels in America” no Brasil - Data: 05/05/1995.................... 97

Figura 61 - Crítica sobre "Angels in America” no Brasil - Data: 17/07/1995.................... 98

Figura 62 - Exemplos de produtos baseados na figura do Anjo......................................... 108

Figura 63 - Capa Revista Time - Edição Dez/1993 ….................................................... 109

Figura 64 - Anúncios publicitários antigos com a presença da figura do anjo................... 113 
Figura 65 - Anúncio para Ministério Público do Trabalho - Paim Comunicação.............. 114

Figura 66 - Anúncios para a Companhia Energética de Minas Gerais - Perfil 252........... 115

Figura 67 - Anúncio Ecovias sobre o uso de cadeirinha infantil - Terremoto Propaganda. 116

Figura 68 - Anúncios para HAAD - Heatlh Autority Abu Dabhi - BPG Group............... 116

Figura 69 - Anúncio do carro Classe A 2002 da Mercedes Benz - W/Brasil.................... 117

Figura 70 - Anúncio para marca automotiva Chrysler - BBDO Puerto Rico.................... 118

Figura 71 - Anúncio para marca de roupas para neve Polarguard - Agência KNSK........ 118

Figura 72 - Anúncio para empresa de transportes seguros Boxman - M\&C Saatchi........ 119

Figura 73 - Evolução estética do anjo em relação à sexualidade e gênero......................... 121

Figura 74 - Anúncios com Cupido - Pear's Soap, Green Giant Peas e Tiffany \& Co....... 122

Figura 75 - Logotipo Fiorucci e os anjos de Rafael de Sanzio no quadro Madona Sistina. 123

Figura 76 - Anúncio “Angel and Demon” - Benetton por Oliviero Toscani...................... 123

Figura 77 - Anúncio para cream cheese Philadelphia - J. Walter Thompson..................... 124

Figura 78 - Anúncio para o perfume Heavenly - Victoria Secret's.................................. 125

Figura 79 - Anúncio para bar \& boite de striptease Play Man......................................... 126

Figura 80 - Anúncios para divulgação da ONG PETA e da água Evian............................ 127

Figura 81 - Anúncios da figura do anjo com asas estilizadas......................................... 127

Figura 82 - Anúncios polêmicos para celulares da marca Virgin Mobile.......................... 128

Figura 83 - Anúncio para GAPA/BS visando o combate à Aids.................................... 129

Figura 84 - Anúncio para sexshop Anjo Sado em busdoor............................................ 130

Figura 85 - Anúncio para MTV Brasil........................................................................ 131

Figura 86 - Anúncio da transportadora american Xpress Movers.................................... 132

Figura 87 - Anúncio para detergente Tide - Procter \& Gamble...................................... 132

Figura 88 - Anúncio com anjo picado por insetos criado para o Inseticida Bloom........... 133

Figura 89 - Anúncios para inseticidas Baygon e Vapona................................................ 134

Figura 90 - Anúncio para dedetizadora Truly Nolen........................................................ 134

Figura 91 - Anúncio para ONG Save the Children ..................................................... 135

Figura 92 - Anúncio Anjos para Itaú Seguros - 2000...................................................... 136

Figura 93 - Anúncio Anjos para Itaú Seguros - 2001.................................................... 136

Figura 94 - Anúncio para seguro saúde Unimed............................................................ 137

Figura 95 - Anúncio para serviços financeiros da Allianz.............................................. 138

Figura 96 - Anúncio da empresa automobilística BMW - Suíça...................................... 139

Figura 97 - Anúncio para site de encontros amorosos El Sitio - Argentina...................... 139 
Figura 98 - Anúncio para empresa de cosméticos Marie France Bodyline........................ 140

Figura 99 - Anúncio para cartão de crédito Capital One................................................... 141

Figura 100 - Campanha publicitária para restaurante italiano Gondola Veneziana............. 142

Figura 101 - Anúncio para Procter \& Gamble - Vidal Sassoon......................................... 143

Figura 102 - Anúncio para marca de calçados de numeração grande - Pé de anjo............... 143

Figura 103 - Anúncio para máscara facial Neutrogena - China........................................ 144

Figura 104 - Anúncio do perfume Ange ou Démon da Givenchy com Uma Thurman....... 146

Figura 105 - Anúncio para desodorante masculino Axe Excite - Porto Rico...................... 147

Figura 106 - Anúncios para desodorante masculino Axe Excite - “Até os anjos cairão”.... 148

Figura 107 - Anúncio para Diesel com a presença da figura de anjos............................... 149

Figura 108 - Anúncios para Vodka SKYY, Martini e Ballantine's.................................. 150

Figura 109 - Anúncio para pneus Angel ST da Pirelli.................................................. 151

Figura 110 - Anúncio para documentário na ITV Injustice - Inglaterra............................ 151

Figura 111 - Anúncio para corretivo Paper Mate............................................................ 152 


\section{LISTA DE ABREVIATURAS E SIGLAS}

a.C. Antes de Cristo

AIDS Acquired Immunodeficiency Syndrome

AZT Azidotimidina

BBH Bartle Bogle Hegarty

BPG Bates Pan Gulf

BMW Bayerische Motoren Werke

CEMIG Companhia Energética de Minas Gerais

d.C. Depois de Cristo

GAPA/BS Grupo de Apoio à Prevenção à AIDS da Baixada Santista

GM Genealogia da Moral

HAAD Heatlh Autority Abu Dabhi

HIV Human Immunodeficiency Virus

ITV Independent Television

MTV Music Television

OVNI's Objetos Voadores Não Identificados

PETA People for the Ethical Treatment of Animals

ST Sport Touring

UFO's Unknown Flying Objects 


\section{SUMÁRIO}

INTRODUÇÃ̃

1. ETIMOLOGIA, SIGNIFICAÇÃO E ANTECEDENTES HISTÓRICOS DA FIGURA DO ANJO .......... 21

1.1. OS SERES ALADOS DA MITOLOGIA EGÍPCIA ........................................................ 28

1.2. O PANTEÃO DOS DEUSES DA MITOLOGIA ASSÍRIA E SUMÉRIA ................................ 31

1.3. MITOLOGIA GREGA: A PEDRA FUNDAMENTAL DOS MITOS MUNDIAIS..................... 33

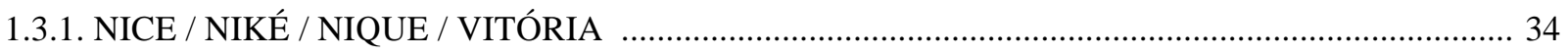

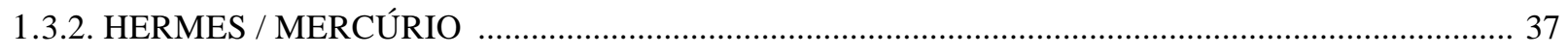

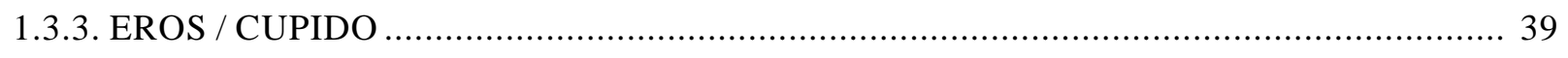

1.3.4. DE ÍCARO E MORFEU A TÂNATOS E AS HÁRPIAS ................................................ 43

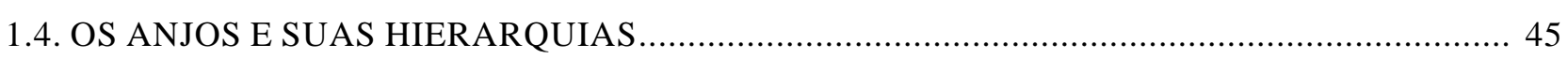

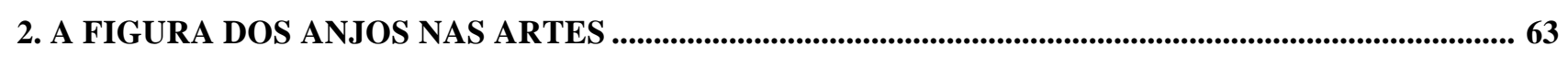

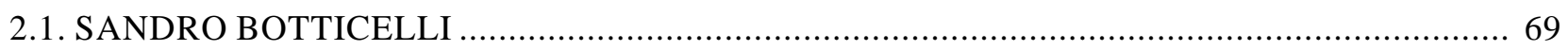

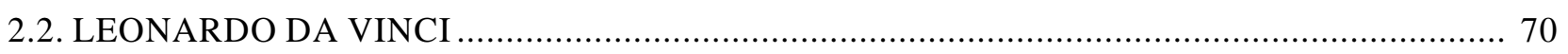

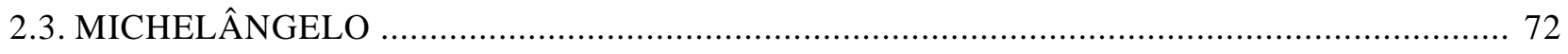

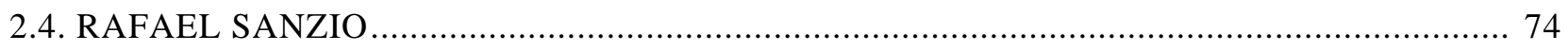

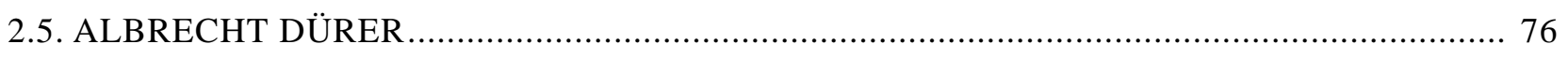

2.6. O BARROCO BRASILEIRO: OS ANJOS DE ALEIJADINHO E MESTRE ATAÍDE.............. 78

2.7. A PARTIR DE PAUL KLEE: OS ANJOS NA ARTE MODERNA ......................................... 80

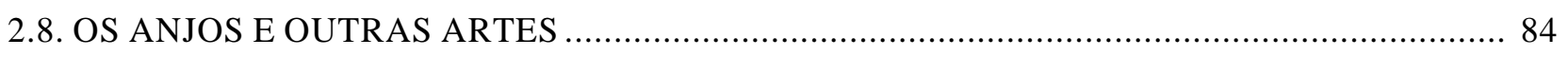

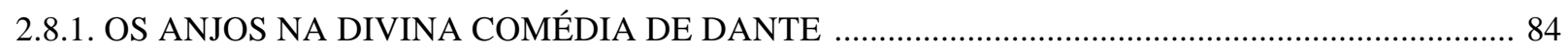

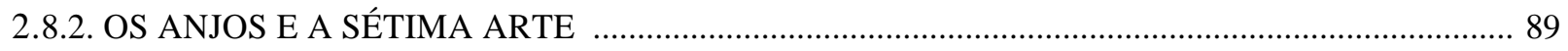

2.8.3. A POLÊMICA DE “ANGELS IN AMÉRICA” ........................................................... 94

3. O ANJO: UM MITO EM CONSTANTE TRANSFORMAÇÃO............................................................ 101

3.1. O ANJO E SEUS ARQUÉTIPOS ............................................................................... 104

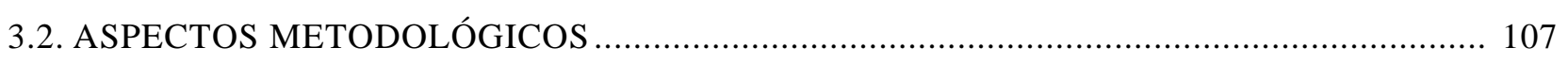

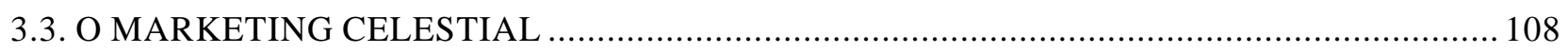

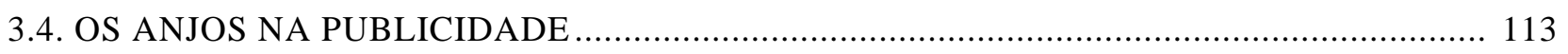

3.4.1. ANJOS COMO PORTADORES DE PROTEÇÃO E SEGURANÇA ………….............................. 113

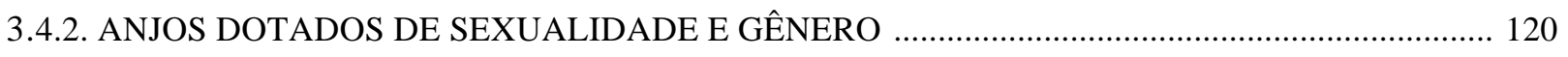

3.4.3. OS ANJOS, SEUS ASPECTOS FÍSICOS E AS CARACTERÍSTICAS MUNDANAS ...... 131

3.4.4. OS ANJOS E AS FRASES E EXPRESSÕES QUE OS CONTEMPLAM ........................................ 141

3.4.5. OS ANJOS E SUAS CARACTERÍSTICAS ADVERSAS E ANTAGÔNICAS .............................. 144

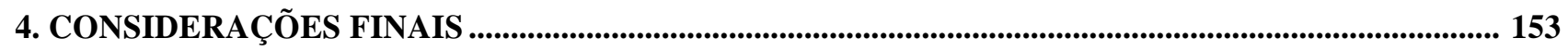

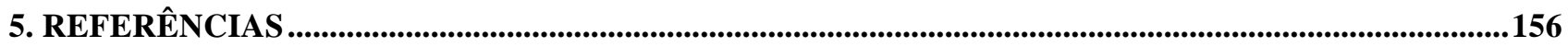




\section{INTRODUÇÃO}

Pensar em símbolos é habilidade inata dos seres humanos e que acaba derivando de tudo o que hoje relacionamos às representações. Muitos destes mundos imaginados foram elaborados por intelectuais da Idade Média e do Renascimento através de requintados sistemas simbólicos, nos quais uma simples palavra pode despertar uma infinidade de conceitos de acordo com o nível de repertório e, principalmente, com a experiência de vida

dos interpretantes. É por isso que os símbolos possuem ainda hoje uma aura de mistério e magia, que se não fosse desta forma, faria com que a mente humana convivesse com algo muito simplista, ou seja, as palavras acabam por produzir uma densidade semântica e emocional pelo simbolismo que carregam.

Apesar da existência de símbolos que são inventados deliberadamente, o que fascina o mundo e as pessoas são aqueles que, com o passar do tempo, acabaram por acumular significados numa complexa interação com os indivíduos. E o que os torna ainda mais fascinantes é que estão relacionados a sistemas de crenças e culturas que perduram durante séculos.

Neste ponto é que nos questionamos: Anjo: mito ou símbolo? Não que seja possível desassociá-los, porém é importante que possamos compreender a importância do símbolo, isto porque:

\footnotetext{
“(...) os símbolos aludem a conceitos mais profundos, dificeis de traduzir em palavras. Seus significados são construídos durante séculos, muitas vezes por culturas diferentes. Como se fossem uma linguagem alternativa, eles insinuam aquilo que os olhos não veem - aspirações, desejos, medos $e$ outros conceitos insondáveis, como divindade, alma, fé, imortalidade, inocência, beleza, pureza e transcendência” (FONTANA, 2012, p. 11)
}

Símbolos religiosos como os anjos, a cruz do Cristianismo, a lua crescente do Islã, a menorá do Judaísmo, entre outros, tornam-se sagrados não somente por sua utilização, mas sim por todo o poder de comunicação intrínseco que possuem para transmissão de conceitos importantes.

Muitos associam à mitologia muito mais por seus aspectos dramáticos ou históricos, sem perceber que na realidade, os grandes mitos e lendas mundiais, principalmente aqueles associados ao Egito e à Grécia antigos, possuem extraordinárias referências simbólicas e que permitem abrir caminho para o inconsciente pessoal e o coletivo, o que nos 
permitirá em capítulo posterior dissertar sobre os arquétipos de Carl Jung e sua associação aos mitos.

Abordar anjos como objeto de estudo torna-se tarefa delicada, justamente por não serem estes seres celestiais alados fisicamente representados, de maneira a permitir experiências sensoriais, com os quais possamos interagir com o mundo a nossa volta. A falta de comprovação científica de sua evidenciação traz para disciplinas como a Angelologia, um caráter de pseudociência, deixando-a muito à margem de postulados científicos. Por esta razão, este trabalho irá fundamentar-se na Antropologia para estruturar-se, tendo como norte a figura do anjo como sendo um ser construído culturalmente.

O discurso que estuda os anjos atualmente está mais próximo da fé e da teologia, aspecto este completamente aceitável, visto que a associação primária que se tem do tema é justamente a de cunho religioso, porém, é permitido estudá-lo sim como ciência, a partir do momento em que fé e razão se contrapõem.

Para tal compreensão, faz-se necessário, além da conceituação do termo, o entendimento das partes que o compõem, além disso, torna-se primordial um resgate histórico-cultural de sua representatividade na sociedade antiga e atual, analisando todas as possíveis implicações que sua existência como objeto de estudo pode trazer. Há sim, ao longo dos séculos, pensamentos científicos formulados a seu respeito, em especial na Filosofia, História da Arte e Teologia, sendo que nesta última, a religião mais influente para o corpus é o Cristianismo, que de certa maneira nos auxiliará no entendimento da especificidade do tema como manifestação artística-cultural.

Desde o Mundo Antigo, os homens já acreditavam em figuras míticas e simbólicas como mensageiras divinas e que poderiam intervir positivamente em sua vida. Tal apelo pode ser facilmente compreendido em função do quão reconfortante é crer na existência de seres espirituais, que possam vir em nosso auxílio em momentos de incertezas e necessidades.

Em um passado longínquo, já havia processos de produção artística e religiosa que foram e devem ser observados e analisados do ponto de vista estético, visto que o que antes era apenas estudado e categorizado como algo belo ou não, e que posteriormente foram denominados por Emmanuel Kant como Juízo Estético - na obra "Crítica da Razão Pura" onde o belo poderia ser algo subjetivo, nos faz pensar que de certa forma, nosso gosto e nossas opções estão relacionados à diversidade da cultura em que estamos inseridos, o que nos faz acreditar que seja inviável definir qualidades absolutas às obras de arte ou quaisquer 
produções artísticas na atualidade, isto porque tal análise depende também do contexto, temporalidade, bem como a circunstância em que foram ou estão inseridas tais obras.

É certo que a figura do anjo também se modernizou, tornou-se contemporânea e busca querer aproximar-se ao que de fato o comportamento dos seres humanos representa, permitindo um espelhamento e por que não dizer uma reflexão. No entanto, o que se percebe ao empregá-los a peças publicitárias é justamente uma maneira por vezes provocativa como forma de testar o entendimento de quem os vê, para que se verifique aqui a importância de um vasto repertório intelectual e até mesmo a que ponto a religião e as crenças permeiam a vivência dos seres humanos.

Durante séculos, a humanidade buscou na figura do anjo o que este sempre simbolizou: proteção, cuidado e conforto, no entanto atualmente, acabaram tão mergulhados e inseridos no comportamento humano, que se tornaram o seu mais fiel reflexo, inclusive no lado mais mundano e proibido.

A inquietação desta pesquisa surge da regularidade e da constância com que a figura do anjo tem sido representada imageticamente como recurso publicitário, buscando executar investigação de sua origem como ser culturalmente construído e de que forma vem sendo retratado na contemporaneidade. Tendo como eixo principal a personificação do anjo em imagens, aproximando-se da simbologia como forma de investigar sua sobrevivência através dos séculos. Apesar de não se tratar de um estudo aprofundado historicamente, busca identificar relações da figura do anjo com a arte e a presença deste no imaginário simbólico da sociedade, que continua utilizando-o no papel de sua função primeira como mensageiro de Deus.

Outra interpelação surge sobre a simbologia do anjo, visto que no período que antecede o século XVII sua utilização configurava como objeto de extrema força e poder. Desde então, sua concepção como figura imagética tem sofrido inúmeras modificações como forma de aproximação do comportamento humano.

Como objetivo principal, esta pesquisa propõe investigar os câmbios estéticos ocorridos na figura do anjo no decorrer do tempo, resgatando a origem de seu conceito, seu emprego na mitologia, bem como o levantamento dos principais estudiosos desde a Antiguidade até os dias atuais.

Como finalidades específicas, buscaremos averiguar quais as características físicas e psicológicas atribuídas aos anjos quando estes seres mitológicos são utilizados em peças publicitárias com intuitos mercadológicos, bem como identificar se há distinção na 
estética adotada nos anúncios em função das características distintas dos diferentes meios de comunicação. E por fim, associar o anjo como metáfora da modernidade, relacionando seu surgimento na arte contemporânea como reflexo da sociedade atual.

Trata-se de pesquisa qualitativa e exploratória na linha de Teoria e Pesquisa em Comunicação, cujo método utilizado teve como base referências bibliográficas que abordassem o objeto de estudo como tema.

O procedimento teórico-metodológico utilizou como suporte referencial anúncios e campanhas publicitárias coletados de meios impressos e internet, que tivessem em seu teor a figura do anjo ou qualquer tipo de alusão a este.

Este trabalho, portanto, busca compreender um pouco mais como os anjos surgiram, como sua figura midiática foi transformando-se no decorrer dos séculos, firmando características bem específicas de acordo com o seu pertencimento no tempo. Pelas razões já descritas, esta pesquisa buscou elucidar quais as contribuições possíveis para o conhecimento científico, mais precisamente nas áreas de Comunicação e da Estética, com base no estudo de produções midiáticas da figura do anjo na publicidade. Acreditamos que o mito do anjo possua relações com as áreas de estudo em questão, visto que nos permite fazer analogias a estas, através da fundamentação do objeto de estudo, cujo significado primário é "mensageiro", sua função básica e essencial do processo de envio de mensagens, além é claro do estudo mitológico, simbólico e arquetípico, que recebe de suas audiências, reações bem específicas e diferenciadas. 


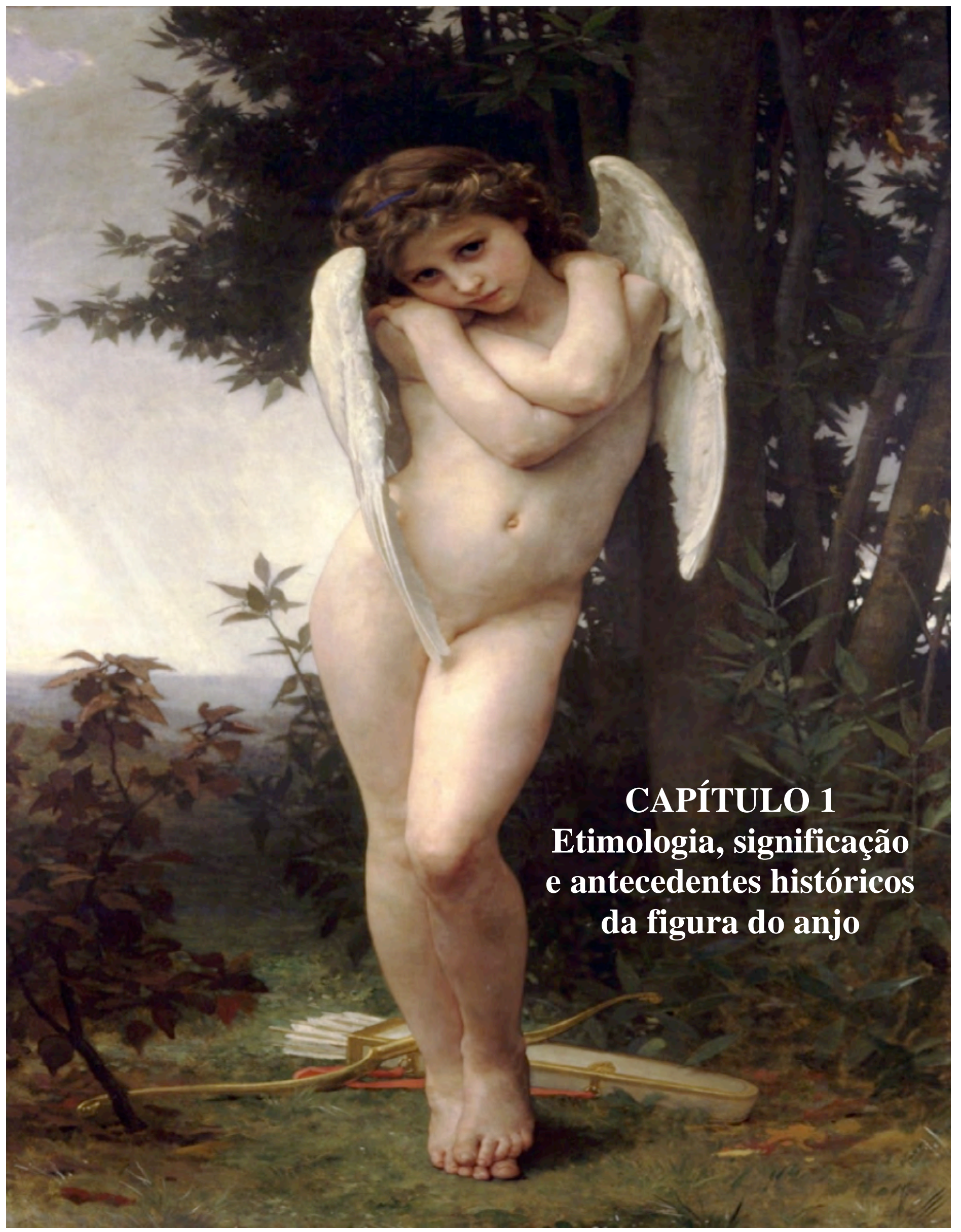




\section{CAPÍTULO 1}

\section{Etimologia, significação e antecedentes históricos da figura do anjo}

Em hebraico, a palavra usada para definir anjo é mal'ach (מלאך), já no latim é

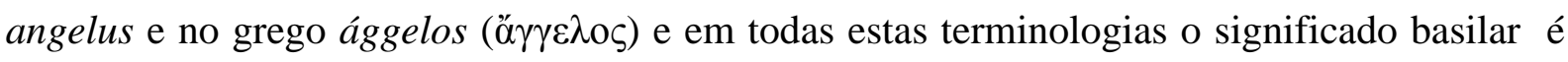
sempre o mesmo: o de mensageiro, independente se o termo empregado refere-se a mensageiros humanos ou a seres alados celestiais. "Para os teólogos cristãos, a palavra aponta para a função primordial dos mesmos que é comunicar mensagens divinas aos seres humanos”. (ERICKSON, 1997, p.194).

Ainda segundo o Manual de Etimologia do Português (VIARO, 2004), a palavra evangelho vem do latim medieval evangelium cuja significação é de "boa nova" e que deriva da palavra-raiz ággelos, podemos compreender melhor através do quadro sinótico abaixo:

angel - "mensageiro" (ággelos), sem etimologia definida

Ângelo < ággel.o.s, via latim angel.u.s, "anjo"

anjo < ággel.o.s, "mensageiro", via latim angel.u.s

angelical $<$ angel.ic.al.i.s

evangelho < latim medieval ev.angel.i.u.m, do grego eu.aggél.i.o.n, "boa nova"

Fonte: Manual de etimologia do português

Considerados "seres intermediários tradicionais entre Deus e a humanidade. Eles são definidos por sua função de proclamação de mensagem, embora este papel não compreenda todas as suas atividades.”(LEWIS, 1999, p. XVI), os anjos são onipresentes, estão em toda parte e a nossa volta. Durante séculos instigaram o imaginário coletivo sendo denominados nossos guardiões, que além de nos proteger e nos aconselhar, possuem como função prevalecente a de mensageiros, responsáveis por nos trazer notícias. Foram estes seres alados celestiais que, segundo a Bíblia, trouxeram a mensagem mais importante aos cristãos, o nascimento de Jesus Cristo. “Como mensageiros de Deus (...), os anjos são particularmente característicos da grande fé monoteísta do Ocidente. Isso acontece porque, nos sistemas politeístas, deuses e deusas geralmente aparecem em pessoa para entregar mensagens." (LEWIS, 1999, p. XVII). Seriam segundo citações encontradas no Dicionário de Símbolos: 


\begin{abstract}
"Seres intermediários entre Deus e o mundo, mencionados sob formas diversas nos textos acádios, ugaritas, bíblicos e outros. Seriam seres puramente espirituais, ou espíritos dotados de um corpo etéreo, aéreo; mas não poderiam revestir dos homens senão as aparências." (CHEVALIER, 1994, p.60)
\end{abstract}

Alguns, inclusive, atribuem-lhes o ar angelical em função de certas iconografias que os retratam como sendo loiros e de olhos azuis, o que Jesse Hurlbut em seu livro História da igreja cristã, atribui tal feito ao seguinte acontecimento:

“(...) É acerca de Gregório I, que se conta a conhecida história de que, ao ver alguns escravos em Roma, de cabelos louros e olhos azuis, perguntou quem eram. Disseram-lhe, então, que eram "angli", isto é, "ingleses", ao que ele respondeu: "Non angli, sed angeli", quer dizer, não ingleses, mas anjos.” (HURLBUT, 1979, pág. 100)

Os teólogos assim como os artistas, escultores e escritores, se esforçaram em buscar uma maneira de unir o mundo terreno ao celeste. Como imaginar e contemplar esses seres divinos que não fazem parte do nosso mundo? Será que o fato de anjos terem asas reflete o nosso próprio desejo de voar?

São constantemente retratados como seres alados, os quais "as asas são antes de mais nada, símbolo de alçar voo, do alijamento de um peso (leveza espiritual, alívio), de desmaterialização, de liberação - seja de alma ou de espírito - de passagem ao corpo sutil.” (CHEVALIER, 1994, p.61) e portanto “as asas exprimirão geralmente uma elevação ao sublime, um impulso para transcender a condição humana. Constituem o atributo mais característico do ser divinizado (...).” (CHEVALIER, 1994, p.91).

Depois das asas, a segunda característica mais retratada são as auréolas. Uma coroa de luz circular alocada próximo à cabeça, que simboliza santidade. Uma maneira conveniente que os artistas encontraram para chamarem a atenção para a divindade dos anjos e dessa forma distingui-los dos humanos. Na Bíblia, os anjos foram criados quando a luz foi criada, no alvorecer da criação. Assim, as auréolas criam uma "imagem solar que possui o sentido de coroa. (...) Essa irradiação de origem solar indica o sagrado, a santidade, o divino.” (CHEVALIER, 1994, p.100) e é assim encarada como um:

“(...) procedimento de uso universal para valorizar um personagem naquilo que ele tem de mais nobre: a cabeça. Graças à auréola, a cabeça é, por assim dizer, engrandecida; ela irradia. No homem aureolado, a parte superior - celeste e espiritual - assumiu a preponderância: é o homem realizado, unificado pelo alto." (CHAMPEAUX, 1935, p. 270) 
O apelo dos anjos parece ser fácil de compreensão em um mundo repleto de revoluções, mudanças e incertezas, pois acaba sendo profundamente reconfortante crer na existência de seres espirituais cuja principal atribuição é a proteção e o encorajamento. Originários do Zoroastrismo, são particularmente encontrados em religiões como Judaísmo, Cristianismo e Islamismo "em que Deus é concebido como um ser tão elevado que não intervém diretamente no mundo. Os anjos são constantemente vistos entregando mensagens aos mortais e anunciando de outras maneiras a vontade de Deus.” (LEWIS, 1999, p. XVI) e por essa razão:

\footnotetext{
"Outros, ainda, veem nos anjos símbolos das funções divinas, símbolos das relações de Deus com as criaturas, ou, ao contrário (mas os opostos coincidem na simbólica), símbolos de funções humanas sublimadas ou de aspirações insatisfeitas e impossíveis. (...) de modo ainda mais amplo, o anjo simboliza a criatura na qual surge já realizada a transformação do visível em invisível por nós executada." (CHEVALIER, 1994, p.60)
}

Desta forma, é possível afirmar que os anjos acabam por enfatizar não a sua importância, mas sim a glória de Deus, visto que aparecem bruscamente, realizam seu trabalho e desaparecem com a mesma rapidez com que surgiram e que "são particularmente característicos da grande fé monoteísta do Ocidente. Isso acontece porque, nos sistemas politeístas, deuses e deusas geralmente aparecem em pessoa para entregar mensagens" (LEWIS, 1999, p. XVII)

O Zoroastrismo ${ }^{1}$ foi considerada a primeira religião a se utilizar dos anjos, pois apesar da dificuldade em reconstruir a origem das mensagens de Zaratrusta, ao que parece, buscou-se não a criação de uma nova religião, mas sim a reforma da já vigente, através da centralização de poder nas mãos do deus único, Ahura Mazda. Desta maneira, “as outras divindades do antigo panteão foram reduzidas ao status de meros agentes da deidade suprema - ou seja, ao status de anjos" (LEWIS, 1999, p. XVII).

\footnotetext{
${ }^{1}$ Religião que floresceu na Ásia Central em cerca de 1.000 a.C. (mais especificamente na Pérsia), fundada pelo profeta Zoroastro (também conhecido por Zaratrusta) que embora considere Ahura Mazda seu único deus, também apresenta um vasto conjunto de tradições relativas a outros seres, desde imortais benévolos até entidades demoníacas. Prevê que as forças do bem serão triunfantes no final (WILKINSON, 2012, p.168).
} 


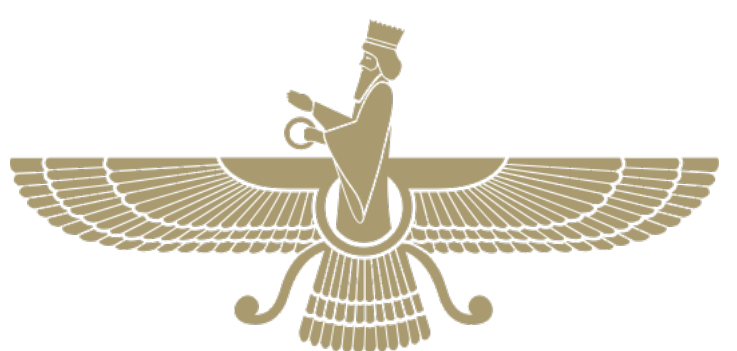

Figura 1: O Faravahar representação da alma humana. Um dos símbolos do zoroastrismo².

Igualmente, o Judaísmo também acabou ameaçado pelo destaque demasiado sobre os anjos, visto que estes seres celestiais serviam a Jeová desde suas primeiras narrativas bíblicas e isso muito antes que as doutrinas religiosas dos persas pudessem exercer influência sobre esta religião. Nas Escrituras hebraicas, os anjos devem levar mensagens, proteger e também destruir, além é claro de oferecer constantemente louvores a Jeová. É somente nos livros finais das Escrituras hebraicas, ou seja, o Velho Testamento cristão, que os anjos iniciam novas funções diversas daquelas que simplesmente adoravam a Deus e executavam suas ordens, por exemplo no livro do Profeta Zacarias, um anjo intercede perante Deus em favor de Israel:

"Então o anjo do Senhor respondeu, e disse: Ó Senhor dos Exércitos, até
quando não terás compaixão de Jerusalém, e das cidades de Judá, contra as
quais estiveste irado estes setenta anos? E respondeu o Senhor ao anjo, que
falava comigo, com palavras boas, palavras consoladoras" (ZACARIAS
1:12-13)

Além da Bíblia hebraica, outros textos religiosos importantes também dissertaram sobre a existência dos anjos. O mais importante deles foi o Talmude ${ }^{3}$, em que os rabinos talmúdicos, enquanto buscavam abrandar o que acreditavam ser uma ênfase demasiada sobre os anjos, simultaneamente acabaram reconhecendo inovações pós-bíblicas que surgiram, como por exemplo a divisão entre anjos de paz e anjos do mal.

\footnotetext{
${ }^{2}$ Disponível em: <http://althistory.wikia.com/wiki/File:2000px-Faravahar-Gold.png> Acesso em: 05 de fevereiro de 2014

${ }^{3}$ O Talmude (em hebraico: תִתמוּ, ou Talmud) é um livro Sagrado dos judeus um registro das discussões rabínicas que pertencem à lei, ética, costumes e história do judaísmo. É um texto central para o judaísmo rabínico.
} 


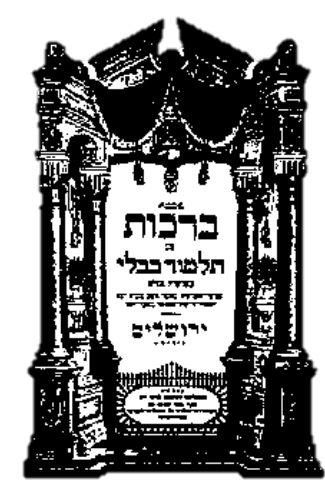

Figura 2: Talmude - Livro sagrado dos Judaísmo ${ }^{4}$.

Os anjos do Judaísmo foram herdados pelo Cristianismo, outra doutrina monoteísta. Acabaram tornando-se tão importantes que alguns concílios da Igreja Católica, surgidos bem mais tarde, temiam que a devoção exacerbada aos anjos acabassem encobrindo a devoção a Deus. Ao surgir, a doutrina cristã não aceitou instantaneamente estes seres celestiais, questionando se os anjos deveriam mesmo ser parte da doutrina por eles pregada. Tanto que São Paulo não favoreceu a veneração de anjos, porém anos mais tarde, em 325 d.C. o:

"Concílio de Nicéia ${ }^{5}$ decretou que a fé nos anjos fizesse parte do dogma da Igreja. Apenas dezoito anos depois, no Sínodo de Laudicéia, o culto (veneração, devoção, honra) dos anjos foi declarado idólatra. Quatro séculos e meio mais tarde, em 787, o Sétimo Sínodo Ecumênico restabeleceu o culto dos anjos, com certas limitações" (LEWIS, 1999, p. 105).

Outra grande religião monoteísta que também convive com a presença dos anjos é o Islamismo, religião fundada pelo profeta Maomé em 622 d.C. e que usa para designar os anjos o termo Mala’ika, também mensageiro. No livro sagrado do Islamismo, o Alcorão, anjos são mencionados frequentemente. Alguns deles também são encontrados no Judaísmo e Cristianismo, como é o caso de Djibril (Gabriel) e Micail (Miguel).

Em outras religiões desempenharam papéis fundamentais desencadeando e provocando discussões e debates durante séculos, justamente por estarem culturalmente enraizados em civilizações antigas. No entanto, a crença em sua existência também acabou por permitir o surgimento de novas religiões e credos devotados exclusivamente a estes seres alados. Surgem em eventos fundamentais da Bíblia, como por exemplo quando o anjo Gabriel

\footnotetext{
${ }^{4}$ Disponível em: <http://upload.wikimedia.org/wikipedia/commons/thumb/2/28/Talmud.jpg/220px-Talmud.jpg > Acesso em: 10 de março de 2014

${ }^{5}$ O Primeiro Concílio de Nicéia foi um concílio de bispos cristãos reunidos na cidade de Nicéia (atual İznik na Turquia), pelo imperador romano Constantino I em 325 d.C. O concílio foi a primeira tentativa de obter um consenso da igreja através de uma assembleia representando toda a cristandade.
} 
leva a mensagem do nascimento de Jesus a Maria, porém não estão restritos apenas a esta função e ao Cristianismo, podendo ser encontrados também em outras culturas e religiões.

Apesar de serem mensageiros de Deus e claramente habitantes da fé monoteísta, não é algo insensato buscar outros seres semelhantes a estes em religiões não-monoteístas. $\mathrm{Na}$ contemporaneidade, é possível encontrar estudiosos que "geralmente mencionam certos espíritos e semideuses hindus/budistas, como os devas, apsaras e gandharvas, bem como divindades mensageiras do panteão grego ou romano clássico, como Eros, Hermes e Nice” (LEWIS, 1999, p. XX).

Há na Antiguidade, mais especificamente nas religiões panteístas do Mediterrâneo e do Oriente Médio, inúmeros deuses e semideuses e por que não dizer, até divindades menores cuja função era a de mensageiros divinos. Muitos destes seres alados forneceram mais tarde os paradigmas para anjos futuros.

Seres alados são reportados na história no mundo desde o surgimento do continente mais antigo que temos notícia, o africano. Podemos até dizer que a civilização africana seria a responsável pela origem dos mitos, visto que nossos ancestrais mais longínquos habitaram essa região. A diversidade cultural desse continente é tanta que nada fica a dever para qualquer outra nação do mundo, em um mesmo continente temos ainda hoje populações rurais, tribos nômades, onde antes habitaram grandes faraós e reis de impérios como o Egito. Tais divergentes aspectos é que nos impossibilitam de efetuar qualquer tipo de generalização em relação à cultura ou mitologia africana, pois cada tribo possui suas próprias crenças regionais, no entanto, no teor destas mitologias distintas, é possível identificar temas comuns.

O que geralmente se nota é que apesar de incorporarem divindades distintas em sua mitologia, ainda assim existe sempre a homenagem a um deus maior, que pode ser identificada como um criador, um ancestral masculino ou feminino, até um ancião tribal. Tal deus supremo é o responsável por explicar praticamente tudo, de um efeito ou catástrofe natural até a existência da morte e isso se dá através do poder da onisciência, no qual não é comum retratá-los com olhos bem abertos, leitura de pensamentos e sabedoria holística. Atualmente, o continente africano vem sofrendo mutações em seu contexto religioso-cultural, visto que muitos povos e tribos têm abraçado o Islamismo e o Cristianismo. 


\subsection{Os seres alados da mitologia egípcia}

Não é possível dissertar sobre anjos sem antes identificar na mitologia complexa do Egito Antigo, seres alados que dirigiam todos os aspectos da vida das pessoas.

Os povos egípcios da Antiguidade eram fervorosos adoradores de deuses e deusas, que influenciavam desde a cheia do Rio Nilo até nascimentos e mortes. A arte egípcia, cerca de cinco mil anos atrás, associava as mudanças do tempo, principalmente transformações terrenas, como as cheias do rio Nilo, as pestes da lavoura e o comportamento humano aos deuses ou como próprio ser divino, como era assim considerada, a figura do faraó. E, em homenagens a estes reis, acabaram por enterrar "objetos e imagens que substituíam os servos e o tesouro daqueles mais poderosos, e acreditavam que estes serviriam à alma em outro plano” (GOMBRICH, 1999).

Posteriormente, com a realização de escavações feitas por arqueólogos renomados por volta de 1800, muitas dessas relíquias foram encontradas e assim estudadas suas significações.

Dentre esses seres mitológicos, é possível notar divindades aladas que seriam os precursores dos anjos, a começar pelo que eles consideravam como sendo a própria alma. Os antigos egípcios acreditavam que a alma humana era composta de cinco partes: a Ren, o $B a$, o $K a$, o Sheut, e o $I b$. Para eles $B a$ era tudo o que faz um indivíduo único, algo similar à noção de "personalidade". Representado como um ser alado com corpo e asas de gavião e a cabeça do morto, na hora do falecimento, acreditava-se que $B a$ alçava voo separando-se de seu corpo.

No Egito Antigo, as:

“(...) representações simbólicas da alma são tão numerosas quanto as crenças que sobre ela existem. Por breve que seja, uma noção a respeito dessas crenças torna-se indispensável ao entendimento dos símbolos. Entre os egípcios, por exemplo, a íbis-sagrada representa o princípio imortal (Akn), de natureza celeste, brilhante e poderosa ao mesmo tempo que parece comum aos homens e aos deuses; a ave com cabeça humana corresponde ao espírito próprio de cada indivíduo (Ba) que pode vagar após a morte pelos lugares antes frequentados pelo defunto." (CHEVALIER, 1994, p.31) 


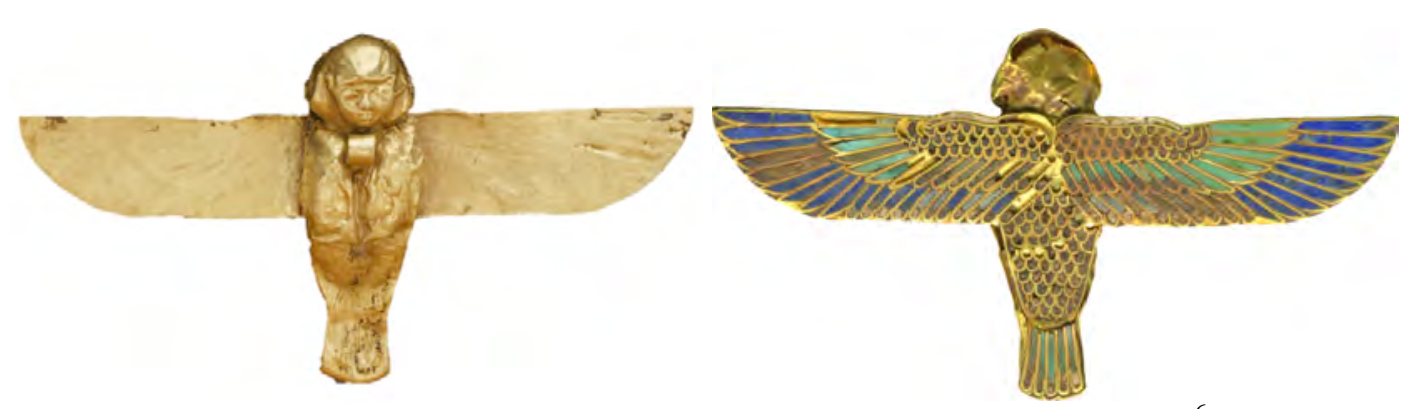

Figura 3 - Amuleto egípcio em ouro - Deus Bá - Walters Art Museum ${ }^{6}$

Sendo assim:

“O $\mathrm{Ba}$, portanto, é um princípio espiritual que pode aparecer independentemente de seu suporte físico, agir por sua própria conta, representar de certo modo seu dono (...) alma itinerante de um ser vivo, capaz de ação material." (CHEVALIER, 1994, p.32)

Muitos desses deuses alados já eram considerados mutantes, pois por vezes assumiam formas animais em distintas ocasiões. É o caso do deus-sol Rá, considerado o principal representante da mitologia egípcia. Tido como protetor dos faraós e de seus exércitos em batalhas, acreditava-se que assumia várias formas, desde o escaravelho Khepri (imitando um besouro empurrando uma bola de esterco pelo chão, remetia à ideia de empurrar o Sol pelo céu da mesma maneira), a águia Rá-Harakhty ou Amon-Rá, considerado o rei dos deuses. O faraó Tutancâmon (século XIV a.C.) identificava-se profundamente com Rá, pois muitos dos objetos encontrados em sua tumba eram adornos que simbolizavam esse deus, como podemos ver nas figuras que seguem:

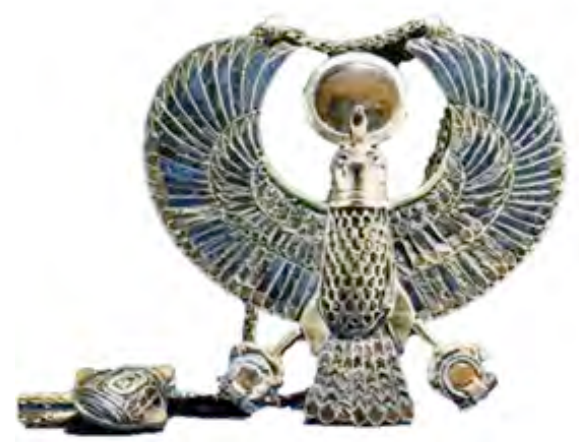

Figura 4: Joia para ornamentação peitoral representando Ra-Harakhty - Exposição Egípcia Rei Tutancâmon ${ }^{7}$

\footnotetext{
${ }^{6}$ Disponível em: <http://art.thewalters.org/detail/14425/ba-bird/> Acesso em 12 de março de 2014

${ }^{7}$ Disponível em <http://www.touregypt.net/museum/pendant1page.htm> Acesso em 06 de abril de 2014
} 

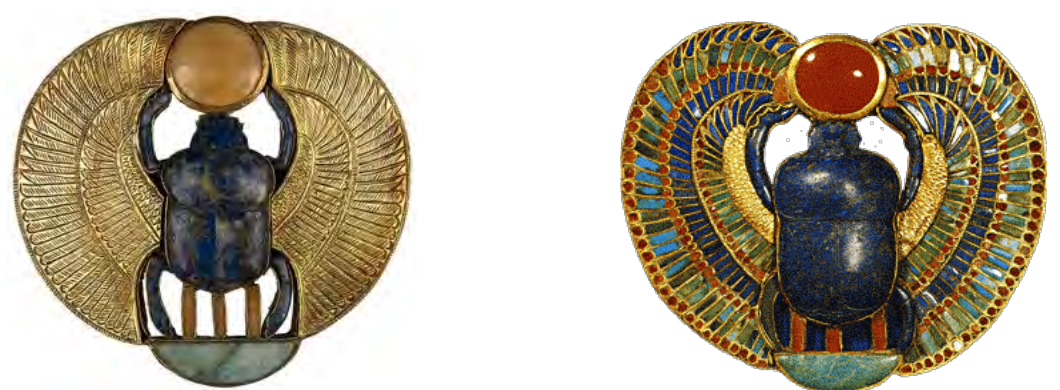

Figura 5: Joia peitoral (broche) de Tutancâmon com escaravelho (besouro) alado - Egyptian Museum - Cairo ${ }^{8}$

Podemos ainda citar, dentre estes mitos egípcios, a deusa $M a$ 'at, que representava a verdade e além disso, julgava todas as almas que chegavam à Morada dos Mortos. Esta divindade alada era comumente retratada graficamente no Império Antigo (2680-2190 a.C.) como uma mulher jovem, com vestes longas, sentada sobre os calcanhares ou em pé, com asas e uma pena de avestruz na cabeça, segurando um cetro, símbolo do poder, em uma mão e um $A n k h^{9}$, símbolo da vida eterna, na outra. Estas imagens são comumente encontradas nos sarcófagos como um símbolo de proteção para a alma dos mortos.
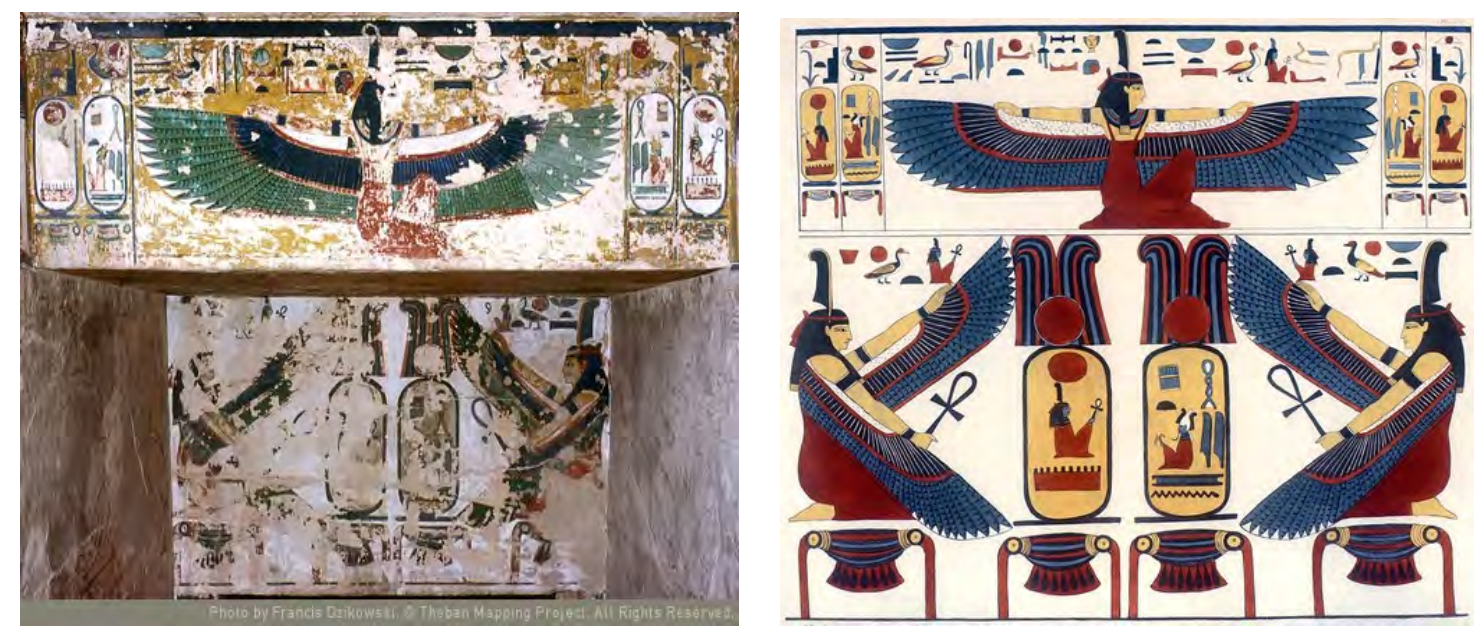

Figura 6: Figura da deusa Ma'at alada ajoelhada e ladeada por cartelas de Seti I - Imagem original e restaurada ${ }^{10}$.

Muitos são as deusas e deuses egípcios retratados com asas, tanto que por vezes torna-se tarefa difícil discernir qual a iconografia correta, pois a estética adotada torna-se muito similar inclusive nas cores. A divindade Mut, considerada deusa-mãe de Tebas, era representada pelos antigos egípcios como um abutre, pois estes acreditavam que para ser uma

\footnotetext{
${ }^{8}$ Disponível em <http://www.globalegyptianmuseum.org/detail.aspx?id=14836> Acesso em 06 de abril de 2014

${ }^{9}$ Conhecida também como cruz ansada, era na escrita hieroglífica egípcia o símbolo da vida. Conhecida também como símbolo da vida eterna, os egípcios usavam-na para indicar a vida após a morte. A forma do ankh assemelha-se a uma cruz, com a haste superior vertical substituída por uma alça ovalada.

${ }^{10}$ Disponível em <http://www.thebanmappingproject.com> Acesso em 06/04/2014
} 
boa mãe protegendo e alimentando seus filhos, o abutre seria o animal que melhor representaria tal dedicação. Mut foi descrita e retratada como uma mulher alada, porém com as asas de um abutre e segurando um ankh, trazendo a coroa unida do Alto e Baixo Egito, e um vestido vermelho ou azul.

Já a deusa do céu, Nut, era representada com suas asas protetoras sempre abertas. Em sua cabeça foram inseridos chifres de vaca e um disco solar, que são elementos comumente utilizados nas representações de várias deusas egípcias.
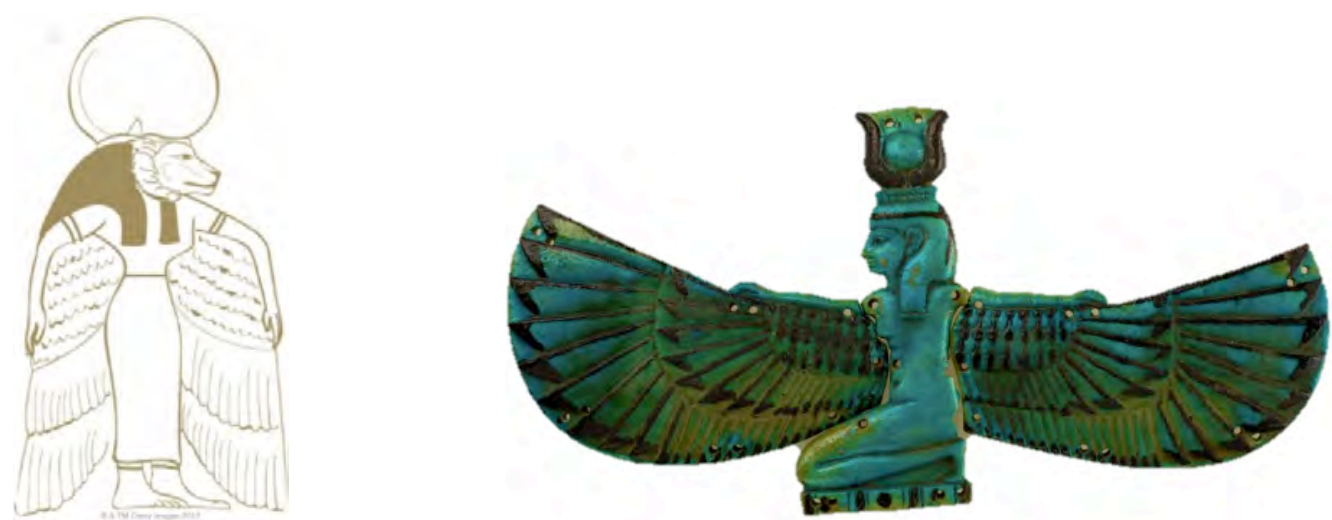

Figuras 7 e 8: Representação gráfica da deusa $M u t^{11}$ - Livro Mitos e Lendas - Philip Wilkinson e joia peitoral (broche ) da deusa $\mathrm{Nut}^{12}$ - The Metropolitan Museum de Art - New York

Além de todos esses deuses e deusas alados, "lendas tardias assimilaram a lenda de Alcíone à de Ísis; a mulher voa através dos ares e por cima dos mares, em busca de seu marido, filho do Astro da manhã, como Osíris era o sol-levante." (CHEVALIER, 1994, p.28)

\subsection{O panteão dos deuses da mitologia Assíria e Suméria}

O continente asiático, além de ser o local do surgimento de algumas das primeiras cidades do mundo, foi participante também do desenvolvimento da escrita e das religiões organizadas e que deixaram registros importantes de seus numerosos mitos, os quais nesta dissertação, restringiremo-nos apenas aos relacionados às características aladas e de mensageiros divinos. Assim como no Antigo Egito, as instituições religiosas e políticas do

\footnotetext{
${ }^{11}$ Figura 7 - Disponível em: Livro Mitos \& Lendas - Philip Wilkinson - pág. 244 - Acesso em 06/04/2014

${ }^{12}$ Figura 8 - Disponível em: <http://www.metmuseum.org/Collections/search-thecollections $/ 552609$ ? rpp=20\&pg=1\&ao=on\&ft=wing \&deptids=10\&pos=5> Acesso em 06/04/2014
} 
Período Assírio também possuíam em seus sacerdotes figuras de extrema relevância e influência política, assim como os governantes permaneciam sendo vistos como figuras sagradas. E graças a estes cultos sacerdotes, que passaram a escrever em pequenas tabuletas de argila, é que hoje temos acesso a alguns mitos mais primitivos.

No Período Assírio, compreendido entre 1000 a 700 a.C., a arte era representada por deuses e cenas com a presença do rei em que:

"os palácios e templos do império Assírio eram adornados com baixosrelevos em pedra. Muitos deles mostravam criaturas míticas - como o touro alado aqui representado - vistos pelos assírios como guardiães que zelavam pelas construções, protegendo-as contra o mal” (WILKINSON, 2012, p. 148)
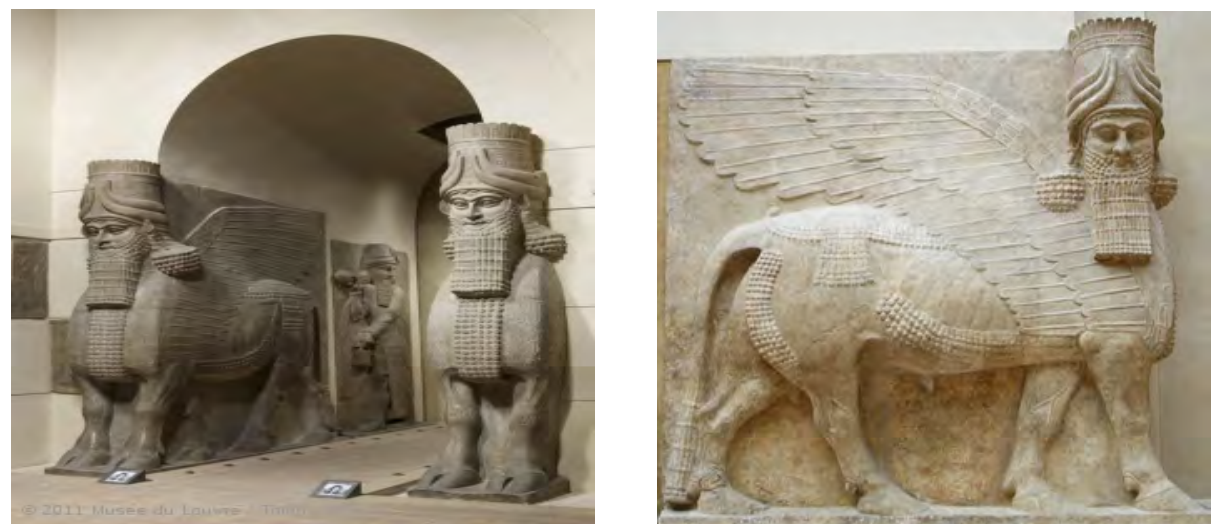

Figura 9: Baixo-relevo dos portões do palácio do rei Sargon II em Dur Sharrukin na Assíria - Museu do Louvre ${ }^{13}$

Estes seres protetores além de ficarem localizados nos portões dos palácios, tinham também como objetivo vigiar as pessoas protegendo-as contra os maus espíritos. É nessa época também, ainda na Mesopotâmia, cerca de mil anos antes de Cristo, que encontramos na mitologia suméria, a imagem de Pazuzu, rei dos demônios do vento e filho do deus Hanpa. Um demônio híbrido cujas funções míticas estavam associadas aos estragos da terra, no entanto, em determinados momentos apropriados, era visto também como protetor divino, pois sua feição horrenda tinha muitas vezes como intenção, repelir espíritos maldosos. Tal figura estética por si só já amedronta.

Frequentemente representado como uma criatura de corpo humano, porém com a cabeça de um leão ou de um cachorro, com um par de asas, garras, face assustadora e a seguinte inscrição nas costas: "Eu sou Pazuzu, filho de Hanpa, rei dos espíritos maus do ar,

\footnotetext{
${ }^{13}$ Disponível em: <http://www.louvre.fr/routes/les-palais-assyriens> Acesso em 14/04/2014
} 
que irrompe violentamente das montanhas, causando muito estrago" ${ }^{14}$ tinha também como propósito repelir outros espíritos do mal. Geralmente é apresentado com a mão direita levantada e a esquerda abaixada, representando vida e morte, criação e destruição.
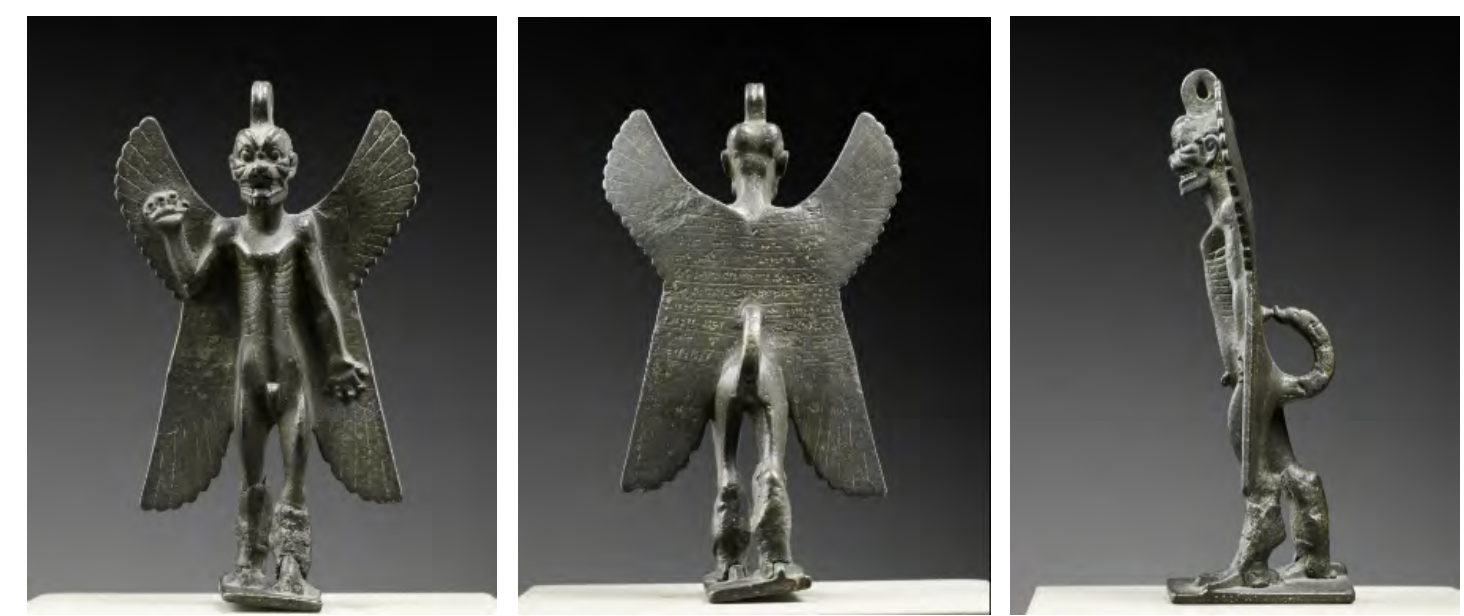

Figura 10: Estatueta do demônio assírio Pazuzu contendo inscrições - Museu do Louvre - Paris - França ${ }^{15}$

\subsection{Mitologia grega: A pedra fundamental dos mitos mundiais}

Na Europa Clássica, mais precisamente na Grécia e Roma antigas, os mitos e divindades trouxeram narrativas de toda a história mundial. A civilização grega atingiu seu ápice no século V a.C. e não tinha por base um império ou nação, mas sim várias cidadesestado, cada uma delas com suas próprias divindades, tradições e cultura, o que resultou no culto em locais específicos para certos deuses.

Atualmente nos é permitido notar a presença destas figuras mitológicas nas figuras helênicas e ocidentais, pois muitos de seus templos sobreviveram juntamente com os objetos ritualísticos e as imagens de culto por eles utilizadas. Além disso, escritores gregos descreveram rituais religiosos, como por exemplo a oferenda de alimentos e bebidas e até mesmo na chamada Guerra de Tróia, fazia-os crer que cada acontecimento desse conflito fora regido pela influência dos deuses.

Com o declínio da civilização grega, os mitos acabaram tomando formas diversas para sobreviver. Com a expansão do império romano, estes iam adotando as divindades locais

\footnotetext{
14 " Je suis Pazuzu, fils de Hanpa. Le roi des mauvais esprits des vents qui sort violemment des montagnes en faisant rage, c'est moi.." - texto original - Museu do Louvre - Paris. Fonte: http://www.louvre.fr/en/oeuvre-notices/statuette-demon-

pazuzu-inscription
${ }_{15}$ Disponível em: <http://www.louvre.fr/en/oeuvre-notices/statuette-demon-pazuzu-inscription> Acesso em 20/04/2014
} 
como seus deuses. Havia o interesse em especial pelos deuses e deusas da Grécia e com isso houve uma fusão da personalidade destes com as próprias divindades romanas para que se pudessem criar figuras muito similares, porém com sutis distinções, como por exemplo o deus romano do céu, Júpiter, que possui como equivalente Zeus na mitologia grega, porém o associavam mais especificamente à justiça e aos magistrados, enquanto para os gregos, este era o rei soberano de todo o cosmo.

Como já mencionado anteriormente, como mensageiros de Deus, os anjos são mais constantemente encontrados em religiões monoteístas, no entanto, é relevante ressaltar a existência de criaturas semelhantes a estes seres celestiais em religiões politeístas como o panteão grego e romano clássico, principalmente deidades como Eros, Hermes e Niké, já que estes contribuíram de maneira importante para a iconografia dos anjos posteriormente no Cristianismo. E para a compreensão dos primórdios desta iconografia, vale o estudo sobre cada um destes deuses alados, o qual iniciaremos por:

\subsubsection{Nice / Niké / Nique / Vitória}

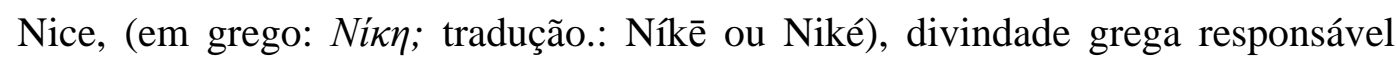
pela "personificação da Vitória, Nique é filha do Titã Palas e de Estige, consoante Hesíodo, pertencendo destarte à primeira geração divina, anterior aos deuses olímpicos. É iconograficamente representada com asas e dotada de incrivel velocidade." (BRANDÃO, 1991, Volume II, pág. 175)

Os gregos buscavam representar conceitos como paz, vingança e justiça como deusas em uma data muito precoce. E Nice/Niké foi uma dessas primeiras encarnações. Figura feminina portadora de enormes asas que lhe possibilitavam voar sobre a terra atribuindo notícias de vitória, fossem estas em competições atléticas ou em batalhas sangrentas. Precede os anjos, justamente pela sua função de mensageira, e por vezes utilizava um trompete para se fazer ouvir melhor.

Os romanos evidenciaram a deusa Vitória quando conquistaram o mundo grego, adotando-a imediatamente e adaptando-a como símbolo da dominação do mundo. Não raro é vê-la sendo representada em pé sobre um globo, coroando o imperador e empunhando um escudo com inscrições das glórias de Roma. Porém, não é esta a única maneira de sua 
representação. Mais comumente encontrada na arte grega, na qual é retratada de pé, vestindo túnica feminina com um cinto de segurança sob os seios e com uma dobra pendendo para os quadris.

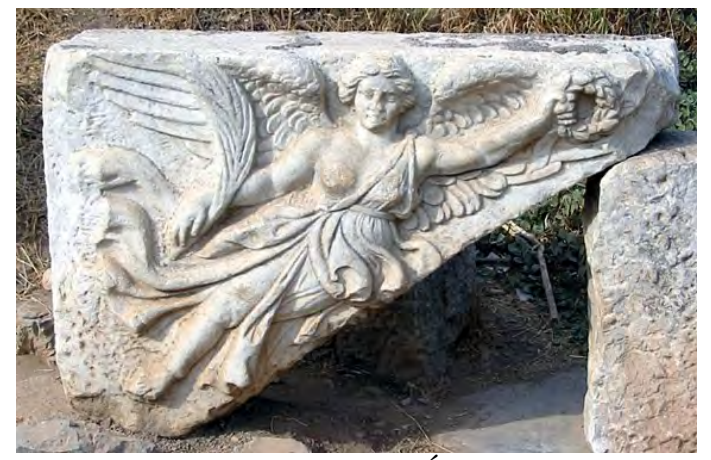

Figura 11: Baixo-relevo de Nice, deusa da vitória, em Éfeso, cidade greco-romana da Antiguidade ${ }^{16}$

Com o advento do Cristianismo vieram também os mensageiros de Deus. Surgiram segurando cruzes e estavam perto de Deus como representações de seu poder e glória. No entanto, embora os anjos devam boa parte de suas representações a Vitória grega e romana, sua imagem era bastante distinta.

Nas representações cristãs, os anjos surgiam com halo e vestidos em trajes mais masculinos típicos da Antiguidade, geralmente uma túnica longa, branca e larga, usando drapeado na diagonal no peito ou jogado sobre os ombros. Eles eram mensageiros alados que desciam do céu para anunciar a vontade de Deus para a humanidade.

Os anjos só começaram a surgir utilizando roupas mais femininas durante o período medieval tardio, quando seus mantos drapeados tornaram-se algo mais próximo de um vestido apertado de manga elegante e com uma cintura alta, fazendo com que assim começassem a se assemelhar mais as Vitórias gregas, embora seu contexto religioso cristão ficasse completamente claro quanto a sua identidade.

A deusa Niké, representante da vitória, ainda hoje é também tratada como uma figura extremamente decorativa, sendo que esta função de adorno surgiu na arte grega a partir do período arcaico (século VI a.C.) em diante. Encontrada de múltiplas maneiras, sejam estátuas, relevos, vasos, moedas ou estatuetas em terracota, demonstra que mesmo com o passar de tantos séculos, ainda permanece em constante evolução. A imagem mais famosa desta divindade alada é a de Samotrácia, exposta no Museu do Louvre, em Paris.

\footnotetext{
${ }^{16}$ Disponível em: <http://pt.wikipedia.org/wiki/Éfeso\#mediaviewer/Ficheiro:Niké_Éphèse.jpg> Acesso em: 19/04/14
} 


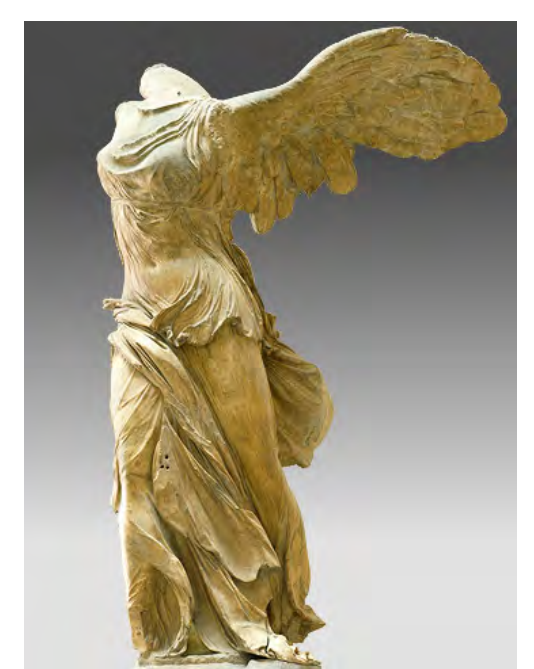

Figura 12: Estátua da deusa Vitória - cerca de 220-185 a. C. - Samotrácia - Museu do Louvre - Paris - França ${ }^{17}$

Além da Vitória de Samotrácia, é possível encontrar esta mensageira alada retratada pelos gregos e romanos e que até hoje nos permite compreender suas formas de representação. A deusa Niké aparece também no famoso Altar de Pérgamo, uma magnífica estrutura dedicada a Zeus, e que foi originalmente produzida no século II a.C. na cidade grega de Pérgamo. Esta construção sofreu muitas avarias e estava destruída. Ao final do século XIX, foi escavada de seu local original e teve partes remetidas para a Alemanha através de uma expedição liderada pelo arqueólogo Carl Humann. Hoje, tal altar encontra-se abrigado no Museu Pergamon em Berlim, que apesar de parcialmente destruído nos permite notar as asas atribuídas à deusa alada.

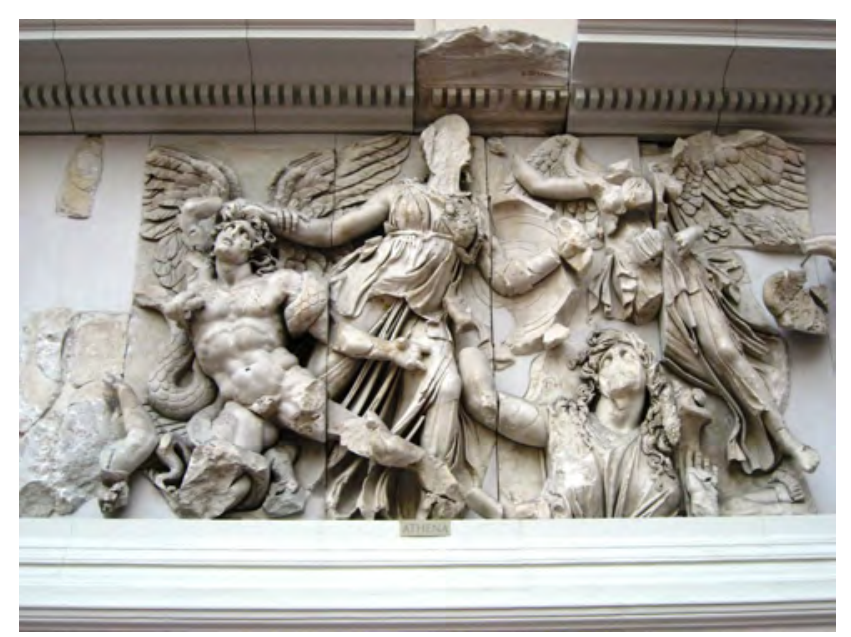

Figura 13: parte do friso "Gigantomaquia" - Altar de Pérgamo - Pergamon Museum - Berlim - Alemanha ${ }^{18}$

\footnotetext{
${ }^{17}$ Disponível em: <http://musee.louvre.fr/oal/victoiredesamothrace/victoiredesamothrace_acc_en.html\#seq_1> Acesso em 19/04/14

${ }^{18}$ Disponível em: <http://www.smb.museum/en/museums-and-institutions/pergamonmuseum/image-gallery.html> Acesso em 19/04/14
} 


\title{
1.3.2. Hermes / Mercúrio
}

Hermes é sem dúvida um dos mais relevantes precursores da concepção de anjos como mensageiros que possuímos na atualidade. Podemos considerá-lo como um dos seres mitológicos mais importantes e que certamente serviu de paradigma para nossos seres celestiais atuais. Suas características eram tão representativas que posteriormente foram adotadas pelos romanos e atribuídas também ao deus Mercúrio. Hermes era o responsável por levar os espíritos dos mortos para o além e de também proteger os viajantes e, sendo:

\begin{abstract}
"Mensageiro por excelência, chamado às vezes por uma palavra que deu Evangelho, mensageiro da boa-nova, Hermes simboliza os meios de troca entre o Céu e a Terra, a mediação, em suma, meios que se podem perverter em comércio simoníaco ou elevar-se ao contrário, até a santificação. Assegura a viagem, a passagem entre os mundos infernais, terrestres, celestes." (CHEVALIER, 1994, p.487)
\end{abstract}

isto porque:

\begin{abstract}
"para os gregos, todavia, Hermes, regia as estradas porque andava com incrivel velocidade, pelo fato de usar sandálias de ouro, e, se não se perdia na noite era porque, "dominando as trevas", conhecia perfeitamente o roteiro. Com a rapidez que lhe emprestavam suas sandálias divinas e com o domínio dos três níveis, tornou-se o mensageiro predileto dos deuses, sobretudo de seu pai Zeus e do casal ctônio, Hades e Perséfone." (BRANDÃO, 1991, Volume I, p.550).
\end{abstract}

Além de ser considerado deus do comércio e também da boa sorte, é considerado uma "divindade complexa, com múltiplos atributos e funções, Hermes parece ter sido, de início, um deus agrário, protetor dos pastores nômades indo-europeus e dos rebanhos, daí seu epíteto de Crióforo, por ser muitas vezes representado com um carneiro sobre os ombros.” (BRANDÃO, 1991, Volume I, p.549)

Tradicionalmente representado usando um chapéu e sandálias com asas, características estas que mais tarde o fizeram referência clássica da convenção dos mensageiros de Deus, Hermes permitiu que mais tarde Jean Chevalier, ao estudá-lo em seu Dicionário dos Símbolos, utilizasse da obra de Gaston Bachelard "L'air et les songes" como referência, permitindo-o ponderar que: 
“(...) Gaston Bachelard vê no calcanhar dinamizado, o símbolo do viajante noturno, dos sonhos de viagem. E o autor compara essas asas no calcanhar aos calçados, denominados pés ligeiros, de santos budistas a viajarem pelos ares; aos sapatos voadores dos contos populares; às botas de sete léguas:Para o homem que está sonhando, é no pé que estão as forças voadoras... Nós nos permitiremos, pois, em nossas pesquisas de metapoética, conclui Bachelard, designar essas asas no calcanhar sob a denominação de asas oníricas" (CHEVALIER, 1994, p.91)

O que nos permite concluir que para estes autores:

“(...)a asa, símbolo de dinamismo, sobrepõe-se aqui ao símbolo de espiritualização; presa ao pé, ela não implica necessariamente uma ideia de sublimação, mas, sim, de liberação de nossas mais importantes forças criadoras: o poeta, assim como o profeta, tem asas no momento em que está inspirado (CHEVALIER, 1994, p.91).

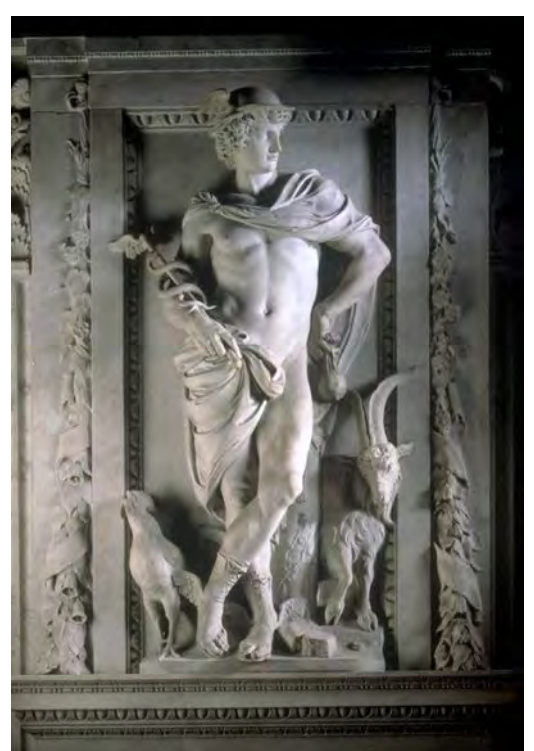

Figura 14: Estátua de Mercúrio - Bureau Monumentenzorg - Amsterdam ${ }^{19}$

Já na Antiguidade, acreditava-se e refletia-se sobre tais espíritos alados, tais como Hermes. É algo que podemos encontrar em Platão, discípulo de Sócrates, quando em Fedro, este cita as ideias de seu mestre para descrever tais seres mitológicos com asas:

\footnotetext{
"Então, quando está perfeito e alado, ele viaja nas alturas e controla o mundo inteiro: mas aquele que abaixou suas asas desce até que se possa firmar em algo sólido (...) A propriedade natural de uma asa é erguer esta, que é pesada, e levá-la suspensa até a região onde habitam os deuses; e mais do que qualquer outra parte do corpo, ela possui a essência divina" (PLATÃO apud LEWIS, 1999, p. 174)
}

\footnotetext{
${ }^{19}$ Disponível em: <http://commons.wikimedia.org/wiki/File:Mercurius.jpg?uselang=pt> Acesso em: 06/04/14
} 
Graças aos esforços de estudiosos e arqueólogos e aos acervos mantidos pelos museus mais importantes do mundo é que hoje nos é permitido compreender como os gregos e romanos viam as características estéticas de Hermes (que por vezes surge com barba e cabelos longos) pintadas em murais, jarros e adornos decorativos como os ilustrados a seguir:
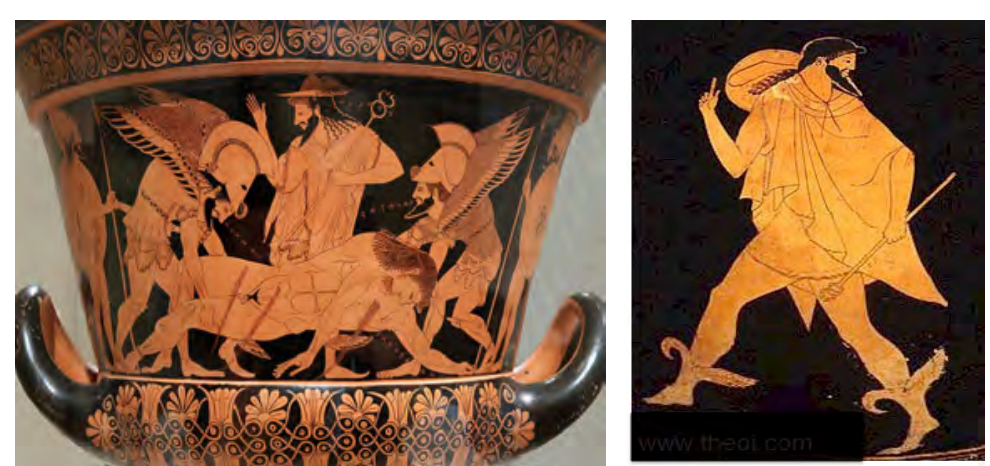

Figuras 15 e 16: Jarro ilustrando Hypnos e Thanatos carregando o corpo de Sarpedon enquanto Hermes observa $^{20} \mathrm{e}$ a figura de Hermes ${ }^{21}$ - séc. V a.C. - Metropolitan Museum of Art - New York

\subsubsection{Eros / Cupido}

Além de Hermes, a mitologia grega, rica em mitos alados, nos presenteou também com Eros, filho de Afrodite e considerado o deus do amor. Este ser mitológico surge na Grécia Antiga sob as mais variadas formas.

Nas primeiras fontes, ou seja, as cosmogonias, os textos dos primeiros filósofos e os demais textos referentes às religiões politeístas da época, Eros era retratado com um dos deuses primordiais envolvidos na existência do cosmos. Porém, com o passar do tempo, passa a figurar como o deus do amor e filho de Afrodite, um adolescente travesso que causava intervenções nos assuntos de deuses e mortais produzindo laços de amor, muitas vezes de forma ilícita.

Já aí nos é permitido notar as diferentes representações estéticas atribuídas à figura mitológica de Eros, na qual há “(...) um Eros bem mais arcaico, adolescente musculoso, de asas poderosas, um convite falaz para o sexo. Participa, como tal, de um

\footnotetext{
${ }^{20}$ Disponível em: <http://en.wikipedia.org/wiki/File:Euphronios_krater_side_A_MET_L.2006.10.jpg>Acesso em: 06/04/14

${ }^{21}$ Disponível em: <http://www.theoi.com/Gallery/K11.1.html> Acesso em: 06/04/14
} 
grupo tradicional de violadores alados, que transportam suas vítimas à força para locais inacessíveis (...).”(BRANDÃO, 1991, Volume I, p. 358) e uma outra iconografia que acredita que:

\begin{abstract}
"O fato de Eros ser uma criança simboliza, sem dúvida, a eterna juventude de um amor profundo, mas também uma certa irresponsabilidade. Em todas as culturas, a aljava, o arco, as flechas, a tocha, os olhos vendados significam que o Amor se diverte com as pessoas de que se apossa e domina, mesmo sem vê-las (o amor, não raro, é cego), ferindo-as e inflamando-lhes o coração.” (BRANDÃO, 1991, Volume I, pág. 357)
\end{abstract}

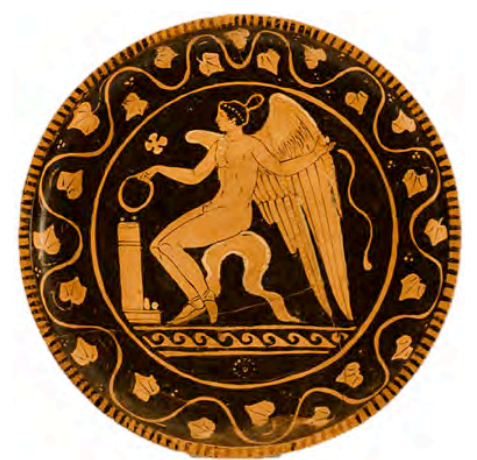

Figura 17: Prato em terracota com a figura de Eros - Walters Art Museum - $(340 \text { a .C - } 320 \text { a .C. })^{22}$

Em última análise porém, após os poetas satíricos, começa a ser representado como uma criança de olhos vendados, o precursor dos gordinhos Cupidos reproduzidos no Renascimento, bem diferente do Eros retratado na poesia e arte grega antiga, nas quais este era visto como um homem adulto que encarnava o poder sexual, o que nos faz compreender portanto, que:

\begin{abstract}
"Aos poucos todavia, sob a influência dos poetas, Eros se fixou e tomou sua fisionomia tradicional. Passou a ser apresentado como um garotinho louro, normalmente com asas. Sob a máscara de um menino inocente e travesso, que jamais cresceu...” (BRANDÃO, 1991, Volume I, pág. 357)
\end{abstract}

E é no século XVII que há uma alteração na evolução da iconografia dos anjos, na qual Eros também está inserido, isto porque se estabelece nesse período uma nova iconografia religiosa, em que a criança ocuparia uma figura quase central. É a partir deste momento que a pintura, a gravura e a escultura religiosa passaram a dar uma grande importância à

\footnotetext{
22 Disponível em: <http://en.wikipedia.org/wiki/File:Ascoli_Satriano_Painter_-_Red-Figure_Plate_with_Eros__Walters_482765.jpg> Acesso em: 06/04/14
} 
representação maior do menino Jesus por exemplo, do que junto da Virgem Maria ou da Sagrada Família.

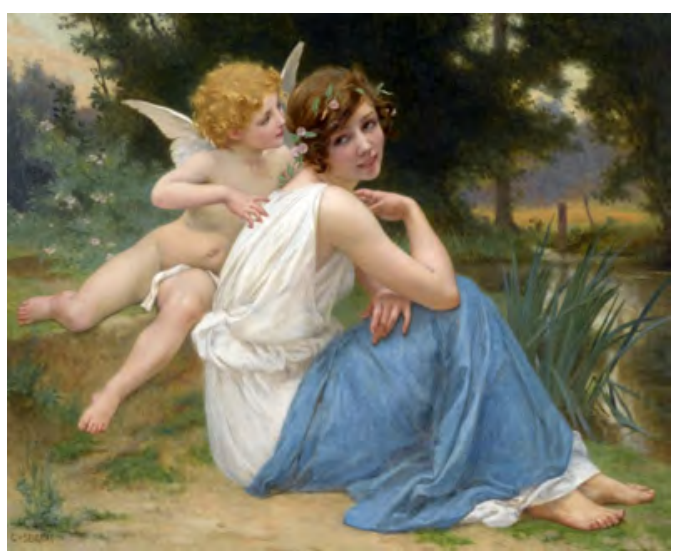

Figura 18: Cupido e Psyche - Guillaume Seignac - Private collection ${ }^{23}$

A figura de uma alma sendo conduzida por anjos, sendo estes representados sob a forma de crianças ou adolescentes, tornou-se mais comum na iconografia dos séculos XVI e XVII, quando a infância era encarada como“(...) um símbolo de inocência: é o estado anterior ao pecado e, portanto o estado edênico, simbolizando em diversas tradições pelo retorno ao estado embrionário(...).” (CHEVALIER, 1994, p.302) o que serviu de argumento para a Igreja Católica onde “(...) na tradição cristã, os anjos são muitas vezes representados como crianças, em sinal de inocência e de pureza.” (CHEVALIER, 1994, p.302) fazendo com que esta instituição religiosa, que após alguns anos lutando contra os iconoclastas ${ }^{24}$, posteriormente alterasse seu posicionamento através de seus Concílios, alterando toda a iconografia cristã como forma de não perder fiéis, por já estar ameaçada pela Reforma Protestante.

Sendo assim, nos é permitido concordar com Philippe Ariès, quando este em sua obra História Social da Criança e da Família, afirma que:

“(...) não se trata apenas de uma representação simbólica da alma sob a aparência tradicional da criança (esse recurso à criança para representar a alma é, aliás, uma curiosa ideia medieval) - trata-se da ilustração de uma devoção particular da infância, derivada do sacramento do batismo: o anjo da guarda (ARIÈS, 1981, p. 25)

\footnotetext{
${ }^{23}$ Disponível em: <http://www.wikigallery.org/wiki/painting_86516/Guillaume-Seignac/Cupid-and-Psyche> Acesso em 06/04/14

${ }^{24}$ Iconoclastia ou Iconoclasmo foi um movimento político-religioso contra a veneração de ícones e imagens religiosas no Império Bizantino que começou no início do século VIII e perdurou até ao século IX. Os iconoclastas acreditavam que as imagens sacras seriam ídolos, e a veneração e o culto de ícones por consequência, idolatria.
} 
Provavelmente seja Eros o maior referencial iconográfico em relação à concepção do mito do anjo atual devido a suas diversas possíveis representações, como podemos notar no quadro sinótico que segue:

\section{TABELA 1 - DIFERENTES REPRESENTAÇÕES DE EROS}

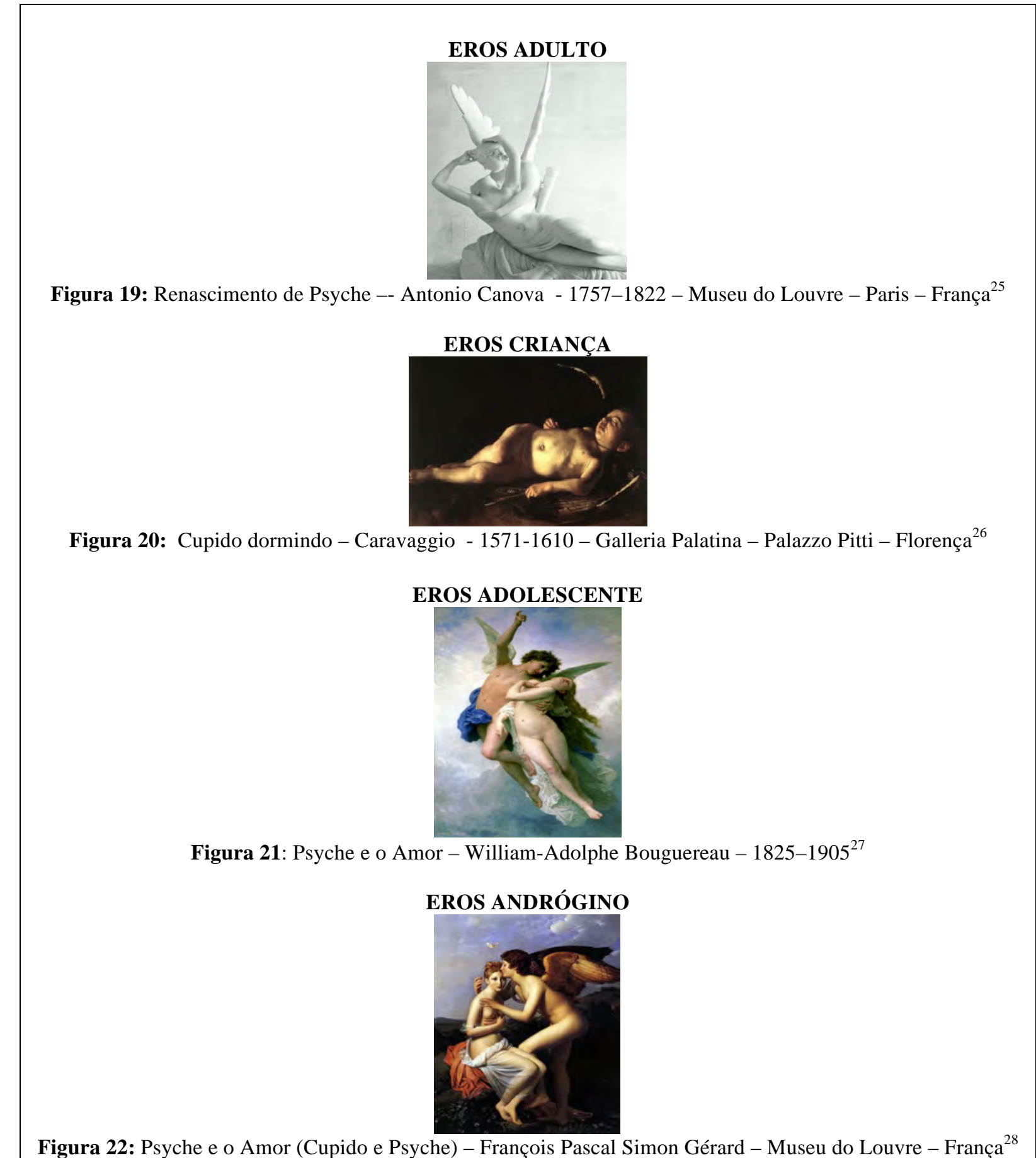

${ }^{25}$ Disponível em: <http://en.wikipedia.org/wiki/File:Psyche_revived_Louvre_MR1777.jpg> Acesso em 06/04/14

${ }^{26}$ Disponível em: 〈http://upload.wikimedia.org/wikipedia/commons/4/49/Caravaggio_sleeping_cupid.jpg> Acesso em 06/04/14

${ }^{27}$ Disponível em: <http://commons.wikimedia.org/wiki/File:Psyche_et_LAmour.jpg> Acesso em 06/04/14 


\section{EROS COM ASAS DE PÁSSARO E COLORIDAS}

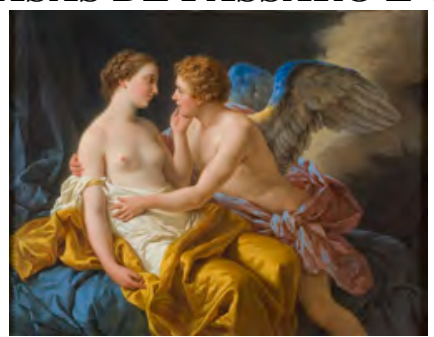

Figura 23: Figura: Amor e Psyche - Louis Jean Francois Lagrenée 29

EROS ARCAICO
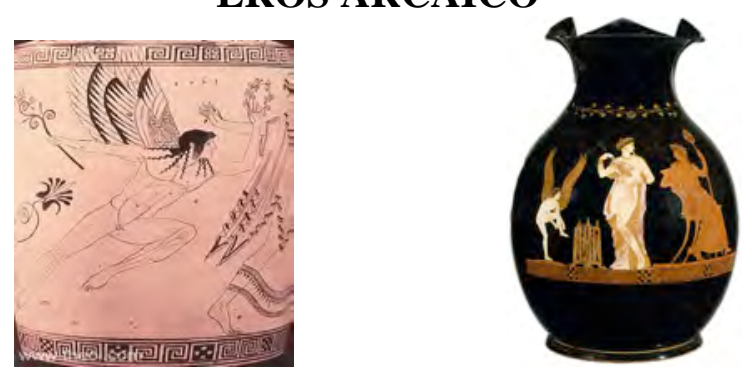

Figura 24: Eros - Atribuído a Douris - Cleveland Museum of Art - 500 a .C - 495 a .C ${ }^{30}$

Figura 25: Vaso Pompeu entre Eros e Dionísio - Século IV a.C - The Metropolitan Museum of Art - New York $^{31}$

Fonte: Tabela produzida pela autora

\subsubsection{De Ícaro e Morfeu a Tânatos e as Hárpias}

Avaliando o quadro mais atentamente, é possível que tais divergentes representações sejam referenciais para os mensageiros celestiais atuais que são retratados hoje de maneiras das mais diversas como visualizaremos e explanaremos posteriormente nesta dissertação. Tal fato nos leva a pensar que, com o passar dos anos, os mitos transformam-se de acordo com o tempo e a cultura em que acabam sendo inseridos, como forma de facilitar a comunicação e de estarem mais próximos dos interpretantes e receptores do que se deseja transmitir.

Buscamos listar os mitos que podem ter sido os precursores dos anjos cristãos. Outros tantos mitos gregos poderiam ter sido aqui citados, devido as suas características aladas, porém sem qualquer alusão ao caráter mensageiro como é o caso, por exemplo, de:

\footnotetext{
${ }^{28}$ Disponível em: <http://en.wikipedia.org/wiki/File:Image-François_Pascal_Simon_Gérard_006.jpg> Acesso em 06/04/14

${ }^{29}$ Disponível em: <http://en.wikipedia.org/wiki/File:Louis_Jean_Francois_Lagrenée_-_Amor_and_Psyche.jpg> Acesso em 06/04/14

${ }^{30}$ Disponível em: <http://www.theoi.com/Gallery/K32.8.html> Acesso em 06/04/14

${ }^{31}$ Disponível em: <http://www.theoi.com/Gallery/K32.8.html> Acesso em 06/04/14
} 
"Ícaro é o símbolo do intelecto que se tornou insensato, da imaginação pervertida. É uma personificação mítica da deformação do psiquismo, caracterizada pela exaltação sentimental e vaidosa. Ícaro representa o emotivo e a sorte que o espera. A tentativa insana de Ícaro é proverbial pela emotividade no mais alto grau, por uma forma de aberração do espírito: a mania das grandezas, a megalomania" (DIEL, 1966, p.50)

ou ainda, Morfeu:

"Como a maioria das divindades do sono e do sonho, (...) era alado e possuía extrema facilidade para se fazer passar por um ser humano. Voava em absoluto silêncio e atingia num instante as extremidades da terra. Esvoaçando sobre qualquer ser humano ou pousando-lhe sobre a cabeça, podia fazê-lo adormecer instantaneamente ou provocar sonhos nos já adormecidos" (BRANDÃO, 1991, Volume II, p.147)

Além é claro de Hypno, Tânatos e outros tantos deuses ou demônios que habitaram o panteão grego como é o caso das Erínias, das Hárpias, da Fênix e até mesmo o cavalo alado Pégasus ou então seres mitológicos de outros tempos e culturas como é o caso das Valquírias, deusas originadas da mitologia nórdica, e que apesar de serem consideradas deidades menores e servas de Odin, eram belas e jovens mulheres que, armadas de elmos e lanças de guerreiras, sobrevoavam os campos de batalha em cavalos alados buscando guerreiros recém-abatidos para acompanhá-las a Valhala, porém, todos aqui citados, apesar de suas características aladas, não são de relevância para este estudo.
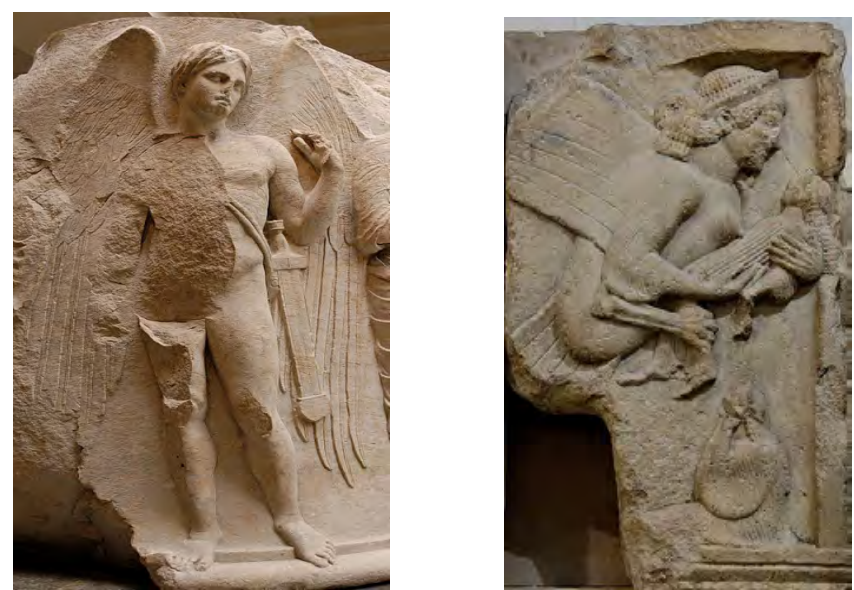

Figura 26: Tânatos - Escultura em mármore - London British Museum - 325-300 d.C. ${ }^{32}$ Figura 27: Hárpia - Fragmento do friso norte da tumba de Kybernis, acrópole de Xantos - British Museum ${ }^{33}$

\footnotetext{
${ }^{32}$ Disponível em: 〈http://en.wikipedia.org/wiki/File:Column_temple_Artemis_Ephesos_BM_Sc1206_n3.jpg> Acesso em 06/04/14

${ }^{33}$ Disponível em:

<http://www.britishmuseum.org/explore/highlights/highlight_image.aspx ?image=ps267219.jpg\&retpage=18281> Acesso em $07 / 04 / 14$
} 


\section{4. Os anjos e suas hierarquias}

$\mathrm{O}$ anjo mensageiro mais famoso é Gabriel. Na história do Cristianismo, é ele o responsável por avisar a Maria que esta trará ao mundo o filho de Deus. O nome Gabriel significa exatamente "Herói de Deus" e tal nome e título juntos sugerem que este seja um anjo de uma ordem superior, ou seja, um arcanjo, confirmando o que Jean Chevalier cita ao abordar a hierarquia angelical de Pseudo-Dionísio, o Areopagita, quando disserta sobre as possíveis atribuições de cada tipo de anjo, na qual estes:

"Ocupariam para Deus as funções de ministros: mensageiros, guardiães, condutores de astros, executores de leis, protetores dos eleitos etc., $e$ estariam organizados em hierarquias de sete ordens, de nove coros ou de três tríades. Dionísio, o Aeropagita elaborou a respeito dos anjos a mais perfeita e a mais mística das teorias em suas Hierarquias celestes." (CHEVALIER, 1994, p.60)

Já nas antigas civilizações, os deuses e espíritos eram frequentemente representados com características não humanas, como animais com chifres e asas. Imagens com seres alados ilustram ainda hoje, em museus, as tumbas de faraós do Egito. Durante milhares de anos, antes mesmo do surgimento de Jesus Cristo, os espíritos alados representavam a conexão com o outro mundo. No universo greco-romano e sua rica cultura, figuras semidivinas assemelhavam-se pelo menos em um primeiro momento aos nossos conhecidos anjos. A deusa Nique/Niké, representante do símbolo alado da vitória, Eros, a criança alada com arco e flecha, Hermes um mensageiro alado com sapatos voadores não seriam eles indícios da função essencial dos anjos?

Durante muito tempo, a composição da imagem da figura alada esteve vigorosamente atrelada à religião e às artes, principalmente em virtude do estudo da História da Arte, marcada pela presença constante de imagens com a presença destes seres, ora ligados a homens, a mulheres ou a algum tipo de animal - algo muito comum em culturas da Antiguidade.

Porém, com o início da Era Cristã, os anjos transformaram-se em seres superiores, intangíveis e inteligentes. De acordo com a Igreja Católica, são apresentados como seres protetores com a responsabilidade pelo bem-estar dos indivíduos em dificuldade. Sua forma ficou muita associada principalmente a crianças e jovens amantes, em função da ampla utilização dos anjos barrocos e do Cupido como seus maiores representantes. 
Segundo o Professor Emérito da Escola de Teologia e Estudos Religiosos da Universidade de Wales in Bangor, Prof. Dr. Gareth Lloyd Jones, na Antiguidade, as pessoas acreditavam que o mundo era dividido em partes: ou seja, o inferno embaixo, a terra no meio e o céu em cima e era lá que ficava o mundo invisível, o reino de Deus, o paraíso. Quando as pessoas olhavam para cima, buscavam um mundo invisível, cercado de seres sublimes e espíritos bons que viriam nos visitar e que estariam a nossa volta assim como no céu.

Durante a Idade Média, estabeleceu-se uma intrincada hierarquia no paraíso que posteriormente chegou a ser representada em pinturas e vitrais de igrejas. A hierarquia existente nos céus estaria relacionada à ligação que os anjos possuem com Deus e neste sentido, não existe um senso comum em relação às diferentes escalas hierárquicas destinadas a estes seres alados celestiais, mesmo quando as relacionamos com a Bíblia cristã.

Isso pode ser comprovado, pois é justamente na Idade Média que inúmeros personagens ligados às tradições cristãs propuseram organizações de quadros sintéticos, abordando de maneiras diversas a hierarquia angelológica, com as seguintes nomenclaturas e escalas, conforme segue (BAU \& KOHLER, 2013) $)^{34}$ :

\begin{tabular}{|l|l|l|l|}
\hline ESTUDIOSOS & \multicolumn{1}{|c|}{ OBRA } & PERÍODO & \multicolumn{1}{c|}{ ESCALA HIERÁRQUICA } \\
\hline Ambrósio & $\begin{array}{l}\text { Em Apologia do } \\
\text { Profeta David }\end{array}$ & século IV & $\begin{array}{l}\text { 1.Serafins, 2.Querubins, 3.Dominações, 4.Tronos, } \\
\text { 5. Principados, 6.Potestades, 7. Virtudes, 8. Anjos, } \\
\text { 9.Arcanjos }\end{array}$ \\
\hline Jerônimo & - & século IV & $\begin{array}{l}\text { 1. Serafins, 2. Querubins, 3. Potestades, } \\
\text { 4. Dominações, 5. Tronos, 6. Arcanjos, 7.Anjos }\end{array}$ \\
\hline $\begin{array}{l}\text { Pseudo-Dionísio, } \\
\text { o Areopagita }\end{array}$ & $\begin{array}{l}\text { em De Coelesti } \\
\text { Hierarchia }\end{array}$ & século V & $\begin{array}{l}\text { 1.Serafins, 2. Querubins, 3.Tronos, 4.Dominações, } \\
\text { 5. Virtudes, 6. Potestades, 7. Principados, 8. Arcanjos, } \\
\text { 9. Anjos. }\end{array}$ \\
\hline Gregório Magno & Em Homilia & século VI & $\begin{array}{l}\text { 1.Serafins, 2. Querubins, 3. Tronos,4. Dominações, } \\
\text { 5.Principados, 6. Potestades, 7. Virtudes, 8. Arcanjos, } \\
\text { 9. Anjos. }\end{array}$ \\
\hline $\begin{array}{l}\text { Isidoro de } \\
\text { Sevilha }\end{array}$ & Em Etymologiae & século VII & $\begin{array}{l}\text { 1. Serafins, 2. Querubins, 3. Potestades, 4. Principados, } \\
\text { 5. Virtudes, 6. Dominações, 7. Tronos, 8. Arcanjos, } \\
\text { 9. Anjos. }\end{array}$ \\
\hline $\begin{array}{l}\text { João de } \\
\text { Damasco }\end{array}$ & $\begin{array}{l}\text { Em De Fide } \\
\text { Orthodoxa }\end{array}$ & século VIII & $\begin{array}{l}\text { 1. Serafins, 2.Querubins, 3. Tronos, 4. Dominações, } \\
\text { 5.Potestades, 6. Autoridades (Virtudes), 7. Governantes } \\
\text { (Principados), 8. Arcanjos, 9. Anjos. }\end{array}$ \\
\hline $\begin{array}{l}\text { Tomás de } \\
\text { Aquino }\end{array}$ & $\begin{array}{l}\text { Em Summa } \\
\text { Theologica }\end{array}$ & 1225-1274 & $\begin{array}{l}\text { 1. Serafins, 2.Querubins, 3. Tronos, 4. Dominações, 5. } \\
\text { Virtudes, 6. Potestades, 7. Principados, 8. Arcanjos, } \\
\text { 9. Anjos. }\end{array}$ \\
\hline Dante Alighieri & $\begin{array}{l}\text { Em Divina } \\
\text { Comédia }\end{array}$ & $\begin{array}{l}\text { 1. Serafins, 2. Querubins, 3. Tronos, 4. Dominações, } \\
\text { 5. Virtudes, 6. Potestades, 7. Arcanjos, 8. Principados, } \\
\text { 9.Anjos. }\end{array}$ \\
\hline
\end{tabular}

Fonte: Enciclopédia Judaica online

\footnotetext{
${ }^{34}$ Quadro sintético produzido pela autora com informações extraídas da Enciclopédia Judaica on line/ Jewish Encyclopedia in: BLAU \& KOHLER. Ludwig, Kaufmann. Angelology. In Jewish Encyclopedia, disponível em: http://www.jewishencyclopedia.com/articles/1521-angelology; Acesso em 8 de dezembro de 2013.
} 
Contudo, notamos que quando o assunto abordado é a hierarquia angelical, apesar dos diferentes "rankings" existentes, as adotadas e aceitas pela Igreja Católica e frequentemente mencionadas na atualidade são apenas as de Pseudo-Dionísio, o Areopagita e a de São Tomás de Aquino. Tais modelos não surgiram de textos sagrados, mas sim dos escritos de um monge sírio do século V, Pseudo-Dionísio, o Areopagita que buscou dividir os anjos em nove diferentes categorias e classificou-os de acordo com sua importância.

Nesta hierarquia divina, os anjos mais importantes são os "serafins" e "querubins", ou seja, aqueles que estariam mais próximos de Deus e cuja atribuição seria a de apenas venerá-lo. Abaixo destes vem as chamadas "virtudes", que são as responsáveis pela realização dos milagres, depois os "tronos" que trazem justiça, as "dominações" que ministram o paraíso, as "potestades", que buscam proteger a humanidade do mal, e por fim os "principados" que preocupam-se com o bem-estar das nações, seguidos finalmente pelos arcanjos e os anjos que aparecem como guias e mensageiros dos humanos.

$\mathrm{Na}$ figura 28, retirada da reportagem "A inspiração eterna dos Anjos", divulgada na Revista Veja de dezembro de 2010, é possível notar como Dionísio, o Areopagita subdividiu em classes os seres angelicais, atribuindo a cada um dos níveis existentes funções bem distintas: 


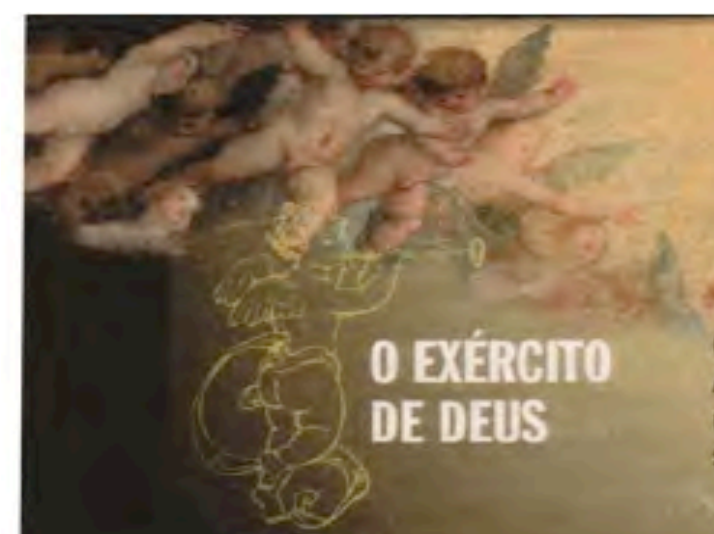

\section{SERAFINS}

São os anjos mais próximos de Deus. Cercam o trono divino, cantando sem parar "Santo, santo, santo". Há variaģōes na tradição sobre quem seria o chefe dos serafins: Metatron, Miguel - ou mesmo Lúcifer, antes da queda. No entanto, aparecem apenas uma vez na Biblia, no Livro de Isaias

\section{QUERUBINS}

No Gênesis, sầo os guardiôes

que impedem os homens de retornar ao Paraiso. No Livro de Ezequiel, figuram como criaturas. um tanto monstruosas. com quatro asas e quatro rostos. Na iconografia moderna, porém. ganham quase sempre a forma rechonchuda de um menininho com asas
Exis
Conhecido apenas pelo pseudônimo Dionísio Areopagita, um teólogo do século V ou VI criou uma hierarquia angélica de nove categorias que se tornou muito influente na Igreja Católica

\section{VIRTUDES}

Sua funçấo seria a de fazer milagres no mundo humano. Seriam os anjos da guarda aludidos por Jesus em Mateus

\section{POTESTADES}

Seriam uma espécie de polícia do cếu. São Paulo, que nāo era um admirador dos anjos em geral, fala das potestades com especial desconfianca

\section{PRINCIPADOS}

Defensores da religiâo, geralmente associados a um pais ou continente em particular

\section{TRONOS}

Nāo aparecem na Bíblia, mas são referidos em lendas de rabinos. Sua funçầo é obscura. Muitos teriam caido do céu. junto com Lúcifer

$\cdot$

\section{DOMINAC̄̃̃ES}

Seriam os anjos mais antigos. Ainda assim. têm papel muito pequeno na tradiçăo religiosa

\section{parction}


Vale ressaltar que a obsessão e a fixação pela natureza da possível ordem existente no paraíso e seus anjos, atravessaram os séculos, chegando ao seu ápice durante a Idade Média, quando esta visão do paraíso foi colocada em questão. Sucessor de Dionísio, Tomás de Aquino, um frade dominicano que viveu no século XIII, também escreveu sobre os anjos e justamente por essa razão ficou conhecido como Dr. Angélico.

Em sua mais importante obra "Cidade de Deus", podemos encontrar tudo o que se refere ao universo angelical estudado por Aquino a respeito destes seres celestiais, mas que por receio ou incredulidade de alguns, comumente não se questiona. São encontradas respostas para perguntas, tais como: Os anjos se alimentam? Movem-se com velocidade? Podem morrer? Possuem filhos? Como se dá a comunicação entre eles? Além é claro da famosa e célebre pergunta: Qual é de fato o sexo dos anjos?

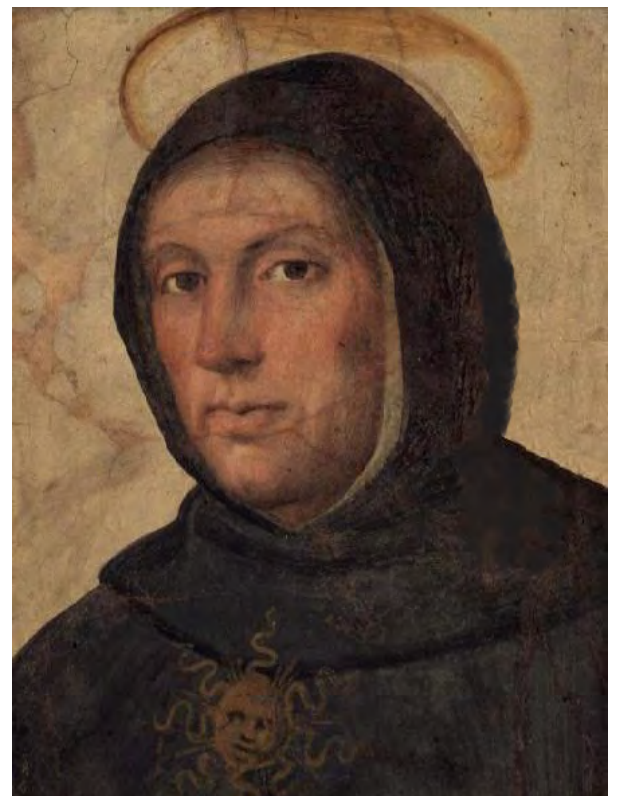

Figura 29: Santo Tomás de Aquino retratado por Fra Bartolommeo ${ }^{35}$

${ }^{35}$ Disponível em: <http://commons.wikimedia.org/wiki/File:Thomas_Aquinas_by_Fra_Bartolommeo.jpg> Acesso em: $07 / 04 / 14$ 


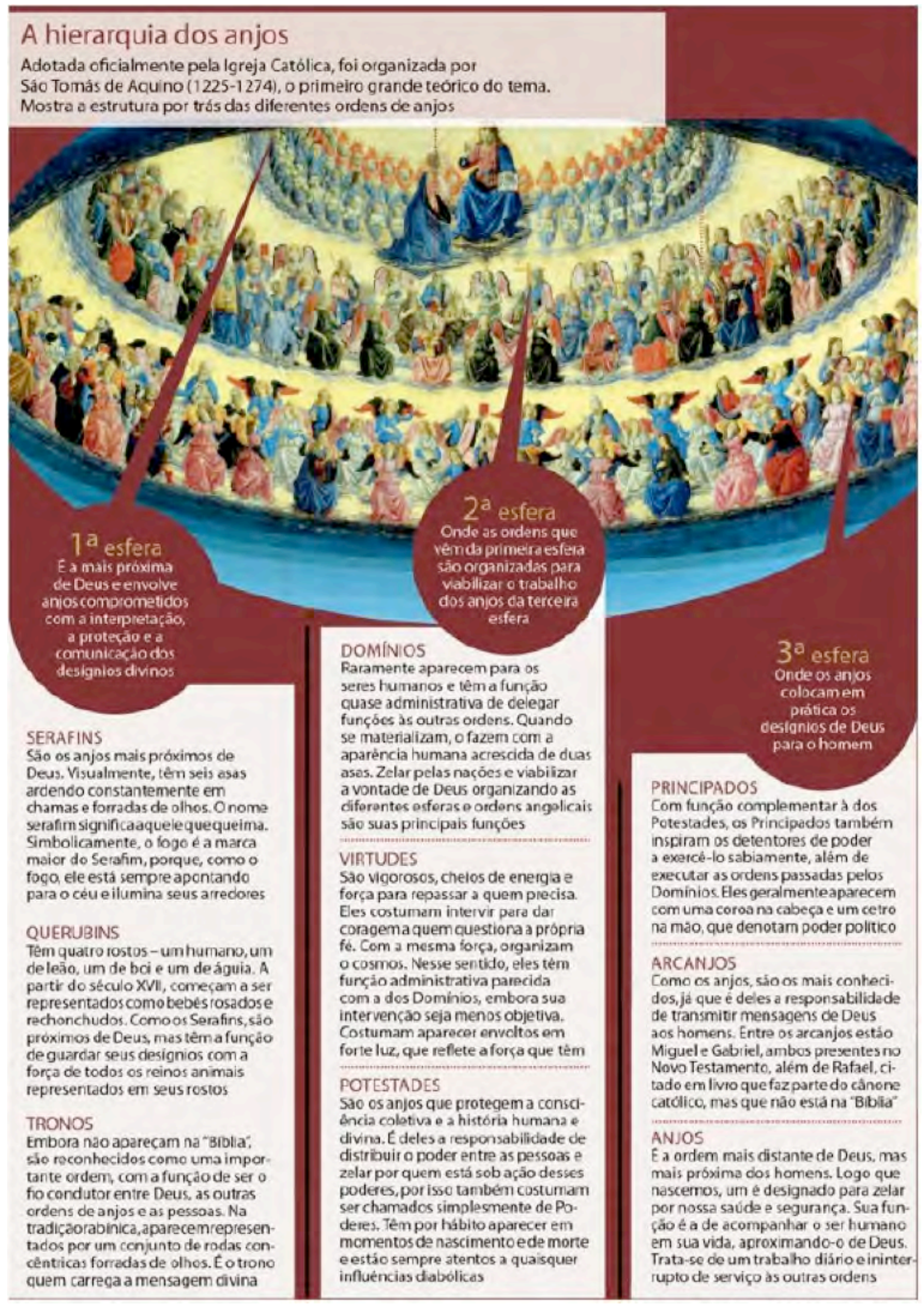

Figura 30: A hierarquia dos anjos segundo Tomás de Aquino. LOES, 2011, p. 84. 
Na figura 30, a Hierarquia dos Anjos criada por São Tomás de Aquino, foi detalhadamente retratada na reportagem "O poder dos Anjos", divulgada pela revista Isto É de dezembro de 2011.

Notamos que o objeto de estudo, bem como as hierarquias formuladas por Dionísio, o Areopagita e seu sucessor São Tomás de Aquino, despertam interesse e fascínio recorrentes sobre o assunto, visto que, posteriormente a publicação da revista Isto É, já aqui exposta e explanada, a revista Mundo Estranho, produzida pela Editora Abril, publicou em sua edição de setembro de 2013, reportagem principal de capa tendo como abordagem principal a existência e a correlação entre o universo de anjos e demônios, bem como também retratou a Hierarquia criada por São Tomás de Aquino.

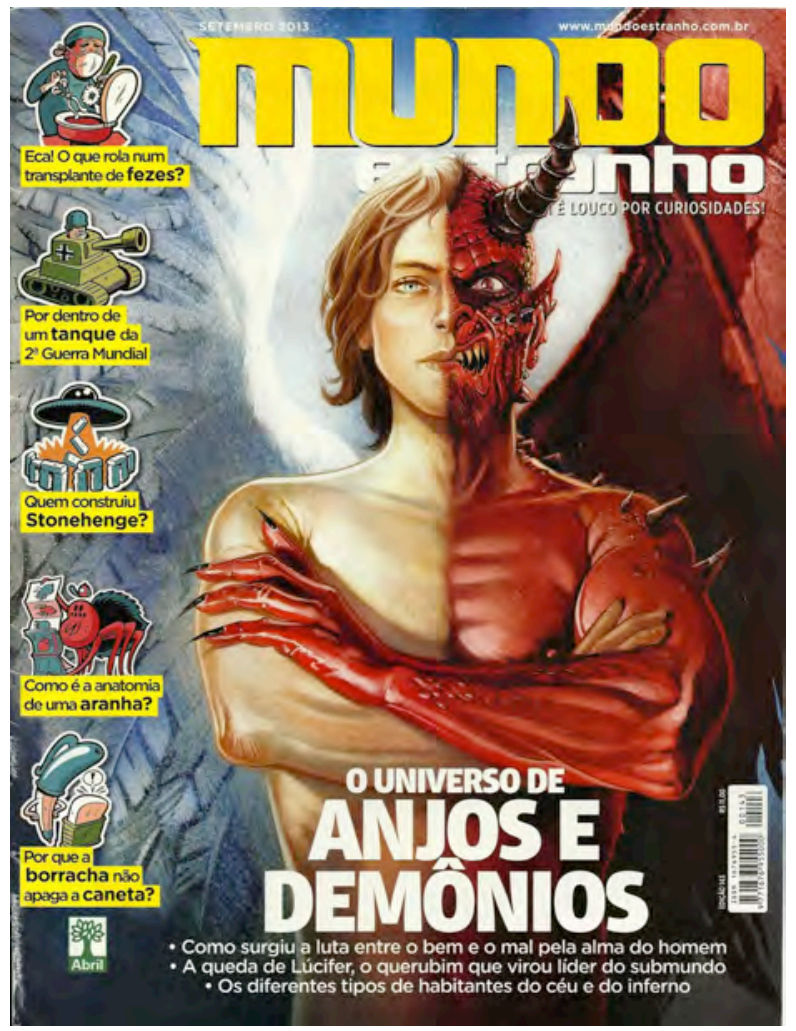

Figura 31: Do céu ao inferno. LIMA, 2013 p. 19 


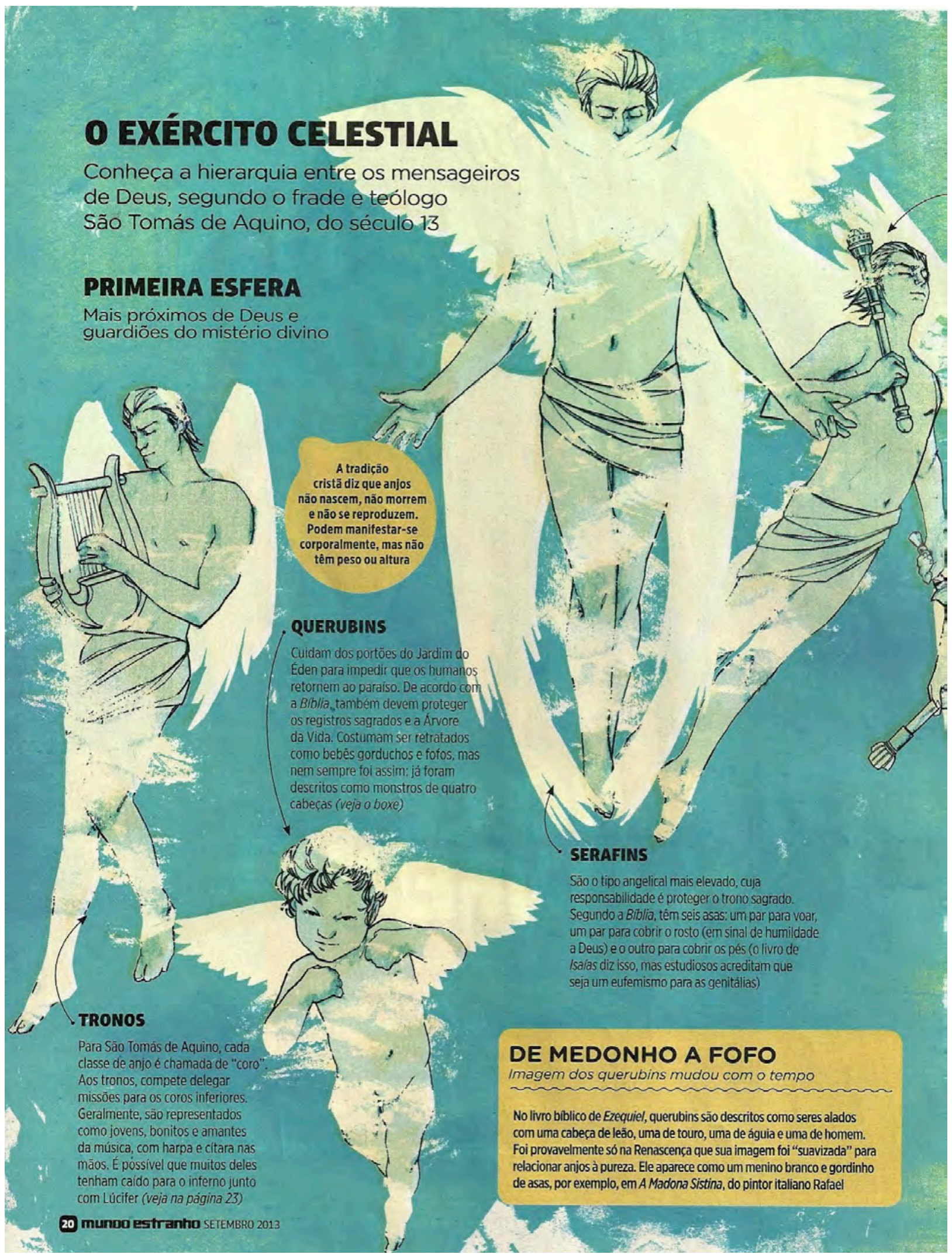

Figura 32: O Exército Celestial. LIMA, 2013 p. 20 


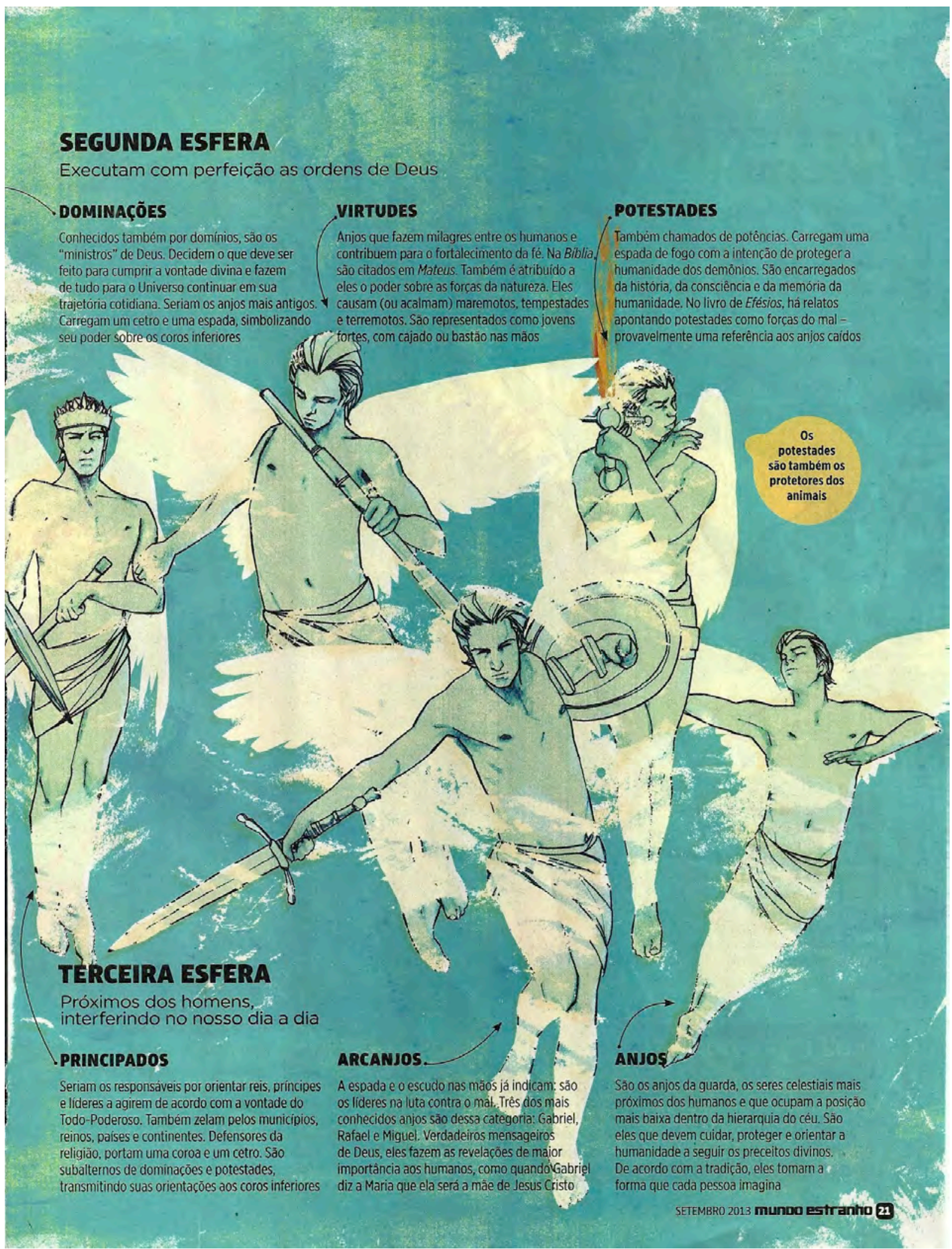

Figura 33: O Exército Celestial. LIMA, 2013 p. 21 
Mas após esse período, mais especificamente no século XVI com o surgimento da Reforma Protestante ${ }^{36}$, liderada por Martinho Lutero, monge católico agostiniano e professor de teologia germânico, ficou claro que os protestantes não simpatizavam com os anjos. Segundo o Prof. Gareth Lloyd Jones, Calvino, um dos principais personagens dessa Reforma, dizia ser perda de tempo falar sobre tal assunto, visto que nos livros sagrados não havia nada sendo discutido sobre a natureza dos anjos. Porém há muitas discussões sobre o trabalho desses seres alados, como o momento da visita do anjo Gabriel à Maria que não nos traz nenhuma descrição visual deste anjo. Nem Maria comenta que viu um anjo, ela apenas o escutou.

Mas como saber qual a aparência que um anjo possui? Durante séculos, artistas desenharam anjos e ao fazê-lo, acabaram influenciando para sempre a forma como os imaginamos fisicamente. De qualquer maneira, notamos que a maior tendência é a de justamente uma representação artística humanizada dos anjos, seja esta retratada em um vitral, em uma pintura ou em uma estátua.

Segundo Louise Govier da National Gallery em Londres, o Velho Testamento geralmente descreve os anjos como homens quando os primeiros visitam a Terra e que os anjos não possuem asas, afirmação esta posteriormente enfatizada pelo padre italiano Renzo Lavatori, especialista católico sobre arte angelical e que em entrevista dada ao site Hoje em Dia em 20/12/2013, ao comentar sua participação em debate organizado pela Fondazione Archivio Storico no Vaticano, reiterou que: "Os anjos existem, mas não têm asas e se parecem mais com feixes de luz" ou ainda "É preciso entender que não são representações reais. Os anjos não têm asas, nem se parecem com querubins".

Porém, percebemos que quando surgem nas artes do século IV em diante, tal concepção destes seres alados é alterada, isto porque foi nessa época que o Império Romano adotou o Cristianismo como a religião do Estado e a ideia do anjo estava muito associada às deusas greco-romanas como a estátua de mármore da deusa Vitória (Nique) que usa um manto feminino e possui asas. Ainda segundo Louise Govier, com o desenvolvimento das artes, a tendência foi encontrar formas masculinas sendo utilizadas para representação dos anjos, porém utilizando para isso mantos femininos e com asas. Foi uma espécie de "feminização" dos anjos, pois estes não eram totalmente femininos e raramente eram

\footnotetext{
${ }^{36}$ A Reforma Protestante foi um movimento reformista cristão culminado no início do século XVI por Martinho Lutero, que possuiu como principal intuito o protesto contra diversos pontos da doutrina da Igreja Católica Romana e consequentemente a exigência da reformulação de preceitos religiosos.
} 
retratados como mulheres, pois apesar de não possuírem seios, acabaram por ganhar um ideal de beleza essencialmente feminino.

Em contrapartida, Miguel, Rafael e Gabriel são nomes masculinos de anjos considerados do exército de Deus e que:

\begin{abstract}
“(...) transmitem suas ordens e velam sobre o mundo. Os anjos ocupam um lugar importante na Bíblia. Sua hierarquia está ligada à sua proximidade do trono de Deus. Citemos os nomes dos três principais arcanjos: Miguel (vencedor dos dragões), Gabriel (mensageiro e iniciador), Rafael (guia dos médicos e viajantes)." (CHEVALIER, 1994, p.61),
\end{abstract}

Porém, sabedores disso, é mais seguro supor que os anjos sejam seres assexuados. Isso evita perguntas embaraçosas e questões confusas.

A ideia da proteção de Deus é muito antiga. Os gregos acreditavam que, ao nascer, toda pessoa recebia um anjo que a acompanharia até o final da vida. Para os romanos toda mulher possuía um anjo da guarda chamado Juno e todo homem um anjo chamado Gênio, já na tradição judaica, acredita-se que toda pessoa é acompanhada na vida por dois anjos: um anjo bom que servirá para guiá-las e um anjo mau que fará de tudo para tentá-las. Essa ideia foi absorvida pelos cristãos e a crença nos anjos da guarda expandiu-se durante a Idade Média, embora:

"A Sagrada Escritura não faça nenhuma alusão aos anjos da guarda. Todavia, segundo Enoc, os santos e os justos possuem seus protetores. Cada fiel é assistido por um anjo, dirá Basílio, este anjo guia-lhe a vida, sendo ao mesmo tempo seu pedagogo e seu protetor. (...) Na Idade Média, os anjos intervinham em situações de perigo, nas guerras, nas cruzadas, etc." (CHEVALIER, 1994, p.61)

Foi também durante o século XVII que os anjos passaram a ser utilizados iconograficamente como estratégia política da Igreja Católica como forma de conter o infanticídio, que juntamente com o aborto eram práticas muito comuns da época.

\footnotetext{
"Essa representação da alma bem-aventurada sob a forma de uma criança, na maioria dos casos idealizada e nua, (...) deve ser comparada ao que foi dito (...) sobre o infanticídio e o batismo. De fato, para os espiritualistas medievais que estão na origem desse tipo de iconografia, a alma do eleito possuía a mesma inocência invejável da criança batizada(...)”. (ARIÈS, 1981, p.15)
} 
Nos tempos modernos, a ideia de anjo da guarda, o anjo que consola, tornou-se mais popular do que nunca, é possível encontrar anjos adornando lápides em cemitérios, como se estivessem acompanhando as almas deste mundo para o outro. As guerras foram também responsáveis pela popularização do anjo da guarda, justamente por empregarem nos seres humanos o desejo de acreditar em uma força poderosa superior que nos protege. Certamente não é por coincidência que as enfermeiras nos campos de batalha eram chamadas de "anjos de misericórdia".

Ainda hoje, crianças católicas são ensinadas a rezar para o seu anjo da guarda, invocando a proteção desses seres alados através da oração popularmente difundida: "Santo Anjo do Senhor, meu zeloso guardador. Se a ti me confiou a piedade divina. Sempre me rege, me guarda, me governa e me ilumina. Amém”.

Louise Govier, da National Gallery de Londres, ressalta ainda a importância do arcanjo Miguel. Seu nome significa "aquele como Deus" e foi adotado por muitas pessoas como símbolo. No Castelo de Santo Angelo em Roma, Miguel lança seu olhar protetor sobre a cidade eterna sempre a postos para defender o povo. Sua representação é a de um anjo guerreiro, constantemente retratado vestindo armaduras, com a intencionalidade de representar um ser imponente. A função de Miguel como anjo protetor das pessoas de bem surgiu nos anos 50, quando o Papa Pio XII transformou-o em padroeiro dos policiais. Miguel é o maior protetor entre os anjos. Mas vale aqui questionar: que papel protetor os anjos desempenham na cultura moderna?

$\mathrm{O}$ anjo moderno é um protetor, um amigo. Novas crenças nestes seres alados acabaram produzindo uma indústria toda própria. Há inúmeras publicações sobre o assunto, lojas vendendo imagens de anjos, místicos afirmando contatá-los, enfim, atualmente é possível encontrar tudo o que se relaciona com estes seres. Nos Estados Unidos, encontra-se a famosa cidade dos anjos - Los Angeles - e é curiosamente lá que a angeologia atingiu seu ápice.

Com os adventos tecnológicos e novos materiais surgindo, podemos afirmar que até mesmo o anjo, mito secular, também passou por mudanças estéticas representativas em sua concepção, isso porque, segundo Mr. John McEloy da Gateshead Council, a escultura de Antony Gormley, conhecida como "O anjo do norte", é a responsável por dar as boas-vindas e renovação a quem chega a cidade de Gasteshead situada na Inglaterra. Hoje em dia, quando solicitadas a ilustrarem um anjo, as crianças da cidade o fazem através da representação com a qual possuem maior convivência e proximidade, ou seja, um anjo enorme com asas de aço, 
por levarem em conta justamente o conhecimento que possuem de seu repertório e o contato com a obra do artista.

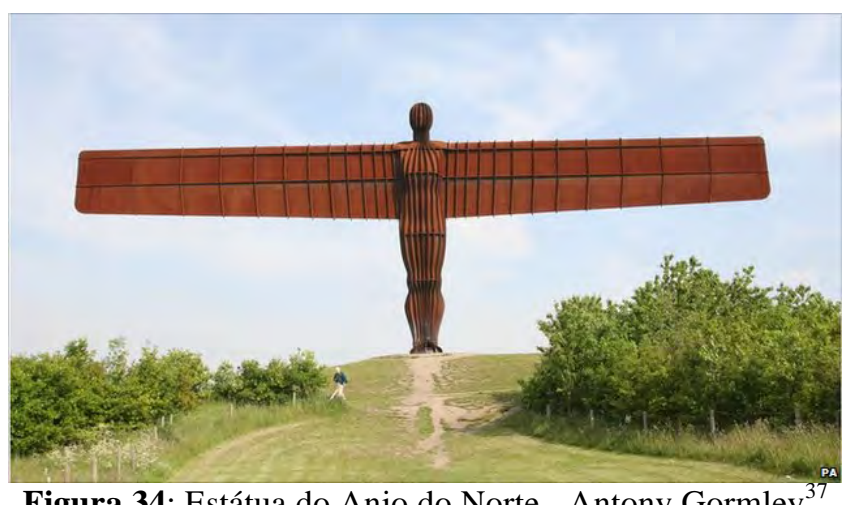

Figura 34: Estátua do Anjo do Norte - Antony Gormley ${ }^{3}$

Enquanto os anjos bons são reverenciados principalmente pelo Cristianismo, os anjos maus são temidos e diferidos pelos cristãos.

Mas quem foram os anjos do inferno originais? Segundo o Prof. Gareth Lloyd Jones, professor emérito da Escola de Teologia e Estudos Religiosos da Universidade de Wales em Bangor, o conceito de anjo caído é baseado nas Sagradas Escrituras. A $1^{\mathrm{a}}$. carta de Pedro versa sobre Deus punindo alguns anjos zombeteiros, mandando-os para o inferno. $\mathrm{Ou}$ ainda, há uma tradição que afirma que os anjos tiveram relações com os humanos o que desagradou a Deus.

Isaías conta a história da queda de Belial, o anjo das trevas, também citado como Lúcifer, Belzebú ou Satanás. Trata-se de um ser celestial que a priori foi bom, mas por ter desobedecido a Deus e tornando-se orgulhoso, permitiu que a soberba fosse sua desgraça, resultando em sua expulsão do céu.

O principal anjo do inferno é o Diabo, do grego $\delta l \alpha ́ \beta o \lambda o \varsigma$, que etimologicamente significa, o que separa, que provoca cisão. Na Bíblia, o diabo é retratado como serpente ou como dragão e também conhecido como Satã. O líder de todos os anjos caídos foi o responsável por tentar Adão e Eva e mais tarde Jesus Cristo. No Corão é mais conhecido como "Shaitã", o clássico sedutor. Através de representações visuais assustadoras, o diabo ou anjo caído mexe com nossa imaginação, como representado a seguir:

\footnotetext{
${ }^{37}$ Disponível em: <http://www.bbc.co.uk/tyne/content/image_galleries/northumbria_icons_angel_gallery.shtml?6> Acesso em: 07/04/14
} 


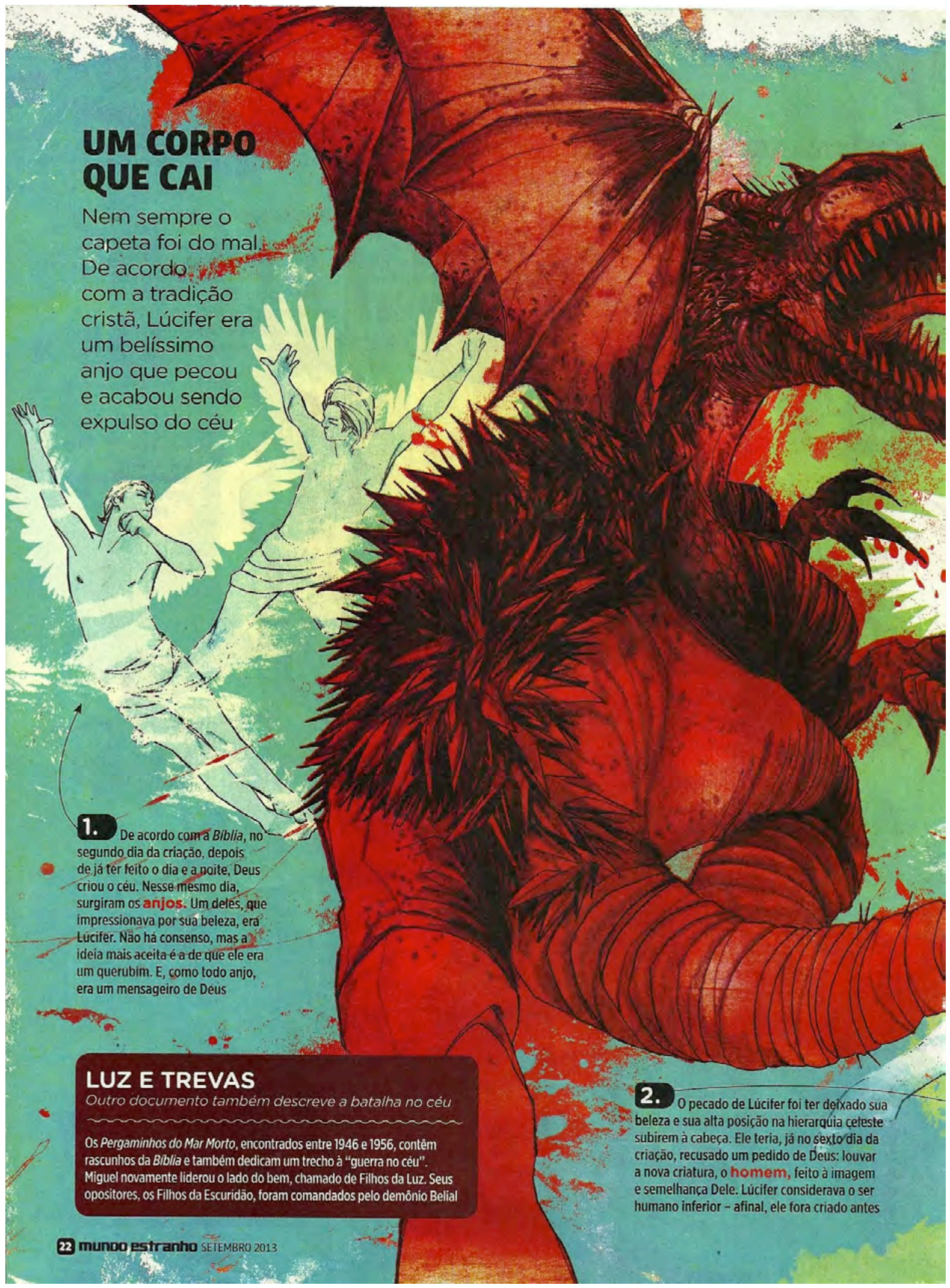

Figura 35: A queda de Lúcifer - Revista Mundo Estranho - Ed. Setembro 2013, p. 22 


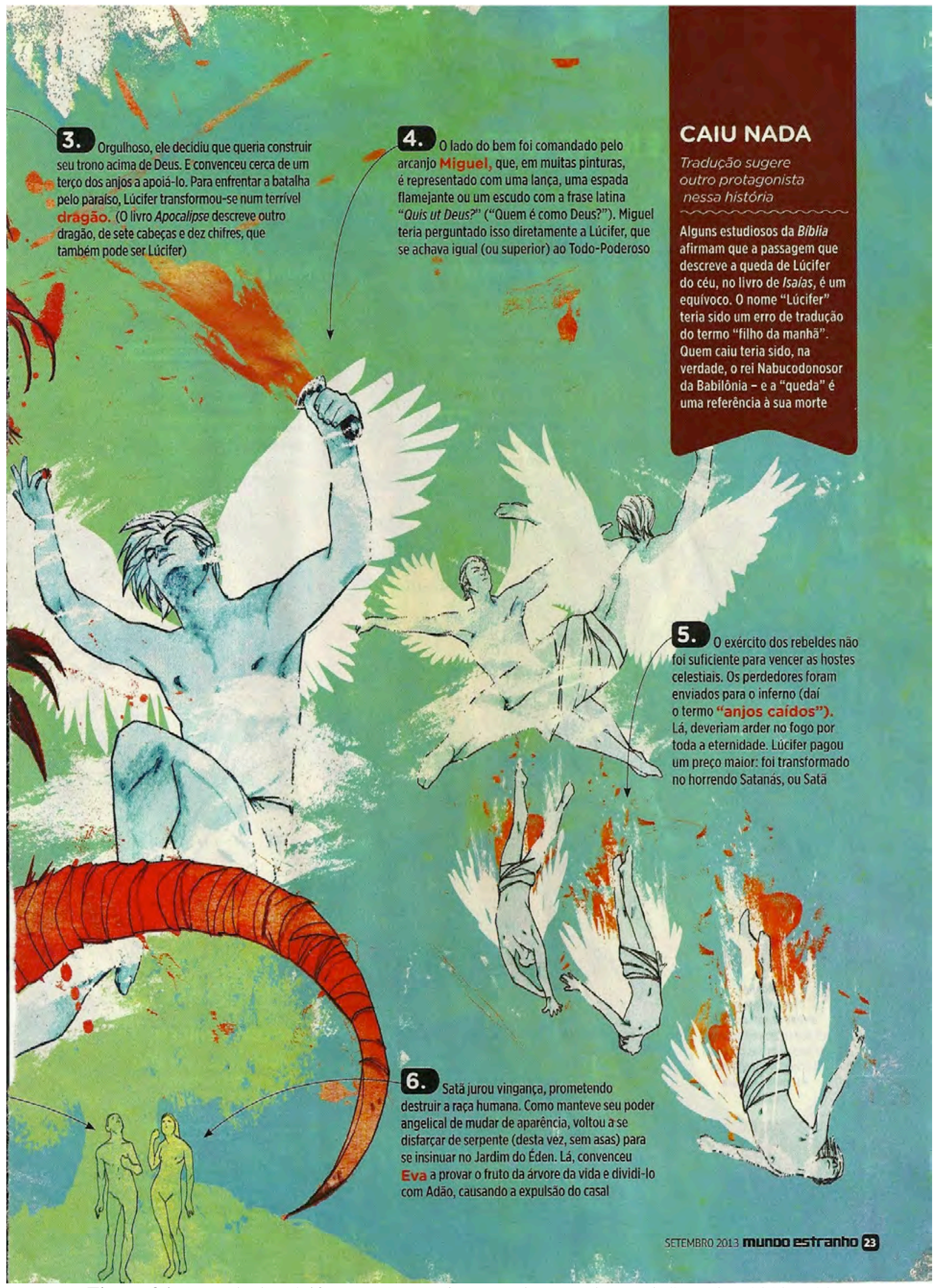

Figura 36: A queda de Lúcifer (cont.) - Revista Mundo Estranho - Ed. Setembro 2013, p.23 
Segundo Leslie Jones, historiadora da arte, a maneira mais fácil que os artistas encontram para estabelecer a diferença entre o anjo bom e o anjo mau é algo muito simples: mudam-se as cores, colocam-se chifres, deixam os olhos salientes e por vezes desenham uma cauda. A partir daí a figura torna-se diabólica e os demônios invocam terror e medo.

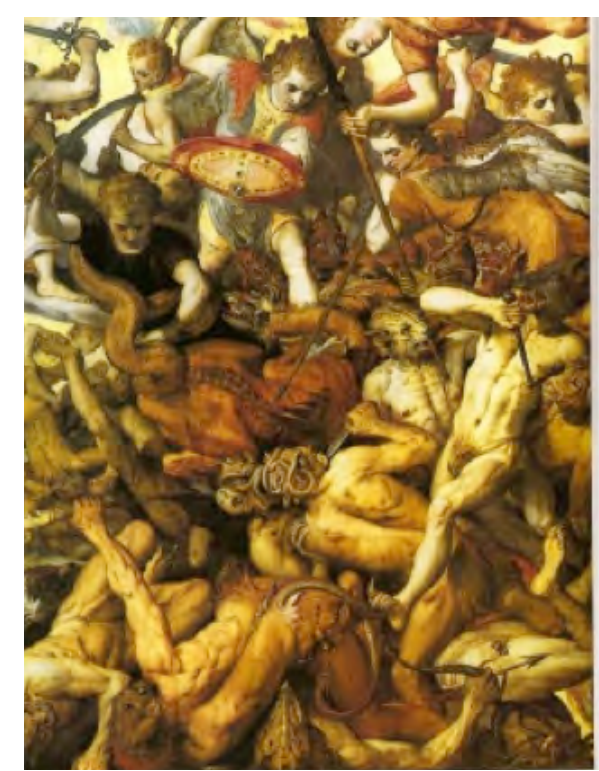

Figura 37: A queda dos Anjos - Frans Floris - 1554 - Koninklijk Museum voor Schone Kunsten, Antwerp ${ }^{38}$.

Mas os anjos bons também podem ser tão assustadores quanto os anjos maus. Quando as mulheres visitaram a sepultura de Cristo após a ressureição, encontraram-na vazia com os anjos tomando conta dela. A primeira coisa que os anjos disseram foi: "Não fiquem com medo!"

Há um motivo para que as pessoas tenham medo dos anjos, pois não é sempre que eles trazem boas notícias. Eles podem ser assustadores. Os bons podem ser assustadores e os maus encantadores. Interpretações erradas para isso é que não faltam. Os Hell's Angels ${ }^{39}$, por exemplo, nada têm a ver com uma filosofia ou doutrina satânica, nem a nada relacionado a essa parte complexa da sociedade.

Os anjos são um produto da imaginação teológica, da imaginação cultural, da imaginação mítica e da imaginação artística. Tudo combinado em uma rica mistura. Existem anjos com quatro cabeças, seis asas e múltiplos olhos, além da imagem mais constante e conhecida de todos: o anjo de rosto gracioso e infantil, principalmente aqueles que decoram o Dia dos Namorados e até cartões de Natal.

\footnotetext{
${ }^{38}$ Disponível em: <http://www.wga.hu/frames-e.html?/html/f/floris/frans/index.html> Acesso em: 10/05/14

${ }^{39}$ Hells Angels trata-se de um clube de motociclistas, cujos membros tipicamente são homens e pilotam motos Harley-

Davidson. Seu principal lema é: "Quando fazemos direito, ninguém lembra. Quando erramos, ninguém esquece"
} 
Essas criancinhas perfeitas do Renascimento Romano frequentemente são retratadas como jovens alados, que acertam os corações de jovens casais apaixonados. "Aliás, na tradição cristã, os anjos são muitas vezes representados como crianças, em sinal de inocência e de pureza." (CHEVALIER, 1994, p.302)

Durante a Renascença, os anjos eram frequentemente retratados como crianças. Todos os artistas se esforçavam para criar imagens com um ideal de beleza e as crianças eram vistas como a personificação da perfeição física. Proporcionalmente, eram perfeitas para representar esse ideal de beleza, pois a:

“(...) infância é um símbolo de inocência: é o estado anterior ao pecado e, portanto o estado edênico, simbolizando em diversas tradições pelo retorno ao estado embrionário, em cuja proximidade está a infância. Infância é símbolo de simplicidade natural, de espontaneidade(...)." (CHEVALIER, 1994, p.302)

Os músculos eram menos proeminentes. Os artistas conseguiam obter efeitos delicados com luz e sombra, além disso as crianças representam a síntese da inocência e da ternura em harmonia com a iconografia dos anjos.

O Cupido é o mais famoso desses pequenos anjos. Ele é retratado como uma criança alegre, inocente e travessa, mas que carrega uma arma mortal. $\mathrm{O}$ detalhe mais perigoso dessa representação é o arco e flecha. Eles podem ser usados para atravessar o coração de qualquer pessoa e fazer isso de uma maneira imperceptível, porque não temos consciência de que uma criança tenha esse poder e mais uma vez tem relação com a mitologia. Elemento de perigo e malícia, podemos notar que o anjinho está sempre sorrindo, ou seja:

\begin{abstract}
"O fato de Eros ser uma criança simboliza, sem dúvida, a eterna juventude de um amor profundo, mas também uma certa irresponsabilidade. Em todas as culturas, a aljava, o arco, as flechas, a tocha, os olhos vendados significam que o Amor se diverte com as pessoas de que se apossa e domina, mesmo sem vê-las (o amor, não raro, é cego), ferindo-as e inflamando-lhes o coração. $O$ globo que ele, por vezes, tem nas mãos, exprime sua universalidade e seu poder." (BRANDÃO, 1991, Volume I, pág. 357)
\end{abstract}

Os anjinhos meigos que conhecemos são na verdade querubins, a 2a. classe mais alta dos anjos. Nas sagradas escrituras, foram eles que receberam a missão de guardar o Jardim do Éden depois que Adão e Eva foram expulsos, algo nada próprio para crianças. Já os 
serafins e querubins eram constantemente retratados com dois, três ou quatro pares de asas, mas os artistas enfeitaram e adaptaram a forma, a função e os tipos de anjos conforme tinham vontade:

"Os anjos de seis asas, os serafins (literalmente: os Ardentes), circundam o trono de Deus; cada um deles tem seis asas: duas para cobrir o rosto (por medo de ver Deus), duas para cobrir os pés (eufemismo para designar o sexo), e duas para voar (Isaías, 6, 1-2)." (CHEVALIER, 1994, p.60)

O surgimento destes seres angelicais pode ser encontrado em religiões diversas como por exemplo no Cristianismo, desde o Antigo até o Novo Testamento; na Torá, livro sagrado do Judaísmo e no Budismo, acreditavam que tais entes alados pudessem ser tanto benéficos e amistosos com as pessoas, quanto maléficos e hostis, sendo caracterizados como seres que proporcionam a relação entre o campo terreno e o espaço divino e também celestial. Problematizados e principalmente apresentados pela História da Arte, esses seres foram representados como figuras aladas dotadas de preceitos divinizados que nos fascinam ainda hoje.

Através de suas diferentes representações, os anjos aproximaram-se dos seres humanos como símbolos de fé e auxiliaram durante séculos na atualização dos mitos que, com o passar dos anos, buscaram sempre aproximar sua significação à facilidade de comunicação com a população da época, fossem estes seus objetivos com intuito mitológico, religioso ou simplesmente histórico, principalmente como mensageiros e também a luta eterna do bem contra o mal. 


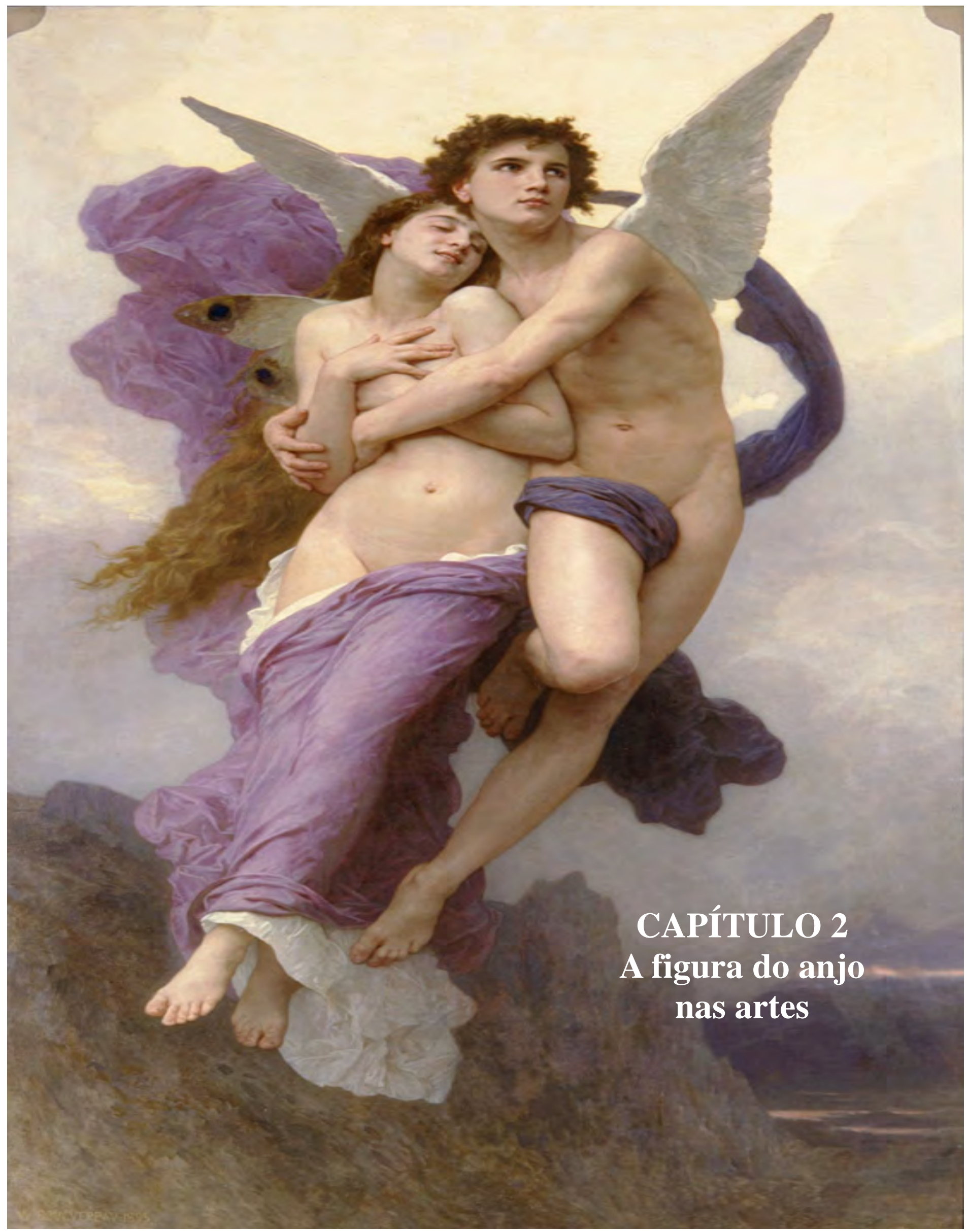




\section{CAPÍTULO 2}

\section{A figura do anjo nas artes}

Os anjos sempre foram fontes de inspiração para os artistas, estes buscavam através da construção imagética dessas criaturas aladas ilustrar em textos, pinturas ou esculturas a intermediação existente entre o celeste e o terreno. Fortemente ligados à arte e à religião, estas imagens aladas sempre estiveram constantemente retratadas em diversas culturas da humanidade.

O surgimento simbólico de tais seres visava ser o espelho do que fosse correto como atitude humana mirando o coletivo e nortearia o propósito de vida como reflexo de tudo aquilo que fosse divino e exemplar. Porém, tal aparição só ganhou força além de sua representação quando passou a ser citado em registros de crenças e religiões, já que o anjo, sendo um ser intermediário entre o céu e a terra e na impossibilidade de dar a Deus uma imagem que fosse corpórea ou descrita visualmente, seria o mensageiro, portador de suas notícias.

Neste ponto, o Concílio de Nicéia em 325 d.C. foi de grande auxílio ao declarar a crença nos anjos como parte do dogma. Algo que mais tarde, em 343 d.C., o Sinodo de Laudicéia, condenaria a adoração destes mesmos seres celestiais considerando o culto a eles idolatria. Somente tempos depois, já na Idade Média, os anjos recuperariam sua força imagética graças a esta mesma Igreja Cristã, em que:

“(...) com a chegada da era cristã, os anjos tornaram-se substâncias incorporais, inteligentes, superiores à alma do momento. A Igreja ensina que os anjos foram criados num estado de felicidade e de graça, mas com a liberdade de escolher entre o Bem e o Mal" (NÉRET, 2003, P.13).

A forma visível destes seres celestiais só se fez permitida com base na correlação e paridade de significações através de imagens retratadas e reproduzidas por artistas. Isto porque a arte sempre permitiu a composição, concepção, criação, elaboração, estruturação e idealização de todos os sentidos e possibilidades, ilustrando no atravessamento do tempo os distintos aspectos possíveis permitidos como características para este mito alado. 
Ao serem representados imageticamente na História da Arte, os anjos nos permitem ingressar em um infinito campo de análises estéticas, sejam como construção divina ou como criaturas aladas dotadas de preceitos religiosos.

Durante os três primeiros séculos do Cristianismo, a representação dos anjos não era permitida, e é interessante que até o século $X$, os anjos na arte eram curiosamente vestidos (LEWIS, 1999, p.166). Vale ressaltar que, ainda na Idade Média, não há uma estética propriamente dita, pois:

"A arte confunde-se nessa época, por um lado, com o ofício, e, por outro lado, com a contemplação divina que leva ao paraíso e que é, também ela, utilitária. Mas, nesta antinomia entre estética escolástica e a estética moderna admitida, há, devemos reconhecer, um começo do problema. O belo é constantemente atraído para a teologia e a teoria da arte é constantemente atraída para a técnica. Entre a teoria do belo e a teoria da arte, os dois troços de estética tomista não conseguem juntar-se"

( BAYER, 1995, p. 95)

É quando no período Gótico, surge Giotto, considerado o primeiro gênio da arte renascentista italiana, um dos primeiros artistas a conseguir uma representação dos anjos em uma das mais comoventes obras da História da Arte. Bastante realista, possui "uma arte de síntese e simplificação, de estilização, não de verismo. (...) Não pinta a imagem das coisas, mas o signo das coisas" (BAYER, 1995, p.96). Em uma de suas principais obras, "A Lamentação", exposta na Capella degli Strovegni em Paduá na Itália, que se permite observar tais características estéticas.

\footnotetext{
"Os anjos também são retratados na pintura de Giotto (...), em que introduziu um elemento absurdo representando pequenos anjos extremamente humanos rasgando seus peitos em desespero. (...) o lamento do anjo no céu tende a se expandir além de todas as proporções razoáveis se comparado com o pequeno e compacto grupo na área inferior ao redor do crucificado". (LEWIS, 1999, p. 166)
}

Nela são retratados vários anjos, espalhados por um céu azul, assistindo impotentes à cena abaixo com grande pesar. Com os corpos amplamente cobertos e contorcidos pela amargura, rezam ou choram, desconsolados, o desespero dos seres alados diverge da cena taciturna que ocorre logo abaixo. 

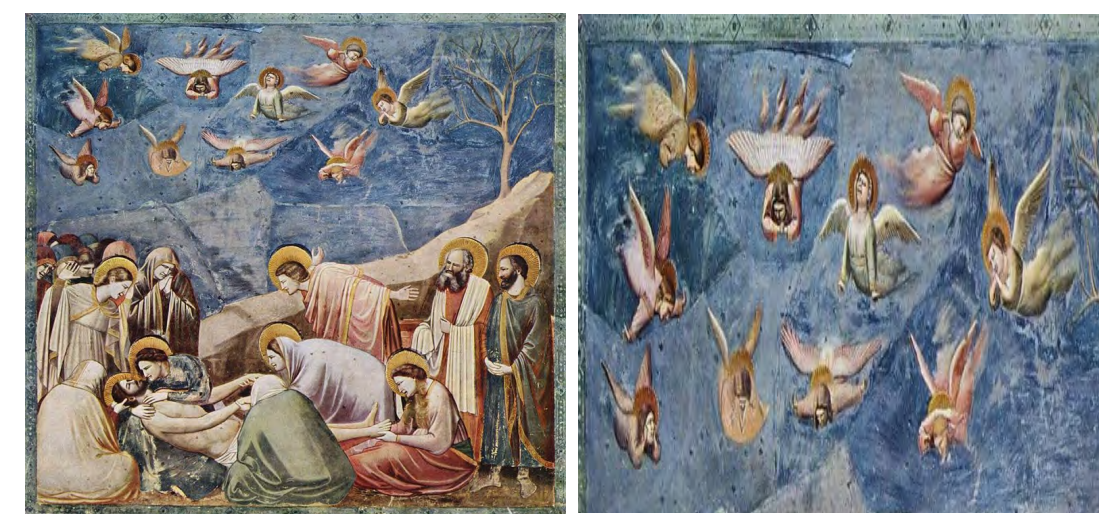

Figura 38: A lamentação (quadro e detalhe) - Giotto di Bondone - Capella degli Strovegni - Paduá ${ }^{40}$

O pintor Giovanni da Fiesole, nascido Guido di Pietro Trosini, porém mais conhecido como Fra Angelico, foi beatificado pela Igreja Católica, sendo considerado o artista mais importante da época do Gótico Tardio ao início do Renascimento.

Fra Angelico desenvolveu um estilo singular em seus afrescos, utilizando em suas obras cores claras e suaves, além do uso da luz como uma intenção estética. Obteve sucesso ao representar anjos como criaturas absolutamente sobrenaturais, sem nenhuma semelhança aos humanos. Enquanto seus anjos possuíam asas coloridas e quase sem exceção feições femininas, apesar da crença fortemente mantida de que os anjos eram assexuados, os outros mestres da época geralmente os representavam como rapazes bonitos ou crianças alegres. Tais características são melhor percebidas em uma de suas mais famosas obras, “A Anunciação", afresco que pode ser apreciado no corredor do convento de San Marco, onde "O anjo é decididamente feminino, com asas pintadas com cores do arco-íris e mãos gentilmente cruzadas, sem o lírio ou o cetro normalmente representados" (LEWIS, 1999, p. 15)

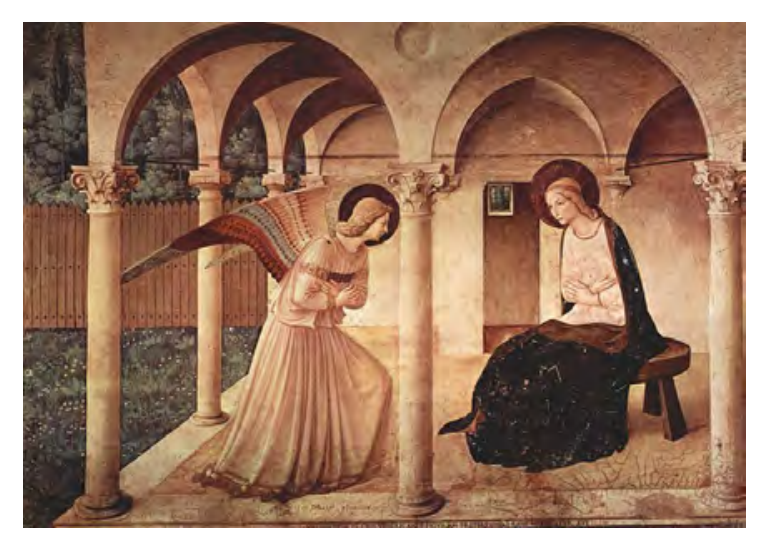

Figura 39: A Anunciação - Fra Angelico - Convento de San Marco - Firenze ${ }^{41}$

\footnotetext{
${ }^{40}$ Disponível em: <http://pt.wikipedia.org/wiki/Giotto_di_Bondone\#/media/File:Giotto_di_Bondone_009.jpg> Acesso em $07 / 05 / 14$
} 
O Renascimento, que floresceu em toda a Europa Ocidental, não se limitou apenas à Itália, embora tal país seja confundido como o berço deste movimento. Por tal razão, sempre vem à tona a comparação entre as obras de Jan Van Eyck e Fra Angelico.

O primeiro, pintor flamenco, assim como Fra Angelico, pintor italiano, também retratou a Anunciação. Apesar de ambos terem tido o mesmo entendimento de tal relato bíblico, foram capazes de estabelecer sua individualidade, e o que mais chama a atenção são as asas coloridas dos seres celestiais em suas obras.

Vale ressaltar que ambos possuíam estilos distintos, visando concordar e adequarse com as preocupações e interesses da época, levando em consideração o local em que viviam. Sendo um dos quadros mais belos de Jan Van Eyck, a Anunciação possui detalhes realistas como a espantosa riqueza na roupa do anjo Gabriel, bem como os detalhes das cenas bíblicas pintadas nos ladrilhos do chão. Além disso, notamos a desproporção das figuras em relação ao tamanho da igreja.

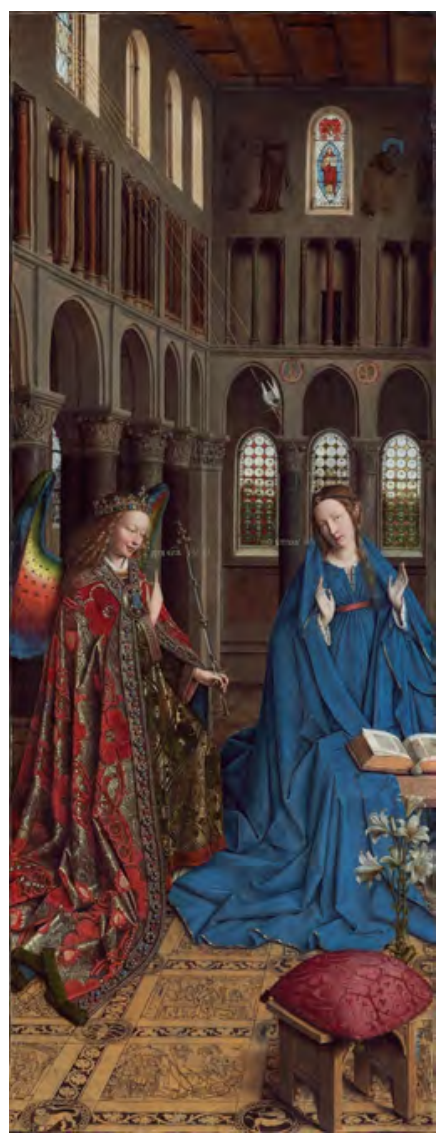

Figura 40: A Anunciação - Jan Van Eyck - The National Gallery of Art - Washington ${ }^{42}$

\footnotetext{
${ }^{41}$ Disponível em: <http://www.wga.hu/frames-e.html?/html/a/angelico/09/corridor/annunci.html> Acesso em 10/05/14

${ }^{42}$ Disponível em: <http://www.nga.gov/content/ngaweb/Collection/art-object-page.46.html> Acesso em 10/05/14
} 
Porém vale lembrar que a presença de imagens tão belas nas artes da Idade Média nem sempre foram permitidas. No período Românico, diferentemente do "pensamento grego, que consistia no equilíbrio, na unidade entre o sujeito e o objeto, não só autorizava como solicitava uma estética” (BAYER,1995, p.86), permitiu que a concepção cristã de arte utilizasse de uma estética "seguindo as prescrições e as concepções do neoplatonismo que levavam à morte de tudo o que era sensível e sensual no homem e onde é preciso matar em si a vida sensível, sensual, e matar o prazer sentido no belo” (BAYER,1995, p.86).

Basta que para isso observemos o quadro A anunciação exposto abaixo, no qual fica claro a rigidez e imobilidade da obra e utilizados na época, em que neste caso, na arte medieval, o anjo ao estar de perfil com a mão direita estendida, significava o ato de falar e permite que:

Se, ao observar essa iluminura, esperarmos a vívida ilustração de uma cena real, talvez fiquemos desapontados. Mas se nos lembramos, uma vez mais, de que o artista não estava empenhado numa imitação de formas naturais e se preocupava tão-somente com a disposição de tradicionais símbolos sagrados, que era de tudo o que ele necessitava para ilustrar o mistério da Anunciação, então deixaremos de sentir a falta daquilo que o artista nunca pretendeu nos dar" (GOMBRICH, 1999, p.180 e 181)

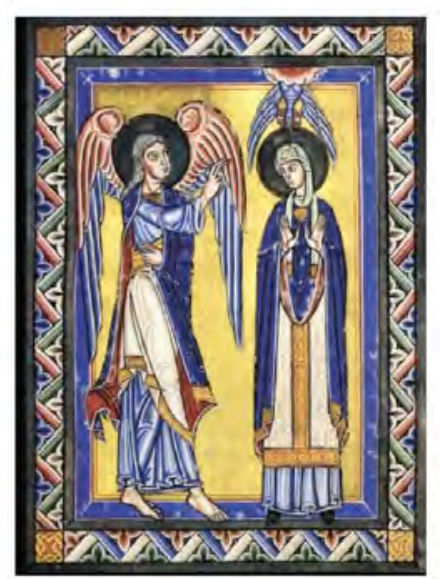

Figura 41: A Anunciação de um evangelho manuscrito suábio. Württembergische Landesbibliothek, Stuttgart ${ }^{43}$

Após este período da Idade Média, a concepção das obras baseou-se somente no que fosse santo e aniquilava tudo o que fosse ou emitisse qualquer significado sensual ou animal e a arte passou a possuir finalidade puramente anestésica, diante da inexistência com a preocupação com o que fosse belo, visando fins apenas utilitários.

\footnotetext{
${ }^{43}$ Disponível em: <http://www.historialivre.com/revistahistoriador/espum/rivadavia.pdf > Acesso em 11/05/14
} 
É quando, em sentido adverso dessa corrente de pensamento, surge o Renascimento, glorificando a beleza e permitindo que a arte transformasse as obras dos artistas da época em exemplos de magnificação do ser humano, sendo representados por inúmeros pintores da época, com destaque para os italianos Botticelli, Leonardo Da Vinci, Michelângelo e Rafael de Sanzio.

\subsection{Sandro Botticelli}

Abordando conteúdo mitológico em muitas de suas pinturas, Sandro Botticelli ficou conhecido por suas obras ricas em referências alegóricas à Antiguidade, com destaque para "O Nascimento de Vênus", com a representação da chegada da deusa a ilha de Chipre. Financiado pela família Médici, grandes mecenas da época do Renascimento e os grandes responsáveis pelo crescimento da arte neste período, esta é sem dúvida uma das obras mais famosas e apreciadas do mundo da arte e hoje exposta na Galleria Uffizi em Florença.

Tal obra, apesar da pouca quantidade de elementos visuais, mostra-se complexa em sua interpretação. Baseando-se na "Metamorfose de Ovídio" como tema, importante literatura latina, possui também como referência clara à "Estâncias", obra poética de Agnolo Poliziano, poeta contemporâneo de sua época.

Botticelli permite-nos encontrar em suas obras dois temas principais: o Cristianismo e a Antiguidade grega. Não raro nos chama atenção os corpos esguios leves e desprovidos de força, retratando suavidade e graça. Para ele, o ideal de beleza estava aliado ao ideal cristão e por essa razão, as figuras humanas em suas pinturas são belas porque buscam manifestar a graça divina, ao mesmo tempo em que também são melancólicas porque julgam que perderam tal dom de Deus.

A obra de Botticelli permite-nos perceber a ligação desta obra com o chamado neoplatônico, corrente de pensamento que buscou ligar o patrimônio cultural grego e romano ao Cristianismo, quando, no significado filosófico veria o nascimento do amor e da beleza espiritual como uma força motriz da vida. Força motriz esta, representada na obra por figuras aladas que sopram uma concha, permitindo a deusa que desembarque em seu destino final protegida e possa receber o manto da serva que lhe aguarda à margem. 
A iconografia do Nascimento de Vênus propõe muitas fontes e interpretações, porém os especialistas em História da Arte e mais especificamente no estudo do período Renascentista concordam que a interpretação neoplatônica mais claramente articulada seria a realizada por Ernst Gombrich, como forma de melhor compreender a pintura durante os anos. Para Gombrich, Botticelli representou Vênus para que ela tivesse dois aspectos, primeiro, seria uma deusa terrena que despertaria nos humanos o amor físico e segundo uma deusa celeste que inspiraria o amor intelectual nestes mesmos humanos.

No entanto, apesar das leituras essencialmente pagãs, não se permite excluir da obra de Botticelli interpretações cristãs, vistas do ponto de vista religioso, em que a nudez da deusa sugere uma Eva antes da perdição e que após cair em pecado passa a vestir o manto terrestre da mortalidade e nesta interpretação, os anjos seriam os encarregados por esta expulsão. Porém, após desembarcar, já envolta em vestes terrenas, tornara-se a personificação da Igreja Cristã, que oferece um transporte espiritual de volta ao puro amor de salvação eterna.

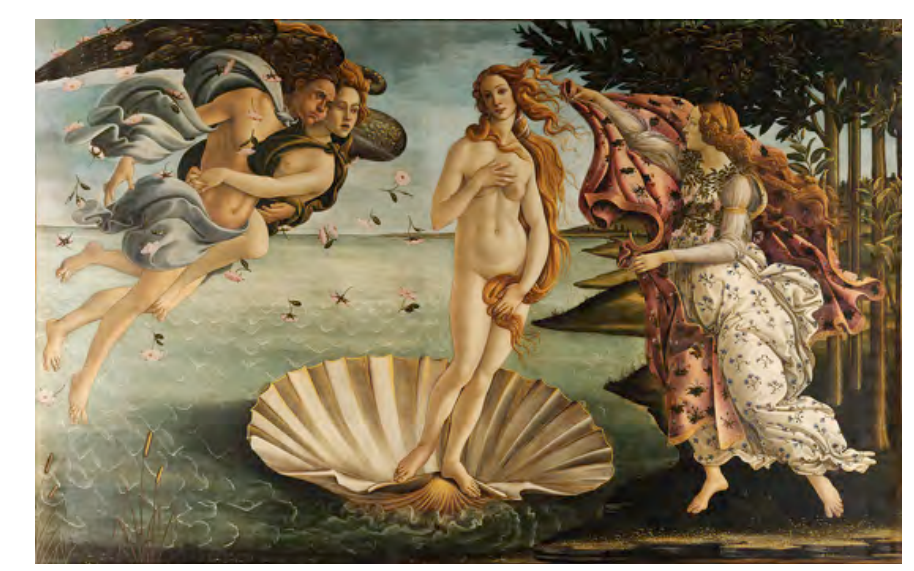

Figura 42: O nascimento de Vênus - Sandro Botticelli - Galeria Uffizi - Firenze ${ }^{44}$

\subsection{Leonardo Da Vinci}

O Renascimento, período caracterizado pela valorização da estética greco-romana e pelo resgate dos valores clássicos, como a beleza e a perfeição, através dos ideais humanistas, teve em Leonardo Da Vinci um de seus maiores representantes. Em um tempo, quando o homem buscava encontrar seu valor no mundo, edificando o conceito de

\footnotetext{
${ }^{44}$ Disponível em: <http://www.uffizi.org/artworks/the-birth-of-venus-by-sandro-botticelli > Acesso em 11/05/14
} 
antropocentrismo, este gênio da escola florentina, não dedicado apenas às artes plásticas como também à ciência, rascunhou com habilidade máquinas voadoras, produziu elaborados estudos sobre mecânica, anatomia e astronomia entre tantas outras áreas, tornando-se pesquisador em diversos campos do conhecimento humano.

Soube utilizar com maestria o uso de luz e sombra como forma de estimular a imaginação do observador de suas obras e seus estudos sobre perspectiva até hoje são considerados por muitos estudiosos da História da Arte como insuperáveis.

Famoso pelo domínio da técnica "sfumato", o uso de tons claros e escuros esfumaçados é conhecido por inúmeras obras, as que mais se destacam são a Mona Lisa e o Homem Vitruviano.

São quase inexistentes nas obras de Leonardo Da Vinci pinturas que englobem em seu teor anjos ou criaturas aladas. Porém, assim como com tantos outros pintores do passado, também é possível encontrar entre suas obras a sua "Anunciação", momento em que o Anjo Gabriel comunica a Virgem Maria a chegada de Jesus Cristo.

Pintada por ele entre 1472 e 1475, esta obra de Da Vinci permite-nos perceber várias das características estéticas e filosóficas do Renascimento, pois ao estudar sobre as asas dos pássaros, utilizando-se disto para pintar as asas do anjo, o fez com incrível precisão, o que denota justamente a preocupação da corrente de pensamento da época com a perfeição.

Ademais, trata-se de obra humanista, posto que em tal quadro, Maria não é representada de maneira submissa, compreendendo o papel da humanidade na vida de Jesus, e o anjo mensageiro Gabriel segura flores em uma de suas mãos, símbolo da virgindade e pureza de Maria.

Isto posto, demonstra-se que:

"A estética de Leonardo (...) é cheia de sensualidade mística. Mas é preciso que no artista haja um desejo não satisfeito e mesmo impossível de satisfazer: o racionalismo de Leonardo reserva um lugar à sensualidade (...) Duas vias, segundo ele, se abrem ao artista: a imitação da natureza ou a substituição da realidade por um ideal" (BAYER, , 1995, p.117) 


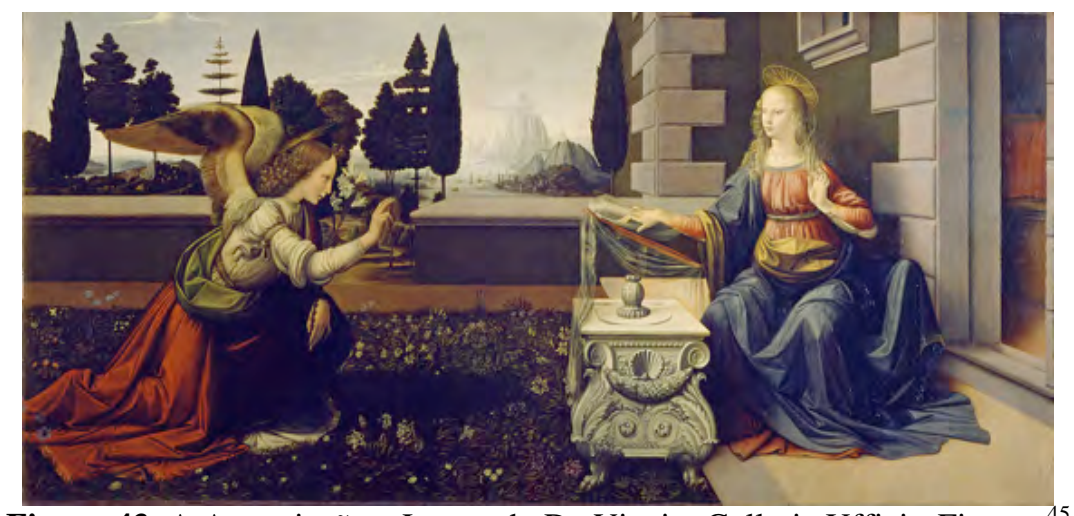

Figura 43: A Anunciação - Leonardo Da Vinci - Galleria Uffizi - Firenze ${ }^{45}$

\subsection{Michelângelo}

Assim como Leonardo Da Vinci, Michelângelo é considerado um dos artistas mais importantes da História da Arte. Apesar de não ter se dedicado apenas à pintura, mas também à arquitetura, à escultura e à poesia, foi na primeira que obteve seu mérito e genialidade reconhecidos.

Tamanha é sua relevância dentre os artistas surgidos durante o Renascimento que fora requisitado para retratar através de afrescos, adornos e ornamentos o interior da Capela Sistina no Vaticano a pedido do então Papa Júlio II.

Ao buscar identificar os anjos retratados por Michelângelo, duas de suas obras merecem maior crédito, para que se possibilite uma melhor análise no decorrer desta pesquisa.

A princípio, é necessário que abordemos "A Criação de Adão", na qual o autor da obra reproduz e representa Deus através de um senhor de barba envolto por um manto que compartilha com alguns anjos. Tal concepção baseia-se na mitologia greco-romana, e por tal razão seja uma das raras imagens de Deus como um ser de barbas brancas, fazendo alusão à Antiguidade Clássica, mais propriamente dito a Zeus ou Posseidon, visto que no passado e mais especificamente na Grécia, a barba era tida como atributo de gnose e sapiência. Ao representar Deus mirando Adão e estendendo seus braços a ele, Michelângelo quase permite que as mãos de Deus toquem as de Adão. Em meio a essa cena, há dentre tantos querubins um particularmente belo recostado sob o braço esquerdo de Deus contemplando toda a ação com demasiado interesse.

\footnotetext{
${ }^{45}$ Disponível em: <http://commons.wikimedia.org/wiki/File:Leonardo_da_Vinci_-_Annunciazione__Google_Art_Project.jpg > Acesso em 11/05/14
} 


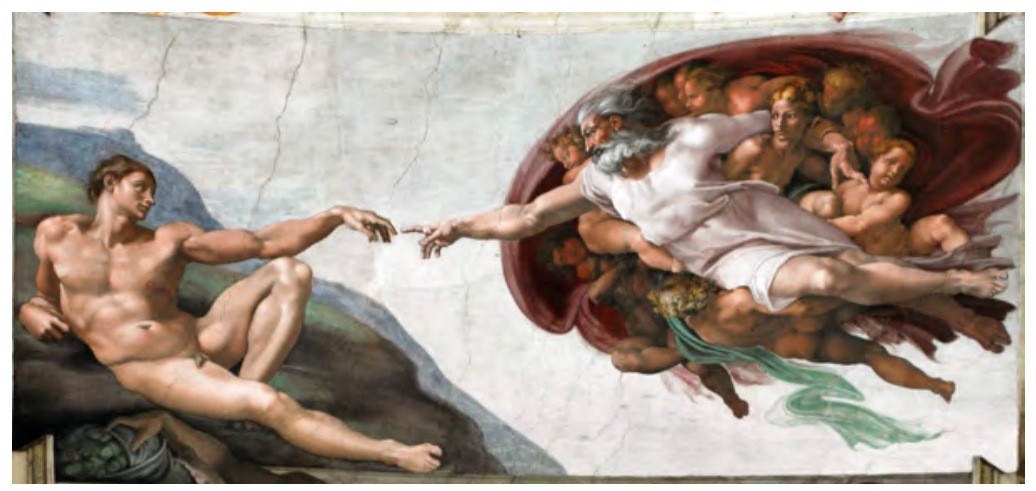

Figura 44: A Criação de Adão - Michelângelo - Capela Sistina - Vaticano ${ }^{46}$

Outra obra de suma relevância realizada na mesma Capela Sistina por Michelângelo é a cena do "Juízo Final". Nela está representada a filosofia da Contrarreforma, momento em que esta exercia a censura sobre qualquer visão diversa do Cristianismo, quando Jesus Cristo é apresentado como um juiz que, ao julgar, separa os bons dos maus e os anjos são coadjuvantes nesse processo como que para qualificar atributos e predicados.

Delimitado em quatro partes, este painel possui em sua parte superior anjos e querubins que ilustram as alegorias da paixão de Cristo. Logo abaixo surgem querubins responsáveis por soar a última trombeta para despertar os mortos, no qual destacam-se especialmente dois anjos com livros abertos entre as mãos, em que os julgados leem sua vida passada que selou seu destino.
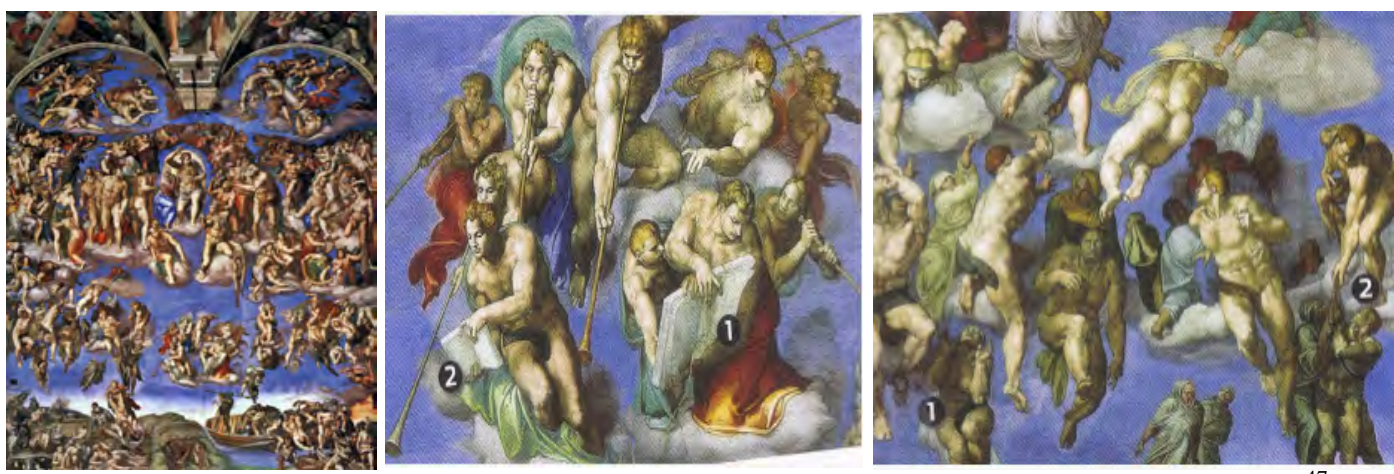

Figura 45: O juízo final (quadro e detalhes) - Michelângelo - Capela Sistina - Vaticano ${ }^{47}$

Ao analisarmos a atribuição estética dada às obras citadas anteriormente, é possível afirmar que “(...)as figuras do anjos são nuas, masculinas em aparência e sem asas. De fato, os anjos, não são diferentes dos humanos. Michelângelo escolheu esse tipo de visual para mostrar a íntima associação que os anjos têm com o homem”. (LEWIS, 1999, p. 262)

\footnotetext{
${ }^{46}$ Disponível em: <http://mv.vatican.va/3_EN/pages/x-Schede/CSNs/CSNs_V_StCentr_06.html> Acesso em 17/05/14

${ }^{47}$ Disponível em: <http://commons.wikimedia.org/wiki/File:Michelangelo,_Giudizio_Universale_02.jpg > Acesso em $17 / 05 / 14$
} 


\subsection{Rafael Sanzio}

Estudioso dos trabalhos de Leonardo da Vinci e Michelângelo, Rafael destacou-se pela delicadeza dos traços de suas obras, pela conciliação ao retratar o paganismo e o cristianismo e pelo equilíbrio das cores e linhas. Tornou-se célebre pintor de madonas, tipos ideais de beleza feminina e conseguiu em seus quadros aplicar com sensibilidade princípios matemáticos e geométricos, demonstrando um enorme senso de ordem e segurança, dado que os elementos retratados em suas obras eram dispostos em espaços amplos e com equilíbrio simétrico.

Assim como seus antecessores, Rafael também teve retratados anjos que posteriormente se tornariam célebres em diversas pinturas e principalmente nos afrescos do Vaticano, "os anjos de Rafael, especialmente em seus últimos trabalhos, não têm sexo, são espirituais, graciosos e, ao mesmo tempo, a personificação da inteligência e do poder" (LEWIS, 1999, p. 312).

Tais características estéticas ficam realçadas na representação do arcanjo Miguel ao abater Lúcifer, obra criada a pedido de Lorenzo de Medici. Nela, é possível notar que o pubescente e formoso anjo páira no ar, tocando levemente com seus pés o demônio com chifres e rabo, porém ainda com asas, visto que se trata de um anjo caído. A expressão do anjo, apesar de séria, mantém-se serena enquanto fita seu oponente contorcendo-se. Miguel segura sua lança dourada e, ao retratá-lo, Rafael permite-nos visualizar suas asas abertas parecendo brilhar. 


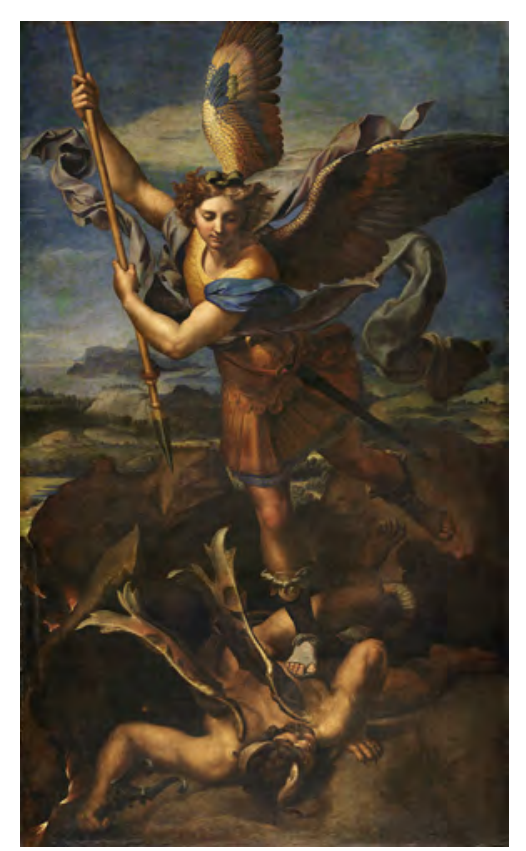

Figura 46: O grande São Miguel - Rafael Sanzio - Museu do Louvre - Paris ${ }^{48}$

Porém não somente de imagens poderosas é produzido o portfólio das grandes obras de Rafael Sanzio, como também de algumas reflexivas. Um de seus mais famosos quadros, a "Madona Sistina", acabou por permitir que os querubins contemplativos ali retratados se tornassem os protagonistas e não mais os coadjuvantes como fora intitulada a obra.

Apesar de retratar toda uma imagem sacra, nela o que se destaca são os dois pequenos querubins presentes na parte central inferior da tela e que assistem descontraidamente à cena representada logo acima. $\mathrm{O}$ relevante desta cena é que a presença destes seres alados acaba por delegar certa realidade à obra, convertendo a concepção de que para que algo seja sacro deva necessariamente ser austero e sisudo. Sua presença na obra nos leva a imaginar se tais anjos estariam atentos ou alheios aos acontecimentos ali retratados. Além disso, permite-nos questionar se seriam anjos ou meninos-pássaros em virtude da cor escura de suas asas, alterando a já conhecida alva estética angelical.

\footnotetext{
${ }^{48}$ Disponível em: <

http://commons.wikimedia.org/wiki/File:Le_Grand_Saint_Michel,_by_Raffaello_Sanzio,_from_C2RMF_retouched.jpg> Acesso em 17/05/14
} 

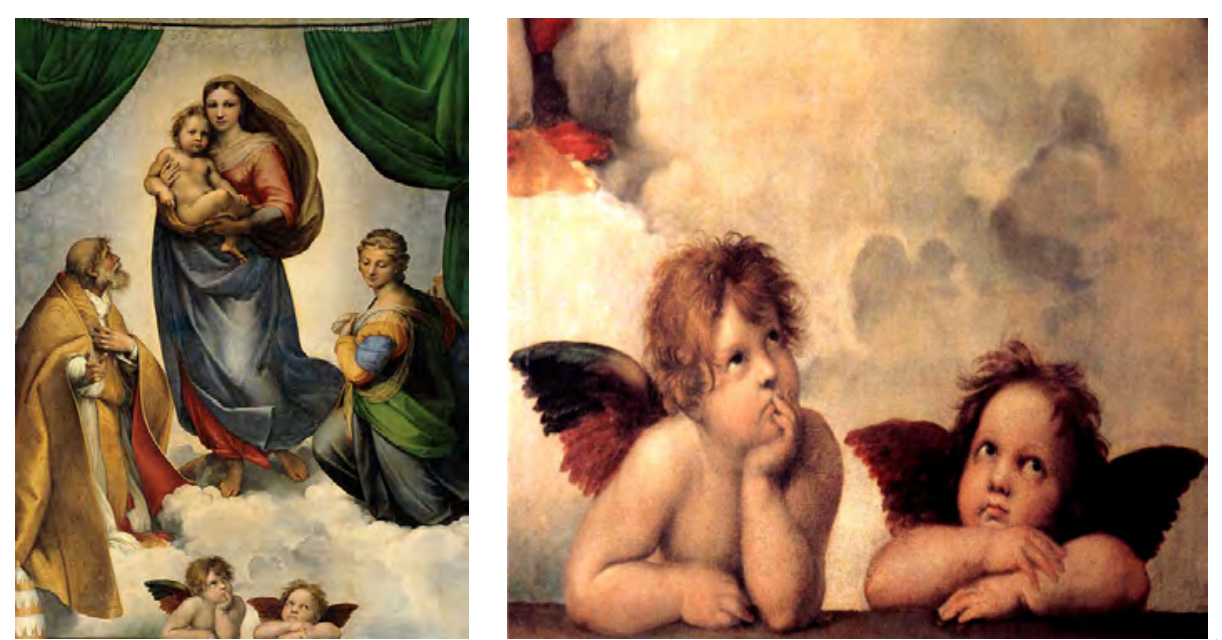

Figura 47: Madona Sistina - Rafael Sanzio - Gemäldegalerie Alte Meister - Alemanha ${ }^{49}$

\subsection{Albrecht Dürer}

Contemporâneo de Rafael Sanzio, porém sagrando-se no Renascimento Nórdico, a estética de Albrecht Dürer antecipou-se ao movimento Barroco ao divergir de qualquer outro artista de sua época, demonstrando em suas obras o descontentamento contra as instituições da Igreja e retratando as visões fantásticas que possuía sobre os eventos apocalípticos e proféticos em xilogravuras.

Para representar o apocalipse, Dürer buscava desprezar as já conhecidas poses tradicionais repetidamente usadas para demonstrar o combate contra um inimigo mortal, que visavam sempre retratar o herói de modo elegante e de compostura. Tal análise é possível ao vislumbrarmos uma de suas mais famosas obras na qual São Miguel acaba por abater o dragão. Nela:

“ O São Miguel de Dürer não faz pose. É de uma seriedade terrível(...). À sua volta estão as hostes de outros anjos guerreiros, combatendo como espadachins e arqueiros contra monstros diabólicos cuja aparência fantástica desafia qualquer descrição. ” (GOMBRICH, 1999, p.345)

\footnotetext{
${ }^{49}$ Disponível em: <http://www.wga.hu/html_m/r/raphael/5roma/2/03sisti.html> Acesso em 17/05/2014
} 


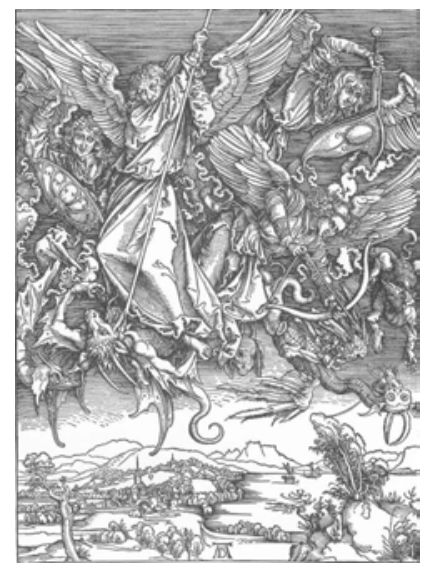

Figura 48: São Miguel lutando contra o dragão - Albretch Dürer - 1498 - Staatliche Kunsthalle, Karlsruhe ${ }^{50}$

Apesar de renascentista, torna-se nítida a antecipação da estética barroca nas obras de Albretch Dürer quando se observa o olhar prostrado do anjo presente em gravura de metal "Melencolia I". Nesta alegoria de Dürer, percebe-se a caracterização da imagem do anjo como ser divino, porém melancólico e dotado de atributos humanos. Sua expressão é provocada pela impassibilidade e apatia da sociedade diante de sua existência, em que os objetos da vida encontram-se dispersos ao chão, absortos à sua função protetora, como descreve Walter Benjamin ao estudar tal xilogravura:

"Essa figura antecipa sob vários aspectos o Barroco. (...) o melancólico é invejoso, triste, avaro, ganancioso, desleal, medroso e de cor terrosa, e o humor melancholicus, o 'complexo menos nobre'. (...) Surgem detalhes exóticos, como a inclinação do melancólico para longas viagens. (...) $O$ olhar voltado para o chão caracteriza o saturnino, que perfura o solo com seus olhos. ” (BENJAMIN, 1984, p.164-175)
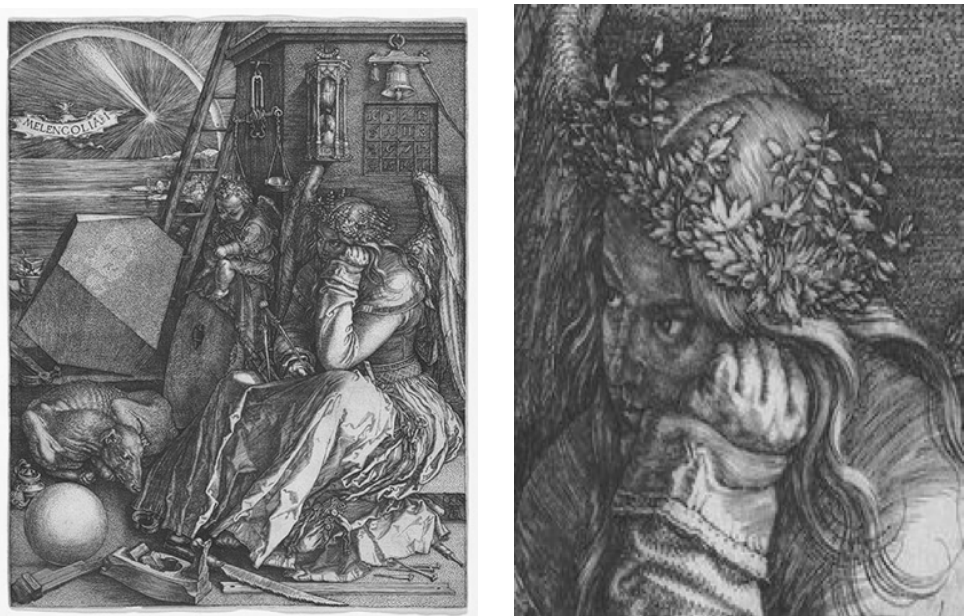

Figura 49: Melencolia I - Albretch Dürer - 1514 - Xilogravura - Anhaltische Gemäldegalerie Art Gallery ${ }^{51}$

\footnotetext{
${ }^{50}$ Disponível em: <http://www.kunsthalle-karlsruhe.de/en/the-collection/drawings-and-prints.html> Acesso em 17/05/2014

${ }^{51}$ Disponível em: < http://commons.wikimedia.org/wiki/File:Melencolia_I_(Durero).jpg > Acesso em 17/05/2014
} 


\subsection{O Barroco Brasileiro: os anjos de Aleijadinho e de Mestre Ataíde}

Surgido na Itália no século XVII e espalhando-se por toda a Europa, foi posteriormente no Brasil que o Barroco destacou-se por suas características acentuadas. Conceito vasto e complexo ainda hoje estudado por muitos teóricos da História da Arte, o Barroco manifestou-se como corrente em um período em que se propunha conciliar dois valores distintos, a espiritualidade e teocentrismo oriundos da Idade Média com o racionalismo e antropocentrismo vivenciados no Renascimento, levando os artistas da época a manifestarem-se artisticamente com o objetivo de atrair os fiéis de volta às instituições religiosas católicas, através do deslumbramento e da emoção.

Com obras chanceladas pelo clero, por burgueses e pela monarquia, as obras deste período possuíam uma estética rebuscada, cheia de minúcias e expressavam as emoções da vida e do ser humano. Através da utilização de muitas curvas e dobras, fortes contrastes de luz e sombra, o Barroco buscou estar muito próximo do naturalismo, quando as imagens dos objetos e das pessoas eram retratadas o mais próximo do real, incluindo marcas do tempo e defeitos físicos.

Outro aspecto atribuído a esse período são as colocações abstratas das figuras e a maneira como são dispostas as cenas alegóricas nas composições, fazendo com que desta forma se imponha a estas, um caráter fantástico e uma resplandescência teatral de modo a aproximar os indivíduos do mundo celestial. Isto posto, “arquitetos, pintores e escultores foram convocados para transformar as igrejas em exibições grandiosas cujo esplendor $e$ glória quase nos cortam a respiração" (GOMBRICH, 1999, p. 436-437)

Heinrich Wölfflin, historiador da arte suíço, problematizou a estética barroca, discutindo e defendendo pressupostos que abordaram conceitos originados do Renascimento e do Barroco, dividindo-os em cinco categorias:

TABELA 2 - CONCEITOS ORIGINADOS DO RENASCIMENTO E DO BARROCO

\begin{tabular}{|c|c|}
\hline RENASCIMENTO & BARROCO \\
\hline Linear & Pictórico \\
\hline Plano & Profundidade \\
\hline Forma fechada & Forma aberta \\
\hline Pluralidade & Unidade \\
\hline Clareza & Obscuridade \\
\hline
\end{tabular}

Fonte: CARNEIRO, 2010, p. 33 - Tabela feita pela própria autora com base no texto consultado 
Influenciado pelo barroco português, o barroco brasileiro adquiriu atributos muito peculiares com o passar do tempo, caracterizando-se pela presença dos anjos.

Nesse período, notamos que os anjos são presença constante da ornamentação, constituindo um simbolismo figurativo e decorativo das igrejas, porém quase desaparecendo em meio ao excesso de elementos nos veios das talhas e pinturas. No entanto, mesmo em meio a tantos detalhes, percebemos que houve por parte dos artistas a preocupação da execução da obra artística de forma harmônica, conferindo às imagens sacras delicadeza e doçura, mesmo que algumas vezes apresentem desproporcionalidades.

O barroco brasileiro possui como seu principal representante o escultor Antônio Francisco de Lisboa, o Aleijadinho, cujas obras apresentam enorme caráter religioso, sendo na sua maioria produzidas em pedra-sabão ou madeira. Além dele, é possível citar seu contemporâneo, o pintor Manuel da Costa Ataíde, mais conhecido por Mestre Ataíde. Nas obras desses dois artistas, é possível notar as manifestações de fé junto à arte, mas de uma maneira única, como se pudesse vivenciá-las.

Apesar da fama de Aleijadinho, é Mestre Ataíde que se destaca de modo significativo para esta dissertação, visto que possuía uma forma estética muito peculiar e própria de representar anjos, santos e padroeiras, em que atribuía-lhes traços mestiços inconfundíveis, inserção de instrumentos do cotidiano e trabalhos de douramento em suas pinturas.

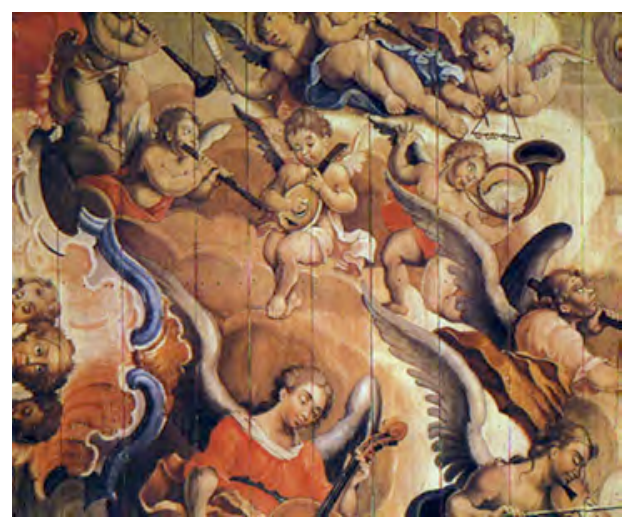

Figura 50: Ornamentação do teto da Igreja de São Francisco de Assis - Mestre Ataíde - Ouro Preto ${ }^{52}$

Sua obra mais famosa foi a ornamentação do teto da Igreja de São Francisco de Assis, em Ouro Preto, onde a estética diferenciada vai além das características mestiças, pois ao pintar a abóbada, homenageou seu amigo Aleijadinho, ilustrando o famoso "anjo coxo"

${ }^{52}$ Disponível em: <http://www.geocities.ws/copia_a/500anos5.html> Acesso em 17/05/2014 
empunhando um cajado. Além disso, representou Nossa Senhora de Porciúncula dando a esta as feições de sua esposa mulata Maria do Carmo.
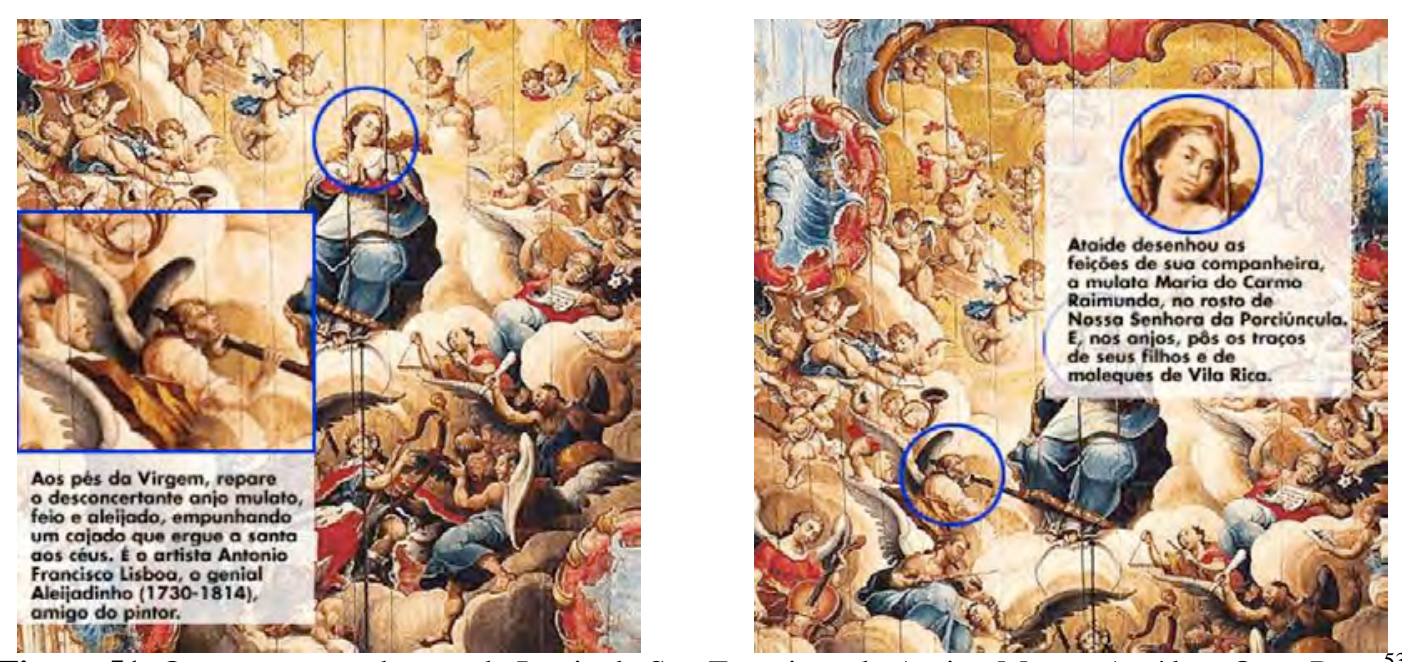

Figura 51: Ornamentação do teto da Igreja de São Francisco de Assis - Mestre Ataíde - Ouro Preto ${ }^{53}$

\subsection{A partir de Paul Klee: os anjos na Arte Moderna}

Notamos que a partir do Barroco e posteriormente na arte contemporânea, os anjos retratados alegoricamente passaram a apresentar esteticamente além de atributos humanos e realistas, também características mundanas. Isto permitiu a construção de uma relação deles com a história da humanidade. Foi como se questionassem todos os eventos, ocorrências e metamorfoses expressas e manifestadas pelos seres humanos na trajetória do mundo.

Isto posto, não há como não citar o "Angelus Novus" de Paul Klee como maior expoente para tal representação. O desenho produzido em 1920 utilizando nanquim, giz pastel e aquarela, surge em um momento em que o mundo passava por um percurso de transformações, compondo um mundo de aparência, a sociedade do espetáculo e é nesse momento que o anjo ressurge como fluxo do celestial para o terreno.

Nos tempos modernos, a imagem do anjo integra a condição humana, transformando este ser celestial em pujante potência próxima à vida humana, quando suas características transgridem os seres vistos até então como delicados, puros e perenes, o que nos faz crer que esses seres alados sempre estiveram presentes no imaginário e seu

\footnotetext{
${ }^{53}$ Disponível em: <http://www.geocities.ws/copia_a/500anos5.html> Acesso em 17/05/2014
} 
simbolismo sofreu mutações conforme a necessidade de sua relação tempo-espaço, permitindo que ressurja como sobrevivente no paradoxo do mundo que não mais o define como portador do bem ou do mal.

A obra de Paul Klee é justamente uma crítica a este progresso desordenado da sociedade. Busca manter o viço da tensão entre o humano e o divino. Por tratar-se de um mensageiro, representa também em sua mensagem o assombro divino diante de todo o progresso profano. E este anjo ao apresentar deformidades, demonstra em si esta relação existente entre estes dois polos.

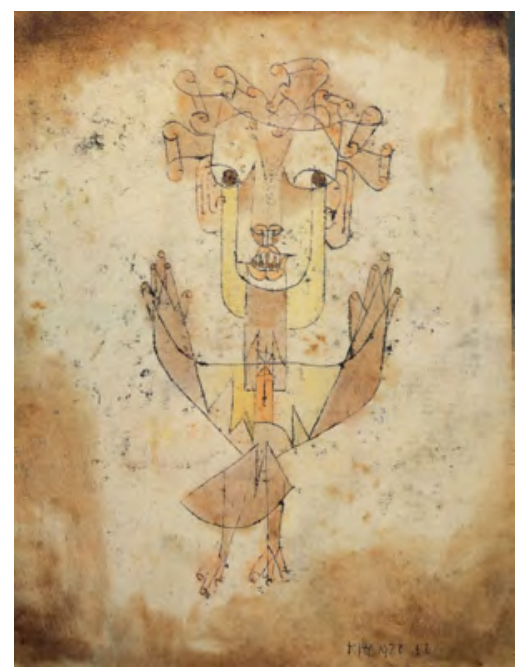

Figura 52: Angelus Novus - Paul Klee - 1920 - Israel Museum - Jerusalém ${ }^{54}$

O sociólogo e filósofo Walter Benjamin, que teve em seu poder a tela de Paul Klee durante muitos anos, auferiu êxito ao escrever em seu ensaio "Teses Sobre o Conceito de História", o seguinte sobre a tela:

"Há um quadro de Klee que se chama Angelus Novus. Representa um anjo que parece querer afastar-se de algo que ele encara fixamente. Seus olhos estão escancarados, sua boca dilatada, suas asas abertas. O anjo da história deve ter esse aspecto. Seu rosto está dirigido para o passado. Onde nós vemos uma cadeia de acontecimentos, ele vê uma catástrofe única, que acumula incansavelmente ruína sobre ruína e as dispersa a nossos pés". (BENJAMIN, 1984 , p. 226)

As distintas representações do anjo na arte contemporânea vão além do âmbito sacro. Apesar das imagens que compõem o repertório imagético da sociedade, retratando o anjo na maioria das vezes através de sua principal função, a de anjo da guarda ou mensageiro,

\footnotetext{
${ }^{54}$ Disponível em: < http://www.english.imjnet.org.il/Popup.aspx?c0=13336> Acesso em 18/05/2014
} 
ainda assim encontramos cada vez com maior frequência um ser alado mais mortal e mundano, caracterizado de modo a aproximar-se do que o homem atualmente se constitui.

Os anjos passaram a ser retratados de maneira imóvel ou apenas em partes, permitindo infinitas possibilidades de interpretações e estímulo dos sentidos. Expondo assim sua fragilidade e aproximando-os das atitudes humanas.

Damien Hirst, artista britânico, ao criar sua obra Anatomia de um anjo (2008), busca unir universos distintos: a condição humana e a essência celestial do anjo. Isso porque, ao construir um anjo que surge primeiramente de um bloco de mármore, proporciona a este uma durabilidade no tempo e no espaço, ao mesmo tempo em que demonstra sua delicadeza e fragilidade ao expor seus órgãos.

De postura desajeitada, assim como um ser humano pode vir a ser, permanece arraigado à pedra impossibilitado de exercer sua função celestial e primeira: voar. Ao mesmo tempo em que seu interior é similar ao dos humanos, com órgãos à mostra, através de articulações orgânicas, o interior do anjo é sua função e essência, permanecendo na condição de mito. Há nesta obra a intenção de despertar no espectador a compreensão do que vem a ser real ou irreal, ou buscar compreender se o que é ficção seria na verdade parte do real, pois a verdade desta obra está na maneira como se conta e para quem se conta. Seu completo entendimento e o dimensionamento que dela se dá dependem do repertório de quem a contempla.

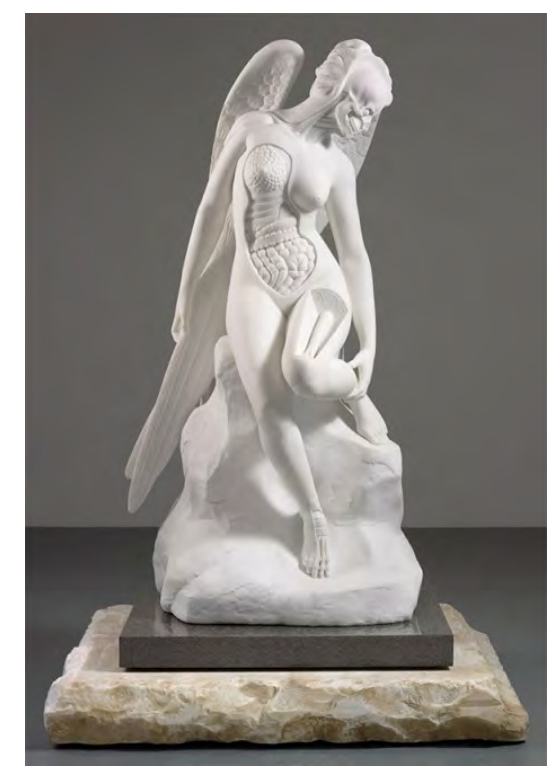

Figura 53: Damien Hirst - Anatomia de um anjo - 2008 - Tate Modern - Londres ${ }^{55}$

\footnotetext{
${ }^{55}$ Disponível em: <http://www.damienhirst.com/the-anatomy-of-an-angel> Acesso em 18/05/2014
} 
Sendo um dos males que afligem a sociedade contemporânea, a depressão também tomou seu lugar junto aos seres humanos. Como nos tempos modernos, o anjo vem sendo retratado cada vez mais à imagem e semelhança dos humanos, com características estéticas físicas como pelos e calvície e não há como deixar de fora também um anjo deprimido. A obra Angel (1997), de Ron Mueck, retrata tal situação, demonstra o ser alado de modo solitário e desamparado. Mueck, nesse caso, possui como proposição artística a capacidade de manipulação do espaço-tempo, visto que para entrar em contato visual com os olhos do anjo é necessário mover-se buscando por ângulos mais convenientes para qualquer tipo de contato visual. Ao consegui-lo, detecta-se sensações de vida vazia e sem sentido que tal obra traduz, tanto que não há por parte do espectador uma intenção de um novo olhar, pois há logo uma desistência, visando o não enfrentamento, visto que preferencialmente busca-se não vivenciar o sofrimento ou amenizá-lo, modificando comportamentos, dispensando problemas alheios aos nossos.

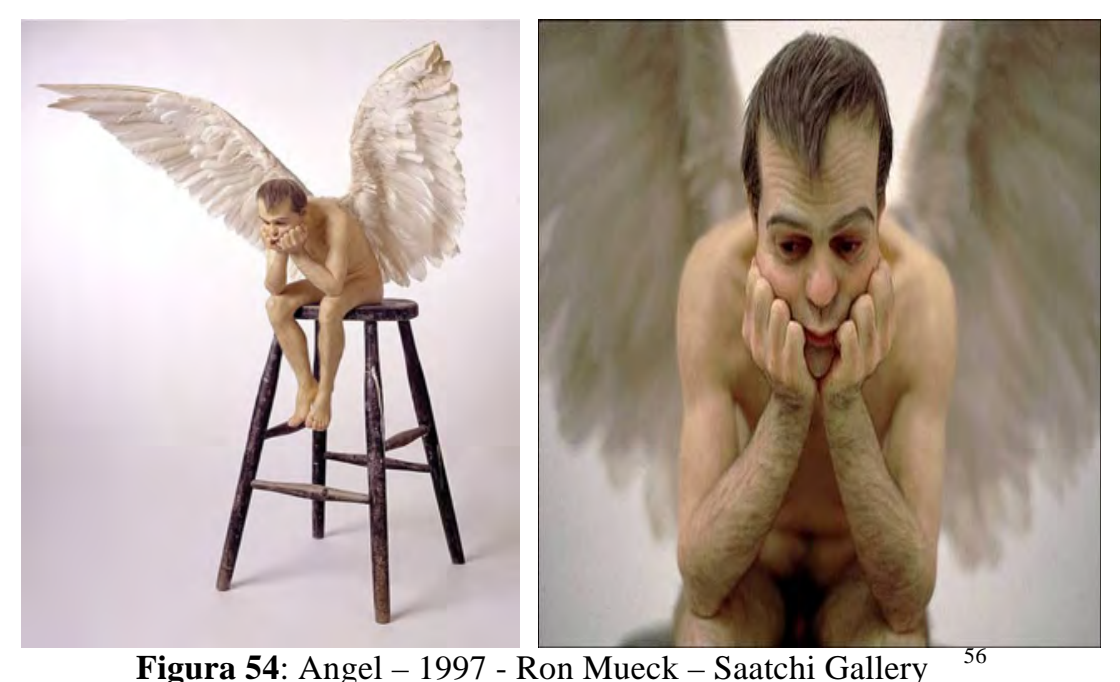

Exemplo de anjo na contemporaneidade completamente adverso aos reproduzidos imageticamente em igrejas e locais sacros, está presente na obra dos artistas chineses Sun Yuan e Peng Yu em Pequim.

Ao criarem um anjo esculpido em um corpo cansado e velho, com asas depenadas, retiram-lhe seu bem mais precioso, a capacidade de voar. Transformando-o em idoso, demonstram sua relação com o que é efêmero não lhe dando disposição para novas e possíveis vivências, fazendo-o reflexo das etapas da vida terrena.

\footnotetext{
${ }^{56}$ Disponível em: <http://www.saatchigallery.com/aipe/ron_mueck.htm> Acesso em 18/05/2014
} 
De corpo frágil, cabelos alvos, pele enrugada e cheia de dobras, esse anjo ao surgir caído diante do espectador como testemunha, esteticamente atesta sua aproximação com a vivência da materialidade e do esgotamento da vitalidade de sua função divinal na terra, ou seja, um anjo com fraquezas diante da vida, assim como o ser humano o pode ser.

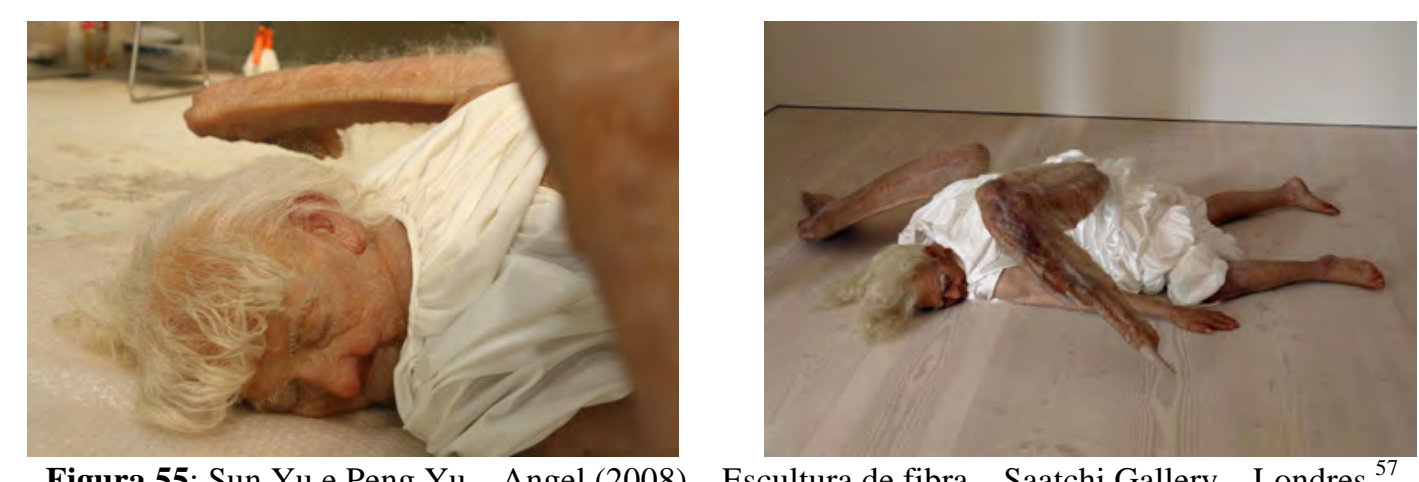

Figura 55: Sun Yu e Peng Yu - Angel (2008) - Escultura de fibra - Saatchi Gallery - Londres ${ }^{57}$

\subsection{O anjo e outras artes}

\subsubsection{Os anjos na Divina Comédia de Dante}

Apesar de um maior destaque e presença nas pinturas e esculturas produzidas com o transcorrer dos séculos, os anjos também foram exaltados e inseridos em outras formas de gêneros artísticos, tais como a literatura, o cinema, o teatro entre outros.

Dante Alighieri, Poeta italiano, foi um dos que produziram poemas épicos repletos de elucubrações sobre hierarquias angelicais.

De extrema relevância literária mundial e uma das mais importantes obras de Dante, A Divina Comédia disserta alegoricamente sobre a existência e o destino da alma humana em forma de peregrinação após a morte. Permitindo diversas perspectivas de leitura que vão desde a visão cristã abordando a remissão dos pecados até a contemplação divina. Ou, ao ser tratado como um poema político, no qual muitos dos inimigos de Dante são citados durante sua jornada, principalmente no inferno, algo que mais tarde lhe custaria o exílio de Florença, o autor permite que tenhamos uma visão que vá além da doutrina católica, visto que

\footnotetext{
${ }^{57}$ Disponível em: < http://www.saatchigallery.com/artists/artpages/yu_yuan_angel_a.htm> Acesso em 18/05/2014
} 
a jornada pelo inferno torna-se uma empreitada psicológica, na qual quanto mais se aprofunda mais difícil fica para enfrentar a realidade da dor, definindo de maneira detalhista a natureza do pecado.

Em uma divisão quase geométrica, Dante Alighieri adotou 100 cantos, sendo 34 destinados a sua jornada ao inferno punidor, 33 ao purgatório e os 33 restantes ao paraíso acompanhado de sua musa Beatriz. Há também por diversas vezes na obra o destaque para o número 3 , visto que é toda escrita em tercetos, a chamada terça-rima ${ }^{58}$, além da alusão à Santíssima Trindade, entre outras citações no decorrer dos manuscritos.

No esquema de Dante, o inferno, corresponde à visão medieval do mundo e é inserido por ele no interior da terra representando-o como um local de isolamento eterno das almas. Naqueles tempos, a Bíblia, apesar de sua autoridade sobre os homens, possuía termos vagos e míticos e Dante conseguiu através de sua obra dar ao inferno forma, estrutura e tamanho, com detalhes precisos e particularidades.

Com nove círculos concêntricos, formando um funil invertido, terminando no centro da terra, o inferno na visão de Dante teria sido formado quando Lúcifer, o anjo caído, que por ser invejoso e querer se comparar a Deus, foi expulso do céu. Em sua queda, o atrito de sua massa corpórea deslocou para baixo tudo o que estava à sua frente. De estruturas bem definidas, cada círculo do inferno representa um tipo e uma classe distinta de pecadores com um tormento particular e à medida que se desce de nível, a gravidade destas más ações fica ainda mais latente na jornada.

O centro do inferno descrito na obra é distinto do que é conhecido por muitos em nossa contemporaneidade. Ao chegar ao último círculo, o nono (o abismo gelado de Lúcifer) acompanhado de Virgílio, Dante encontra frio e gelo. Ali, Lúcifer está aprisionado da cintura para cima e o anjo caído é apresentado alegoricamente como uma figura de três cabeças, que vencido pela mágoa, verte lágrimas e bate incessantemente suas asas, impotente, ignorante e cheio de ódio.

Na Idade Média, a esperança era algo ressurgente, visto que naquela época a vida era breve devido ao surgimento de doenças devastadoras, ao poder da Inquisição e à violência política. Para muitos, a vida eterna era o que deu a Dante tal perspectiva para escrever a Divina Comédia onde o principal objetivo era demonstrar que a vida após a morte e como as

\footnotetext{
58 Terça-rima: tipo de poema estrófico constituído por uma série de tercetos onde: o $1^{\circ}$ e o $3^{\circ}$ versos rimam entre si, a rima do $2^{\circ}$ verso fará par com o $1^{\circ}$ e o $3^{\circ}$ versos da estrofe seguinte, no último terceto é acrescentada uma linha cuja rima se faz com o $2^{\circ}$ verso da mesma estrofe.
} 
escolhas de um indivíduo poderiam influenciar nesta passagem. Para isso, Dante utilizou em sua obra, personagens baseados em figuras do seu tempo e de fatos que existiram.

Na visão de Dante, o purgatório, local de purificação expiatória, era composto por sete platôs circulares, que se elevavam sucessivamente à medida que se aproximavam do topo. Cada uma destas coroas correspondia a um dos sete pecados capitais.

Já o paraíso, construído a partir de um sistema cosmográfico, consistia em nove céus concêntricos com a terra, onde cada céu possuía uma ordem angelical distinta que o presidia e exercia influência sobre os humanos e seus assuntos, tudo isso conforme ilustrados nas figuras que seguem: 


\section{Cielo y Purgatorio Dantescos}

Estos pasajes también fueron desarrollados por la imaginación del poeta, igualmente complejos y de gran influencia en nuestra época.
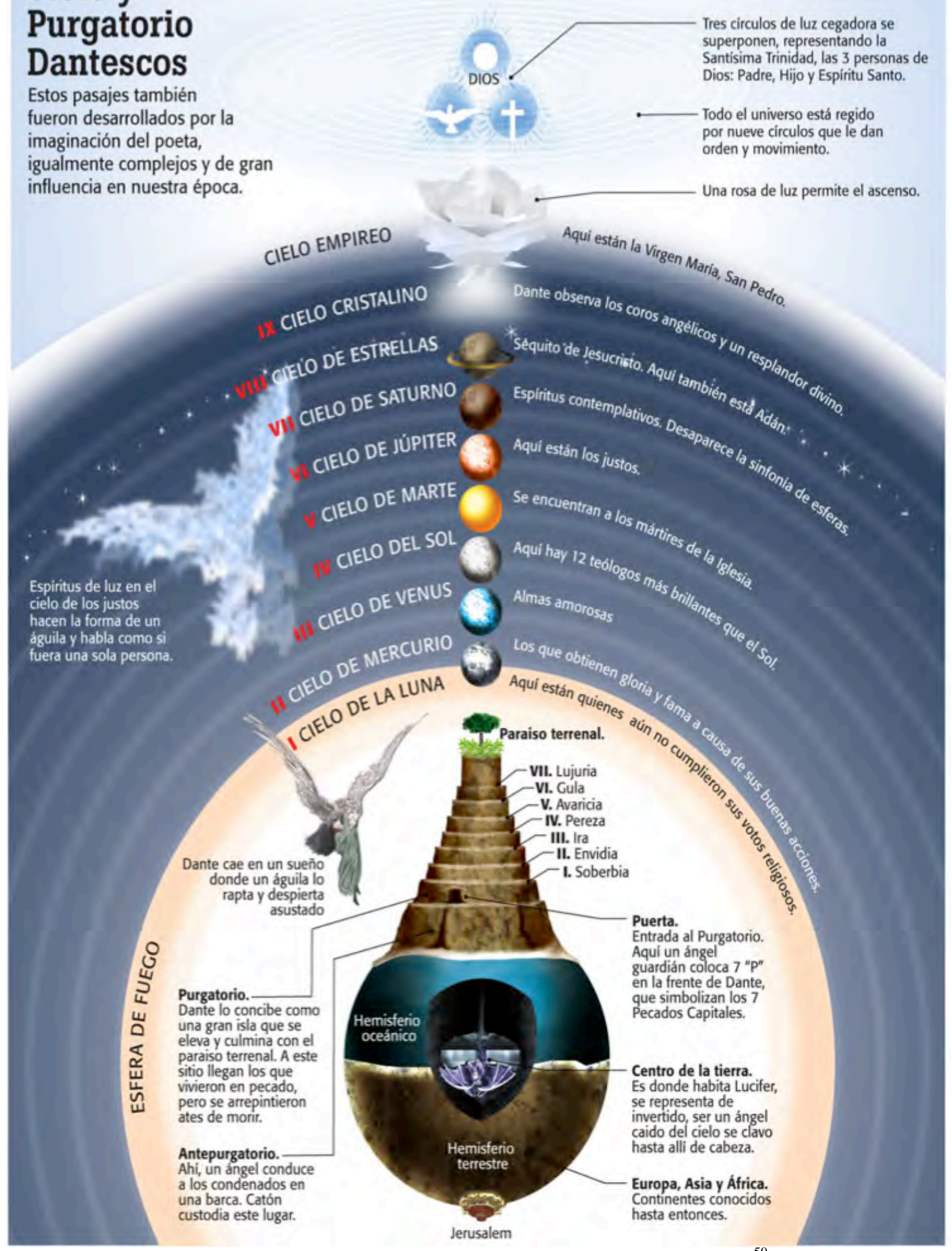

Figura 56: Céu e purgatório na Divina Comédia de Dante Alighieri ${ }^{59}$

${ }^{59}$ Disponível em: <http://3.bp.blogspot.com/-oPjWHQP2vwA/UHNd5gyOh1I/AAAAAAAAAYI/T-QTfuml1o/s1600/CIELOPURGATORIOcopy.jpg> Acesso em 18/10/14 


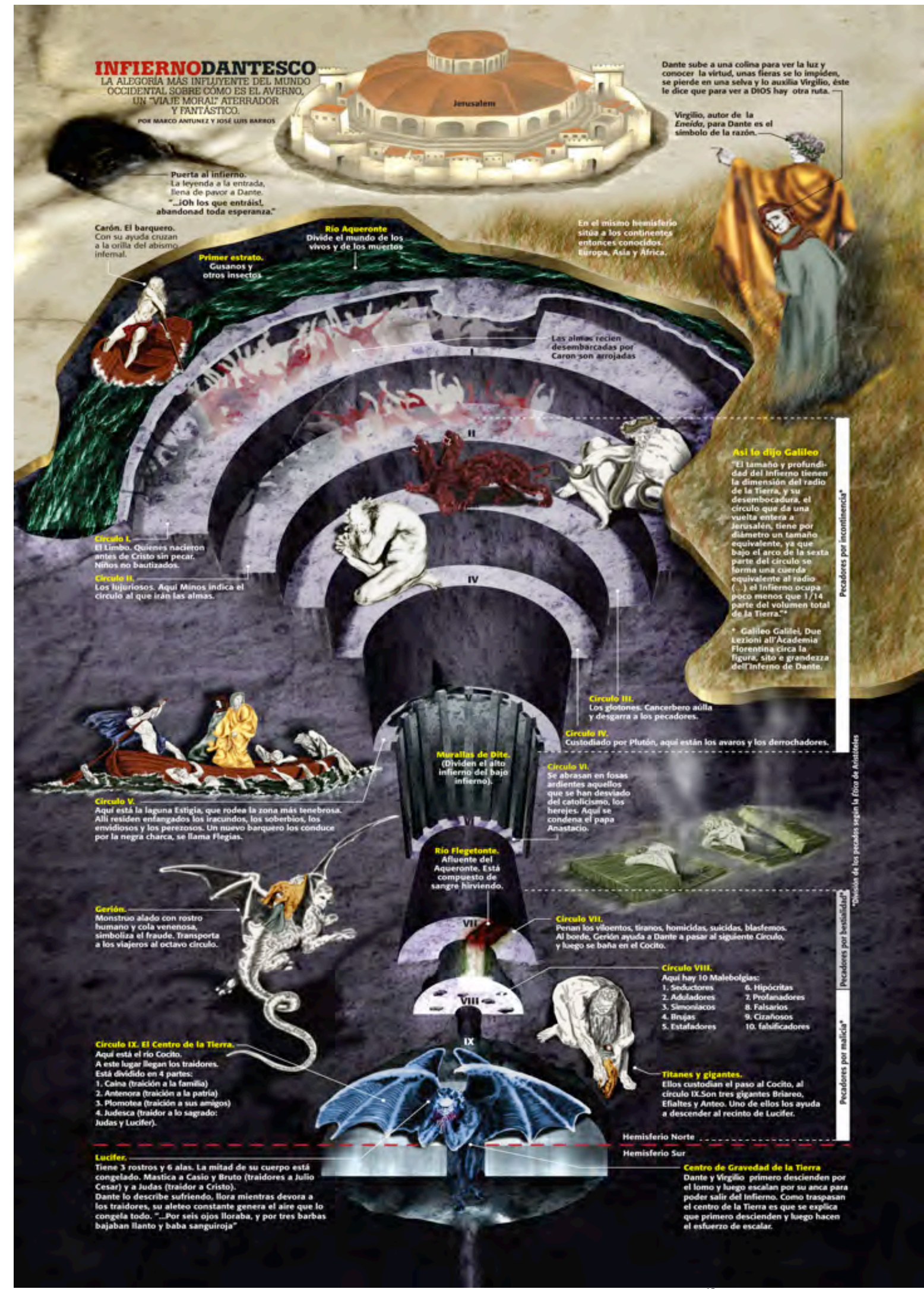

Figura 57: Inferno na Divina Comédia de Dante Alighieri60

${ }^{60}$ Disponível em: <https://alfredovela.files.wordpress.com/2013/11/infografia_el_infierno_segun_dante.jpg> Acesso em 18/10/14 


\subsubsection{Os anjos e a sétima arte}

Os anjos, por serem personagens advindos do imaginário embasado na literatura bíblica e devido à natureza fantástica e etérea que possuem, têm frequentemente feito parte de várias películas, sendo na maioria das vezes os protagonistas ou então coadjuvantes de suma relevância para os roteiros fílmicos. Apesar das produções hollywoodianas serem predominantes, muitas são as nacionalidades que abordam estes personagens celestiais, não havendo uma especificidade, indo de criações alemãs como é o caso do aclamado "Asas do Desejo" até "Barbarella" produção franco-italiana.

O cinema, ao permitir o caráter ficcional e subjetivo, dá aos produtores e diretores da película a ser concebida a oportunidade de interpretar e retratar imageticamente o céu e a aparência de seus habitantes conforme lhes convém ou como acreditam que tais personagens possam causar algum tipo de identificação com o espectador, já que:

\footnotetext{
"O vestuário, o rosto, as palavras, o sentimento da nossa importância, tudo isso alimenta, na vida corrente, esse espetáculo que damos nós próprios e aos outros, ou seja, as projeções-identificações imaginárias. Na medida em que identificamos as imagens da tela com a vida real, pomos nossas projeções-identificações referentes à vida real em movimento" (MORIN apud LERMEN, 2013, p.51)
}

Durante muito tempo, a interpretação mais comum do céu era aquela até hoje arraigada na crença popular, em que o paraíso celestial é dotado de enormes portões dourados, repleto de nuvens e sob o controle de São Pedro e suas chaves. Quando retratados de tal maneira, não incomum é encontrarmos estes anjos paramentados com longas batas brancas, tocando harpas e portadores de asas e auréolas.

Entretanto, quando representados artisticamente nas películas cinematográficas, os anjos são orientados a deixarem o reino celestial para cumprir suas principais funções: a de mensageiros ou guardiões e quando o fazem, geralmente assumem a forma humana para que possam ser facilmente reconhecíveis e identificáveis por aqueles que visam proteger ou orientar.

Muitos são os filmes já produzidos sobre o tema do anjo e ainda mais variado o seu teor. Notamos em um primeiro momento que, apesar da Bíblia relatar a existência de milhares de anjos, ainda assim destacam-se também nas películas os nomes de: Gabriel, 
Miguel e Rafael. Lúcifer, o anjo caído, também surge em diversas produções, tais como “Anjos Rebeldes" e "Constantine".

Não há aqui a necessidade de interpretação dos inúmeros nomes existentes, bem como se sua origem se deu no islamismo, judaísmo ou outra religião qualquer. Mas é de suma relevância compreender a existência do sufixo "el", extremamente comum nos nomes destes seres angelicais. Em hebraico "el" possui o significado de "alto", "elevado", "acima", porém na língua portuguesa o sufixo em questão é traduzido como "Deus" ou como melhor se encaixaria neste caso, "de Deus".

Notamos também que os anjos quando tomam forma humana ao serem representados pelo cinema, em sua grande maioria, são inseridos nas películas como sendo do sexo masculino, pouquíssimas vezes são representados por mulheres. São mínimas as vezes da androgenia ou o caráter assexuado serem discutidos em filmes. Na grande parte, ou tais características não são abordadas ou o fato acaba sendo descartado quando no roteiro há qualquer tipo de probabilidade de romance com o sexo oposto.

Os aspectos dos anjos barrocos que comumente apresentam como características os cabelos loiros cacheados e olhos azuis, na sétima arte fato não se aplica com a frequência que percebemos nas artes plásticas, havendo no cinema inúmeras distinções físicas para estes seres que vão desde os cabelos longos e escuros até anjos de pele negra.

As asas, que são o elemento mais simbólico do mito do anjo, pois são elas capazes de permitir distingui-los de um ser humano comum e representarem a alma em elevação, nas películas hollywoodianas e europeias, surgem pouquíssimas vezes como adornos fixos destes personagens bíblicos. Em boa parte do enredo, os anjos aparecem paramentados como homens e mulheres normais, somente demonstrando suas asas quando há a iminência de voar, quando ascendem ao céu ou necessitam sobrevoar locais para cumprir sua função de mensageiro.

Quanto ao figurino adotado pelos anjos nos filmes, não há um consenso em relação às vestimentas utilizadas nas filmagens, porém são predominantes alguns estilos tais como os anjos despojados que utilizam macacão jeans com suspensório; os anjos clássicos com túnicas alvas; os anjos sofisticados com terno, gravata e por vezes chapéu; os anjos guerreiros com largos cintos para fixar armas e o uso de coturnos e espartilhos; e finalmente os de anjos vestindo sobretudo, peça de vestuário bastante constante, que se explica em função da necessidade dos anjos precisarem esconder de forma adequada suas asas. 
A tabela a seguir possui como objetivo unir todos os aspectos acima listados incluindo ainda a personalidade e função dos anjos nos principais filmes já exibidos sobre o tema até hoje. Nela é possível identificar o título do filme, seu ano de exibição, diretor responsável, gênero, anjos que protagonizaram a película e forma com que foram apresentados visualmente, se há ou não menção da genealogia a que pertencem, a hierarquia da qual fazem parte, bem como sua função no filme para que seja possível a percepção da diversidade apresentada em todos os aspectos conforme o já descrito. 
TABELA 3 - ELEMENTOS QUALITATIVOS DOS ANJOS NO CINEMA

\begin{tabular}{|c|c|c|c|c|c|c|c|c|c|}
\hline FILME & ANO & DIRETOR & GÊNERO & ANJO/NOME & FORMA & GENEALOGIA & HIERARQUIA & PERSONALIDADE & MINISTÉRIO/FUNÇĀO \\
\hline $\begin{array}{c}\text { ANJOS } \\
\text { REBELDES }\end{array}$ & 1995 & $\begin{array}{l}\text { Gregory } \\
\text { Widen }\end{array}$ & $\begin{array}{l}\text { Terror / } \\
\text { Fantasia }\end{array}$ & $\begin{array}{c}\text { Gabriel, Uziel } \\
\text { e Lúcifer }\end{array}$ & $\begin{array}{c}\text { Homens. Uziel e Lucifer, cerca } \\
\text { de } 35 \text { anos, cabelos (até os } \\
\text { ombros) e olhos claros, } \\
\text { trajando sobretudo. Gabriel é } \\
\text { mais velho (cerca de } 50 \text { anos), } \\
\text { cabelos escuros curtos e olhos } \\
\text { claros. }\end{array}$ & \begin{tabular}{|c|} 
Fazem \\
menção a já \\
estarem \\
presentes na \\
terra antes \\
da criação do \\
homem.
\end{tabular} & Arcanjos & $\begin{array}{c}\text { Gabriel: rebelde, } \\
\text { maquiavélico, frio e } \\
\text { ameaçador. Uziel: } \\
\text { generoso, frágil e } \\
\text { corajoso. Lúcifer: } \\
\text { astuto, articulador } \\
\text { e asqueroso. }\end{array}$ & $\begin{array}{c}\text { Gabriel: busca criar um } \\
\text { novo inferno com anjos } \\
\text { rebelados a partir da alma } \\
\text { de um coronel } \\
\text { manifestada em uma } \\
\text { criança. Uziel: anjo bom } \\
\text { enviado para derrotar } \\
\text { Gabriel, mas perde suas } \\
\text { forças e morre. Lúcifer: } \\
\text { atua como um segundo } \\
\text { vilão porém auxilia o } \\
\text { "bem" pelo interesse } \\
\text { pessoal de não querer um } \\
\text { segundo inferno como } \\
\text { concorrência de Gabriel. }\end{array}$ \\
\hline $\begin{array}{l}\text { MICHAEL: UM } \\
\text { ANJO } \\
\text { SEDUTOR }\end{array}$ & 1996 & $\begin{array}{l}\text { Nora } \\
\text { Ephron }\end{array}$ & $\begin{array}{l}\text { Comédia / } \\
\text { Romance }\end{array}$ & Michael & $\begin{array}{l}\text { Homem com asas e cabelos } \\
\text { escuros até os ombros. } \\
\text { Levemente acima do peso, } \\
\text { olhos claros. }\end{array}$ & $\begin{array}{c}\text { Menciona-se } \\
\text { apenas que } \\
\text { "caiu do céu" }\end{array}$ & $\begin{array}{c}\text { Não } \\
\text { mencionada }\end{array}$ & $\begin{array}{c}\text { Atrapalhado, } \\
\text { acomodado, } \\
\text { ingênuo, resignado, } \\
\text { sedutor, prestativo, } \\
\text { protetor. }\end{array}$ & $\begin{array}{c}\text { Regenerar-se como anjo } \\
\text { em suas funçz̃es de cura, } \\
\text { proteção, etc e ao mesmo } \\
\text { tempo proteger pessoas e } \\
\text { auxiliar a união de um } \\
\text { casal apaixonado, mas } \\
\text { confuso, como uma } \\
\text { espécie de cupido. }\end{array}$ \\
\hline $\begin{array}{l}\text { POR UMA } \\
\text { VIDA MENOS } \\
\text { ORDINÁRIA }\end{array}$ & 1997 & $\begin{array}{l}\text { Danny } \\
\text { Boyle }\end{array}$ & Comédia & $\begin{array}{c}\text { Gabriel, } \\
\text { O'Reilly e } \\
\text { Jackson }\end{array}$ & $\begin{array}{c}\text { Dois homens. Gabriel, homem } \\
\text { de meia idade, perfil executivo } \\
\text { (veste ternos brancos); } \\
\text { O'Reilly, homem negro de } \\
\text { meia idade. Jackson, mulher, } \\
\text { média de } 40 \text { anos, loira. } \\
\text { O'Reilly e Jackson usam } \\
\text { roupas acinzentadas } \\
\text { normalmente com sobretudo. }\end{array}$ & $\begin{array}{l}\text { Não } \\
\text { mencionada }\end{array}$ & $\begin{array}{c}\text { Não } \\
\text { mencionada }\end{array}$ & $\begin{array}{c}\text { Gabriel: estressado, } \\
\text { submisso e } \\
\text { bondoso. O'Reilly: } \\
\text { calmo, analítico e } \\
\text { passivo. Jackson: } \\
\text { desesperada, } \\
\text { ansiosa, prática e } \\
\text { dissimulada }\end{array}$ & $\begin{array}{c}\text { Ambos tema função de } \\
\text { unir um casal totalmente } \\
\text { incompativel, provando } \\
\text { que o amor é possivel } \\
\text { entre os opostos, para } \\
\text { assim manterem suas } \\
\text { condiçz̃es e privilégios de } \\
\text { anjos no céu. }\end{array}$ \\
\hline $\begin{array}{l}\text { CIDADE DOS } \\
\text { ANJOS }\end{array}$ & 1998 & $\begin{array}{c}\text { Brad } \\
\text { Silberling }\end{array}$ & \begin{tabular}{|c|} 
Romance / \\
Espiritualista
\end{tabular} & Seth e Cassiel & $\begin{array}{c}\text { Seth tem forma humana, } \\
\text { olhos claros, cabelos curtos } \\
\text { escuros, cerca de } 40 \text { anos, } \\
\text { veste roupas escuras, na } \\
\text { maioria das vezes sobretudo. } \\
\text { Cassiel tem a mesma faixa } \\
\text { etária, é negro e usa roupas } \\
\text { iguais as de Seth. }\end{array}$ & \begin{tabular}{|c|} 
Fazem \\
menção a já \\
estarem \\
presentes na \\
terra antes \\
da criação do \\
homem.
\end{tabular} & $\begin{array}{c}\text { Não } \\
\text { mencionada }\end{array}$ & $\begin{array}{c}\text { Calmos, protetores, } \\
\text { inspirados. Seth: } \\
\text { curioso, } \\
\text { observador, } \\
\text { obstinado. }\end{array}$ & $\begin{array}{c}\text { Inspirar os habitantes de } \\
\text { Los Angeles com bons } \\
\text { pensamentos, afastando } \\
\text { tristezas e encaminhando } \\
\text { os recém falecidos para o } \\
\text { céu. Seth apaixona-se por } \\
\text { uma mulher e sua história } \\
\text { passa a ser a renúncia da } \\
\text { condição de anjo para } \\
\text { imersao na condição de } \\
\text { homem, ficando ao lado } \\
\text { da mulher que ama e } \\
\text { habituando-se ao " } \\
\text { mundo' }\end{array}$ \\
\hline $\begin{array}{c}\text { ANJOS } \\
\text { REBELDES } 2\end{array}$ & 1998 & $\begin{array}{l}\text { Greg } \\
\text { Spence }\end{array}$ & $\begin{array}{l}\text { Terror / } \\
\text { Fantasia }\end{array}$ & $\begin{array}{l}\text { Gabriel e } \\
\text { Danyael }\end{array}$ & $\begin{array}{l}\text { Dois homens. Gabriel idem } \\
\text { Anjos Rebeldes } 1 \text { Danyael } \\
\text { possui traços asiáticos e } \\
\text { vestimenta casual. }\end{array}$ & \begin{tabular}{|c|} 
Fazem \\
menção a já \\
estarem \\
presentes na \\
terra antes \\
da criação do \\
homem.
\end{tabular} & $\begin{array}{l}\text { Arcanjos (um } \\
\text { do céu, outro } \\
\text { do inferno) }\end{array}$ & \begin{tabular}{|c|} 
Gabriel: \\
dissimulado, \\
ardiloso, violento e \\
obstinado. Danyael: \\
misterioso, doce, \\
calmo e protetor.
\end{tabular} & $\begin{array}{c}\text { Danyael engravida } \\
\text { Valerine e zela por sua } \\
\text { proteção até que possa } \\
\text { nascer um bebê meio } \\
\text { homem e meio anjo. Uma } \\
\text { nova criatura capaz de } \\
\text { salvar o lado bom da } \\
\text { humanidade. }\end{array}$ \\
\hline DOGMA & 1999 & $\begin{array}{l}\text { Kevin } \\
\text { Smith }\end{array}$ & Comédia & $\begin{array}{c}\text { Bartleby e } \\
\text { Loki }\end{array}$ & $\begin{array}{l}\text { Humana, masculina, jovens. } \\
\text { Trajes esportivos como } \\
\text { camiseta e moletom na forma } \\
\text { humana. Na forma "angelical" } \\
\text { apresentam-se com armadura, } \\
\text { escudo, grandes asas brancas } \\
\text { e a capacidade de voar. Citam } \\
\text { serem assexuados. São } \\
\text { fisicamente parecidos, sendo } \\
\text { Bartleby moreno e Loki loiro. }\end{array}$ & $\begin{array}{c}\text { Mencionara } \\
\text { m como } \\
\text { existentes } \\
\text { desde a } \\
\text { criação do } \\
\text { mundo como } \\
\text { criaturas } \\
\text { feitas por } \\
\text { Deus. }\end{array}$ & $\begin{array}{c}\text { Năo } \\
\text { mencionada }\end{array}$ & $\begin{array}{l}\text { Sábios, cômicos, } \\
\text { bem humorados } \\
\text { obstinados e } \\
\text { insensatos }\end{array}$ & $\begin{array}{l}\text { Bartleby e Loki são anjos } \\
\text { expulsos do céu e que } \\
\text { querem retomar. A única } \\
\text { alternativa é cruzar o } \\
\text { portal de uma igreja em } \\
\text { Nova Jersey para, sendo } \\
\text { assim absolvidos de seus } \\
\text { pecados, retornando ao } \\
\text { paraiso. }\end{array}$ \\
\hline & & & & & & & & & \\
\hline
\end{tabular}




\begin{tabular}{|c|c|c|c|c|c|c|c|c|c|}
\hline FILME & ANO & DIRETOR & GENERO & ANJO/NOME & FORMA & GENEALOGIA & HIERARQUIA & PERSONALIDADE & MINISTÉRIO/FUNÇĀO \\
\hline $\begin{array}{c}\text { ANJOS } \\
\text { REBELDES 3: } \\
\text { ASCENDENTE }\end{array}$ & 2000 & $\begin{array}{l}\text { Patrick } \\
\text { Lussier }\end{array}$ & $\begin{array}{c}\text { Fantasia / } \\
\text { Mistério / } \\
\text { Terror }\end{array}$ & $\begin{array}{c}\text { Gabriel, } \\
\text { Daniel e } \\
\text { Zofael }\end{array}$ & $\begin{array}{l}3 \text { homens: Daniel - jovem, } \\
\text { figurino social, cabelos } \\
\text { escuros, levemente longos. } \\
\text { Zofael - asiático, cabelos } \\
\text { escuros levemente longos, } \\
\text { figurino clássico na maioria } \\
\text { das vezes colete. Gabriel - } \\
\text { cabelos compridos, claros, } \\
\text { desgrenhados, usa sobretudo, } \\
\text { luvas e tem uma aparência de } \\
\text { andarilho. }\end{array}$ & \begin{tabular}{|c|} 
Idem Anjos \\
Rebeldes $1 \mathrm{e}$ \\
2 \\
\end{tabular} & Arcanjos & $\begin{array}{c}\text { Gabriel: protetor, } \\
\text { bem humorado, } \\
\text { sábio. Daniel: } \\
\text { protetor, justiceiro, } \\
\text { forte, obstinado, } \\
\text { ingênuo. Zofael: } \\
\text { cruel, fiel, ardiloso, } \\
\text { sedutor. Pyriel: } \\
\text { sanguinário, } \\
\text { assassino, } \\
\text { impiedoso, } \\
\text { obstinado. }\end{array}$ & $\begin{array}{l}\text { Daniel tem como função } \\
\text { salvar o mundo do } \\
\text { genocídio objetivado por } \\
\text { Pyriel. Gabriel tem a } \\
\text { funçăo de proteger } \\
\text { Daniel. Zofael tem como } \\
\text { função auxiliar sey senhor } \\
\text { Pyriel a executar sua } \\
\text { tarefa de ganhar muitas } \\
\text { almas para o inferno. } \\
\text { Pyriel é o promotor da } \\
\text { guerra entre o céu e } \\
\text { inferno que busca destruir } \\
\text { a humanidade. }\end{array}$ \\
\hline $\begin{array}{l}\text { SEM NOTÍCIAS } \\
\text { DE DEUS }\end{array}$ & 2001 & $\begin{array}{c}\text { Agustín } \\
\text { Díaz Yanes }\end{array}$ & $\begin{array}{l}\text { Comédia / } \\
\text { Fantasia }\end{array}$ & $\begin{array}{l}\text { Lola e } \\
\text { Carmem }\end{array}$ & $\begin{array}{c}\text { Mulheres, entre } 30 \text { e } 40 \text { anos. } \\
\text { Lola é loira com traços mais } \\
\text { clássicos e delicados, traja } \\
\text { roupas discretas. Carmem é } \\
\text { morena e com traços mais } \\
\text { exóticos e sensuais, traja } \\
\text { roupas provocantes e por } \\
\text { vezes é completamente } \\
\text { masculina em seu andar e } \\
\text { vestir. }\end{array}$ & $\begin{array}{l}\text { Ex-humano } \\
\text { que após a } \\
\text { morte virou } \\
\text { anjo }\end{array}$ & $\begin{array}{c}\text { Anjos servem a } \\
\text { lideres maiores } \\
\text { (ex. outros } \\
\text { anjos e } \\
\text { Lúcifer0, sem } \\
\text { nominar em } \\
\text { especíico a } \\
\text { hierarquia. }\end{array}$ & $\begin{array}{l}\text { Lola: compassiva, } \\
\text { delicada, dedicada } \\
\text { e ponderada. } \\
\text { Carmem: ousada, } \\
\text { intolerante, } \\
\text { sensual, atrevida e } \\
\text { revoltada. }\end{array}$ & $\begin{array}{c}\text { Lola (para o céu) e } \\
\text { Carmem (para o inferno) } \\
\text { tem a missão de conseguir } \\
\text { a alma de Manny, um } \\
\text { boxeador em fim de } \\
\text { carreira a fim de que o } \\
\text { céu ou o inferno seja } \\
\text { declarado "vencedor". }\end{array}$ \\
\hline $\begin{array}{l}\text { O CÉU PODE } \\
\text { ESPERAR }\end{array}$ & 2001 & $\begin{array}{c}\text { Chris } \\
\text { Weitz / } \\
\text { Paul Weitz }\end{array}$ & Comédia & King e Keyes & $\begin{array}{l}2 \text { homens, cerca de } 40 \text { anos, } \\
\text { vestem-se com ternos azuis- } \\
\text { celestes. King é mais sóbrio. } \\
\text { Keyes possui estampas que } \\
\text { simulam o seu terno e usa } \\
\text { óculos (aspecto nerd) Ambos } \\
\text { possuem cabelos curtos e } \\
\text { escuros. }\end{array}$ & $\begin{array}{c}\text { Não } \\
\text { mencionada }\end{array}$ & $\begin{array}{l}\text { King é "chefe } \\
\text { do céu" e } \\
\text { Keyes seu } \\
\text { assistente. }\end{array}$ & $\begin{array}{c}\text { Keyes: atrapalhado, } \\
\text { ansioso, infantil e } \\
\text { engraçado. King: } \\
\text { bem humorado, } \\
\text { maduro, confiante } \\
\text { e rigido. }\end{array}$ & $\begin{array}{l}\text { King é o "administrador" } \\
\text { do céu e da "rotina" de } \\
\text { chegada das almas no } \\
\text { paraíso. Keyes é um de } \\
\text { seus assessores, contato } \\
\text { direto com os recém } \\
\text { "mortos" chegados ao } \\
\text { céu. Ambos deixam seus } \\
\text { postos para dedicarem-se } \\
\text { exclusivamente à missão } \\
\text { de corrigir o erro de ter } \\
\text { enviado precocemente } \\
\text { Laurence para o paraiso. }\end{array}$ \\
\hline $\begin{array}{c}\text { ANJOS } \\
\text { REBELDES 4: A } \\
\text { GUARDIÃ DO } \\
\text { DESTINO }\end{array}$ & 2005 & $\begin{array}{c}\text { Joel } \\
\text { Soisson }\end{array}$ & Terror & $\begin{array}{l}\text { Belial e } \\
\text { Lúcifer }\end{array}$ & $\begin{array}{c}2 \text { homens. Belial: senhor } \\
\text { idoso, calvo e franzino. Traja } \\
\text { roupas sociais e um sobretudo } \\
\text { semelhante a um detetive. } \\
\text { Lúcifer é jovem, de boa } \\
\text { aparência, olhos negros e em } \\
\text { alguns momentos sem } \\
\text { pupilas. Traja roupas pretas e } \\
\text { largas. }\end{array}$ & \begin{tabular}{|c|} 
Idem Anjos \\
Rebeldes 1,2 \\
e 3 \\
\end{tabular} & $\begin{array}{c}\text { Belial é um } \\
\text { querubim } \\
\text { caído, } \\
\text { assistente de } \\
\text { Lúcifer, arcanjo } \\
\text { do inferno. }\end{array}$ & \begin{tabular}{|} 
Belial: revoltado, \\
obstinado, \\
intrépido, ousado e \\
irônico. Lúcifer: \\
protetor, \\
inteligente e \\
misterioso.
\end{tabular} & $\begin{array}{l}\text { Belial tem como missão } \\
\text { encontrar o livro "Léxico" } \\
\text { que conta com o capitulo } \\
23 \text { da Bíblia relatando a } \\
\text { guerra entre os anjos. } \\
\text { Belial, leal e Lúcifer } \\
\text { buscam obter alguma } \\
\text { vantagem com a guerra } \\
\text { dos anjos, buscando } \\
\text { promover um inferno } \\
\text { agressivo. Satanás ajuda } \\
\text { os seres humanos a lutar } \\
\text { contra Belial, por não } \\
\text { querer concorrência em } \\
\text { seu inferno. }\end{array}$ \\
\hline $\begin{array}{c}\text { ANJOS } \\
\text { REBELDES 5: } \\
\text { RENEGADOS }\end{array}$ & 2005 & $\begin{array}{l}\text { Joel } \\
\text { Soisson }\end{array}$ & $\begin{array}{c}\text { Suspense / } \\
\text { Horror / } \\
\text { Fantasia }\end{array}$ & $\begin{array}{l}\text { Lúcifer e } \\
\text { Stark }\end{array}$ & $\begin{array}{l}\text { Lúcifer é jovem, de boa } \\
\text { aparência, olhos negros e em } \\
\text { alguns momentos sem } \\
\text { pupilas.Traja roupas pretas e } \\
\text { largas. Stark é alto, negro, } \\
\text { forte, usa tatuagens e traja } \\
\text { roupas pretas. }\end{array}$ & $\begin{array}{c}\text { Idem Anjos } \\
\text { Rebeldes } 1 \mathrm{a} \\
4\end{array}$ & $\begin{array}{l}\text { Lúcifer e Stark } \\
\text { são arcanjos. } \\
\text { Alysson é uma } \\
\text { Nephlin (meio } \\
\text { homem e meio } \\
\text { anjo). }\end{array}$ & $\begin{array}{l}\text { Idem Anjos } \\
\text { Rebeldes } 4\end{array}$ & $\begin{array}{c}\text { Lúcifer permanece com a } \\
\text { missão de auxiliar Alysson } \\
\text { (anjos rebeldes 4); Stark é } \\
\text { o responsável em trazer a } \\
\text { verdade para Alysson } \\
\text { (fato de ser nephlin criada } \\
\text { apenas como ferramenta } \\
\text { para proteger o livro } \\
\text { "Léxico"). }\end{array}$ \\
\hline ANGEL-A & 2005 & Luc Besson & $\begin{array}{l}\text { Comédia / } \\
\text { Romance }\end{array}$ & Angela & $\begin{array}{c}\text { Angela é extremamente alta. } \\
\text { Magra, loira de cabelos curtos } \\
\text { e usa vestidp em cor escura, } \\
\text { bastante curto e saltos altos. } \\
\text { Tem aparência de modelo, } \\
\text { mas devido aos trajes é } \\
\text { semelhante a uma prostituta. } \\
\text { Em cena final, mostra } \\
\text { imponentes asas brancas }\end{array}$ & \begin{tabular}{|c|} 
Não é \\
mencionada, \\
porém \\
Angela \\
menciona ela \\
mesma não \\
saber de seu \\
passado e \\
quando/com \\
o foi \\
concebida \\
como anjo.
\end{tabular} & $\begin{array}{c}\text { Não } \\
\text { mencionada }\end{array}$ & $\begin{array}{c}\text { Misteriosa, sensual, } \\
\text { destemida, ousada, } \\
\text { otimista, } \\
\text { consoladora, } \\
\text { complexa e } \\
\text { temerosa. }\end{array}$ & $\begin{array}{l}\text { Angela foi enviada pelo } \\
\text { céu para auxiliar Andre, } \\
\text { uma espécie de golpista } \\
\text { bondoso a não ser } \\
\text { assassinado por agiotas e } \\
\text { demais bandidos com os } \\
\text { quais mantinha negócios, } \\
\text { além de fazê-lo perceber } \\
\text { o quanto pode ser uma } \\
\text { pessoa boa se resgatar a } \\
\text { bondade que habita em } \\
\text { seu coração e transborda } \\
\text { em seus olhos. }\end{array}$ \\
\hline
\end{tabular}




\begin{tabular}{|c|c|c|c|c|c|c|c|c|c|}
\hline FILME & ANO & DIRETOR & GÉNERO & ANJO/NOME & FORMA & GENEALOGIA & HIERARQUIA & PERSONALIDADE & MINISTÉRIO/FUNÇÃO \\
\hline CONSTANTINE & 2005 & $\begin{array}{c}\text { Francis } \\
\text { Lawrence }\end{array}$ & Suspense & Gabriel & $\begin{array}{l}\text { Gabriel é andrógeno, } \\
\text { assexuado. Possui cabelos } \\
\text { loiros e cacheados, parte } \\
\text { longos e parte curtos. Pele } \\
\text { extremamente alva e corpo } \\
\text { frágil. Suas roupas são sempre } \\
\text { claras, com sobreposição de } \\
\text { panos, tiras, etc. Possui asas } \\
\text { que aparecem em alguns } \\
\text { momentos do filme, asas } \\
\text { escuras. de cor cinza. Lúcifer } \\
\text { traja sempre branco, em } \\
\text { ternos clássicos. Tem olhos } \\
\text { azuis, mas como se estivessem } \\
\text { irritados. Possui muitas } \\
\text { tatuagens pretas e com } \\
\text { formas tribais pontiagudas. }\end{array}$ & $\begin{array}{c}\text { Mencionam } \\
\text { como } \\
\text { existentes } \\
\text { desde a } \\
\text { criação do } \\
\text { mundo, } \\
\text { como } \\
\text { criaturas } \\
\text { feitas por } \\
\text { Deus. }\end{array}$ & $\begin{array}{l}\text { Gabriel é um } \\
\text { arcanjo. } \\
\text { Lúcifer, lider do } \\
\text { inferno. }\end{array}$ & $\begin{array}{c}\text { Gabriel: andrógeno, } \\
\text { exótico, } \\
\text { dissimulado e } \\
\text { obstinado. Lúcifer: } \\
\text { asqueroso, irônico } \\
\text { e oportunista. }\end{array}$ & $\begin{array}{l}\text { Lúcifer busca na narrativa } \\
\text { das vida a seu filho } \\
\text { Mammon no campo } \\
\text { humano, através do } \\
\text { ventre de uma mulher } \\
\text { médium. Gabriel, a } \\
\text { princípio é um anjo sábio } \\
\text { e bom, pertencente a } \\
\text { Deus, mas a partir das } \\
\text { promessas de Lúcifer e } \\
\text { somando sua revolta com } \\
\text { os homens, passa a auxiliá- } \\
\text { lo a consguir dar um } \\
\text { nascimento humano a } \\
\text { "Mammon". }\end{array}$ \\
\hline $\begin{array}{l}\text { GABRIEL: A } \\
\text { VINGANÇA DE } \\
\text { UM ANJO }\end{array}$ & 2007 & $\begin{array}{c}\text { Shane } \\
\text { Abbess }\end{array}$ & Ação & $\begin{array}{c}\text { Gabriel, Uriel, } \\
\text { Amitiel, Jade, } \\
\text { Ithuriel, } \\
\text { Raphael, } \\
\text { Michael, } \\
\text { Sammae, } \\
\text { Asmodeus, } \\
\text { Balan, } \\
\text { Ahriman e } \\
\text { Lilith }\end{array}$ & $\begin{array}{c}\text { Os anjos Gabriel, Uriel, } \\
\text { Ithuriel, Raphael e Michael } \\
\text { vestem-se com roupas casuais } \\
\text { mas bastante "surradas", com } \\
\text { exceção de Uriel, o mais } \\
\text { velho, os demais são homens, } \\
\text { jovens, com cerca de } 30 \text { a } 35 \\
\text { anos. Jade/Amitiel é morena, } \\
\text { jovem, cerca de } 25 \text { anos. Nas } \\
\text { primeiras cenas seu figurino é } \\
\text { de prostituta, passando } \\
\text { depois a usar roupas largas e } \\
\text { claras, com alguns babados. } \\
\text { Os anjos caídos (Sammael, } \\
\text { Asmodeus, Balan, Ahriman) } \\
\text { trajam-se com mais acessórios } \\
\text { de guerra e peças típicas } \\
\text { como coturnos e coletes. Lilith } \\
\text { usa figurino que lembra } \\
\text { roupas sensuais, masoquistas. }\end{array}$ & $\begin{array}{l}\text { Há menção } \\
\text { de todos os } \\
\text { anjos bons } \\
\text { criados por } \\
\text { Deus, são } \\
\text { eternos no } \\
\text { universo } \\
\text { antes de seu } \\
\text { início, como } \\
\text { "criaturas de } \\
\text { Deus". Os } \\
\text { anjos maus } \\
\text { teriam } \\
\text { surgido com } \\
\text { a queda de } \\
\text { Lúcifer. }\end{array}$ & $\begin{array}{c}\text { Os anjos de luz } \\
\text { demonstraram } \\
\text { estarem } \\
\text { subservientes a } \\
\text { Gabriel, que é } \\
\text { arcanjo; Já os } \\
\text { anjos das } \\
\text { trevas servem } \\
\text { a Sammel, sem } \\
\text { nominar suas } \\
\text { classes em } \\
\text { especifico. }\end{array}$ & $\begin{array}{c}\text { Anjos de luz / Anjos } \\
\text { caídos }\end{array}$ & Anjos de luz / Anjos caídos \\
\hline LEGIÃO & 2010 & $\begin{array}{l}\text { Scott } \\
\text { Stewart }\end{array}$ & Fantasia & $\begin{array}{c}\text { Miguel e } \\
\text { Gabriel }\end{array}$ & $\begin{array}{l}2 \text { homens. Michael é um } \\
\text { homem forte, com aparência } \\
\text { de soldado de guerra. Possui } \\
\text { cerca de } 35 \text { anos, usa } \\
\text { tatuagens tribais e } \\
\text { vestimentas e equipamentos } \\
\text { militares (arma, granada, } \\
\text { colete e botas) Gabriel possui } \\
\text { aparência de "anjo guerreiro" } \\
\text { com imponentes asas escuras } \\
\text { e armadura reluzente. }\end{array}$ & $\begin{array}{c}\text { Há apenas } \\
\text { menção de } \\
\text { Michael ter } \\
\text { sido um anjo } \\
\text { enviado } \\
\text { diretamente } \\
\text { por Deus. }\end{array}$ & Arcanjos & $\begin{array}{c}\text { Michael: protetor, } \\
\text { forte, obstinado, } \\
\text { altruista e rígido. } \\
\text { Gabriel: sóbrio e } \\
\text { obstinado. }\end{array}$ & $\begin{array}{l}\text { Miguel buscará que o } \\
\text { Apocalipse não ocorra } \\
\text { (vontade de Deus, que } \\
\text { envia Gabriel para a terra } \\
\text { a fim de promovê-lo); } \\
\text { Auxilia um pequeno grupo } \\
\text { de pessoas a menterem- } \\
\text { se vivas, em especial } \\
\text { preservando a gravidez de } \\
\text { uma garçonete no intuito } \\
\text { de que o filho ao nascer } \\
\text { será o futuro da } \\
\text { humanidade. É um anjo } \\
\text { rebelado a favor dos } \\
\text { homens, quen luta para } \\
\text { provar para Deus que a } \\
\text { humanidade merece mais } \\
\text { uma chance. }\end{array}$ \\
\hline
\end{tabular}

Fonte: LERMEN, Ionara Cristine, 2013, págs. 119 a 145

\subsubsection{A polêmica de Angels in America}

Nem sempre os anjos são utilizados na arte de maneira habitual, como sendo apenas mentores, protetores ou mensageiros. Sua função primeira por vezes é colocada à prova quando este personagem mítico é inserido como sendo parte relevante de enredos complexos, questionadores e contemporâneos. 


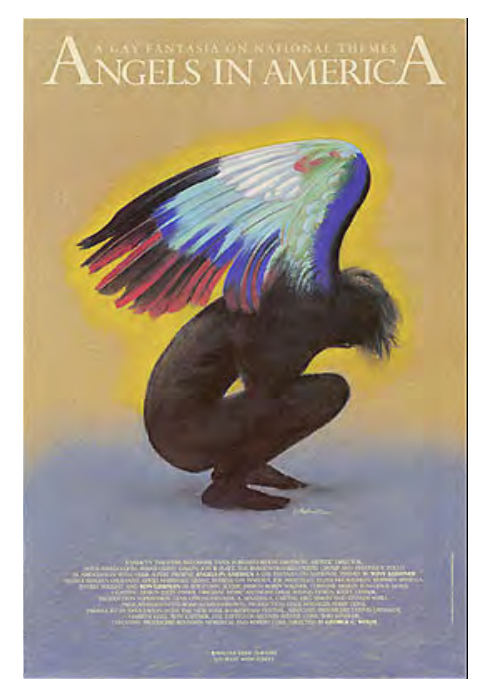

Figura 58: Pôster da peça teatral "Angels in America” 61

É o que podemos dizer da peça teatral "Angels In America: A Gay Fantasia On National Themes" de Tony Kushner, ganhadora do prêmio Pulitzer em 1993 e que posteriormente, foi relançada em 2003 pelo canal HBO, como a minissérie "Angels in America", dirigida por Mike Nichols. Confirmando o sucesso desta produção ao arrebatar 5 Globos de Ouro e 11 Emmy Awards em 2004 teve em seu casting atuações primorosas de grandes astros como Al Pacino, Emma Thompson e Meryl Streep.

O enredo, tanto da peça quanto da minissérie, orbitam sobre a disseminação da Aids, chamada pejorativamente de "peste gay" nos anos 80 e o conservadorismo e descaso do governo Ronald Reagan, nos Estados Unidos. De forma impactante, ao discutir religião, política e sexualidade, "Angels in America" questiona as reações da sociedade e o comportamento humano em relação a temas como a estigmatização e a existência da homossexualidade e as interseções existentes entre todos esses assuntos, através da história de seus personagens.

${ }^{61}$ Disponível em: <http://veja.abril.com.br/blog/temporadas/files/2010/06/cartaz-teatro.jpg> Acesso em 18/06/14 


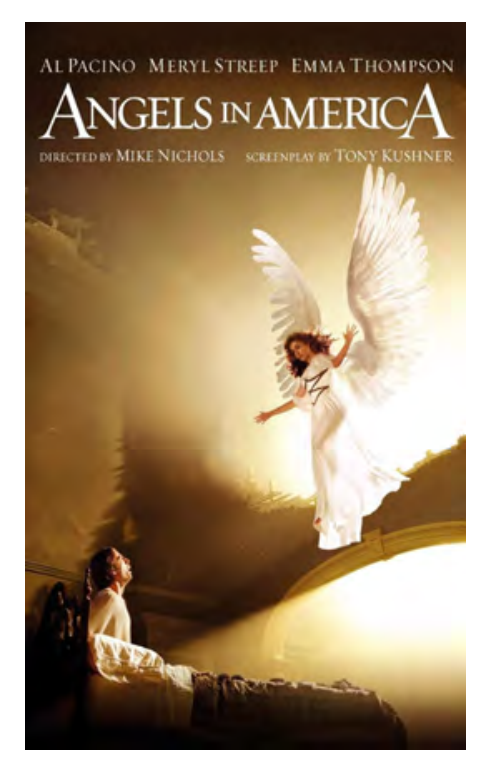

Figura 59: Pôster da minissérie “Angels in America" produzida pelo canal $\mathrm{HBO}^{62}$

Ambientada em uma Manhattan devastada pela epidemia da Aids e local onde pouquíssimas pessoas possuem acesso ao tratamento adequado com o uso do AZT, o simples fato de ser HIV positivo faz com que se travem conflitos dos mais diversos entre os personagens, visto que estar infectado nessa época é o mesmo que admitir a homossexualidade e se ver obrigado a ficar à margem da sociedade.

Abordando dilemas éticos e morais complexos, a peça/série busca demonstrar todas as vítimas desta epidemia - adoentadas ou não - cada qual vivenciando as situações a seu modo, desde um casal homossexual, um deles sem suporte emocional, que abandona o companheiro doente, que acaba por passar por todo tratamento sozinho, até um renomado advogado republicano mórmon e que, por ser gay enrustido, não aceita assumir tal posição, permanecendo na obscuridade para conservar sua posição privilegiada de homem de prestígio e intimidador e quando sua doença progride vê-se em posição vulnerável a tudo aquilo que passou a vida recriminando.

Testando limites, é possível acompanhar especialmente as alucinações de cunho religioso de Prior, um dos personagens que sonha com um anjo, interpretado por Emma Thompson que lhe fala sobre o futuro da humanidade e como tudo está perdido.

Ao final, todos os personagens do enredo teatral buscam por algum tipo de redenção. Uns por trair suas crenças religiosas, outros por terem sido seres humanos deploráveis, outros por terem abandonado pessoas em momento de necessidade extrema. E

62 Disponível em: <http://www.outrapagina.com/blog/wp-content/uploads/2013/08/angelsinamerica.jpg> Acesso em $18 / 06 / 14$ 
mesmo aqueles que não o fazem têm seu destino atrelado aos anjos em busca de um sentido para a vida.

O elemento fantástico e o apelo para o misticismo é o que garante a imprevisibilidade no enredo, visto que se tudo fosse palpável já se saberia o que esperar da peça/série, permitindo que o espectador perceba que o destino dos personagens está nas mãos de forças maiores. A inserção de anjos une a religiosidade e a escolha feita pelos personagens durante sua trajetória no enredo.

$\mathrm{O}$ interessante é que em meio a esta mescla de realidade e fantasia, o autor aproveitou-se de um personagem real da era Reagan. Roy Cohn, na época ligado ao Departamento de Justiça e que foi interpretado por Al Pacino, por ser um homossexual enrustido e HIV positivo, usou de seu tráfico de influência para conseguir provisão do raro medicamento AZT, dando em troca seu silêncio sobre o escândalo Irã-Contras.

Tamanho foi o sucesso da peça "Angels in America" no exterior ao ganhar o Prêmio Pulltzer, que inspirou o diretor musical e professor da Escola de Arte Dramática (EAD) e Escola de Comunicação e Artes (ECA-USP), Iacov Hillel a apostar na montagem brasileira em 1995, porém encontrou resistência e dificuldade na obtenção de patrocínio dado o caráter polêmico da obra.

Se produzir uma peça de teatro já é normalmente difícil no Brasil, as complicaçōes se multiplicam quando temas como Aids e homossexualismo estẫo envolvidos. É o caso de “Angels in America".

Depois de 11 meses de dificuldades, finalmente começa a engrenar a produção brasileira do épico gay norte-americano de Tony Kushner, um dos maiores sucessos teatrais do planeta nos anos 90 . O diretor Iacov Hillel já tem fechados data e local de estréia. “Angels in America - O Milênio se Aproxima", a primeira parte da saga de Kushner, desembarca em São Paulo em 14 de julho, no teatro João Caetano.

A batalha pelo patrocínio continua. Com um rol de cerca de 150 empresas já consultadas, a produção tem até o momento apenas promessas de patrocínio, mas nenhum contrato firmado ainda. Hillel diz que o representante de um banco recusou patrocínio alegando que a empresa não patrocina peças polêmicas.

Ele conta que o diretor de marketing de outra empresa entusiasmou-se com a produção, mas, após uma reunião com a diretoria, voltou com a pergunta: "Você não tem outro projeto?". 
Hillel diz que não descarta a possibilidade de vender seu apartamento para completar o orçamento (de R\$ 220 mil) que os patrocinadores relutam em assumir.

"Não quero me fazer de vítima", diz Hillel. "A dificuldade de patrocínio não é um problema só nosso, é a realidade do teatro brasileiro, que vamos enfrentar."

Após longa busca por um teatro, Hillel conseguiu da Prefeitura o João Caetano, na Vila Mariana, com temporada de três meses.

Depois, a produção terá que procurar novo espaço para concretizar o objetivo de encenar também "Perestroika", a segunda parte da peça, no mesmo espaço, em dias alternados.

A equipe, entusiasmada pelo projeto, procura superar as dificuldades.

"Elas me estimulam, mas tem horas em que você vai chorar num cantinho", diz Vitti.

"Às vezes, chega a dar vontade de parar de fazer teatro", diz o ator

Cássio Scapin. "Mas a peça é importante, discute uma nova conduta social que estamos sendo forçados a assumir".

Figura 60: Crítica no caderno Ilustrada do jornal "Folha de S. Paulo" sobre a montagem brasileira da peça "Angels in America" - Data: 05/05/1995 63

Porém, após conseguir levar a obra adiante, a crítica não foi unânime, apontando cortes no texto que desestruturavam e prejudicaram a montagem brasileira e a perda de qualidade nas atuações dos personagens Ethel Rosemberg e Roy Cohn, porém agraciando a atuação dos atores João Vitti e Cássio Scapin. O anjo aqui surge metaforicamente como mensageiro, restabelecendo o contato com Deus.

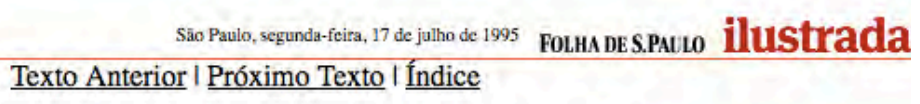

\section{Chega o "Mensageiro" de Tony Kushner}

Cortes no texto e um tom grandiloquente prejudicam a boa montagem brasileira, dirigida por Iacov Hillel

Não foi o desastre anunciado. "Angels in America", versão brasielira, é um espetáculo que mostra bem como as coisas se estabelecem rapidamente, neste fim de milênio.

As palavras dois personagens de Tony Kushner, verdadeiras revelaçōes poucos anos atrás, cristalizam-se e frases inteiras já são encenadas com uma reverência paralisante, com direito a boca de cena, foco de luz e voz empostada.

O museu, tão cedo. Ainda é cedo para falar em Shakespeare; aliás, nem Shakespeare é para ser assim.

Frases como "a história a ponto de arrebentar, o milênio se aproxima ", tiradas do contexto, lançadas como verdades absolutas sobre a platéia, como profecias em algum púlpito, tornam-se vazias e ostentatórias.

Da mesma forma, "chegará o final, o céu desabará e haverá tmpestades horríveis e chuvas de luz venenosa", lançadas do púlpito retoricamente, quase infantilmente, perdem toda a ironia, para não dizer o sentido.

$\mathrm{O}$ americano tony Kushner não é dramaturgo de fazer discurso em cena. Como o alemão Bertold Brecht, sua influência maior, ele é "ambivalente", para ficar na expressão auto-irônica de uma das grandes cenas da peça e uma das cenas mais políticas do teatro contemporâneo, destroçada pelos cortes, na versão brasileira. 
Não se entendem tantos cortes, a não ser pela submissão a uma suposta exigência de tempo do público, exigência já devidamente vencida nas montagens anteriores pelo mundo todo.

Os cortes foram profundos a ponto de virtualmente desaparecer com um dos personagens maiores da peça, Hannah, a mãe mórmon de Joe, advogado republicano gay.

Junto com ela somem duas cenas inteiras, uma com a frase, também de grande auto-ironia, em que uma mendiga louca avisa, "ah, sim, no novo século eu acho que nós seremos todos loucos". Todos serão como ela, a louca pueril que cita Nostradamus e que a versão brasileira simplesmente matou.

Mas talvez a frase e a louca não fossem mesmo grandiloquentes o bastante, para os propósitos grandiloquentes da montagem.

A outra cena cortada, aquela em que Hannah e uma amiga sua, de Salt Lake City, falam com fé dos santos dos últimos dias e como que dão o outro lado, o lado bom dos reacionários mórmons, vem sendo questionada desde as primeiras montagens de "Angels in America". Num debate em Londres, três anos atrás, o dramaturgo defendeu a cena irritado, dizendo que ela estava ali, não simplesmente para sustentar a trama, mas com a função maior de alterar o humor, de mudar o tom da peça, antes do último ato. Mas não adianta, que não entendem e cortam.

Cortes, grandiloquência, mas "Angels in America" sobrevive. E sobrevive em grande parte porque o americano Tony Kushner sabe contar uma história, como ele mesmo gosta de dizer.

No limite, a peça é ela própria sobre o ato de compaixão que é contar uma história, o ato de comunicar.

Depois de um meio século em que o entendimento foi negado, na idéia predominante do teatro, chegando aos casos terminais da última década, com as peças sem palavras, com a rejeição da comunicação como impossível, "Angels in America"surge como um arauto de novos tempos.

No final desta primeira parte de "Angels in America", chamada "O Milênio se Aproxima", a única montada no Brasil (e sem previsão de montagem da segunda parte, menos grandiloquente, chamada "Perestroika"), o anjo desce ao jovem com Aids e anuncia que $o$ Mensageiro chegou.

O anio é o Mensageiro. A metáfora. mais explícita imbossível.é a do restabelecimento da comunicacão com Deus. Acabou a espera por Godot, no trocadilho niilista de Samuel Beckett.

O século que se aproxima é aquele que vai trazer "tolerância, perdão, graça", na profecia "lilás" de Belize, o enfermeiro "drag". O século que se aproxima vai trazer Deus, no bom sentido. Muita gente, a começar do papa João Paulo $2^{\circ}$, passando por Newt Gingrich, já presidenciável dos republicanos, acha a mesma coisa, que " a Grande Obra vai começar". S6́ não concorda com Belize quanto às prioridades. 


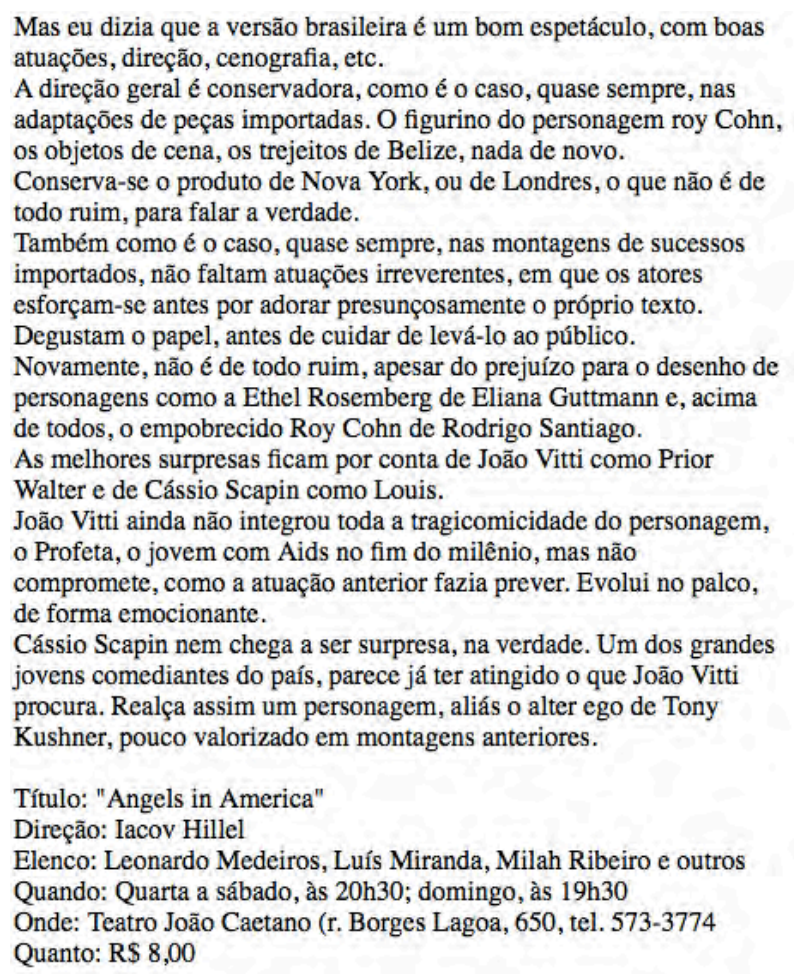

Figura 61: Crítica no caderno Ilustrada do jornal "Folha de S. Paulo" sobre a montagem brasileira da peça "Angels in America" - Data: 17/07/1995 ${ }^{64}$ 


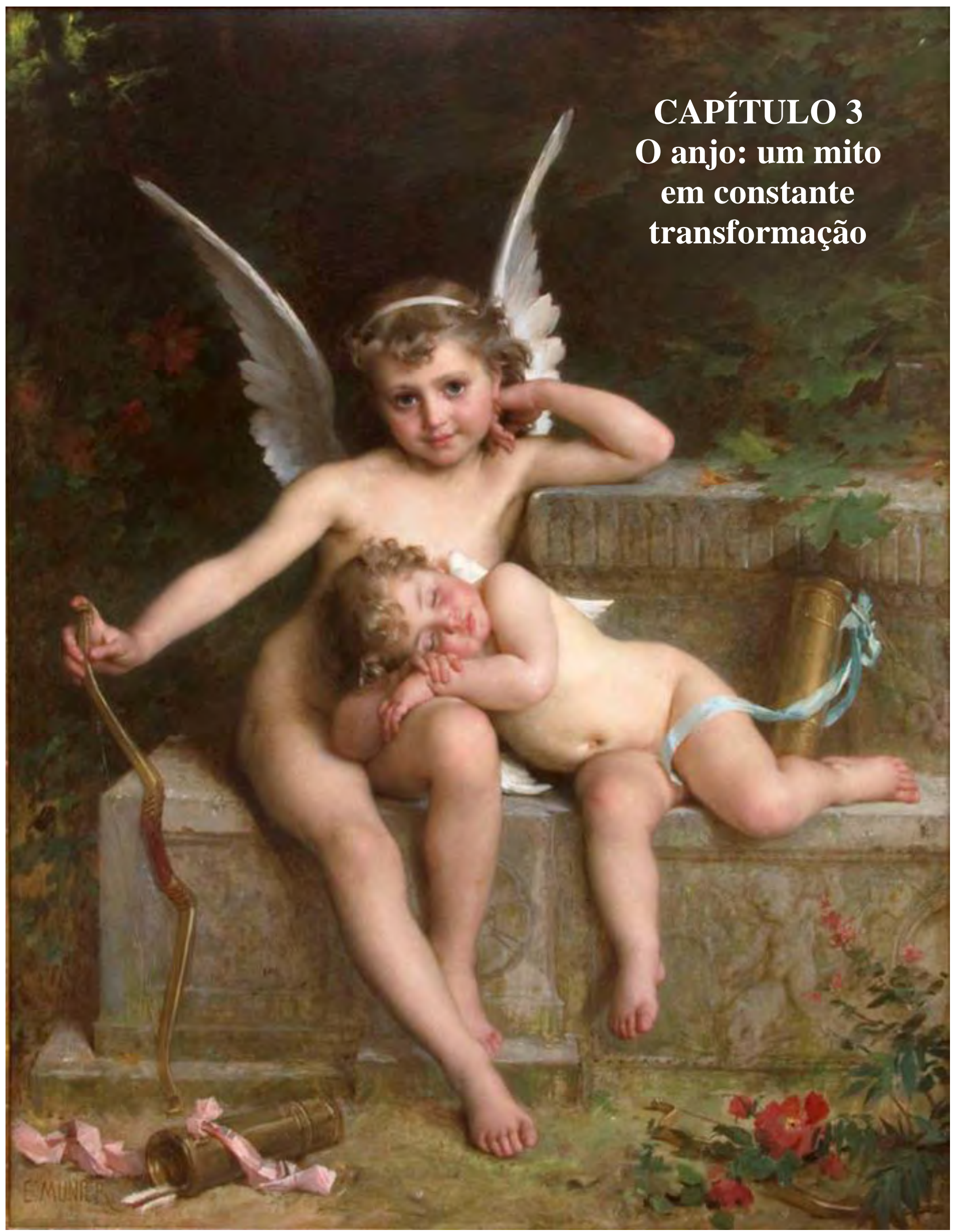




\section{CAPÍTULO 3}

\section{O anjo: um mito em constante transformação}

Há tempos que os anjos exercem fascínio sobre a humanidade e isso se deve a toda a religiosidade e mitologia que cercam tais seres alados. Dotados de asas, por vezes enormes, têm sua imagem ligada à representação das qualidades mais nobres almejadas pelos seres humanos, que acabam sendo utilizadas como atributos para a divulgação de marcas e comercialização de produtos e serviços.

No passado, com o surgimento da propaganda, tais características notadamente positivas passaram a ser utilizadas com os mais diferentes propósitos pela indústria dos bens de consumo, com o intuito de agregá-las aos produtos e serviços, visto que a publicidade nos permite contar a mesma história sob diferentes formas e aspectos.

Para que seja melhor compreendida tal afirmação, buscamos produzir abaixo um esquema gráfico que permita melhor cognição e demonstração deste pensamento:

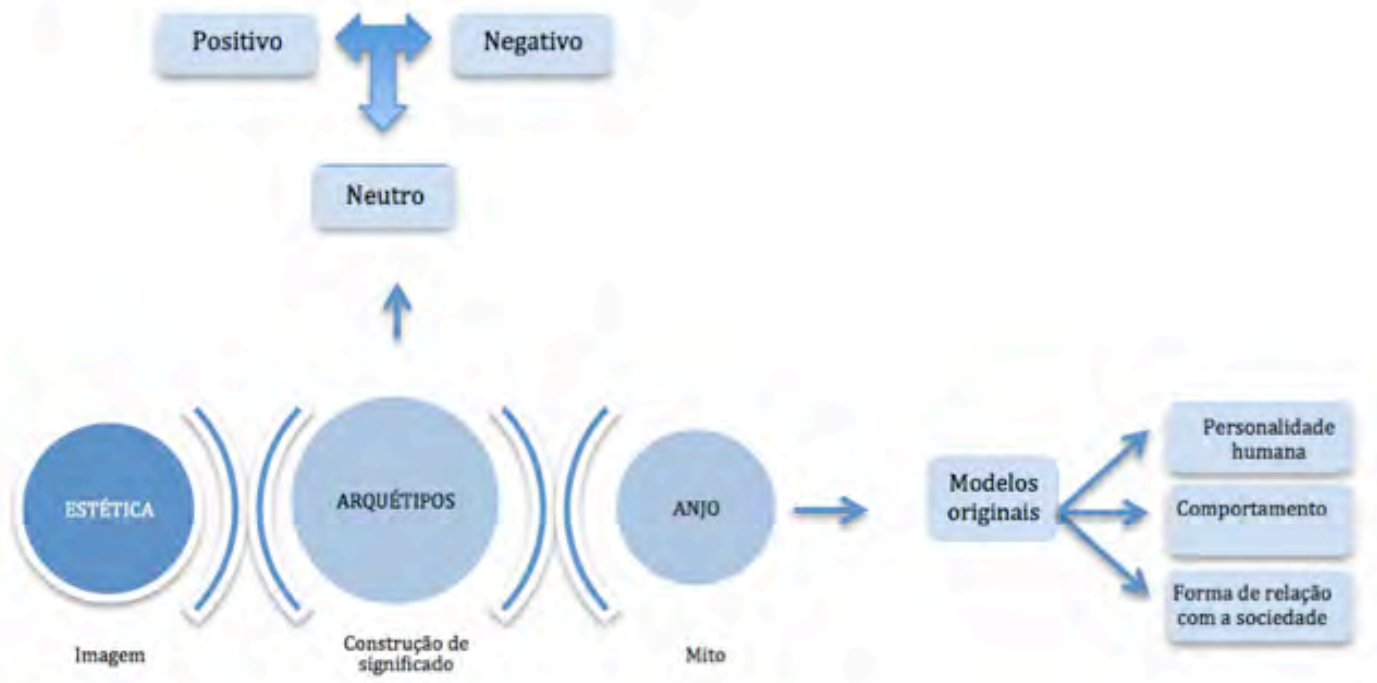

Gráfico 1: Esquema gráfico de construção do mito do anjo na publicidade - Criação da própria autora da pesquisa - Tatiana Anchieschi Gomes Mazzei

Para tanto, primeiramente é importante que compreendamos a importância do que vem a ser entendido como Estética, os arquétipos de Jung e sua aplicação na publicidade, bem como a fundamentação dos mitos, para que posteriormente seja possível o aprofundamento no esquema gráfico acima disposto. 
Neste sentido, o estudo da Estética mostra-se relevante, pois nos permite através da observação e pesquisa estabelecer conexões entre os distintos períodos da história da arte e seus diferentes estudiosos até o questionamento do que é ou não belo como forma de expressão.

É justamente quando gostos e preferências são levados em consideração como orientação, que nos deparamos com as criações utilizadas pelos profissionais de agências de publicidade, que se utilizam de atributos estéticos, acreditando ser estes os mais adequados para representação de diversos padrões e grupos de consumidores que determinadas marcas, produtos ou serviços almejam, levando em consideração suportes culturais e predileções pessoais dos indivíduos.

Ou seja, como conceituou o Prof. Dr. Victor Aquino Gomes Correa, Professor Titular de Publicidade da Escola de Comunicações e Artes da Universidade de São Paulo:

\footnotetext{
“(...) estética não apenas pode compreender as sensações de tudo que é percebido, como os conteúdos mediante os quais tudo é mostrado e, finalmente, a capacidade de cada ser humano de entender o que está percebendo e de garantir uma opinião pessoal a respeito". (AQUINO, 2012, p. 90)
}

Sendo assim, podemos afirmar que a publicidade, de forma muito particular, acabou por adquirir características próprias, e demonstra através de sua aplicação outras formas de expressão e criação distantes da arte.

Constrói o que Victor Aquino nomeia de estética própria, na qual são incorporados aos elementos da própria linguagem, quaisquer outras formas de representação sem que para isso haja preocupação com a sua localização cultural, ou seja, em que movimento estético artístico vislumbra no tempo-espaço, acabando por modificar por completo a obra original em recriações diversas e sem controle, fazendo surgir assim uma nova estética.

Nesta nova estética, permite-se utilizar os arquétipos criados por Carl Jung no estudo da psicologia, em que arquétipo não“(...) se trata de ideias herdadas, mas da possibilidade herdada das ideias. Não são aquisições individuais, mas, em geral, são comuns a todos os seres humanos, como se depreende de [sua] ocorrência universal”. (SHARP, 1991, p. 28-29) e ao aplicá-los à publicidade "os arquétipos se manifestam tanto no nível pessoal, através dos complexos, como coletivamente, como características de toda uma cultura.”. (SHARP, 1991, p. 30). 
Neste contexto, surge a mitologia que é a responsável por narrar um mesmo acontecimento de formas distintas, tais narrativas são a busca dos indivíduos e da sociedade por uma significação através dos tempos, em que todos precisam contar e compreender sua história.

Tais mitos tornam-se tão relevantes para a sociedade que acabam por se transformarem em símbolos, que esteticamente contribuem para a construção de arquétipos, responsáveis por produzir padrões de ideias e pensamentos de diferentes épocas. Sendo assim, podemos afirmar que:

"O campo simbólico se baseia nas experiências das pessoas de uma dada comunidade, num dado tempo e espaço. Os mitos estão tão intimamente ligados à cultura, a tempo e espaço, que, a menos que os mitos e as metáforas se mantenham vivos, por uma constante recriação através das artes, a vida simplesmente os abandona" - (CAMPBELL, 2004, p. 62)

Transpondo o já exposto para o esquema gráfico criado pela autora deste projeto de pesquisa, podemos afirmar que a estética auxilia-nos através da reprodução de diferentes formas imagéticas e metafóricas para a construção de significados e representações arquetípicas do mito do anjo, permitindo que isso ocorra de forma neutra ao abordar o tema sob a ótica do ser híbrido ou assexuado, positiva, quando o anjo se traveste de herói ou salvador, ou então negativa quando são mencionados os ambiciosos anjos caídos.

\subsection{O anjo e seus arquétipos}

$\mathrm{O}$ anjo, quando visto como arquétipo, estrutura-se como um ser dotado de sapiência, alado, envolto em uma aura de mistério e poder, por possuir entre suas qualidades a invisibilidade. Por tudo isto, é visto como um peregrino atemporal e psicólogo da vida humana, desempenhando principalmente o papel de herói e salvador.

Sendo assim, este ser celestial torna-se para a propaganda um modelo original que pode ser utilizado de diferentes formas em campanhas publicitárias, pois permite que lhe sejam aplicadas características tais que o aproximem da personalidade humana, imitando seus comportamentos e questionando ou não suas formas de relação com a sociedade. 
Ao analisarmos o quadro semântico criado por Mário Sérgio Teodoro da Silva Júnior em relatório de pesquisa de iniciação científica - “As relações semânticas entre as figuras do vampiro e do anjo na ficção contemporânea" - produzido para a UNESP em 2014, podemos afirmar que os arquétipos construídos para os anjos estão relacionados primeiramente com sua imagem tradicional bíblica, fundição primeira do imaginário deste ser mitológico e dela originam suas possíveis derivações.

TABELA 4 - ARQUÉTIPOS DE ANJOS

\begin{tabular}{|l|c|c|c|c|}
\hline & SERVIDÃO & BENEVOLENNCIA & HUMANIDADE & SEXUALIDADE \\
\hline Anjos Bíblicos & + & + & - & - \\
\hline Anjos Rebeldes & + & + & + & $+/-$ \\
\hline Anjos Anarquistas & - & - & - & - \\
\hline Anjos Políticos & + & - & - & - \\
\hline Anjos Bastardos & + & + & + & $+/-$ \\
\hline
\end{tabular}

Fonte: Quadro representativo sobre os arquétipos de anjos ${ }^{65}$

A referida tabela nos permite efetuar análise com base nos arquétipos de anjos e nas seguintes características:

- a servidão do anjo em relação ao seu compromisso com a vida celeste, os princípios divinos e os planos de Deus, fazendo referência à oposição existente entre inferno e céu e principalmente à fidelidade ou à revolta com o ser criador;

- a benevolência que diz respeito à postura do anjo em relação ao respeito à vida e suas percepções em relação à morte e se este prega a permanência ou a aniquilação da humanidade;

- a humanidade, ou seja, o desejo e anseio por sensações humanas;

- E por fim a sexualidade, visando vivenciar o amor carnal, a relação existente entre seres humanos cercada por vezes de artifícios e ambientes sensualizados.

A maioria dos anjos idealizados são benevolentes, felizes e adoram a Deus, porém não desejam ocupar o lugar dos seres humanos e portanto não possuem também o anseio pela

${ }^{65}$ Disponível em:

<www.academia.edu/8434953/As_relações_semânticas_entre_as_figuras_ficcionais_do_vampiro_e_do_anjo_na_ficção_cont emporânea> Acesso em 18/06/2014 
sexualidade, esta junção é que permite a criação do arquétipo bíblico do anjo, ou seja, qualquer característica que seja alterada a partir daí o transforma em personagem considerado humanizado ou caído dos céus.

Sendo assim, são utilizados tais arquétipos na publicidade e podemos classificálos da seguinte forma:

- O anjo bíblico é aquele que respeita os planos do criador e a vida. Não possui desejo pela vida carnal e, portanto, é assexuado. É pouco retratado na publicidade visto que nos anúncios o que se busca é dessacralizar o imaginário cristão;

- O anjo rebelde é caracterizado pela desobediência a Deus. Rebela-se em relação aos céus, porém possui relação amigável com o criador. A sexualidade, apesar de não ser o fator determinante, acaba por contextualizar este ser celestial;

- O anjo anarquista está relacionado a Lúcifer, pois não respeita os planos de Deus, inclusive revoltando-se contra ele. Portanto, não possui nenhum rastro de servidão ou benevolência e tão pouco desejo de humanizar-se, seu ódio é intensificado, por esta razão também não é comumente associado a emoções eufóricas como a sexualidade;

- $\mathrm{O}$ anjo político possui como traço principal: ser seguidor da vontade divina a qualquer custo, guerreando se necessário e, portanto, menos benevolente. Visa a manutenção das ordens celestiais e a preservação do paraíso não havendo por parte deste desejo por humanidade e sexualidade;

- Já o anjo bastardo é aquele que, apesar de servirem e respeitarem a Deus e a vida humana, desejam para si a vida terrestre e a relação amorosa com seres humanos. Trata-se de uma variação humanizada do anjo tradicional devido aos sentimentos exacerbados. Seria aqui o anjo caído, porém por razões não negativas. 


\subsection{Aspectos metodológicos}

Esta pesquisa dispôs como suporte metodológico a coleta de anúncios publicitários diversos que possuíssem em seu teor o personagem anjo. A forma de triagem foi realizada de maneira que o estudo pudesse utilizar a figura do anjo, qualquer que fosse seu papel, sendo este personagem principal ou apenas coadjuvante. Também não foram contempladas nacionalidades específicas, visto a dificuldade da coleta apenas no âmbito nacional, tendo a autora que dimensionar seu objeto para a internacionalidade para que a pesquisa pudesse obter o resultado desejado.

Vale ressaltar que para esta dissertação, foram levados em consideração apenas campanhas publicitárias e anúncios impressos coletados de revistas e da internet, pois se fossem incluídos também os filmes comerciais de 30", a pesquisa bibliográfica e eletrônica a tornariam por demais abrangente.

No quesito gênero em relação à sexualidade, não houve qualquer tipo de filtro ou distinção, levando em consideração todas as formas apresentadas, anjos assexuados, anjos masculinos, anjos femininos e anjos andrógenos.

Também optamos por não utilizar neste recorte anúncios que fizessem alusão apenas a demônios ou figuras diabólicas, pois apesar destes serem personagens antagônicos ao tradicional anjo bíblico, só foram aproveitadas campanhas que tivessem algum tipo de alusão ao bem contra o mal, ou que representassem a sua complementariedade.

Buscamos compreender nesta pesquisa quais as relações existentes entre o mito do anjo, suas representações estéticas, a criatividade em sua utilização, bem como qual a empregabilidade dada para este personagem nos anúncios publicitários visando a venda de produtos e serviços.

Para isso, foram realizadas análises pontuais de anúncios isoladamente ou em grupos quando pertinente, buscando em especial identificar primeiramente a "forma" de cada anjo representado e buscando compreender as suas qualidades estéticas empregadas à sua aplicação na publicidade. 


\subsection{Os anjos, o Marketing e sua utilização}

Os anjos e figuras aladas fizeram parte do imaginário coletivo tendo seu auge no chamado movimento "New Age" ${ }^{\text {"66 }}$, cujo objetivo era a busca da paz interior através de terapias holísticas. Apesar de tal movimento ter surgido entre os anos 60 e 70, foi no final dos anos 80 e início dos anos 90 que a figura do anjo passou a possuir um caráter comercial e publicitário. Surgiram os mais diversos produtos e serviços relacionados ao tema, contemplando de joias e roupas, a livros e lojas especializadas sobre o assunto.

Podemos comprovar a relevância desses seres celestiais e seu uso pela indústria da propaganda ao citarmos, por exemplo, a renomada marca de roupas esportivas Nike, cujo designativo é inspirado na deusa da mitologia greco-romana de mesmo nome e na qual se utiliza para representação imagética um logotipo semelhante a uma asa, homenageando a deusa alada da vitória.
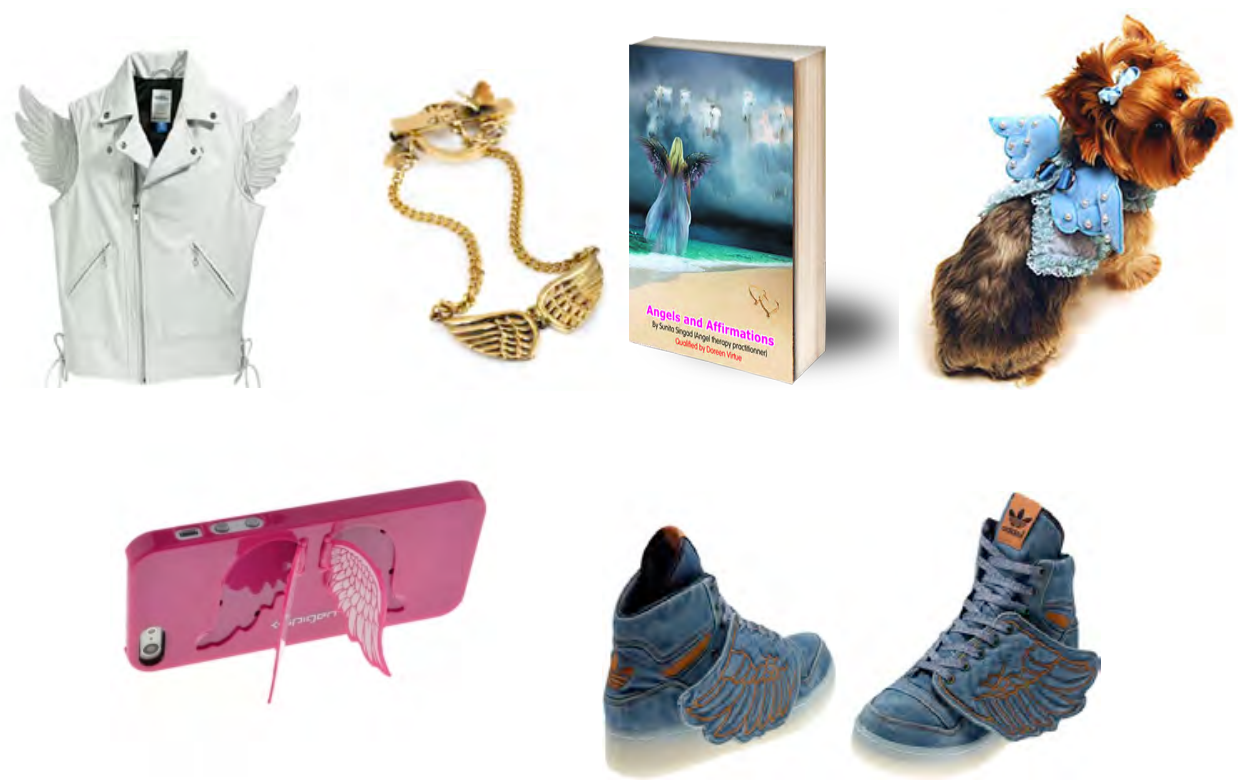

Figura 62: Exemplos de produtos baseados na figura do Anjo.

${ }^{66}$ Também conhecido por "Nova Era" trata-se de um movimento espiritual ocidental surgido na segunda metade do século XX. Seus preceitos foram fundamentados em tradições espirituais e metafísicas que abordavam temas como autoajuda, psicologia motivacional, saúde holística, parapsicologia, pesquisa da consciência e física quântica. 
O tema anjo não ficou confinado apenas ao movimento "New Age". Mostrou-se relevante como fenômeno mundial ao ser abordado na edição de dezembro de 1993 da revista americana Time, permitindo que estes seres alados celestiais ilustrassem sua matéria de capa.

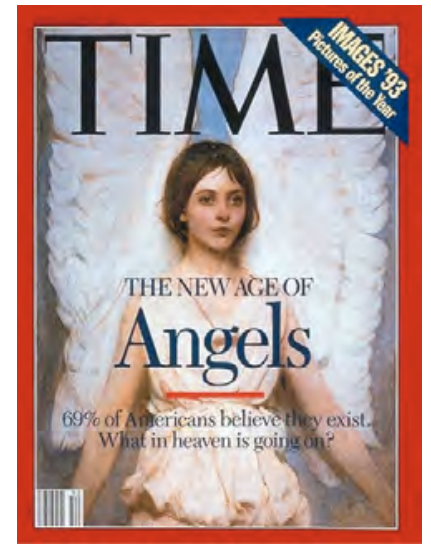

Figura 63: Capa Revista Time - Edição Dez/1993 - Ilustração: Abbott Handerson Thayer ${ }^{67}$

Passados mais de vinte anos dessa primeira pesquisa, é possível afirmar que o anjo permanece sendo um mito moderno. Isto porque, pesquisa online realizada pelo Harris Polls Institute, da Nielsen Company, entre 13 e 18 de novembro de 2013, demonstra levantamentos coletados sobre o assunto, conforme é possível perceber no Gráfico 2, abaixo:

Gráfico 2 - O que as pessoas acreditam ou não?

TABLE 1a WHAT PEOPLE DO AND DO NOT BELIEVE IN

"Please indicate for each one if you believe in it, or not"

\begin{tabular}{|c|c|c|c|c|c|c|c|c|c|}
\hline & & \multirow{2}{*}{$\begin{array}{c}\text { Believe } \\
\text { In }\end{array}$} & \multirow{2}{*}{\begin{tabular}{|c|} 
Don't \\
Believe In
\end{tabular}} & \multirow{2}{*}{$\begin{array}{l}\text { Not } \\
\text { Sure }\end{array}$} & \multicolumn{4}{|c|}{ Believe In } & \multirow{2}{*}{$\begin{array}{c}\text { Change } \\
2005-2013\end{array}$} \\
\hline & & & & & 2005 & 2007 & 2009 & 2013 & \\
\hline God & $\%$ & 74 & 12 & 14 & 82 & 82 & 82 & 74 & -8 \\
\hline Miracles & $\%$ & 72 & 15 & 13 & 79 & 79 & 76 & 72 & -7 \\
\hline Heaven & $\%$ & 68 & 16 & 15 & 75 & 75 & 75 & 68 & -7 \\
\hline Jesus is God or the Son of God & $\%$ & 68 & 18 & 14 & 72 & 72 & 73 & 68 & -4 \\
\hline Angels & $\%$ & 68 & 18 & 15 & 74 & 74 & 72 & 68 & -6 \\
\hline The resurrection of Jesus Christ & $\%$ & 65 & 19 & 16 & 70 & 70 & 70 & 65 & -5 \\
\hline Survival of the soul after death & $\%$ & 64 & 16 & 20 & 69 & 69 & 71 & 64 & -5 \\
\hline Hell & $\%$ & 58 & 25 & 18 & 62 & 62 & 61 & 58 & -4 \\
\hline The Devil & $\%$ & 58 & 26 & 16 & 62 & 62 & 60 & 58 & -4 \\
\hline The Virgin birth (Jesus born of Mary) & $\%$ & 57 & 24 & 20 & 60 & 60 & 61 & 57 & -3 \\
\hline Darwin's theory of evolution & $\%$ & 47 & 29 & 25 & 42 & 42 & 45 & 47 & +5 \\
\hline Ghosts & $\%$ & 42 & 37 & 21 & 41 & 41 & 42 & 42 & +1 \\
\hline Creationism & $\%$ & 36 & 31 & 33 & 39 & 39 & 40 & 36 & -3 \\
\hline UFOs & $\%$ & 36 & 35 & 29 & 35 & 35 & 32 & 36 & +1 \\
\hline Astrology & $\%$ & 29 & 50 & 21 & 29 & 29 & 26 & 29 & - \\
\hline Witches & $\%$ & 26 & 54 & 19 & 31 & 31 & 23 & 26 & -5 \\
\hline Reincarnation - that you were once another person & $\%$ & 24 & 49 & 27 & 21 & 21 & 20 & 24 & +3 \\
\hline
\end{tabular}

Note: Percentages may not add up exactly to $100 \%$ because of rounding

- indicates no change

Gráfico 2: O que as pessoas acreditam ou não? - Pesquisa online realizada pelo Harris Polls Institute $-2013^{68}$

${ }^{67}$ Disponível em: <http://content.time.com/time/covers/0,16641,19931227,00.html> Acesso em 23/08/14

${ }^{68}$ Disponível em:

<http://www.harrisinteractive.com/NewsRoom/HarrisPolls/tabid/447/ctl/ReadCustom\%20Default/mid/1508/ArticleId/1353/

Default.aspx> Acesso em: 23/08/14 
Ao interpretarmos os dados, notamos informações relevantes e que confirmam a afirmação anterior, visto que os anjos são a $5^{\text {a }}$. opção apontada pelos entrevistados quando questionados no que acreditam, ficando à frente de itens científico-tecnológicos, tais como a Teoria da Evolução de Darwin.

No entanto, vale ressaltar que nos últimos oito anos, há uma queda representativa de $6 \%$, que ainda assim não interfere em sua colocação no ranking, porém demonstrando que as pessoas estão mais bem informadas ou então mais descrentes quando o assunto é religião, na qual a mesma Teoria da Evolução de Darwin apontada acima e os UFO's (OVNI's em português) ganham força e adeptos de sua existência.

Já no Gráfico 3 apresentado adiante, podemos perceber que quando o assunto é idade, o percentual apresentado pelas gerações $X^{69}(71 \%)$, Baby Boomers ${ }^{70}(73 \%)$ e Matures $^{71}$ (68\%), não apresenta grandes discrepâncias, porém vale observar que entrevistados com idades entre 18 e 36 anos possuem os menores índices aferidos. Tal fato se deve ao crescente uso da tecnologia pelos mais jovens e ao afastamento cada vez maior destes dos preceitos religiosos e da orientação familiar.

O mesmo notamos quando a relação é feita levando em consideração a ideologia política. Entrevistados que possuem preferência pelo Partido Republicano apresentam os maiores percentuais $(77 \%)$, pois segundo o portal Terra, geralmente são caracterizados como pessoas mais religiosas, defensoras de políticas conservadoras e em defesa da família e que se opõem ao casamento entre homossexuais ou ao financiamento de abortos com recursos públicos, enquanto seus oponentes, os simpatizantes ao Partido Democrata, apresentam-se como uma organização de centro-esquerda, com a proposta de equilibrar o capitalismo com programas sociais, defendendo o direito das minorias como, por exemplo, o aborto.

\footnotetext{
${ }^{69}$ Geração X: pessoas nascidas entre 1966 e 1980, com idade aproximada entre 32 e 46 anos. Os membros dessa geração tendem a preferir resultados finais de alta qualidade ao invés de quantidade, estabelecem e cumprem metas e são muito produtivos. Tentam equilibrar o trabalho e a vida, buscando por exemplo horários de trabalho flexíveis. Ficam confortáveis em cargos de autoridade, porém não se impressionam com títulos, valorizam a diversidade étnica e amam a independência.

70 Baby Boomers: geração dos nascidos entre 1946 e 1965. São pessoas com aproximadamente 47 a 66 anos de idade. Possuem como características permanecer longas horas no escritório, incluindo noites e finais de semana, construção de carreira a longo prazo e lealdade para com a empresa em que atuam. Respeitam autoridade e são políticos ao buscar encontrar soluções para problemas.

${ }^{71}$ Matures: Também chamados de veteranos, são membros de uma geração nascida antes de 1946. Conformados e disciplinados, possuem respeito pela autoridade. São tradicionais em aspectos familiares e poupadores quando o assunto é dinheiro, pois buscam segurança.
} 


\section{Gráfico 3 - O que as pessoas acreditam ou não?}

(Por geração e Ideologia Política)

\section{TABLE 1b \\ WHAT PEOPLE BELIEVE IN}

By Generation \& Political Party

"Please indicate for each one if you believe in it, or not"

Base: All Adults

\begin{tabular}{|c|c|c|c|c|c|c|c|c|}
\hline & \multirow[b]{2}{*}{ Total } & \multicolumn{4}{|c|}{ Generation } & \multicolumn{3}{|c|}{ Political Party } \\
\hline & & $\begin{array}{c}\text { Echo } \\
\text { Boomers } \\
(18-36)\end{array}$ & \begin{tabular}{|c|} 
Gen \\
Xers \\
$(37-48)$
\end{tabular} & $\begin{array}{c}\text { Baby } \\
\text { Boomers } \\
(49-67)\end{array}$ & $\begin{array}{c}\text { Matures } \\
(68+)\end{array}$ & Republicans & Democrats & Independents \\
\hline & $\%$ & $\%$ & $\%$ & $\%$ & $\%$ & $\%$ & $\%$ & $\%$ \\
\hline God & 74 & 64 & 75 & 81 & 83 & 87 & 72 & 70 \\
\hline Miracles & 72 & 65 & 74 & 76 & 78 & 83 & 71 & 68 \\
\hline Heaven & 68 & 62 & 68 & 74 & 73 & 80 & 66 & 65 \\
\hline Jesus is God or the Son of God & 68 & 58 & 67 & 74 & 75 & 83 & 64 & 62 \\
\hline Angels & 68 & 59 & 71 & 73 & 68 & 77 & 66 & 64 \\
\hline The resurrection of Jesus Christ & 65 & 55 & 63 & 72 & 74 & 80 & 60 & 60 \\
\hline Survival of the soul after death & 64 & 59 & 63 & 68 & 67 & 74 & 63 & 60 \\
\hline Hell & 58 & 54 & 58 & 60 & 63 & 74 & 53 & 53 \\
\hline The Devil & 58 & 53 & 60 & 60 & 60 & 69 & 55 & 54 \\
\hline The Virgin birth (Jesus born of Mary) & 57 & 48 & 52 & 64 & 67 & 72 & 52 & 53 \\
\hline Darwin's theory of evolution & 47 & 49 & 48 & 45 & 43 & 36 & 52 & 51 \\
\hline Ghosts & 42 & 44 & 46 & 46 & 24 & 43 & 45 & 39 \\
\hline Creationism & 36 & 33 & 35 & 38 & 37 & 49 & 30 & 34 \\
\hline UFOs & 36 & 36 & 36 & 37 & 30 & 36 & 37 & 35 \\
\hline Astrology & 29 & 33 & 34 & 26 & 23 & 29 & 31 & 27 \\
\hline Witches & 26 & 27 & 29 & 28 & 18 & 27 & 26 & 25 \\
\hline $\begin{array}{l}\text { Reincarnation - that you were once } \\
\text { another person }\end{array}$ & 24 & 27 & 25 & 23 & 13 & 18 & 30 & 18 \\
\hline
\end{tabular}

Gráfico 3: Gráfico No.3 da Pesquisa realizada pelo Harris Polls Institute - Pesquisa online $-2013^{72}$

Valendo-se da compreensão de dados acima, a publicidade, conhecedora da crença da sociedade contemporânea na existência da figura do anjo e sabedora do desejo desta na obtenção das qualidades mais nobres ditadas por este, passou a utilizar com maior frequência as características e qualidades presentes neste personagem mítico, a fim de obter lucros e notoriedade para as marcas.

Em um célere retrospecto acerca de tudo o que já foi veiculado com a presença da figura do anjo, muitas vezes nos defrontamos com anúncios nem sempre eficazes e por vezes de gosto duvidoso. É possível encontrar de tudo. São anúncios de produtos alimentícios, perfumes, passando pela venda de cigarros e bebidas alcóolicas ou então peças industriais com fins bastante específicos.

Podemos aqui nos fazer valer do ensaio "A Obra de Arte na Época de sua Reprodutibilidade Técnica" de Walter Benjamin, que prega a "perda" da aura de objetos e

\footnotetext{
${ }^{72}$ Disponível em:

<http://www.harrisinteractive.com/NewsRoom/HarrisPolls/tabid/447/ctl/ReadCustom\%20Default/mid/1508/ArticleId/1353/ Default.aspx> Acesso em: 23/08/14
} 
obras de arte individualizados, que a partir do momento em que passam a ser reproduzidos em larga escala, através de técnicas de reprodução como o cinema e a publicidade, são destituídos do seu caráter de raridade, afastando-se da atmosfera aristocrática e religiosa que antes os pertencia.

Algo que anteriormente era tratado como culto e nobre passa a ser dessacralizado e acaba por atingir dimensões sociais. Dimensões estas que possuem ligação com as transformações da sociedade e as variações da percepção estética. E são essas transformações da sociedade e as variações estéticas que foram empregadas nos anúncios coletados que veremos nas páginas a seguir.

Para isso, a partir deste ponto serão realizadas análises pontuais seguindo o seguinte raciocínio, primeiramente serão apresentados anúncios que representem esteticamente as características natas e habituais dos anjos tais como a proteção e a bondade. Em um segundo momento, partiremos para uma análise relacionando-os a fatores como sexualidade e gênero, quando, por exemplo, são utilizados em campanhas publicitárias anjos sensualizados ou sexualizados. Posteriormente, serão analisados anúncios que demonstrem em seu teor características mundanas ou aspectos físicos e psicológicos dos humanos, porém atribuídos ao anjo, para depois identificarmos aqueles que fazem alusões a atributos angelicais que resultam em expressões que remetem a atributos positivos angelicais tais como pé de anjo ou cabelo de anjo, para por fim citar, demonstrar e analisar aqueles que possuem a presença do personagem anjo de maneiras adversas e antagônicas como por exemplo a luta do bem contra o mal ou a presença do anjo e do demônio.

\subsection{Os anjos na publicidade}

Na publicidade, muitos são os adjetivos dados aos anjos e tal conotação depende da maneira estética como estes são representados em anúncios. Atualmente, a figura do anjo tem sido utilizada para comercializar uma infinidade de produtos com as mais diversas características, sendo utilizado como referência para a venda de produtos como perfumes e cigarros até a divulgação de peças muito específicas para funcionamento de relógios. 

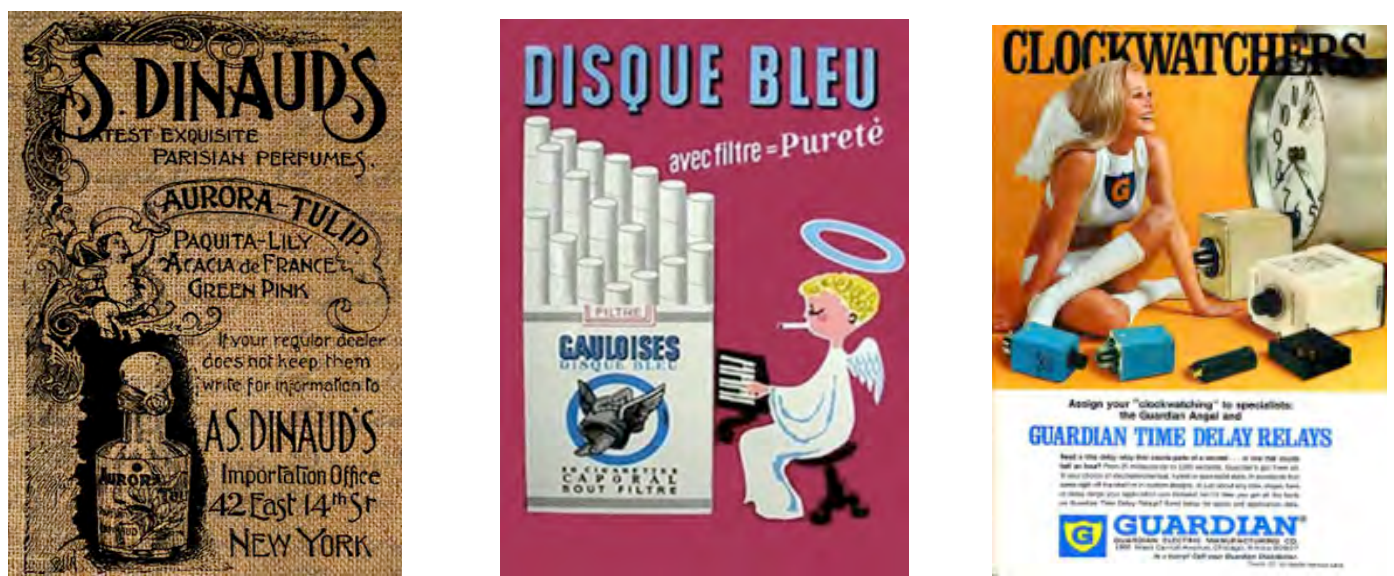

Figura 64: Anúncios publicitários antigos com a presença da figura do anjo

Quando genericamente ilustrados, ao representá-los através da figura de uma criança, busca-se atribuí-los características positivas como inocência, pureza e virtude, quando lhes é dado aspectos de beleza e iluminação, transformam-se em mensageiros e são exibidos como guerreiros protetores em nome de Deus e basta que para isso brilhem, vistam armaduras ou os ilustrem empunhando espadas.

Antes de prosseguirmos na análise dos câmbios estéticos pelos quais a figura do anjo passou com o decorrer dos séculos e com as inúmeras mudanças sociais e culturais pelas quais o mundo atravessou, faz-se necessário um breve mergulho e entendimento no universo destes seres.

Seja qual for a religião e independente do nome dado aos anjos, existem diversas crenças que aceitam sua existência como fato, porém, não necessariamente que suas características e funções sejam semelhantes. Isto porque, apesar da semelhança entre os mitos e em função da transmissão para estes povos ter sido feita de forma oral na Antiguidade, cada um destes pegou para si um fragmento da mitologia de outro e a partir daí construíram a sua própria de acordo com as adaptações inerentes às suas culturas. Sendo assim, não raro é encontrarmos na publicidade também uma gama de diferentes representações da figura do anjo.

\subsubsection{Anjos como portadores de proteção e segurança}

A forma mais habitual a qual a figura do anjo é retratada na publicidade são aquelas que comumente remetem aos aspectos como bondade e proteção e as quais 
geralmente os aspectos estéticos são mais conhecidos pela sociedade, sendo muitas vezes reportados através de ilustrações contendo a presença de uma criança ou jovem alado de cabelos cacheados.

Tais anúncios trazem em seu teor conselhos e recomendações para que o leitor sinta-se ou mantenha-se protegido ou creia na bondade de um ser superior que zela por sua segurança. Muitos deles inclusive apelam para o minimalismo, inserindo no contexto da propaganda a menor quantidade possível de elementos, deixando a cargo do anjo e sua representação a transmissão da mensagem desejada.

É possível notar também que o fator segurança, bastante evidenciado nos anúncios automobilísticos, possui constantemente a presença do anjo não mais retratado como um ser mitológico, mas sim transmitindo suas características ao carro, neste caso um objeto, atribuindo-lhe aspectos de proteção, fazendo com que o consumidor associe o fato de que comprando determinado carro, este o manterá mais seguro do que qualquer outro.

Em campanha publicitária criada pela Paim Comunicação para o Ministério Público do Trabalho em 2014, evidencia o aspecto segurança ao utilizar a figura do anjo em seus anúncios e junto a frase "Não espere milagres do seu anjo da guarda. Use equipamentos de segurança no trabalho".
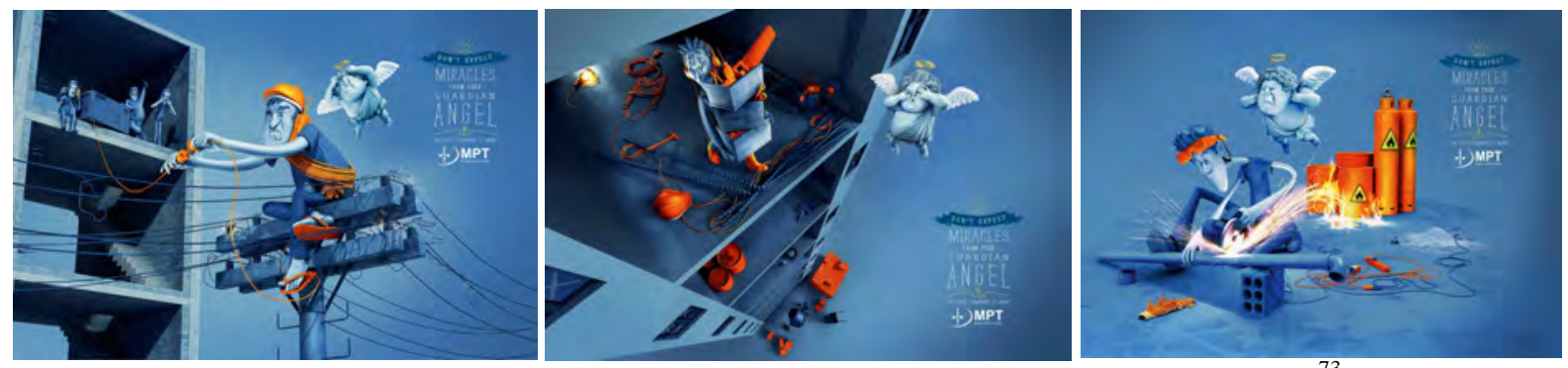

Figura 65: Anúncio para Ministério Público do Trabalho - Paim Comunicação ${ }^{73}$

Ou ainda podem ser percebidos os mesmos aspectos em anúncios criados em 2013 para a Cemig - Companhia Energética de Minas Gerais pela agência de publicidade Perfil 252 e amplamente veiculados em rádio, TV, outdoor e mídia impressa, em que um cauteloso anjo Gabriel alerta a população sobre os perigos de efetuar reparos na rede elétrica sem o devido conhecimento, sempre acompanhado do slogan "Não dê tanto trabalho pro seu anjo da guarda".

\footnotetext{
${ }^{73}$ Disponível em: <http://38.126.102.63/media/print/ministerio_publico_do_trabalho_guardian_angel_3?size=original>
} 

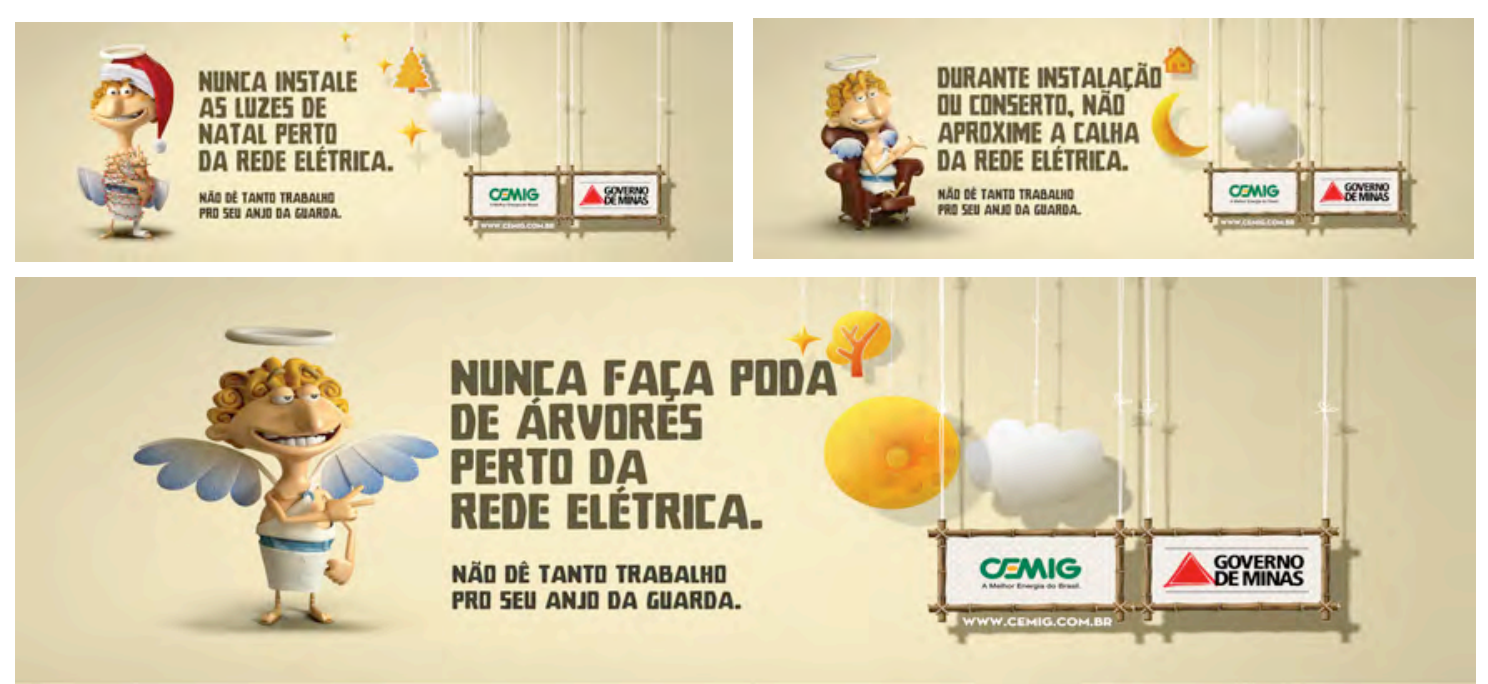

Figura 66: Anúncios para a Companhia Energética de Minas Gerais - Perfil $252^{74}$

Tal aspecto é também empregado em anúncios publicitários quando o assunto está relacionado à segurança das crianças. Muitos deles fazem alusão ao fato de a figura do anjo poder voar e alertando que mesmo as crianças sendo consideradas "anjinhos", cabe aos adultos cuidar para que nada de mau lhes ocorra visto que não possuem tal dom.

Este tipo de argumentação é comumente utilizado por concessionárias de estradas de rodagem e órgãos federais que zelam pela segurança e saúde dos passageiros de automóveis em autoestradas.

É o que notamos no anúncio criado pela agência curitibana Terremoto Propaganda para a concessionária Ecovias alertando sobre a importância do uso da cadeirinha infantil em carros para garantir a segurança das crianças que viajam.

Como se a imagem de um anjo fizesse a marcação de um corpo de criança acidentado no asfalto e com os dizeres "Sua criança não nasceu para voar. Use assento infantil", envia o recado aos pais desatentos ou não cautelosos sobre a necessidade da segurança infantil. 


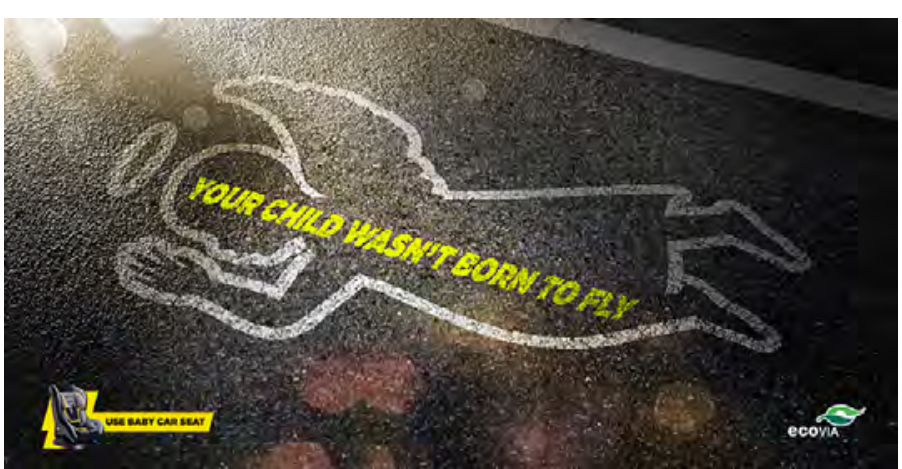

Figura 67: Anúncio Ecovias alertando sobre o uso de cadeirinha infantil - Terremoto Propaganda ${ }^{75}$

O mesmo apelo foi adotado pela Autoridade de Saúde de Abu Dhabi, denominada HAAD - Health Autority Abu Dabhi, órgão que regulamenta o setor de saúde dos Emirados Árabes e que busca garantir a excelência dos serviços para a comunidade através de constantes monitoramentos.

Nos anúncios criados pelo grupo BPG - Bates Pan Gulf em fevereiro deste ano e veiculados na mídia impressa, mostram em três diferentes versões crianças sendo lançadas ao alto, seja por algum adulto, cama elástica ou trampolim e quando estas se encontram em suspensão, atrás delas, uma formação de nuvens simulam asas, dando-lhes características estéticas de anjo. Logo abaixo os dizeres complementam o anúncio com a seguinte mensagem: "Crianças gostam de voar por diversão. Não as deixe voar na realidade. Assentos infantis salvam vidas e reduzem os ferimentos em acidentes de trânsito."
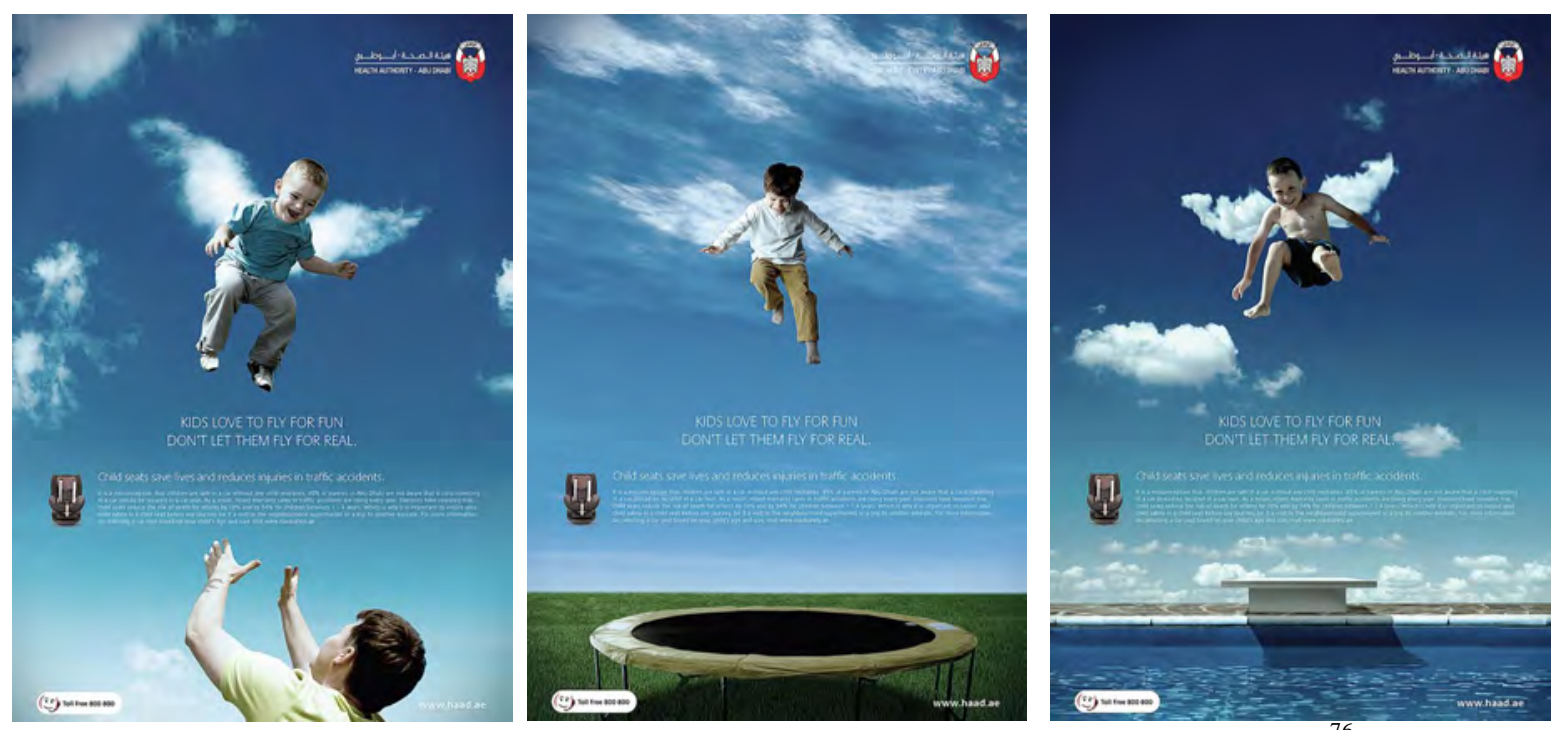

Figura 68: Anúncios para HAAD - Heatlh Autority Abu Dabhi - BPG Group ${ }^{76}$

\footnotetext{
${ }^{75}$ Disponível em: <https://www.behance.net/gallery/17527267/Ecovia-Cadeirinha-Anjos> Acesso em: 15/03/2015

${ }^{76}$ Disponível em: <http://www.coloribus.com/adsarchive/prints/health-authority-abu-dhabi-haad-flying-angels-1-20074405> Acesso em: 15/03/2015
} 
Ainda relacionando a figura do anjo ao quesito segurança e aproveitando-nos da área automobilística já citada anteriormente, vale ressaltar que este setor também zela e muito por este atributo sendo um dos mais evidenciados em anúncios como benefício aos consumidores de automóveis.

Neste caso, o que notamos neste tipo de campanha publicitária é a presença do minimalismo, na qual através de pouquíssimos elementos busca-se passar uma mensagem, ressaltando principalmente o automóvel e seus atributos.

Em anúncio criado pela agência W/Brasil para a Mercedes Benz em 2002, evidenciou-se apenas o carro, em um fundo azul imitando o céu e atribuíram ao automóvel com forte luminosidade os aspectos de segurança, como se este próprio fosse um anjo, com suas portas abertas simulando asas. Logo abaixo os dizeres complementam a mensagem com o texto redigido: "Classe A 2002. O anjo da guarda disfarçado".

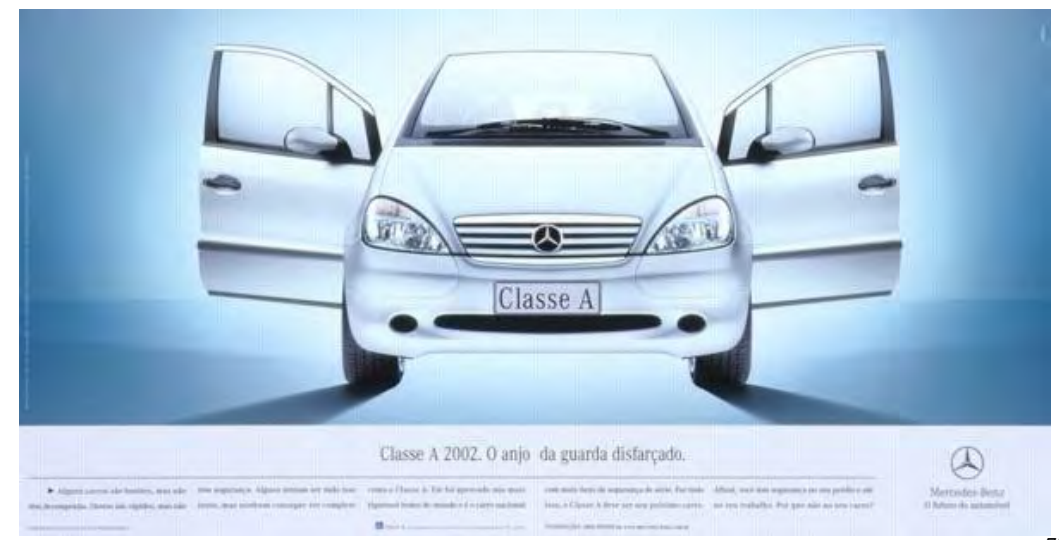

Figura 69: Anúncio do carro Classe A 2002 da Mercedes Benz - W/Brasil ${ }^{77}$

Em anúncio ainda mais minimalista, sem qualquer texto escrito e contendo apenas uma foto da marca Chrysler, a figura do anjo surge como um complemento do logotipo da empresa. Criado pela agência de publicidade BBDO Puerto Rico em 2005, evidenciando sem a necessidade de qualquer repertório maior quais são as qualidades do automóvel.

Aproveitando-se das "asas" do logotipo da Chrysler, que fazem alusão à velocidade, em função também da qualidade do carro de luxo, todos os demais atributos do anjo são inseridos a sua volta, como a bata e a auréola.

\footnotetext{
${ }^{77}$ Disponível em: http://files1.coloribus.com/files/adsarchive/part_409/4097855/file/a-class-guardian-angel-small-55708.jpg Acesso em: 15/03/2015
} 


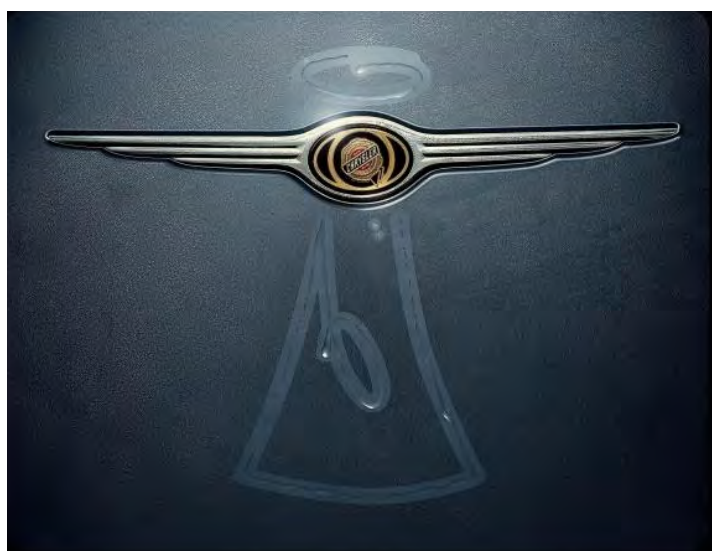

Figura 70: Anúncio para marca automotiva Chrysler - BBDO Puerto Rico ${ }^{78}$

Outro apanágio bastante evidenciado na publicidade em relação à figura do anjo é a proteção. Este tipo de predicado é utilizado à exaustão por companhias de seguro, empresas de transporte e também pela indústria têxtil entre outros.

Procurando demonstrar a qualidade dos seus produtos, a empresa Polarguard, especializada em roupas e acessórios criados para serem utilizados durante frio extremo e neve, aprovou campanha publicitária veiculada em 2008 e apresentada pela agência alemã KNSK.

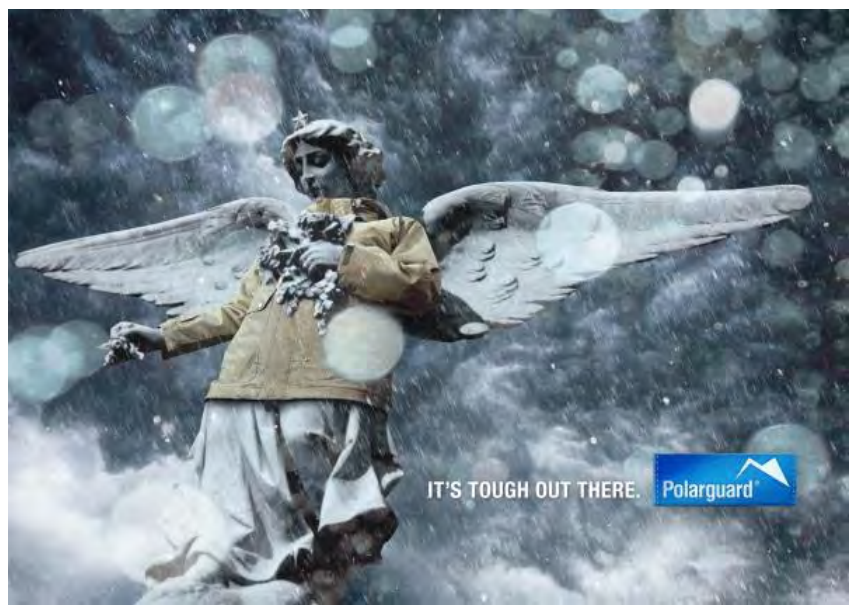

Figura 71: Anúncio para marca de roupas para neve Polarguard - Agência KNSK ${ }^{79}$

Nela, em meio a uma nevasca, é retratado um anjo em cima de um monumento, porém ao invés de estar somente aparente o cimento e o mármore de que é composto, esta

\footnotetext{
${ }^{78}$ Disponível em: <http://www.advertolog.com/chrysler/print-outdoor/angel-7937055> Acesso em: 15/03/2015

${ }^{79}$ Disponível em: <http://files2.coloribus.com/files/adsarchive/part_1022/10225855/file/outdoor-clothing-angel-small94725.jpg> Acesso em: 15/03/2015
} 
estátua surge envolta em um casaco da marca, permitindo que o anjo transmita além do atributo proteção, o conceito de conforto, tamanha a delicadeza da foto.

Assinando a peça com o slogan "É difícil lá fora", a agência ressalta a necessidade da compra de roupas especiais e de qualidade para proteção do frio, buscando inserir a Polarguard à frente de suas concorrentes e incitando seus consumidores a investirem na marca.

Outra marca que buscou utilizar da figura do anjo atrelada à proteção como predicado foi a empresa de suporte para transportes seguros Boxman.

Em anúncio criado em 2014 pela agência M\&C Saatchi Abel Johannesburg, também fazendo uso do minimalismo e sem qualquer tipo de texto, um anjo de porcelana trincada é inserido no anúncio e ao seu lado uma caixa com plásticos bolha da empresa evidencia a necessidade de se efetuar transportes seguros protegendo os bens dos consumidores.

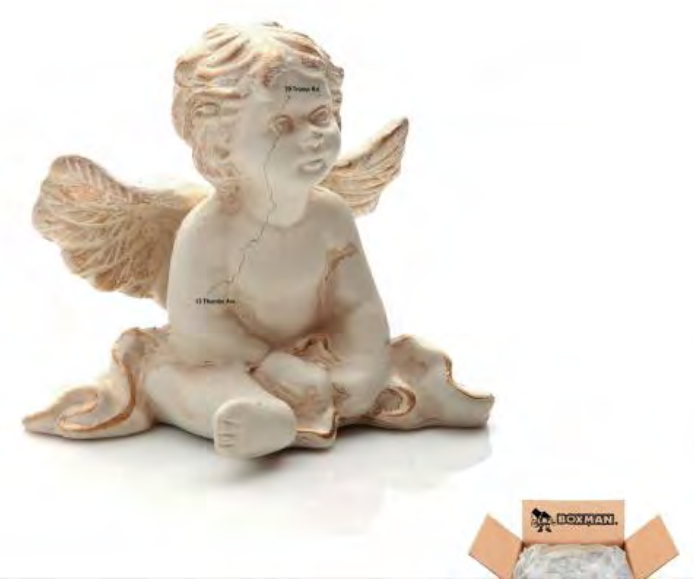

Figura 72: Anúncio para empresa de transportes seguros Boxman - M\&C Saatchi ${ }^{80}$

\footnotetext{
${ }^{80}$ Disponível em: http://www.coloribus.com/adsarchive/prints/boxman-angel-19469255/ Acesso em: 15/03/2015
} 


\subsubsection{Anjos dotados de sexualidade e gênero}

Contrariando o que muitos venham a pensar, nem sempre a figura do anjo foi retratada como criança, apesar de ter em Eros, filho de Vênus e mais conhecido por Cupido uma de suas maiores representações.

O passar dos anos e as mudanças na sociedade fizeram com que a publicidade atribuísse a este ser celestial características que acabaram por sexualizá-lo ao inserir sua figura em anúncios cujo teor mencionassem qualquer ligação com a luxúria e a libertinagem ou a sensualidade e o erotismo.

Também acabou permitindo que o anjo fosse classificado dentro do conceito de gênero, referindo-se muitas vezes à identidade adotada pelo mito e sua representação estética como figura masculina, feminina, homossexual e assexuada nos anúncios publicitários.

Partindo de um infográfico ${ }^{81}$ elaborado pela autora desta pesquisa, buscamos evidenciar a evolução estética da figura do anjo na publicidade nos quesitos sexualidade e gênero através de exemplos de anúncios coletados durante a pesquisa.

Tal representação esquemática foi criada no início do projeto, buscando orientar a coleta e posterior seleção e descarte dos anúncios com base nos levantamentos e percepções da autora.

Possuindo como ponto de partida a origem da figura estética do anjo e tendo seu início nas menções de sua existência nas escrituras, livros sagrados e na mitologia, passando por suas diferentes representações artísticas na História da Arte, iniciamos o processo de análise levando em conta, neste primeiro momento, seu caráter assexuado e andrógeno, ou seja, sua herança bíblica.

\footnotetext{
${ }^{81}$ Infográficos são representações visuais gráficas, muitas vezes complexas, que facilitam a compreensão de conteúdos, onde apenas texto escrito dificultaria o entendimento. Costumam ser caracterizados pela união de textos breves com representações figurativas e esquemáticas.
} 


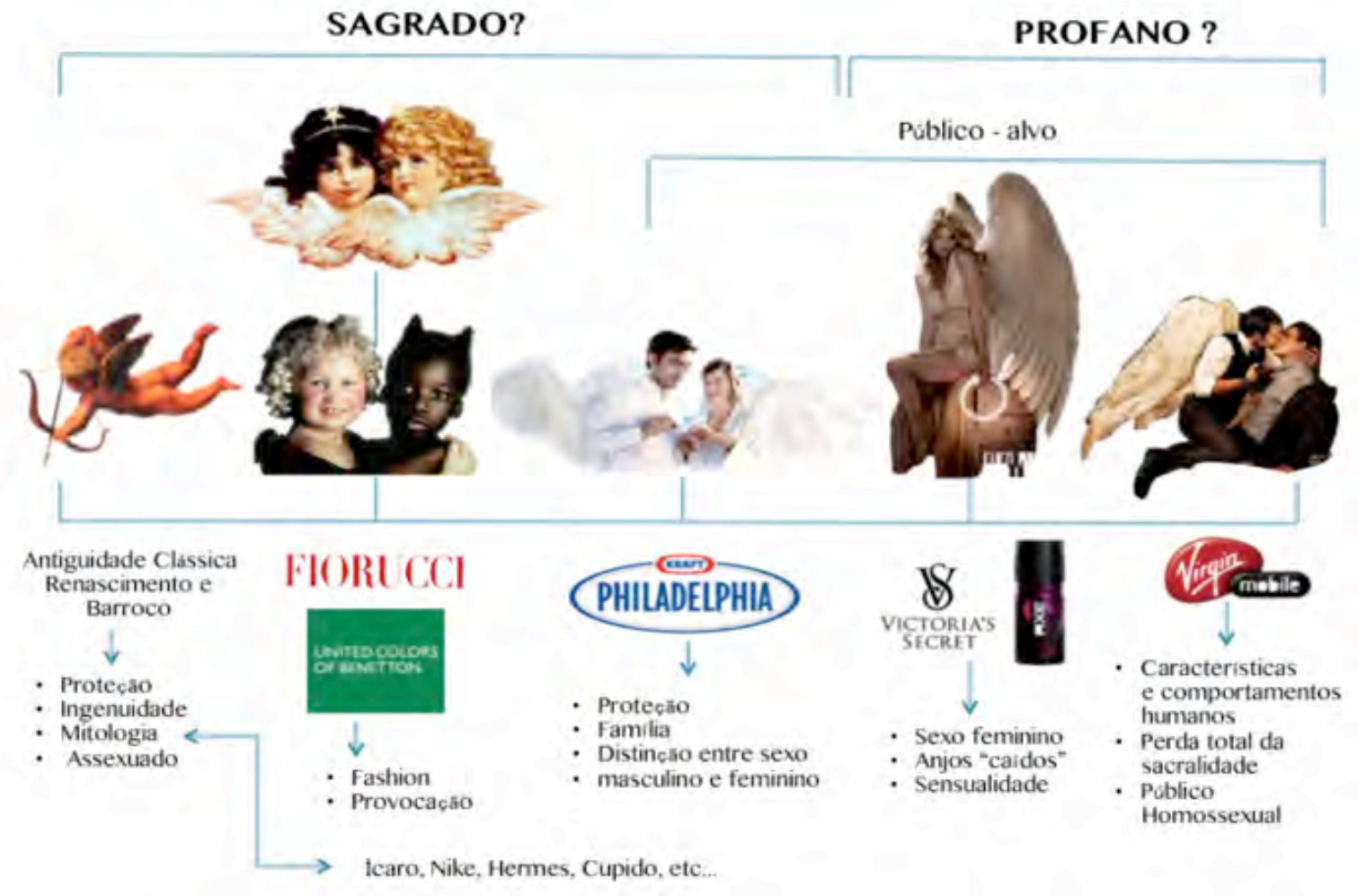

Figura 73: Evolução estética do anjo em relação a sexualidade e gênero. MAZZEI, Tatiana A. Gomes. 2013

Porém, com o advento da publicidade, estes mesmos seres passaram a ser relacionados à infância e como tal foram representados em campanhas e anúncios, porém sem perder seu caráter sacro.

Neste ínterim, surgem propagandas que mostram o anjo como personagem mítico que possui uma distinção de gênero, classificando-os como anjos masculinos e anjos femininos, permitindo inclusive que sejam representados como família, inserindo um aspecto antes não atribuído a eles que é a sexualidade.

Com a exploração dos corpos femininos e da sensualidade na publicidade, posteriormente notamos uma evolução estética, na qual a figura do anjo passou mais constantemente a ser representada de maneira feminina para melhor utilização do apelo sexual das campanhas criadas pelas agências de propaganda e a dessacralização por completo do mito.

Neste primeiro momento, são exibidos então anjos caídos pela tentação carnal e belíssimas anjas vestindo lingeries, iniciando o processo em que a parte profana se apropria da figura do anjo na publicidade.

Com as mudanças na sociedade contemporânea e a aceitação ainda velada de determinados comportamentos humanos, passam a surgir também anúncios voltados para 
grupos mais restritos tais como os homossexuais. Através da inclusão de fortes apelos sensuais ou a inserção de diferentes gêneros em distintas versões de uma mesma campanha, passa a existir, onde antes havia apenas dois, uma terceira opção de modelo de vida focando o poder de compra deste público em especial.

A partir do anteriormente disposto, é possível ensaiar algumas utilizações estéticas sobre os anúncios publicitários publicados até hoje com fins comerciais.

Iniciando nosso ensaio estético sobre a figura do anjo a partir de Cupido, que obteve uma contaminação da forma nas pinturas renascentistas sendo comumente representado por uma criança alada, seminua, que empunha nas mãos um arco e flecha e simboliza o amor, podemos notar que o Cupido para a publicidade possui inúmeras funções, pois trata-se de uma figura fecunda podendo representar muitas coisas, entre elas a força poderosa que permite a união dos casais e consequentemente a perpetuação das raças.

A fundamentação de Cupido é bem mais complexa do que se imagina, pois se tomarmos como ponto de partida a obra O Banquete de Platão, onde Pênia uniu-se a Póros ${ }^{82}$ e juntos acabaram por criar Cupido, chegaremos a um ser tão perfeito, que em função de seu enorme aprimoramento viu-se obrigado a uma ruptura, dividindo-o em homem e mulher, que se buscam eternamente e se completam.

Não é à toa, que desde a origem da propaganda com fins comerciais em 1852, é possível identificar a representação imagética de Cupido estampada nos mais diferentes suportes midiáticos, principalmente quando o relacionam a datas comemorativas promocionais como por exemplo campanhas para o Dia dos Namorados ou a comercialização de produtos ligados ao romance como alianças de casamento ou perfumes.
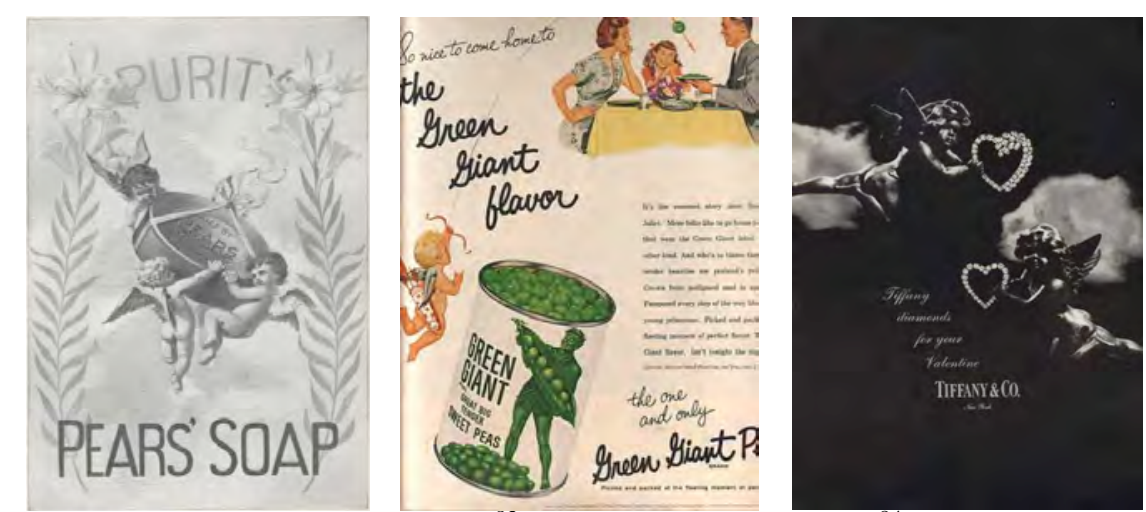

Figura 74: Anúncios com Cupido - Pear's Soap ${ }^{83}$ (1898), Green Giant Peas ${ }^{84}$ (1957) e Tiffany \& Co ${ }^{85}$ (1963)

\footnotetext{
${ }^{82}$ Pênia e Póros: Pênia está relacionada à penúria ou à falta de tudo, enquanto Póros possui ligação a expediente, ou seja aquele que resolve.

${ }^{83}$ Disponível em: <http://www.atticpaper.com/proddetail.php?prod=1898-pears-soap-ad-cherubs > Acesso:15/03/15

${ }^{84}$ Disponível em: <https://www.pinterest.com/pin/214484000974307258/> Acesso: 15/03/15
} 
Ainda analisando a figura do anjo esteticamente sendo retratada de forma infantil pela publicidade, podemos citar dois aspectos que exemplificam tal uso. O primeiro deles está na criação do logotipo utilizado durante anos pela marca italiana Fiorucci. Representada por dois anjos, um loiro e um moreno, que em muito lembram os anjos do quadro Madona Sistina de Rafael Sanzio, ambos também estavam constantemente alienados à cena da qual faziam parte, assim como a obra renascentista.
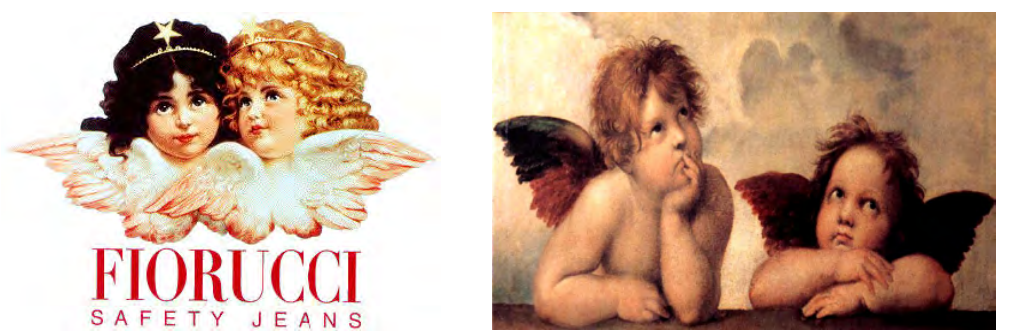

Figura 75: Logotipo da empresa Fiorucci e os anjos de Rafael de Sanzio presentes no quadro Madona Sistina

O segundo aspecto está relacionado ao anúncio criado e publicado em 1991 pelo fotógrafo Oliviero Toscani para a marca também italiana Benetton.

Ao retratar duas crianças abraçadas, uma negra de olhos escuros e uma branca de olhos claros, buscando representar a união de cores que a marca disseminava como proposta publicitária, Toscani subverteu a estética incomodando muita gente (entre eles o famoso publicitário brasileiro Francesc Petit da agência DPZ) ao buscar, de forma provocativa, captar as reações das pessoas.

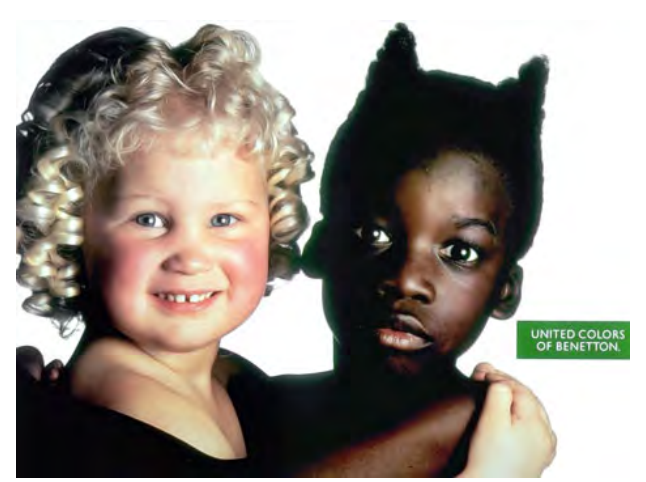

Figura 76: Anúncio "Angel and Demon" criado para a Benetton por Oliviero Toscani ${ }^{86}$

Isto porque, ao representar a criança branca de olhos claros, com cachos e a criança negra com dois coques no alto da cabeça, o fotografo gerou reações adversas ao

\footnotetext{
${ }^{85}$ Disponível em: <http://www.vintageadbrowser.com/jewelry-and-watches-ads-1960s/2/> Acesso: 15/03/15

${ }^{86}$ Disponível em:

<http://41.media.tumblr.com/b56a4e89cb09eda2f891055d10101c28/tumblr_mmcawjgHOy1s86b1ko1_500.jpg> Acesso em $15 / 03 / 15$
} 
anúncio, muitos o acusavam de preconceituoso e racista, criticando-lhe por atribuir "chifres" à criança negra e madeixas angelicais à criança branca, remetendo à lembrança do que conhecemos por anjo e demônio.

No entanto, devemos levar em conta que, ao empregar na publicidade aspectos provocativos como estes, seus criadores testam a compreensão do que e de quem os vê. Nesse sentido, um vasto repertório intelectual é de suma importância para que sejam analisados todos os aspectos estéticos que uma mesma peça pode proporcionar e até que ponto as crenças podem permear as vivências e os entendimentos das pessoas.

Nenhum desses anúncios citados até então parecem chocar ou gerar reflexões maiores quanto outros constantemente veiculados na mídia mundial.

Fazem parte destes últimos anúncios em que passa a ser determinado o sexo dos anjos e nos quais belíssimas mulheres de asas ganham contornos sensualizados para a venda de lingerie, adoção de cães ou divulgação de commodities como a água.

Anúncios como o criado para o cream cheese Philadelphia fabricado pela indústria alimentícia Kraft Foods, nos quais são facultadas aos anjos características femininas e masculinas, concedendo-lhes gênero, acabam por esteticamente modificar o conceito original do mito, atribuindo-lhe inclusive um clã familiar, como se este ser celestial pudesse procriar e conceber anjos, retirando por completo o aspecto assexuado que anteriormente o envolvia, dessacralizando-o.

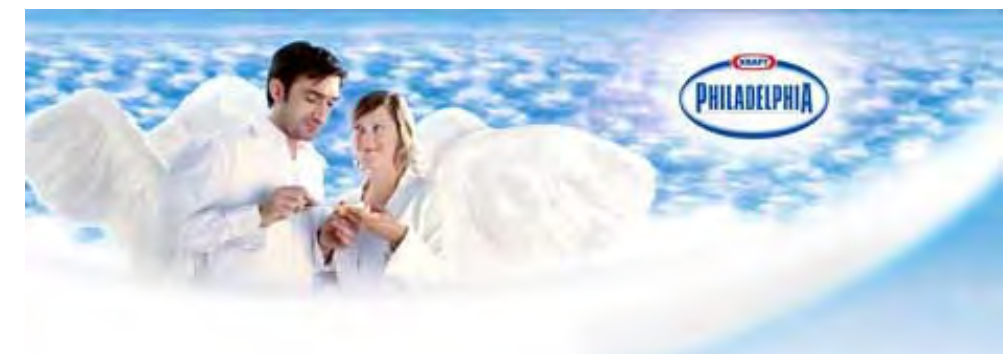

Figura 77: Anúncio para cream cheese Philadelphia - J. Walter Thompson - $1994^{87}$

A partir daí, podemos concluir que ao contrário dos anúncios do passado, quando a intenção ao utilizar a figura do anjo esteticamente em seu teor era a de transmitir a sensação de paz e tranquilidade ou fazer uma alusão à proteção como chancela do "divino", nos anúncios atuais e até mesmo àqueles que independente da época estiveram à frente de seu

\footnotetext{
${ }^{87}$ Disponível em: <http://theinspirationroom.com/daily/commercials/2005/9/Philadelphia-Heaven-De.jpg> Acesso em $15 / 03 / 15$
} 
tempo, mesmo sendo criativos, muitas vezes evidenciam câmbios estéticos extremos e radicais, buscando uma proximidade maior do comportamento humano, porém acabam também por agredir o imaginário até do mais desapegado espectador.

A partir da criação de anúncios que permitem incutir gêneros aos anjos, há uma evolução destes em relação à forma como se apresentam na publicidade e em que é possível notar uma fusão de arquétipos ao representá-los esteticamente.

Isto porque, ao inserir em anúncios anjos femininos, sensualizados, busca-se a mescla dos arquétipos da donzela e da femme fatale, em que ao unir a figura do anjo como pureza a uma mulher sensual, acaba-se por retratar estas donzelas, não mais apenas como modelos de pureza e inocência, mas também como fruto do desejo sexual masculino.

Para isso a figura do anjo feminilizada é comumente utilizada em campanhas de perfume como, por exemplo, a divulgação da fragrância Heavenly da marca americana Victoria Secret's.

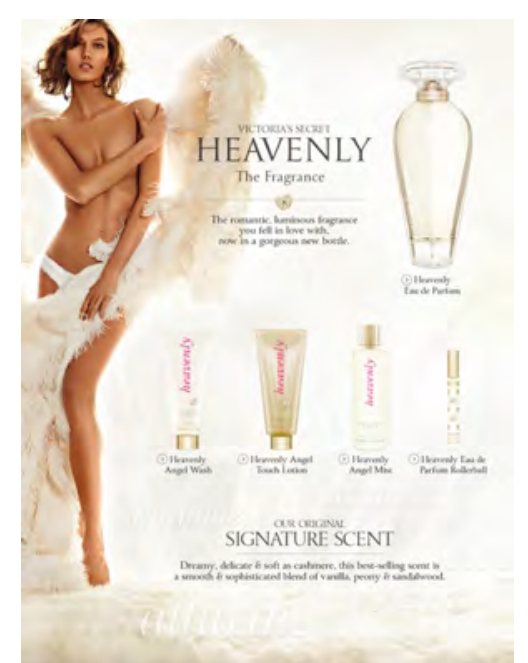

Figura 78: Anúncio para o perfume Heavenly - Victoria Secret's - $2014^{88}$

A representação sensualizada de uma anja-mulher também é utilizada como apelo publicitário, muitas vezes ao tentar vincular serviços à função do anjo como ser protetor. É o caso do anúncio veiculado em 2012 para o bar e boite de striptease Play Man, com o slogan "Sua noite tem salvação", no qual uma mulher de lingerie com penas brancas nas costas, que remotamente lembram asas de anjo, devido à qualidade e forma como representadas esteticamente na foto, busca transmitir a ideia de que ao frequentar o referido local, a noite

\footnotetext{
${ }^{88}$ Disponível em: <http://www.fashiongonerogue.com/karlie-kloss-wings-heavenly-fragrance-campaign/> Acesso em $15 / 03 / 15$
} 
não será perdida em função da presença de belíssimas mulheres que serão as responsáveis por entreter o leitor do anúncio.

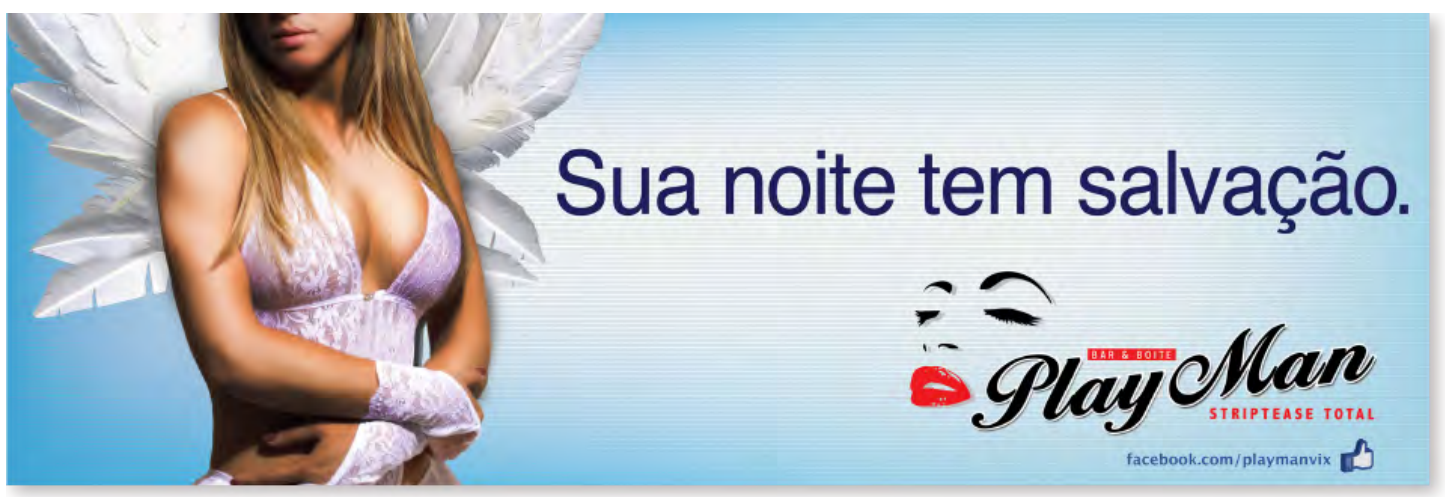

Figura 79: Anúncio para bar \& boite de striptease Play Man - Brasil - $2012^{89}$

No entanto vale aqui uma reflexão, visto que se utilizam deste mesmo conceito a organização não governamental PETA, com o intuito de promover a adoção de animais, bem como a empresa Evian, com o objetivo de comercializar água, nos fazendo questionar qual seria a necessidade de inserção da sensualidade nestes casos.

Este tipo de utilização estética em anúncios permite que o próprio leitor interpele sobre qual a necessidade da presença de uma seminudez feminina junto de um cão para a divulgação de adoção de animais ou por que a pureza da água que a Evian busca remeter em seu anúncio carece da presença de uma bela mulher negra seminua em cima de uma nuvem, visto que em detrimento da mensagem necessária faria pouca ou nenhuma diferença o fato destas figuras estarem completamente vestidas ou com uma bata branca, asas e auréolas, pois ainda assim representariam um anjo. 

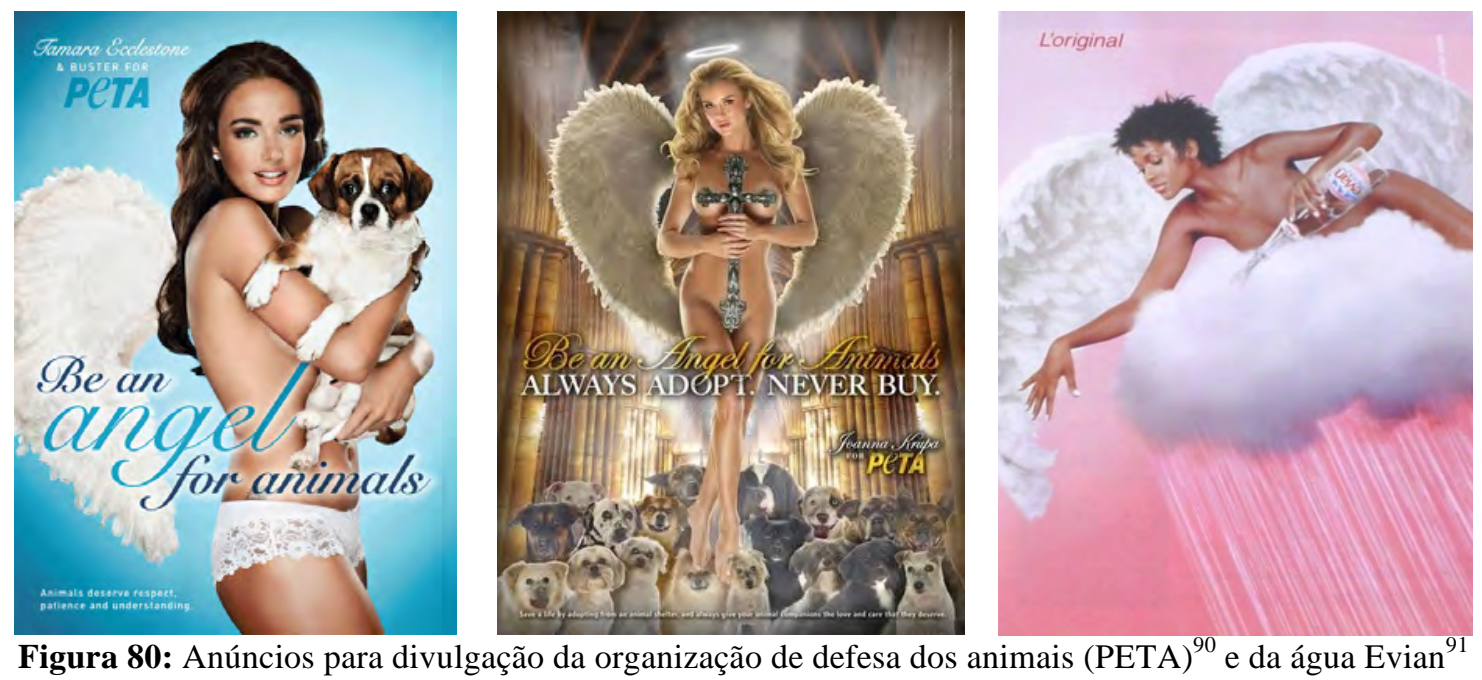

No entanto, não somente de mau gosto ou incongruências são dotados os anúncios atuais, nos quais constam a figura do anjo.

Alguns poucos acabam por dizer o necessário, mesmo utilizando-se da sensualidade, porém de maneira bem mais agradável, usando da sutileza, como é o caso do anúncio para o perfume Angel de Thierry Mugler, a campanha Got Milk? ou a publicidade dos bronzeadores Hawaiian Tropic, os quais apenas por meio de imagens, acabam por transmitir a noção de proteção através de asas completamente estilizadas.
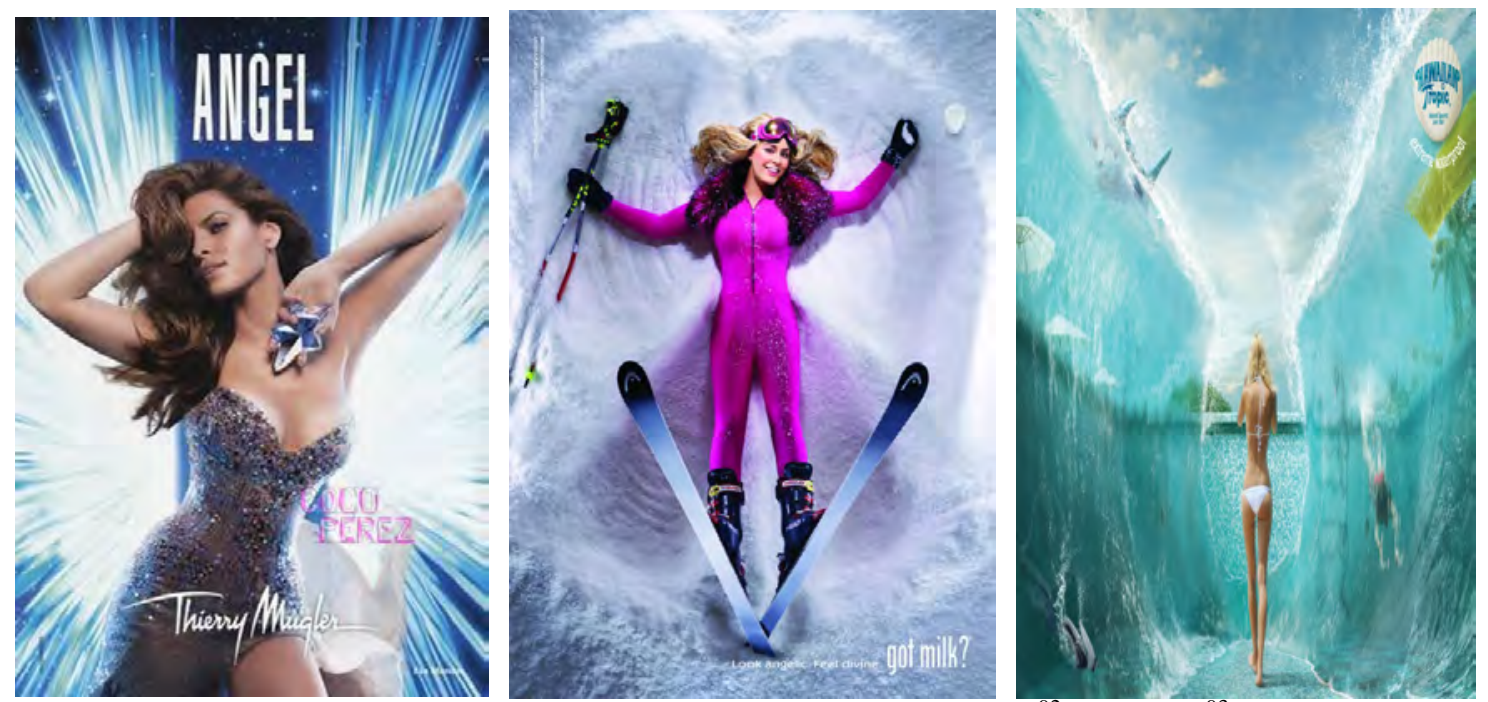

Figura 81: Anúncios da figura do anjo com asas estilizadas - perfume Angel ${ }^{92}$, Got Milk ${ }^{93}$ e Hawaiian Tropic $^{94}$

\footnotetext{
${ }^{90}$ Disponível em: <http://www.peta.org/wp-content/uploads/2013/10/AngelsSlideShow72NEW.GIF> Acesso em 15/03/15

${ }^{91}$ Disponível em: <http://designyoutrust.com/2012/07/pure-water-2/> Acesso em 15/03/15

${ }^{92}$ Disponível em: <http://www.theperfumegirl.com/perfumes/fragrances/thierry-mugler/angel-thierry-mugler/> Acesso em $15 / 03 / 15$

${ }_{93}$ Disponível em: <http://www.trendhunter.com/trends/lindsey-vonn-got-milk-ads> Acesso em 15/03/15

${ }^{94}$ Disponível em: <http://adsoftheworld.com/media/print/hawaiian_tropic_pool> Acesso em 15/03/15
} 
Todos estes câmbios estéticos da figura do anjo já citados aqui não contemplam estranheza ou incômodo como os que serão apresentados a seguir. Isso porque, ao modernizar a figura do anjo buscando acompanhar as mudanças de comportamento da sociedade contemporânea, a publicidade acaba por extrapolar limites impostos por esta mesma sociedade.

Ainda abordando o quesito sensualidade, gênero e dessacralização, podemos agregar mais um atributo a estas campanhas publicitárias atuais, o da profanação. A mais recente delas são os anúncios para celulares da Virgin Mobile, nos quais a figura do anjo é inserida em contextos sensualizados contendo em seu teor a divisão de gêneros como anjos masculinos, anjos femininos e anjos homossexuais, visando a captação e inclusão também do público gay como consumidor de seus produtos e serviços.

Porém, ao fazê-lo, extrapolam os limites do que a sociedade ainda considera convencional ao incluir em uma das versões de seus anúncios dois homens-anjos em situação romântica pecaminosa, não mais apenas dessacralizando a figura do anjo, como também profanando seu significado.
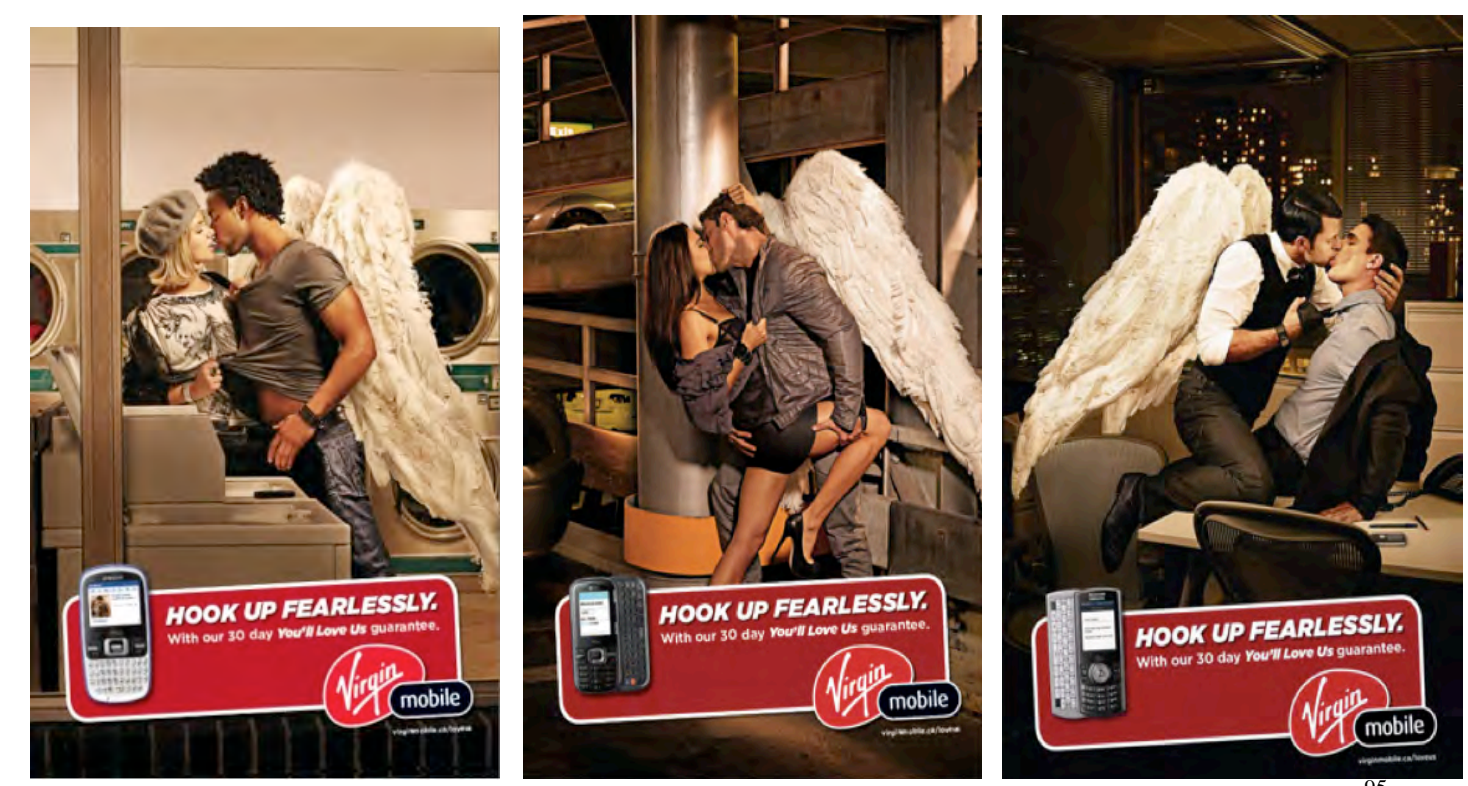

Figura 82: Anúncios polêmicos para comercialização de celulares da marca Virgin Mobile ${ }^{95}$.

Profanação e dessacralização foram aspectos que também podem ser apontados no anúncio criado em 2009, pela agência de publicidade J.W.Thompson, para o GAPA/BS, Grupo de Apoio à Prevenção à AIDS da Baixada Santista, visando o combate à AIDS.

\footnotetext{
${ }^{95}$ Disponível em: <http://www.marketingmag.ca/brands/virgin-fearless-ads-get-booted-from-transit-597> Acesso em $15 / 03 / 15$
} 


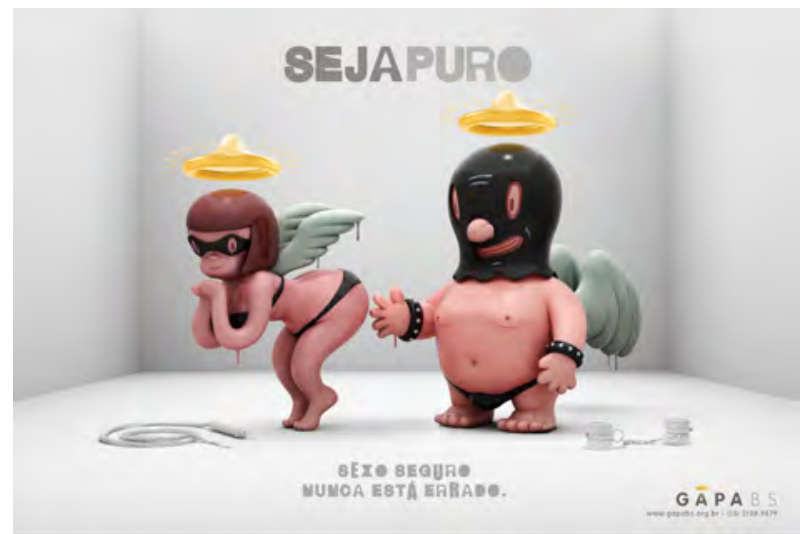

Figura 83: Anúncio para GAPA/BS visando o combate à Aids ${ }^{96}$

Representando esteticamente um "casal" de anjos, ou seja, atribuindo-lhes gênero e inserindo-os em um contexto sexualizado, visto que ambos surgem no anúncio trajando vestes e acessórios tais como couro, algemas e chicotes comumente utilizados por adeptos do sadomasoquismo ${ }^{97}$ e abaixo o slogan "Seja Puro. Sexo seguro nunca está errado", a instituição filantrópica buscou advertir e conscientizar sobre os riscos da AIDS.

Porém, ao buscar fazê-lo de maneira voltada para o humor, com o intuito de resgatar a pureza das pessoas, deixou claro também que o arquétipo do que vem a ser considerado pureza alterou-se com o passar dos anos em virtude do comportamento humano. Ou seja, o discurso adotado por este anúncio é de que atualmente manter-se puro é também manter-se sadio, utilizando para isso o preservativo. Contudo, com o intuito de divulgar os atributos de proteção e segurança neste caso, acabou-se por abolir qualquer santidade ou então espírito canônico da figura do anjo a ele atribuída, alterando-o esteticamente ao buscar representá-lo desta forma.

Apelo que mais tarde também seria utilizado com o mesmo intuito pelo sexshop Anjo Sado para a divulgação de seus serviços em veiculações realizadas em busdoor, no qual ao lado de duas mulheres em atitude sexual, um anjo nos moldes renascentistas veste máscara e empunha um chicote fazendo a divulgação do local através do slogan: "Sexshop Anjo Sado: não é tudo que você imagina...Mas é tudo que pode acontecer."

\footnotetext{
${ }^{96}$ Disponível em: <https://pipocavirtual.files.wordpress.com/2009/12/anuncio_anjos_-_by_gary_baseman.jpg> Acesso em $15 / 03 / 15$

${ }^{97}$ Sadomasoquismo: relação entre pessoas que buscam prazer sexual na dor.
} 


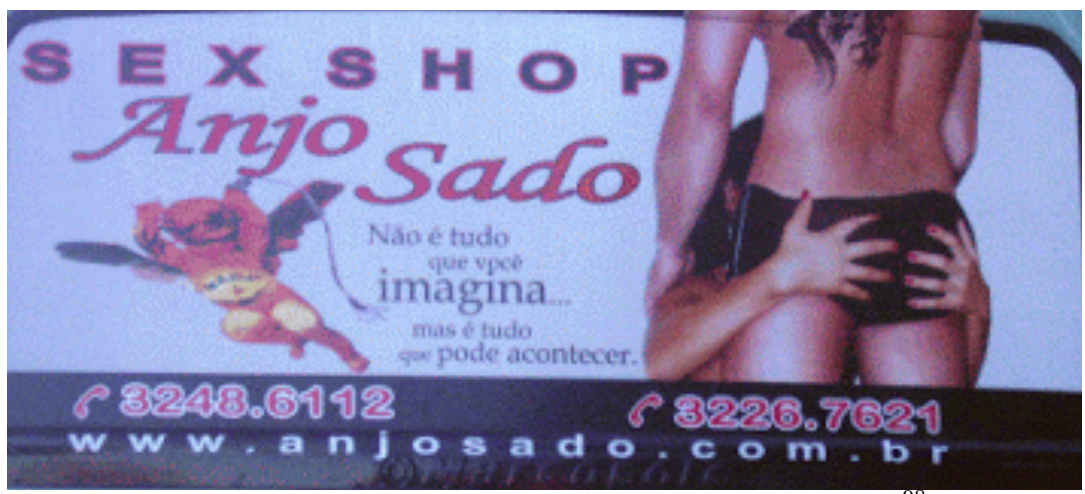

Figura 84: Anúncio para sexshop Anjo Sado em busdoor ${ }^{98}$

Por estar atrelada fortemente ao atributo proteção e segurança, a figura do anjo como já visto é amplamente usada em campanhas publicitárias. Em algumas delas, sua utilização é feita dentro dos parâmetros convencionais, porém, é possível encontrar anúncios e campanhas que buscam atingir seu público-alvo através de argumentações criativas e diferenciadas, utilizando-se para isso de estética ousada e provocativa.

A MTV Brasil, emissora cujo conteúdo é focado em música e voltado para o público jovem, busca sempre utilizar-se desses tipos de apelos menos tradicionais para captar a atenção dos telespectadores. Buscando incentivar o uso de camisinha para este target $^{99}$, a agência brasileira Loducca criou campanha publicitária em 2011 através de uma série de quatro anúncios impressos, nos quais a figura do anjo surgia dessacralizada e profanada ao ser estilizada como genitálias masculinas, portadoras de asas e auréolas, executando tarefas consideradas enfadonhas tais como tocar harpa, jogar xadrez, ler livros ou assistir à televisão, quando comparadas às relações sexuais.

Através da utilização do título e slogan "There is no sex in heaven. Stay alive. Use a Condom", ou seja, "Não há sexo no céu. Fique vivo. Use camisinha", a agência de publicidade propôs a utilização de um jogo de sentidos ao usar uma afirmação, embora na negativa, enriquecendo seu significado na frase seguinte ao pregar uma mensagem subentendida de "não morra, seja inteligente".

\footnotetext{
${ }^{98}$ Disponível em:

<http://1.bp.blogspot.com/_dWII6ZpYgh0/RpwMuNjC7EI/AAAAAAAAAyw/VLRuIxPHFdc/s400/sado.gif> Acesso em $15 / 03 / 15$

${ }^{99}$ Target: palavra em inglês cujo significado é alvo. Aplicada à publicidade, não necessariamente trata-se do público-alvo, mas sim dos objetivos que se visa atingir através das estratégias de comunicação.
} 

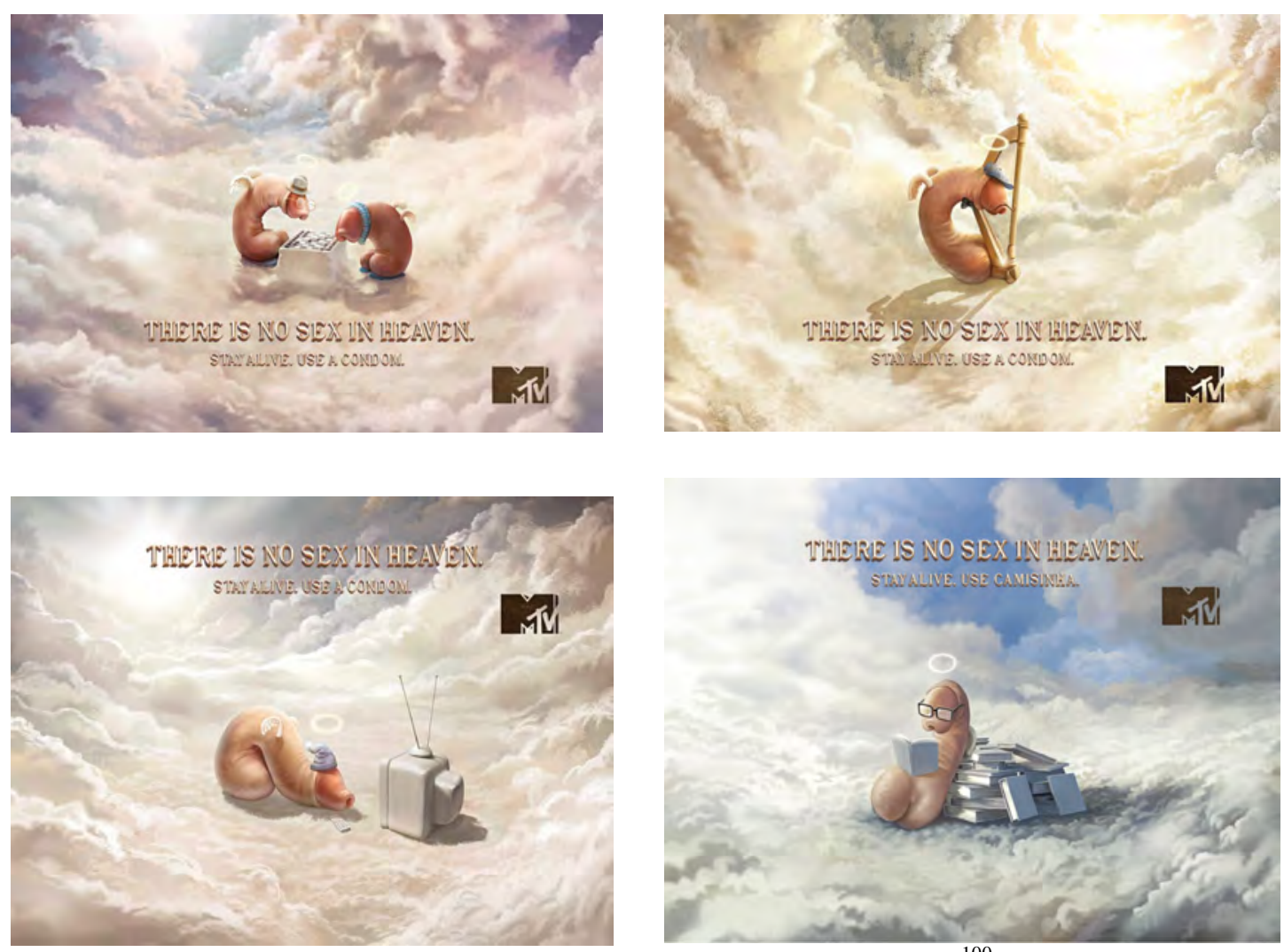

Figura 85: Anúncio para MTV Brasil - Brasil - 2012 100

\subsubsection{Os anjos, seus aspectos físicos e as características mundanas}

Como forma de aproximação junto ao público consumidor, outros câmbios estéticos vêm sendo utilizados com frequência pela publicidade, principalmente aqueles que atribuem à figura do anjo qualidades humanas, tais como alteração de aspectos físicos, execução de tarefas braçais, a presença de sentimentos negativos até mesmo hábitos não saudáveis.

Atualmente, deparamo-nos com anúncios como o utilizado para divulgação dos serviços da transportadora americana Xpress Movers, no qual em um ambiente celestial, são apresentados dois anjos com a estética mais convencional, ou seja, cabelos cacheados e aspecto infantil, carregando uma mobília e executando atribuições que deveriam ser realizadas por seres humanos, visto seu aspecto braçal. 
Abaixo, é possível ler um texto que diz "Let your furniture have the smoothest ride!", que, traduzido para o português significa "Deixe seus móveis terem um passeio mais suave!", o qual, apesar da utilização da estética considerada nada divina em função dos aspectos físicos que a peça propõe, busca ressaltar ainda assim a proteção e a segurança do serviço oferecido pela empresa.

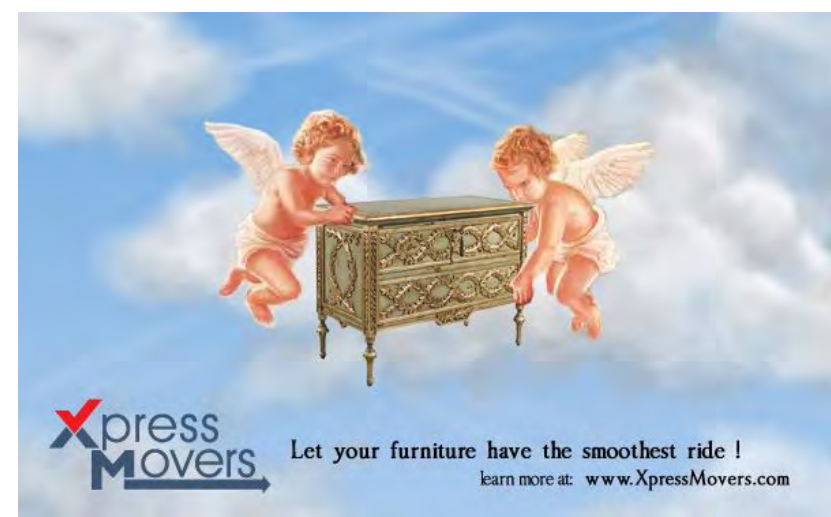

Figura 86: Anúncio da transportadora american Xpress Movers ${ }^{101}$

Outro exemplo de aplicação da figura do anjo em funções habitualmente executadas por seres humanos é o encontrado em anúncio criado em 2008, pela agência de publicidade americana Conill Advertising Los Angeles, para o sabão em pó Tide. Em uma série de três anúncios impressos, com anjos bem próximos da estética barroca, em função da desproporcionalidade de suas formas, os personagens são representados em um céu azulado esfregando roupas, remetendo à ideia de que levam para longe as manchas contidas nestas peças, buscando atribuir aos anjos o sentido de cuidado e proteção e transmitindo à marca o valor de lavar roupas como nenhuma outra o faz.
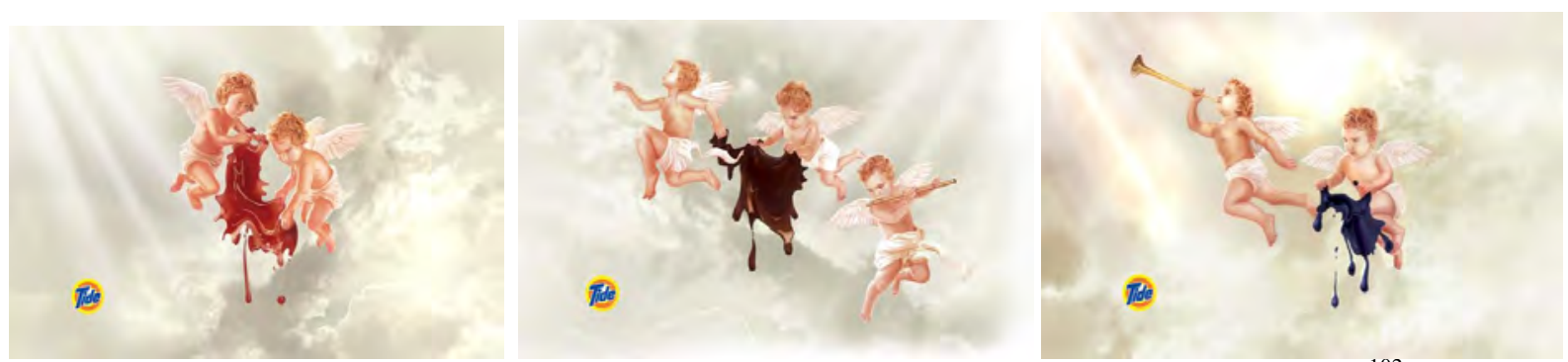

Figura 87: Anúncio para detergente Tide - Procter \& Gamble - Estados Unidos - $2008^{102}$

\footnotetext{
${ }^{101}$ Disponível em: <https://www.pinterest.com/pin/324611085613015584> Acesso em 15/03/15

${ }^{102}$ Disponível em: <http://www.coloribus.com/adsarchive/outdoor/tide-detergents-angels-11563305> Acesso em 15/03/15
} 
Torna-se possível encontrar tantas outras alusões a este mito moderno utilizando o comportamento humano na contemporaneidade. Muitos dos anúncios e campanhas chegam a beirar o mau gosto na estética representada como forma de chamar a atenção para a mensagem.

É o caso, por exemplo, de anúncio criado pela agência espanhola Grey Barcelona em 2009 para o inseticida Bloom, no qual um anjo jovem com aspecto andrógeno é esteticamente representado com várias picadas de inseto, algo inviável devido ao aspecto etéreo destes seres celestiais e através do título "Eternal life to mosquites", a empresa prega o fim dos insetos como se os enviando para o céu ao exterminá-los.

No entanto, ao redigir o texto desta forma, vale aqui uma reflexão pelo caráter dúbio que a peça busca atestar. Ao desejar vida eterna aos mosquitos, o contexto da peça e sua estética nos permitem afirmar que ao invés de exterminá-los, prega-se também sua permanência, inclusive perturbando anjos até então saudáveis.

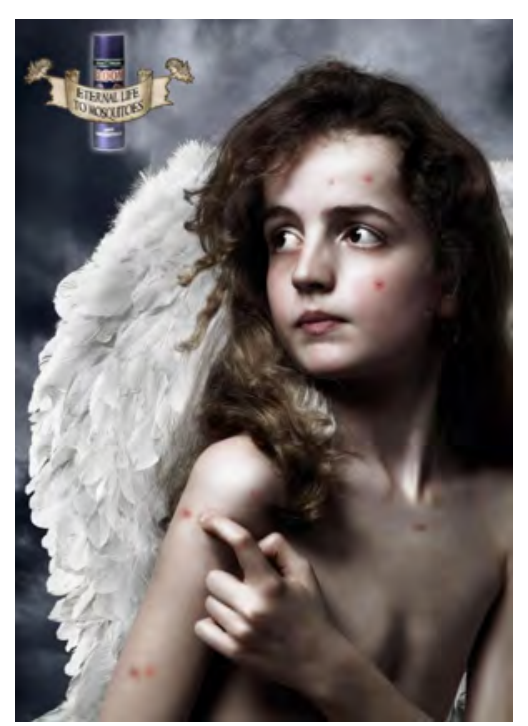

Figura 88: Anúncio contendo anjo com picadas de inseto criada para o Inseticida Bloom ${ }^{103}$

Ainda abordando o assunto, é possível encontrar também na publicidade a figura do anjo dessacralizada ao associá-la a insetos mortos por inseticidas como os anúncios para as marcas Baygon (2002) e Vapona (2009) ou anúncios de dedetizadoras que prometem exterminar ratos enviando-os ao céu, como é o caso da americana Truly Nolen (2006).

${ }^{103}$ Disponível em: <http://files1.coloribus.com/files/adsarchive/part_1324/13241305/file/bloom-insecticide-angel-small57719.jpg > Acesso em 15/03/15 

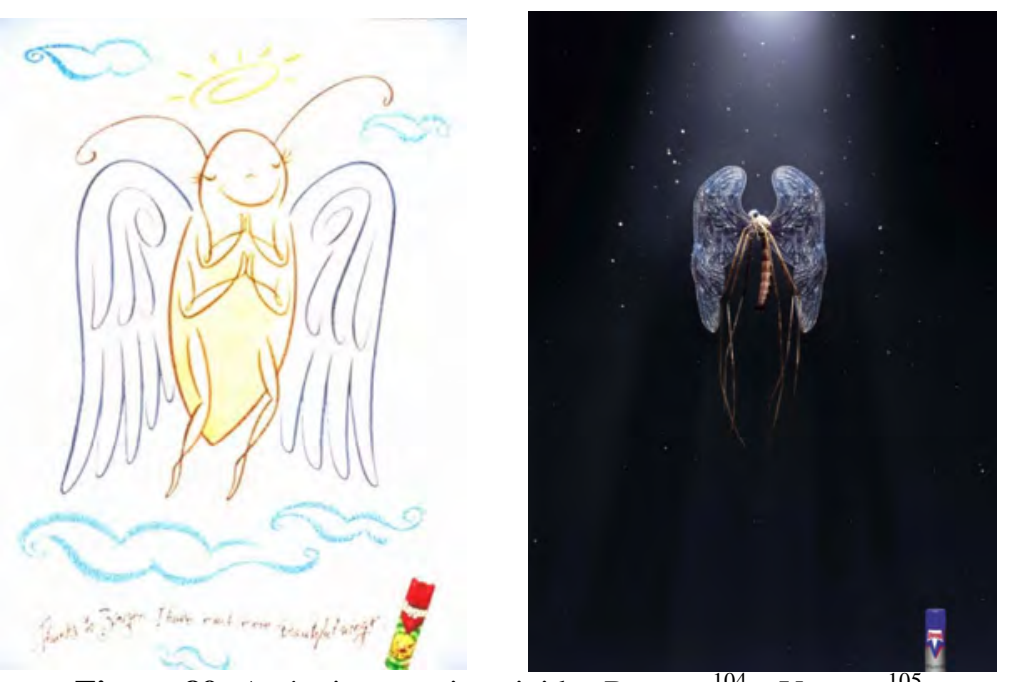

Figura 89: Anúncios para inseticidas Baygon ${ }^{104}$ e Vapona ${ }^{1}$

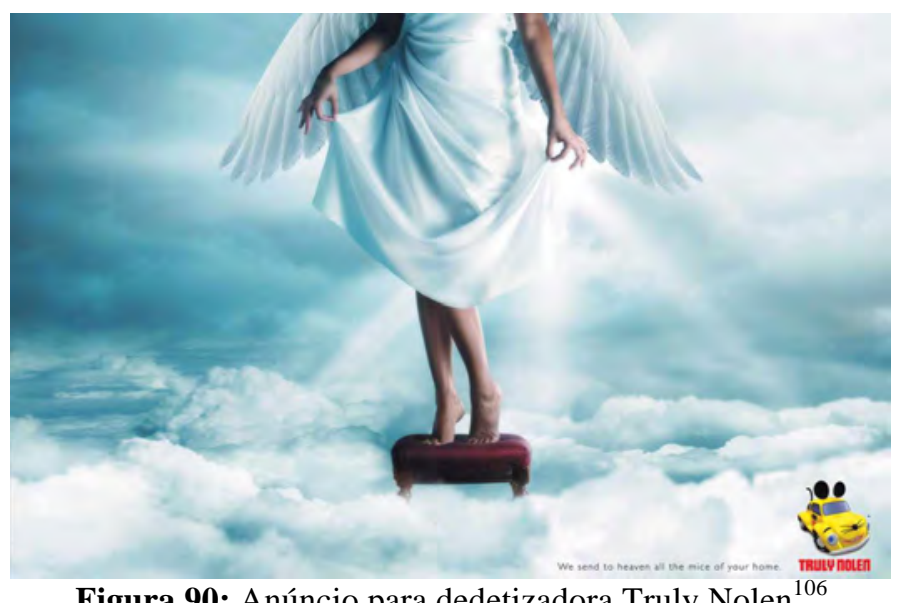

Figura 90: Anúncio para dedetizadora Truly Nolen ${ }^{106}$

Outro anúncio que busca aproximar o anjo através da atribuição estética de funções e atitudes humanas foi o criado pela agência Team/Y\&R da Romênia em 2003 para a fundação Save the Children International. Neste anúncio, sob a égide "For those who still believe smacking is righteous", ou seja, "Para aqueles que ainda acreditam que a palmada é algo justo" surge um anjo representado imageticamente com indícios de agressão física, visando prevenir o abuso infantil e incentivar a denúncia de possíveis casos.

A estética, neste caso, visa representar a criança como um anjo, devido à inocência e pureza que são dotadas, buscando deixar claro o absurdo que seria tal tipo de ocorrência, incitando todos a ficarem atentos aos acontecimentos próximos a suas redes de relações.

\footnotetext{
${ }^{104}$ Disponível em: <http://www.coloribus.com/adsarchive/prints/baygon-insect-repellent-angel-4066705/> Acesso em $15 / 03 / 15$

${ }^{105}$ Disponível em: <http://www.coloribus.com/adsarchive/prints/vapona-angel-13192305/> Acesso em 15/03/15

${ }^{106}$ Disponível em: <http://adsoftheworld.com/media/print/truly_nolen_angel> Acesso em 15/03/15
} 


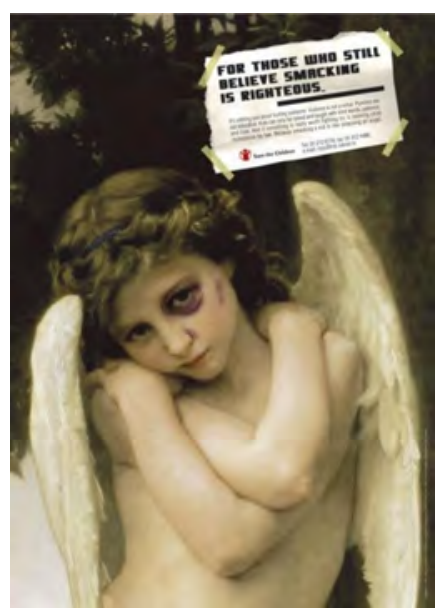

Figura 91: Anúncio para a ONG Save the Children ${ }^{107}$

Além de alterações estéticas da figura do anjo em anúncios publicitários, em relação a sua proximidade com o comportamento dos seres humanos, seja na realização de trabalhos braçais e aspectos físicos como as picadas de inseto ou agressão como exposto anteriormente, também são disponibilizadas outras formas de representação imagética do anjo com os mais variados fins.

Uma forma muito habitual utilizada por seguradoras dos mais variados patrimônios é a de ilustrar o anjo como dotado de características negativas humanas como preguiça, distração e cansaço, fazendo com que dessa forma, possa ser ressaltada a necessidade da aquisição de apólices como precaução, utilizando o apelo publicitário de que não basta apenas crer em um anjo da guarda, pois ele nem sempre estará alerta.

Nesta forma de anúncio, geralmente a apresentação estética do anjo também é alterada, figurando como um personagem desgrenhado, sonolento, distraído e desajeitado, para destacar ainda mais a conveniência na obtenção desses serviços.

Aspectos estes que ficam bastante evidenciados nas campanhas publicitárias da empresa Itaú Seguros realizadas pela agência de publicidade DM9 entre os anos de 2000 e 2001, no qual primeiramente um anjo masculino, trajando terno e gravata, de feições cansadas e com os pés dentro de uma bacia, ilustra o anúncio com os seguintes dizeres: "Anjo da guarda faz milagre. Mas não precisa abusar”, fazendo alusão ao cansaço físico, atributo humano que passa a transpor a realidade para o universo do anjo.

\footnotetext{
${ }^{107}$ Disponível em: <http://files1.coloribus.com/files/adsarchive/part_522/5225205/file/child-abuse-awareness-angel-small34783.jpg > Acesso em 15/03/15
} 

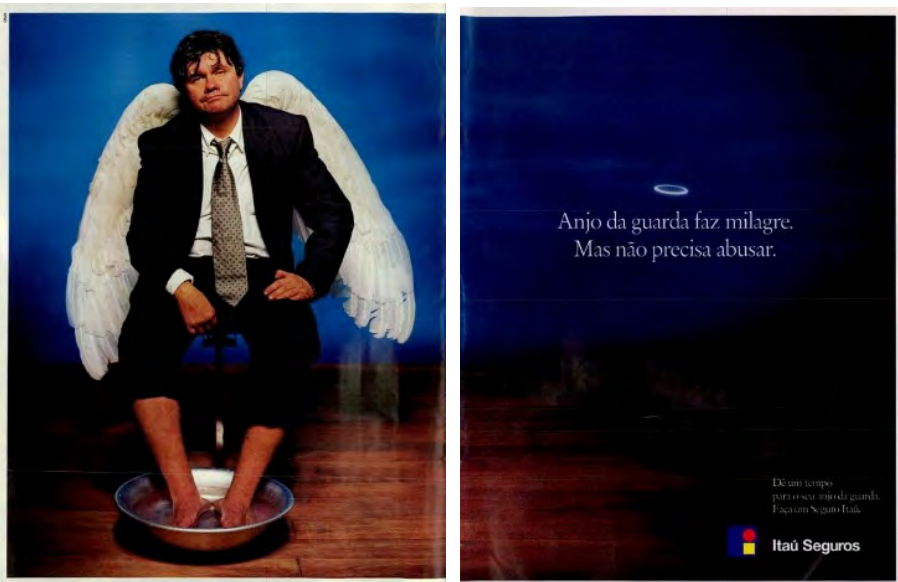

Figura 92: Anúncio para Itaú Seguros - 2000 108

Ou então, em uma segunda versão da campanha, também veiculada pela mesma agência no ano seguinte, demonstrando a figura do anjo em situações completamente mundanas, dormindo e com preguiça, quando na realidade deveria executar sua função primeira, a de proteção, ou então, retratado em situações que questionam sua capacidade de acolhimento em função imperícia, ou ainda considerando-o como capaz de submeter-se a prazeres luxuriosos, colocando-os adiante de qualquer outra necessidade, como por exemplo proteger alguém.
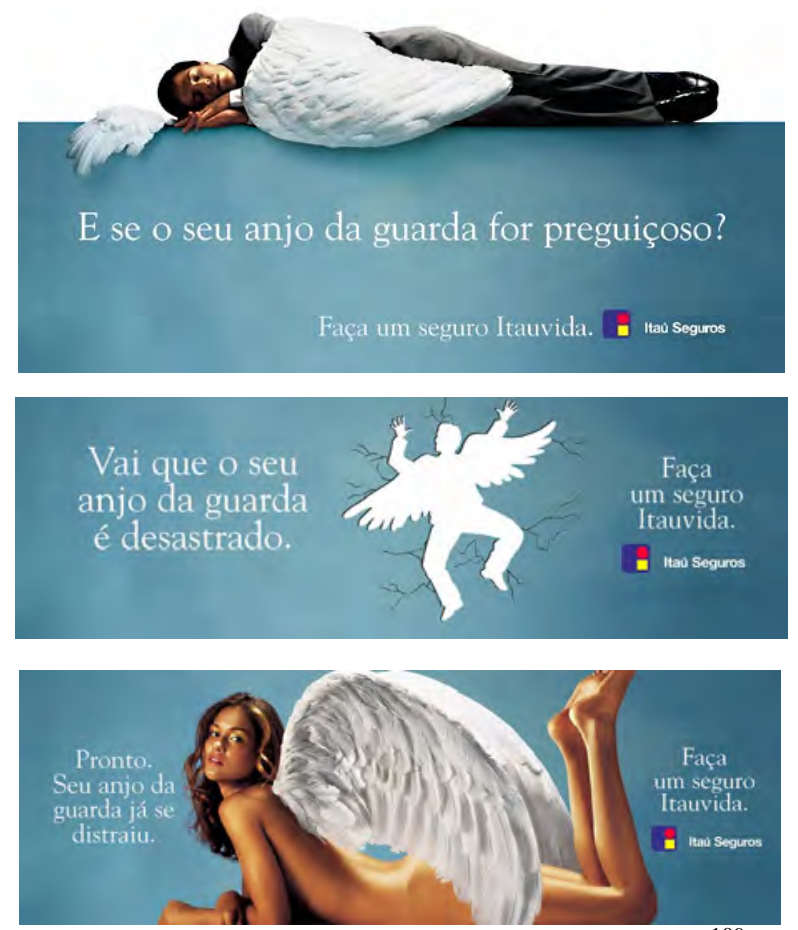

Figura 93: Anúncios para Itaú Seguros - $2001^{109}$

${ }^{108}$ Disponível em: <http://www.propagandaemrevista.com.br/anunciantes/por/I/?page=13> Acesso em 15/03/15 
O mesmo pode ser observado em anúncio divulgado pela Unimed ao ilustrar um anjo recostado em uma "poltrona" composta de nuvens como se este possuísse vida boa em função da existência dos serviços da empresa em questão, o que possibilitaria o descanso deste ser celestial.

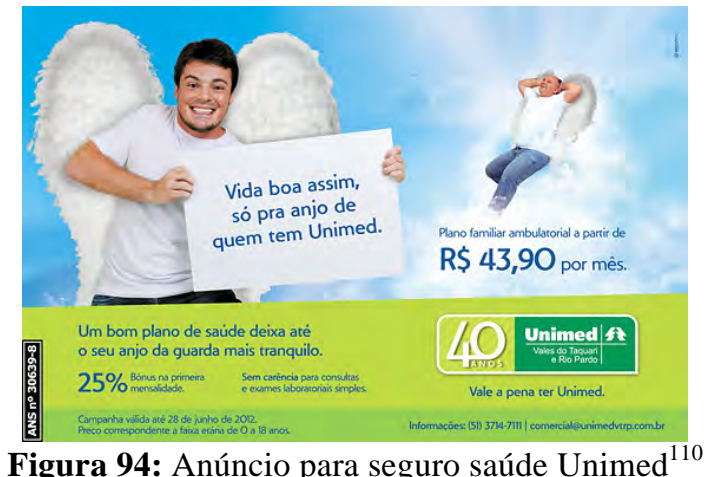

Porém, as empresas seguradoras também se utilizam da figura do anjo de outras maneiras em seus anúncios nem sempre ressaltando as asas, auréolas e a bata branca que constantemente evidenciam sua condição.

Em 2008, a agência Grey de Budapeste optou por utilizar outra forma de recurso para criar um anúncio destinado à divulgação da seguradora Allianz, visando a comercialização de serviços para condomínios. Nele, um homem de terno, com aspecto de executivo bem trajado e com cara de inteligente, posa diante de uma janela treliçada iluminada.

Os detalhes de tal imagem em um primeiro momento podem passar desapercebidos, visto que a janela treliçada, na verdade integra parte importante da composição da peça publicitária, pois ao ficar diante dela, a figura do anjo eclode ao permitir que o executivo "ganhe" um par de asas e auréola ao ficar diante da iluminação que surge por trás de seu corpo. O enunciado "It is taken care of" finaliza o anúncio com a informação "Isto está sendo cuidado", fazendo alusão novamente ao fator proteção, atributo muito comum e ligado à figura do anjo.

\footnotetext{
${ }^{109}$ Disponível em: <http://www.putasacada.com.br/anjo-da-guarda-para-itau-seguros-dm9ddb/> Acesso em 15/03/15

${ }^{110}$ Disponível em: <http://emporio.art.br/wordpress/wp-content/uploads/2012/05/anjos-jornal.jpg> Acesso em 15/03/15
} 


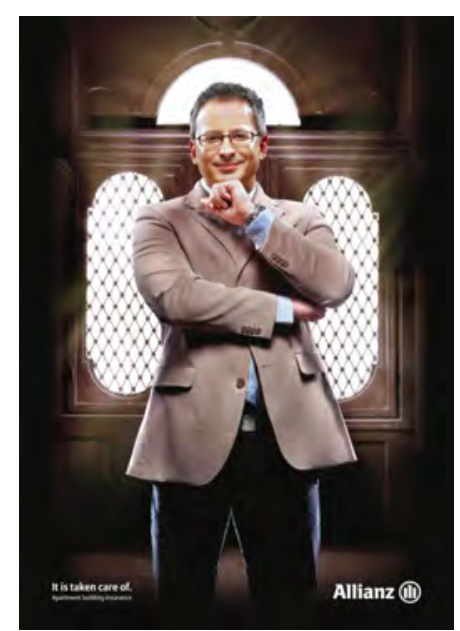

Figura 95: Anúncio para serviços financeiros da Allianz ${ }^{111}$

Ainda analisando as características estéticas inseridas em campanhas publicitárias, fazendo alusão às características físicas e aspectos mundanos utilizando a figura do anjo, podemos citar o anúncio criado para a BMW pela agência suíça DraftFCB Lowe Group em 2011, com o tema "Even angels give in to temptation. Heaven for sinner: bmw-roadshow.ch" que preconiza que até mesmo os anjos caem em tentação, incluindo em seu subtítulo um "endereço" de céu destinado a pecadores, neste caso, o website de vendas de motos da empresa.

Neste caso, o anjo é representado esteticamente através da luz que perpassa pela janela treliçada de um confessionário, onde do lado oposto há um motoqueiro no estilo “Hell's Angels” com olhar apreensivo. Na imagem, subentende-se que o anjo não é quem ouve a confissão, mas sim aquele que confessa seu pecado, o desejo por uma moto BMW, aproximando-o dos desejos mundanos e dos chamados pecados capitais como, por exemplo, a ganância.

\footnotetext{
${ }^{111}$ Disponível em: <http://www.coloribus.com/adsarchive/prints/financial-services-for-condominiums-guardian-angel$11223355 />$ Acesso em 15/03/15
} 


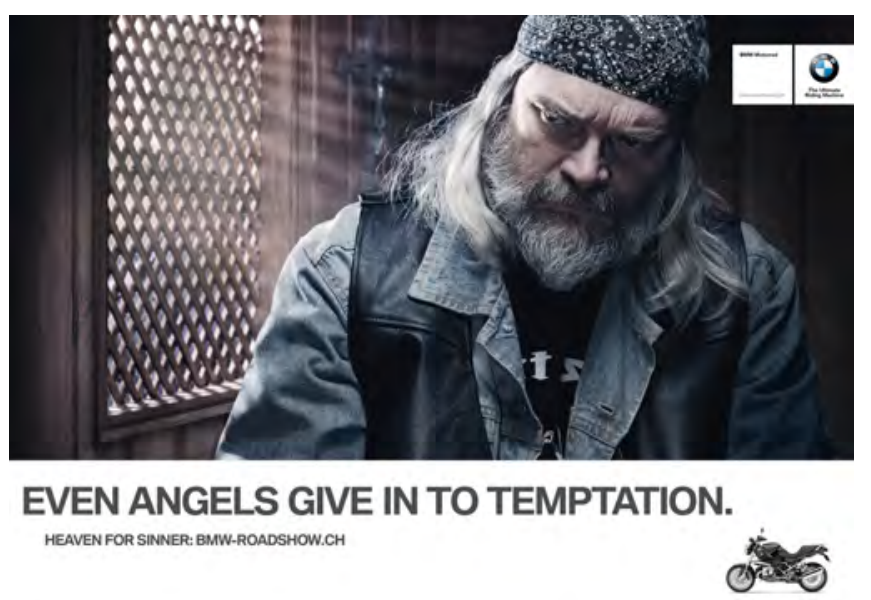

Figura 96: Anúncio da empresa automobilística BMW - Suíça - $2011^{112}$

É possível também encontrar outros anúncios que associam a figura do anjo aos pecados capitais e características mundanas, muitos deles comumente ligados à inveja.

Como por exemplo, o anúncio elaborado em 2001 pela agência argentina Scarpato para o portal de relacionamentos El Sitio, no qual um Cupido, representado neste anúncio com uma estética incomum, mais obeso, com pelos no peito e de língua de fora, demonstra toda sua inveja e revolta ao ver suas flechas do amor substituídas por um computador que fornece rapidamente cruzamentos entre os perfis dos usuários, permitindo relacionamentos sem a sua intervenção nesta era moderna.

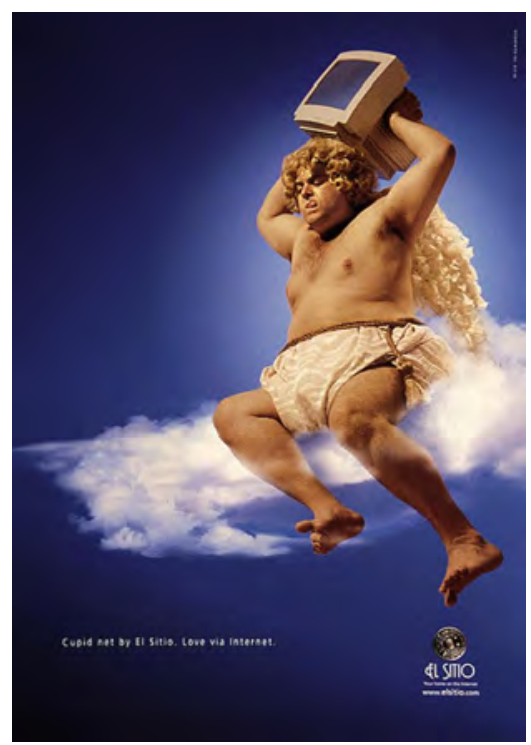

Figura 97: Anúncio para site de encontros amorosos El Sitio - Argentina - $2001^{113}$

\footnotetext{
${ }^{112}$ Disponível em: <http://adsoftheworld.com/media/print/bmw_motorrad_biker> Acesso em 15/03/15

${ }^{113}$ Disponível em: <http://www.coloribus.com/adsarchive/prints/elsitiocom-angel-3288205/> Acesso em 15/03/15
} 
Existem ainda representações da figura do anjo que saem do convencional quando analisado o aspecto físico com que este é reportado em algumas campanhas publicitárias. Dependendo da argumentação dada pelas agências de publicidade e o seu objetivo, anjos são transformados em seres obesos, acima do peso, para divulgar os mais diversos produtos e serviços.

Foi este o intuito da clínica de emagrecimento Marie France Bodyline, com filial na China, ao aprovar anúncio criado pela agência Cc\&e Guangzhou em 2011. Neste, um anjo feminino vestindo os trajes geralmente convencionados aos anjos, ou seja, as tradicionais asas brancas, auréolas e o vestido de cetim, fazem parte de todo o contexto.

Porém, reportam-na acima do peso, surgindo caída e desmaiada em um chão de cimento, em virtude de seu peso excessivo não lhe permitir mais voar. Isto visando ressaltar a necessidade dos serviços fornecidos pela empresa, tal apresentação estética no anúncio nos permite inferir que é preciso que um anjo esteja em forma, para que possa voar com a leveza necessária para proteção das pessoas.

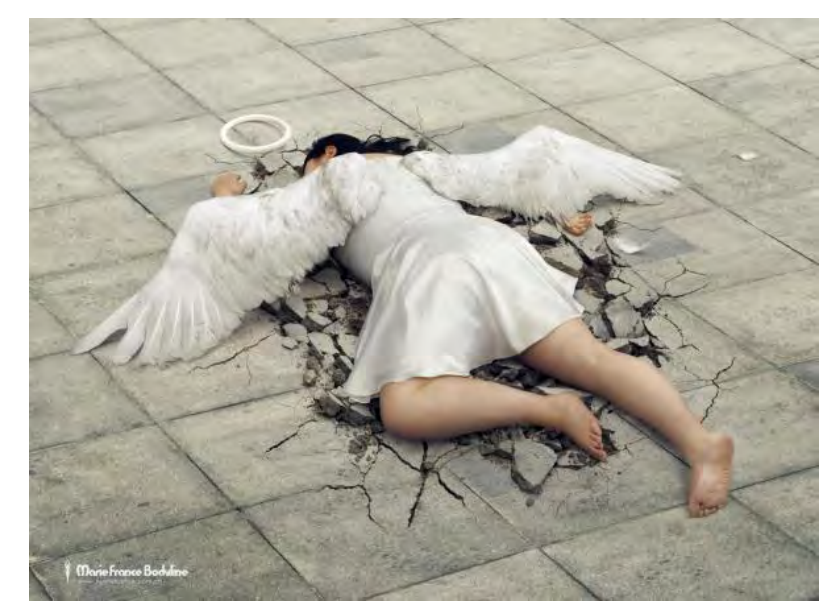

Figura 98: Anúncio para empresa de cosméticos e produtos de beleza Marie France Bodyline ${ }^{114}$

Outro anjo também reportado fora dos padrões estéticos ditados pela sociedade foi o criado em 2006 pela agência de publicidade Arc Worldwide para a empresa de cartões de crédito Capital One. No anúncio, um anjo masculino, ostenta um grande par de asas, camisa, camiseta e calça branca, barba por fazer e o cabelo desalinhado, além de estar acima do peso.

\footnotetext{
${ }^{114}$ Disponível em: <http://files2.coloribus.com/files/adsarchive/part_1595/15955005/file/beauty-slimming-angel-60035502.jpg/> Acesso em 15/03/15
} 


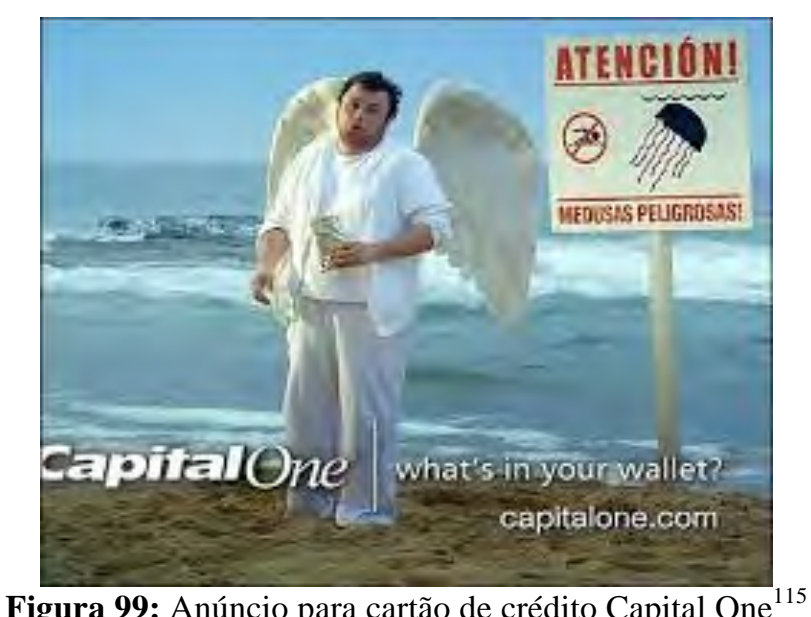

\subsubsection{Os anjos e as frases e expressões que os contemplam}

Não raro é também encontrarmos na publicidade expressões que liguem atributos positivos da figura do anjo à qualidade de produtos e serviços. Isto porque, por ser considerado pelas inúmeras religiões como um ser dotado de perfeição, acaba por municiar os criativos de agência com predicados que podem ser utilizados para convencimento do público-alvo que se deseja atingir.

No entanto, apesar de por vezes serem criadas peças publicitárias belíssimas, notamos que não há por parte dos criativos a mesma preocupação que há com a estética, isto porque muitas vezes são dadas conotações incorretas a um anúncio, justamente por não pensarem também na sua relação com a parte cognitiva, ou seja, a percepção que pode ser dada erroneamente a um determinado anúncio.

É o que notamos em campanha criada pela Ogilvy \& Mather Shangai em 2007, para o restaurante Gondola Veneziana e que foi vencedora do leão de bronze em Cannes no ano seguinte. Com fotos bem feitas e esteticamente aprimoradas, os anúncios da campanha, em um total de sete, reportam anjos infantis, tendo parte de seu cabelo tosado sem qualquer cuidado, deixando marcas expressivas no couro cabeludo destes.

Nos anúncios, tais anjos apresentam feições de choro, irritação e tristeza por tal fato, e ao final há a seguinte assinatura: "Freshly made angel hair", ou seja, "Cabelo de anjo

${ }^{115}$ Disponível em: <http://www.tvacres.com/enchanted_angels_capitalone.htm> Acesso em 15/03/15 
feito na hora", fazendo alusão a um tipo de macarrão existente na cozinha italiana. No entanto, permitimo-nos ponderar que misturar cabelo e comida, nem sempre é uma boa ideia, mesmo em anúncios criativos.

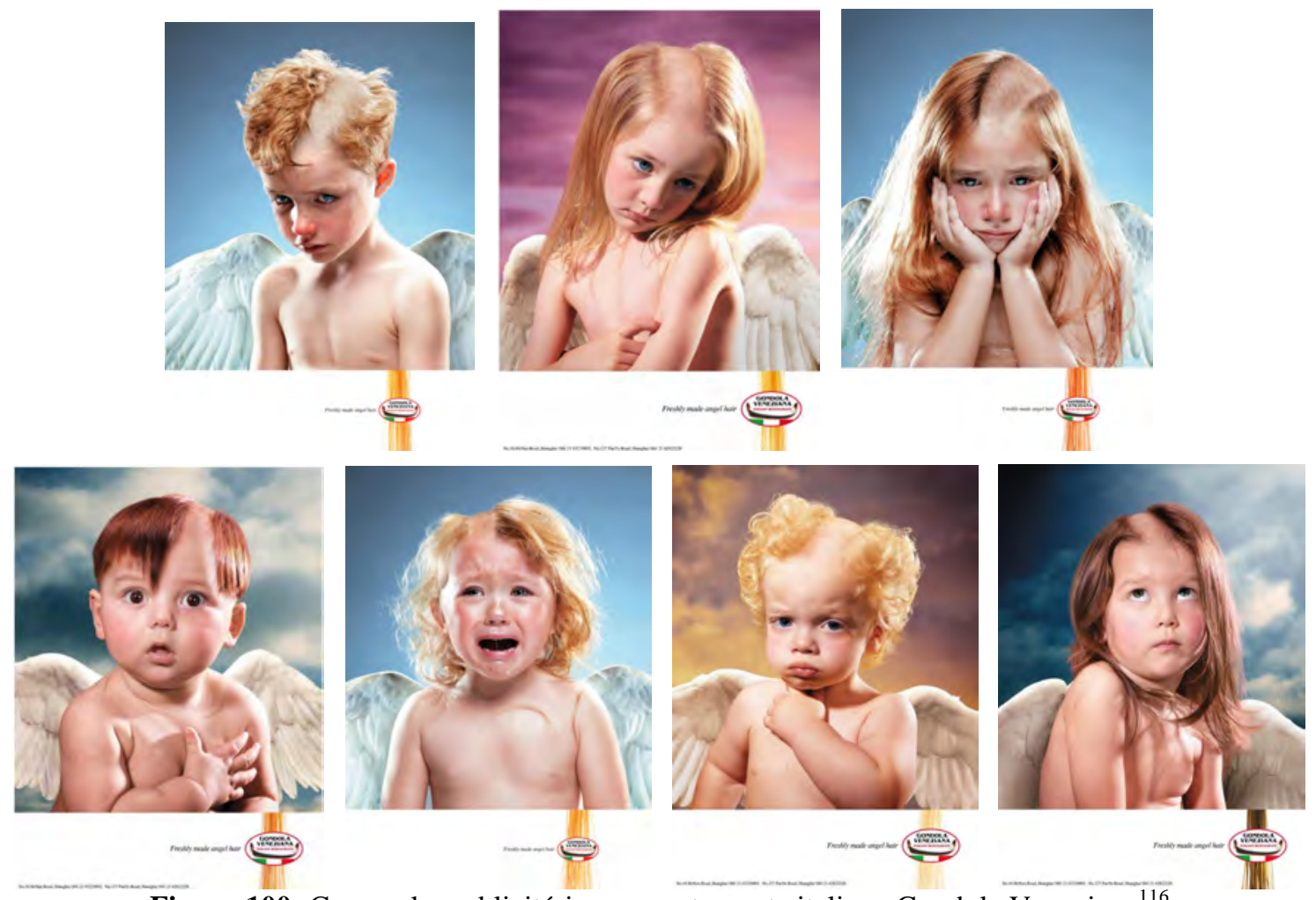

Figura 100: Campanha publicitária para restaurante italiano Gondola Veneziana ${ }^{116}$

Aproveitando-se da expressão "cabelo de anjo" e o fato destes seres celestiais serem constantemente ligados à perfeição, a filial sul-coreana da agência J.W.Thompson, criou em 2012 anúncio para divulgação dos produtos da marca Vidal Sassoon comercializados pela empresa Procter \& Gamble.

Em um céu dourado com nuvens ao fundo, seis anjinhos divertem-se voando e tocando instrumentos musicais. Esteticamente, todos são representados com os cabelos lisos e brilhantes e abaixo a assinatura preconiza: "It's time for the angels' hair to be beautiful. Vidal Sassoon, you will be remembered forever", informando as leitoras "É hora de ter cabelo de anjo para ser bonita. Vidal Sassoon, você será lembrada para sempre” . 


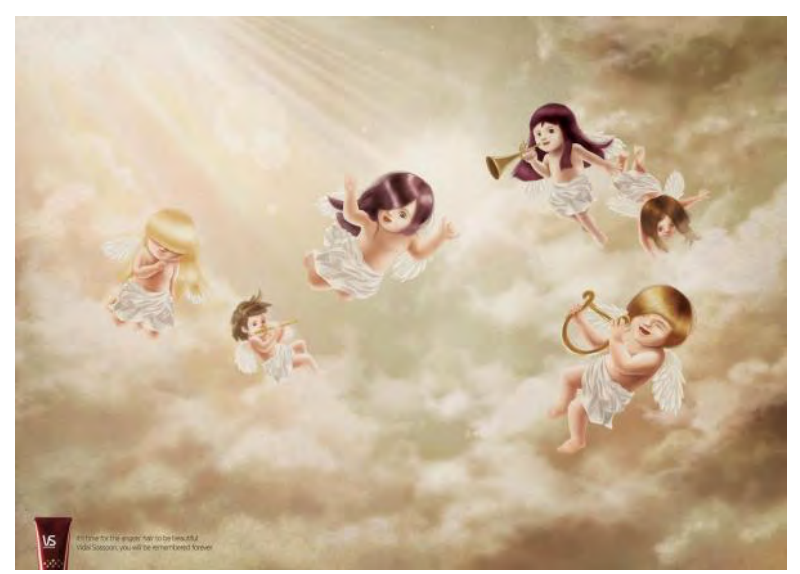

Figura 101: Anúncio para Procter \& Gamble - Vidal Sassoon ${ }^{117}$

Outra expressão encontrada em anúncios publicitários é a utilizada para designar o chamado "pé de anjo".

No passado, tal termo era usado para zombar de indivíduos que possuíssem pés avantajados, porém, hoje em dia, apesar da sua conotação permanecer inalterada, as pessoas não são mais ironizadas em função de sua condição.

Sabiamente, ao usar desse tipo de argumentação em anúncios publicitários para um público mais específico, os criativos o fazem de forma positiva, associando tal expressão à existência de empresas que criam produtos preocupadas em atrelar qualidade também para quem necessita de serviços sob medida.

Em anúncio criado para a empresa carioca de calçados de numeração grande Pé de Anjo, são inseridos pequenos elementos que remetem à figura do anjo, sendo eles a auréola estilizada como o pingo na letra “j” e o céu rosado com nuvens por trás da atriz Cacau Prado, usuária da marca.

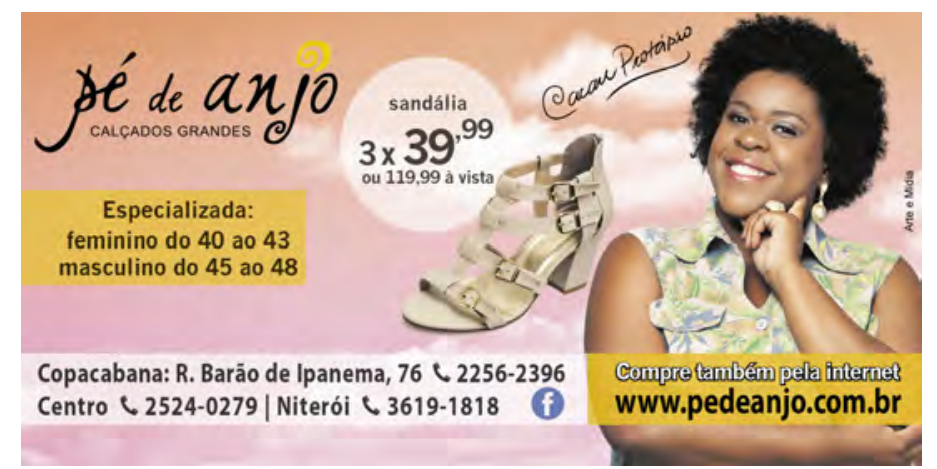

Figura 102: Anúncio para marca de calçados de numeração grande - Pé de anjo ${ }^{118}$

\footnotetext{
${ }^{117}$ Disponível em: < http://www.coloribus.com/adsarchive/prints/vidal-sassoon-hair-products-angels-hair-15425355/> Acesso em 15/03/15

${ }^{118}$ Disponível em: <http://arteemidia.com.br/wp-content/uploads/2014/11/OP_13564331_30-10-2014.jpg/> Acesso em 15/03/15
} 
Com a promessa de deixar suas consumidoras com "cara de anjo", a marca Neutrogena utilizou-se desta expressão cujo significado remete a um rosto belo, para vender a máscara facial City Angels em anúncio criado pela agência UniversalMcCann para a Johnson \& Johnson na China.

No anúncio, a figura do anjo é representada pela presença de uma jovem chinesa sorrindo com um rosto impecavelmente liso e limpo. Em suas costas surgem asas estilizadas, como se ao utilizar o produto, este lhe transformasse em um desses seres celestiais.

Além disso, a expressão "cara de anjo" fica subentendida na peça publicitária pelos resultados demonstrados através do anúncio, no qual a pele da modelo não demonstra nenhuma erupção ou vermelhidão, além de transmitir muita jovialidade.

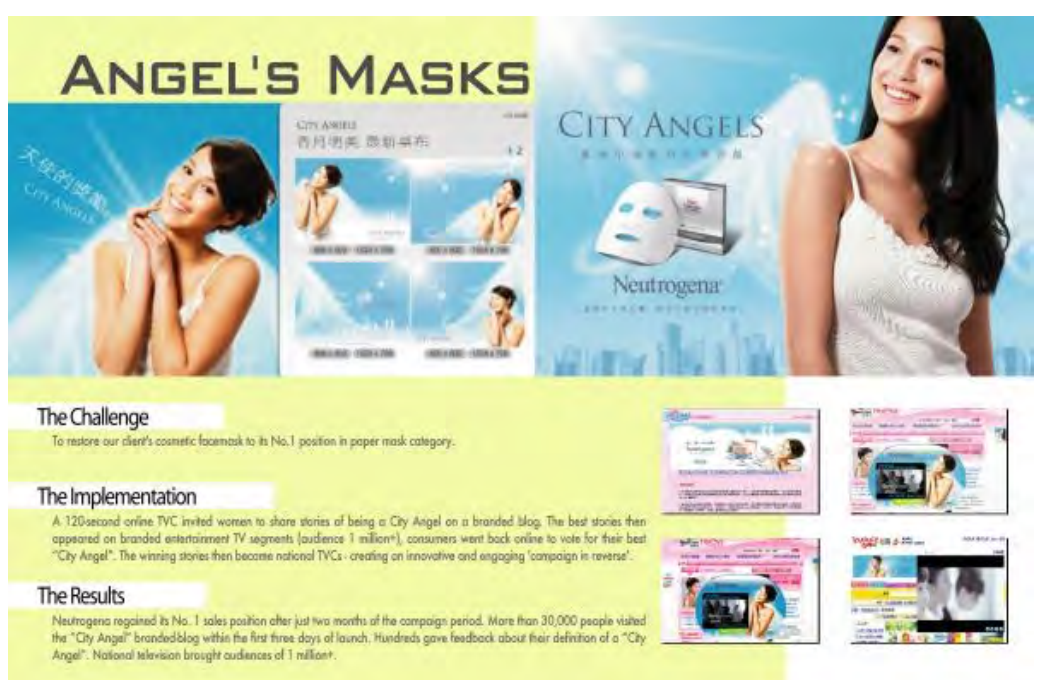

Figura 103: Anúncio para máscara facial Neutrogena - China - $2006^{119}$

\subsubsection{Os anjos e suas características adversas ou antagônicas}

Durante séculos, a humanidade buscou na figura dos anjos o que estes seres celestiais sempre simbolizaram: proteção, cuidado e conforto. No entanto, com o passar dos anos, acabaram tão mergulhados e inseridos cada vez mais nos comportamentos da sociedade,

\footnotetext{
${ }^{119}$ Disponível em: <http://www.coloribus.com/adsarchive/prints/neutrogena-face-mask-angels-mask-8348205/> Acesso em 15/03/15
} 
que permitiram torná-los o mais fiel reflexo "humano" do ser, inclusive no seu lado mais mundano, sombrio e proibido.

Hoje, mais próximos da contemporaneidade quando sua representação midiática possui expressividade acentuada e mais realista, podemos afirmar que a figura do anjo foi transmutando-se no decorrer do tempo, firmando características bem específicas de acordo com sua época de pertencimento.

O pensamento humano, em todas as épocas e culturas, vem evoluindo desde o mais simples até o mais complexo raciocínio abstrato ou simbólico, permitindo a convivência com as diferenças de raça, cultura, religião, línguas ou modo de ser e agir.

Desde o seu surgimento, o Homem tem sido movido por duas lógicas, uma consciente e outra inconsciente, em que a passividade e o instinto acabaram sendo revestidos pela razão e a consciência. Tal afirmação pode basear-se no que Sigmund Freud denominou como princípios da psicanálise opostos que acabam digladiando-se, sendo um deles os princípios do gozo e prazer e o outro a realidade, relacionando-os com o que conhecemos por desejo e cultura.

O contraponto entre a cultura e o desejo sempre constituiu um jogo de forças, em que a cultura buscou administrar, compreender e resolver o que pregava o desejo, no entanto, costumeiramente utilizou-se da repressão, da imposição de regras e da punição para que pudesse conviver com as dissonâncias impostas pelo desejo, como a existência do erótico, do tabu e de diferentes formas de expressar a sexualidade.

Partindo desta teoria do contraponto, todas as culturas ainda possuem dificuldade na aceitação do que vem a ser o Bem e o Mal e como estão eles relacionados com a constituição dos seres humanos.

Conscientes disso, os publicitários passaram a utilizar em anúncios com a figura do anjo uma visão advinda do pensamento maniqueísta ${ }^{120}$, na qual através de uma maneira “ $a$ priori" simplista de pensar dividem o mundo em bem e mal, o que pode ser compreendido como uma boa ferramenta de argumentação para a propaganda, porém tal simplificação na forma de pensar nasce oriunda da falta de repertório, do desconhecimento em relação ao que o outro julga ser verdadeiro e a tudo que se apresenta como mais complexo.

Ao utilizar-se do maniqueísmo em campanhas e anúncios, esta maneira simplista e dogmática de pensar, a publicidade acaba por utilizá-lo para personificar ideias. No entanto,

\footnotetext{
${ }^{120}$ Maniqueísmo: filosofia religiosa sincrética e dualística fundada e propagada por Mani, filósofo cristão do século III, que divide em dois princípios opostos o Bem e o Mal, encarando-as como entidades antagônicas e onde a luz e as trevas não são meras figuras retóricas, mas sim representações concretas do Bem e do Mal, que encontram-se em permanente conflito.
} 
se partirmos do pressuposto do que sugere Nietzsche, em sua obra "Zur Genealogie der Moral", ao refletirmos para além do bem e do mal: "Perguntai aos escravos quem é o "mau"? e apontarão a personagem que para a moral aristocrática é "bom", isto é, o poderoso, o dominador" (GM, pref. XI), acaba por nos fazer compreender que a concepção do que é bom ou mau, dependem de quem julga e de quais são os interesses envolvidos.

Um anúncio que pode exemplificar bem o já exposto foi o criado em 2009 pela agência americana Anton \& Partners, para a marca Givenchy, visando a divulgação do perfume “Ange Ou Démon".

Na campanha divulgada em televisão e mídia impressa e estrelada por Uma Thurman, percebemos uma contaminação da forma, em que através do jogo de luz e sombra, e da utilização de cores como o branco e o preto, acabam por criar um contraponto entre o bem e o mal, ou melhor, duas mulheres em uma, constituindo em uma mesma forma a junção de duas figuras.

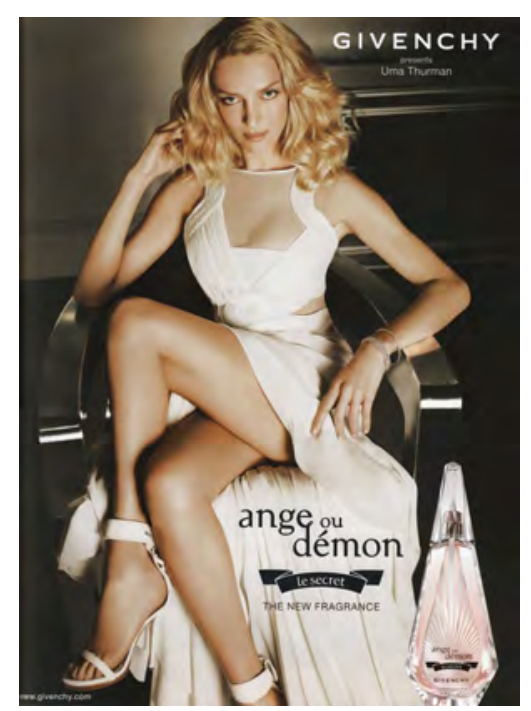

Figura 104: Anúncio do perfume Ange ou Démon da Givenchy estrelado por Uma Thurman ${ }^{121}$

Isto porque, ao utilizar-se da cor branca em anúncios, a publicidade a associa geralmente à bondade, inocência, pureza e à luz, conferindo-lhe um caráter de perfeição e por ser constituída através do equilíbrio entre todas as cores, acaba por angariar atributos como igualdade, imparcialidade, justiça e neutralidade. Já a utilização do preto, comumente

${ }^{121}$ Disponível em: <http://models.com/work/givenchy-ange-ou-demon-fragrance-fw-2009/> Acesso em 15/03/15 
associado à elegância, à maldade e ao poder, acaba relacionando-se ao escuro, ao medo e ao desconhecido, dando a campanha um ar de mistério e de tudo que é oculto e secreto.

Ao inserir no anúncio, luz e sombra, branco e preto e Uma Thurman de cabelos loiros e em vestido branco que poderia remeter a uma bata como vestimenta, não fosse o decote, a transparência e o salto alto que acabaram por conferir-lhe sensualidade, buscou-se aplicar justamente na campanha publicitária o que o nome da fragrância da Givenchy prega: seria ela um anjo ou demônio?

Na junção de figuras tão antagônicas, notamos o atravessamento, ou seja, o outro lado do anjo, a utilização de cores permite demonstrar tal deslocamento e sua ligação com a contemporaneidade e o comportamento humano, em que as oposições são marcas expressivas de nossa cultura, sintetizando e trazendo tudo isso para um mesmo parâmetro publicitário.

$\mathrm{Na}$ ânsia por obter campanhas de sucesso, muitas vezes as agências de publicidade, ao trabalharem com contrapontos ou antagonismos, acabam esbarrando na má compreensão e entendimento das mensagens que desejam passar.

Este é o caso da campanha criada em 2011 pela BBH de Londres e com produção da MJZ, sob a assinatura "Even Angels will fall" ou "Até os anjos cairão", com adaptação brasileira realizada pela BorghiErh/Lowe para o desodorante masculino Axe Excite.

Trata-se de um anúncio metafórico no qual os anjos destinam-se a representar algo maior do que simplesmente belas mulheres. Nele, a argumentação é que o desodorante Axe é tão irresistível que até mesmo os anjos serão atraídos por ele.
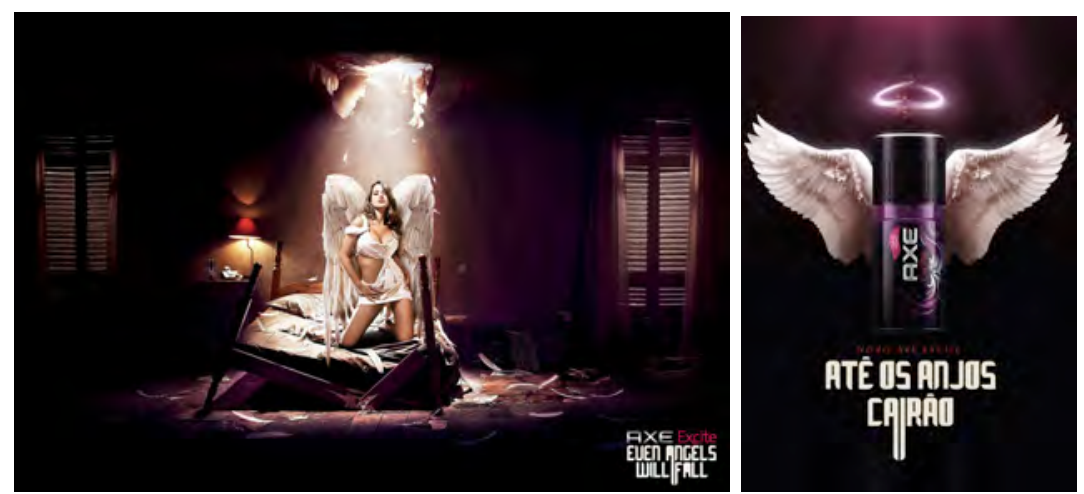

Figura 105: Anúncio para desodorante masculino Axe Excite - Porto Rico - $2011^{122}$

O contraponto neste caso está justamente no fato de um anjo feminino sensualizado ter "caído" não deixando claro se este permanece como anjo bom que foi tentado pela luxúria de um homem que usa desodorante Axe Excite, mas que a qualquer momento

${ }^{122}$ Disponível em: <http://adsoftheworld.com/media/print/axe_angels_1/> Acesso em 15/03/15 
pode retornar ao céu, ou trata-se de um anjo pecador, que assim como Lúcifer caiu e permanecerá na terra devido aos seus desejos mundanos.

A campanha toda é pautada em belos anjos femininos em vestes e posições sensuais, porém com suas asas intactas. Esteticamente, no entanto, o que nos dá indícios sobre sua tentação são a ausência da auréola ou então a colocação desta em local nada convencional, como por exemplo no colo ou entre as mãos.
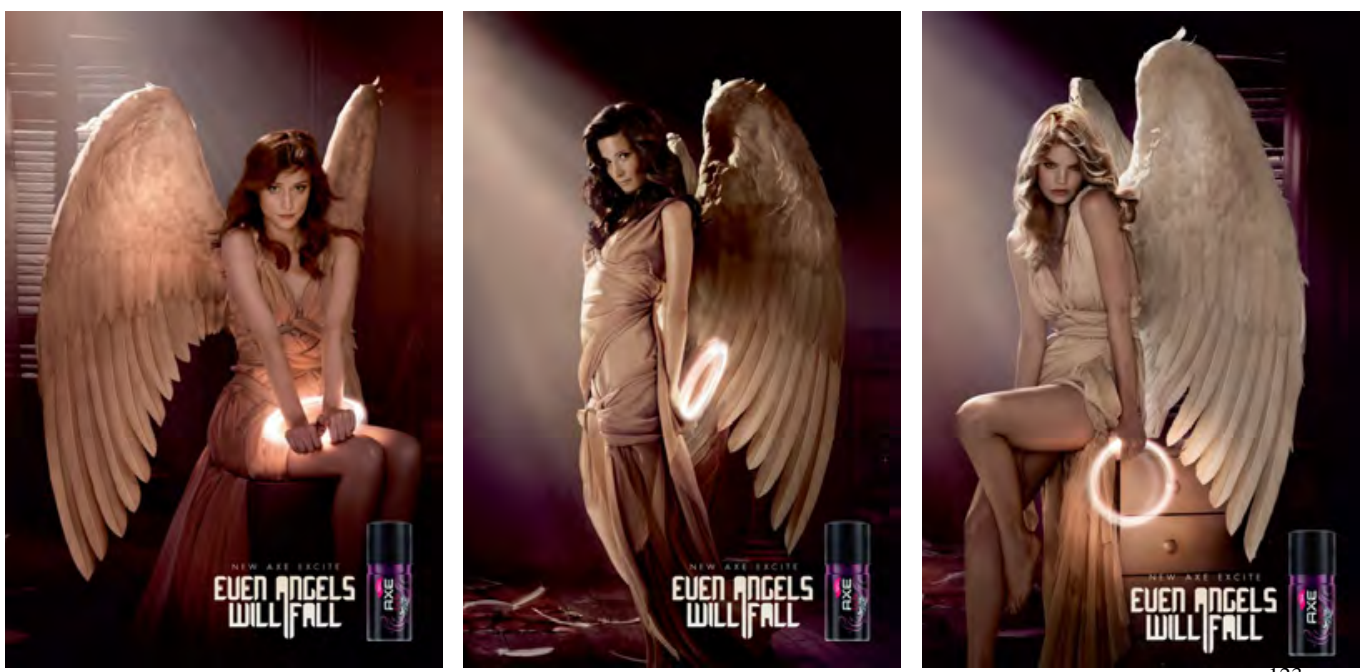

Figura 106: Anúncios para desodorante masculino Axe Excite - "Até os anjos cairão"123

Ao utilizarem o termo anjo caído no anúncio publicitário, estão associando a figura do anjo à perda de sua força, que resultaria em um encontro sexual implícito iniciado por este ser celestial quando entrou em contato com um homem irresistível por utilizar o desodorante corporal Axe. No entanto, anjos caídos são aqueles geralmente rebeldes e contrários a Deus e por essa razão banidos do céu, o que nestas peças publicitárias não fica claro, visto o caráter dúbio que transmitem.

Mesmo o mais atento espectador não consegue discernir se a figura do anjo irá de fato desistir de seu estado celeste e cair nas graças de um homem, renunciando ao seu estado celestial em detrimento de desejos mortais, pois a mensagem pretendida não é clara, apenas o seu objetivo final, que os homens adquiram produtos tentados pela ideia de serem sexualmente irresistíveis para as mulheres.

Ao levar adiante a ideia da utilização da figura do anjo nos anúncios utilizando para tanto um personagem construído culturalmente e considerado símbolo de inocência, santidade e pureza, o resultado não poderia ser outro que não a hipérbole, ao afirmar que o

${ }^{123}$ Disponível em: <http://br.adforum.com/creative-work/ad/player/34462240/> Acesso em 15/03/15 
uso do desodorante Axe fará com que seus usuários sejam tão sexualmente atraentes que nem mesmo os anjos serão capazes de resistir à tentação.

Diversos outros anúncios usam deste mesmo contexto para fins publicitários no qual o apelo é demonstrar que até o mais sacro dos anjos pode cair em tentação, seja pelo desejo carnal a uma mulher, seja pela tentação de prazeres mundanos como a bebida alcóolica.

Como é o caso da loja de roupas Diesel, que busca demonstrar atitude e posicionamento da marca através de anúncios minimalistas.

Neste caso, através da mesma utilização das cores preto e branco e suas significações, dois anjos masculinos de longas asas disputam a atenção de uma bela mulher esteticamente retratada de negro representando o pecado e o proibido.

Ao disputá-la em uma briga, demonstram despreocupadamente a intenção de pecar, entregando-se a luxúria pecaminosa de um envolvimento amoroso, indo às vias de fato para realizá-lo.

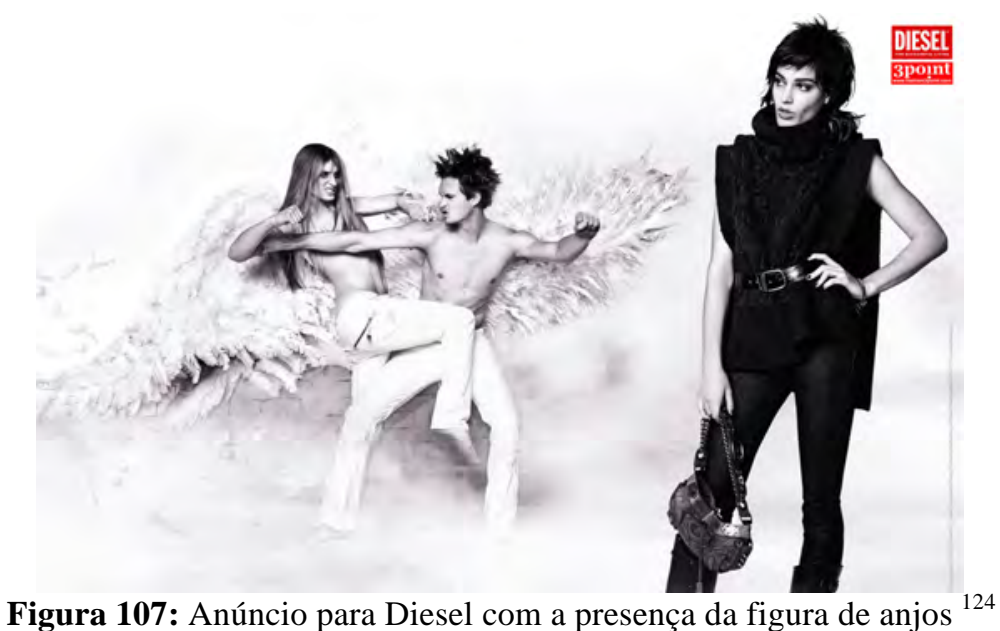

A indústria de bebida alcóolica também busca atribuir a transgressão como apelo em seus anúncios publicitários. Para isso, por vezes associa a tentação como forte argumento em suas peças de divulgação. Apresentando-se como irresistíveis, as marcas de bebida vêm no simbolismo de utilizar a figura do diabo tentando um anjo, robusta justificativa para captar novos consumidores. Prova disso, são os vários anúncios em que encontramos com este tipo de alegação, tais como os da Vodka SKYY, Martini e Ballantine’s.

${ }^{124}$ Disponível em: <http://www.desktopwallpaperhd.net/view/diesel-clothes-fight-angel-118017.html /> Acesso em 15/03/15 

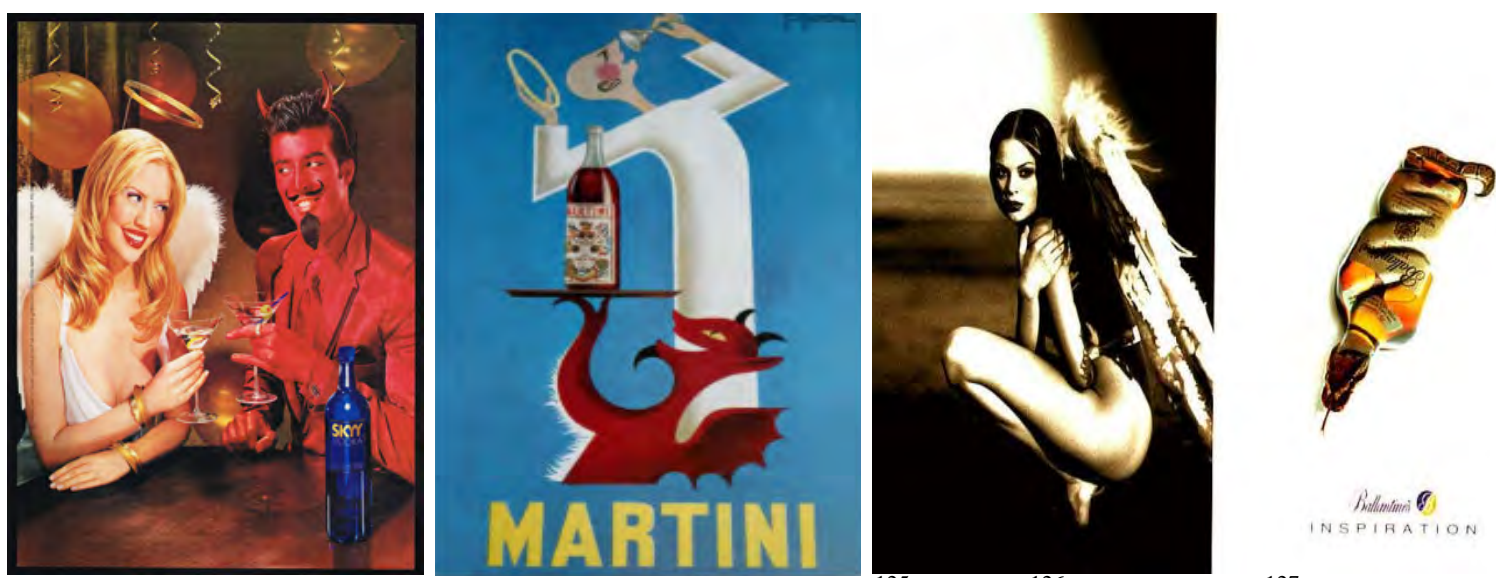

Figura 108: Anúncios para Vodka SKYY ${ }^{125}$, Martini ${ }^{126}$ e Ballantine's ${ }^{127}$

Assim como os anúncios analisados anteriormente, a Pirelli também fez uso da teoria do contraponto, utilizando-se das figuras do anjo e do diabo para divulgação do pneu Angel ST.

Em um anúncio de página dupla, a empresa de pneus divulga seu produto através de uma representação estética de um homem loiro de cabelos cacheados e de pele alva, com um feixe de luz sob sua cabeça. Devido a essas características, leva o leitor a crer que se trata de um anjo, mesmo não sendo visíveis suas asas. Com a camisa aberta, apresenta em seu peito a existência de um demônio aprisionado em uma jaula. Ao final, o título do anúncio informa "Angel ST. The first tyre with a double soul" transmitindo a mensagem "Angel ST. O primeiro pneu com alma dupla".

Tais características estéticas se devem a dois fatores: o primeiro deles demonstra que o pneu Angel ST é resultado de soluções tecnológicas inovadoras e por essa razão permite mesclar suas funções desportivas às exigências de segurança e confiabilidade, portanto unindo duas atribuições em um mesmo produto; e em segundo uma parceria firmada entre a Pirelli e a Sony Pictures para atividades de comunicação do filme Anjos e Demônios, em que pneus da marca foram fornecidos para utilização em muitas cenas.

Ao demonstrar a dualidade na peça publicitária, o que a marca deseja é apropriar-se do ditado popular "rosto de anjo e coração de demônio" que reportando para o produto em questão seria o mesmo que afirmar que este possui além do belo design, desempenho relevante.

\footnotetext{
${ }^{125}$ Disponível em: <http://www.ebay.com/itm/2002-Devil-Angel-Old-Friends-Skyy-Vodka-Print-Ad-/350873072707/> Acesso em 15/03/15

${ }^{126}$ Disponível em: <https://s-media-cache-ak0.pinimg.com/736x/68/7f/cd/687fcd6497681313abb1fd4bf241b899.jpg/> Acesso em 15/03/15

${ }_{127}$ Disponível em: <http://www.coloribus.com/adsarchive/prints/ballantines-whisky-angel-1308805//> Acesso em 15/03/15
} 


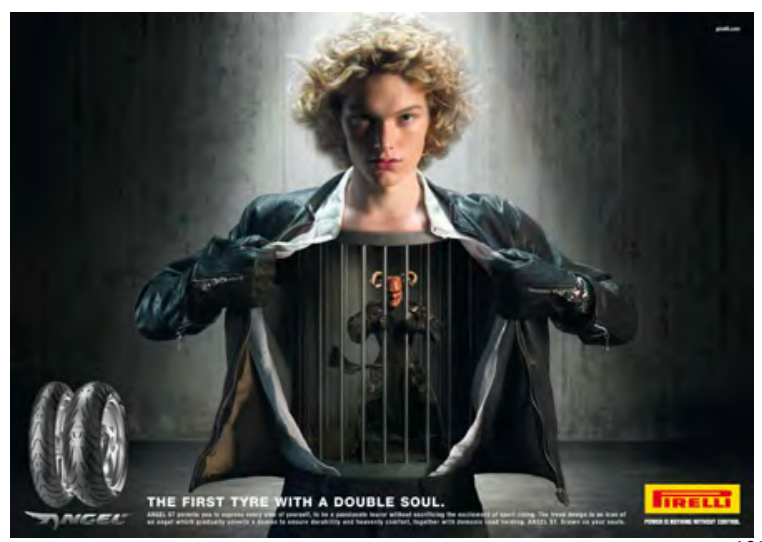

Figura 109: Anúncio para pneus Angel ST da Pirelli ${ }^{128}$

Utilizando-se do mesmo apelo, ou seja, a união de duas figuras contrastantes em uma só, podemos mencionar o anúncio desenvolvido em 2011 pela BBH London para documentário exibido pela ITV.

Nesta peça publicitária em um fundo preto, grandes asas brancas estilizadas envolvem uma sombra com chifres que remetem à figura do diabo integrando o interior de um anjo. Como as duas figuras juntas compõem uma única com o slogan "Is it wrong to do good in a bad way?" ou seja, "É errado fazer o bem em um mau caminho ?” torna-se impossível desassociá-las.

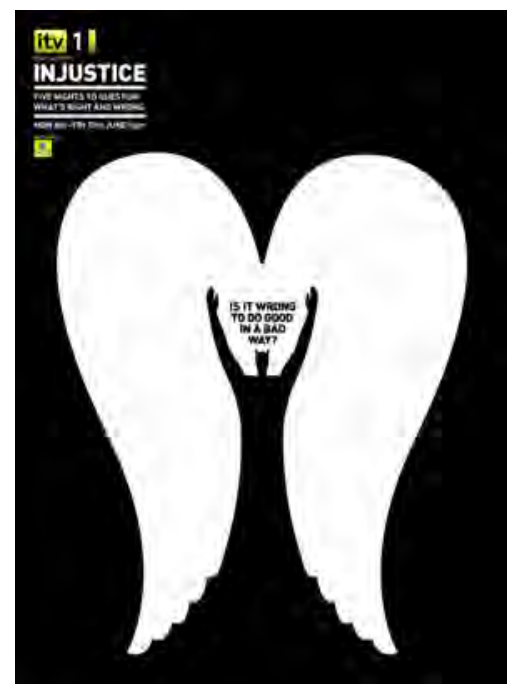

Figura 110: Anúncio para documentário na ITV Injustice - Inglaterra - $2011^{129}$

\footnotetext{
${ }^{128}$ Disponível em: <http://photos.imageevent.com/motorbiker/newspics3/Ad-Pirelli-Angel-Italy.jpg> Acesso em: 15/03/15

${ }^{129}$ Disponível em: <http://adsoftheworld.com/media/print/itv_injustice_angel> Acesso em: 15/03/15
} 
Outra forma de utilização do anjo em anúncios publicitários é o antagonismo, sem a junção do bem e do mal na mesma figura, porém permitindo a interação das expressões na mesma peça publicitária.

É o que podemos notar em anúncio criado para o corretivo Paper Mate intitulado "Right the wrong", elaborado pela agência TBWA de Kuala Lampur em 2013, ganhador de vários prêmios entre eles Clio Awards e Cannes.

Em um fundo completamente branco, no canto direito superior encontra-se o slogan "Corrigir o erro" em tipologia cursiva, um anjo feminino todo branco com as asas abertas, representando aqui o produto, surge montado sobre um diabo todo negro dominando-o com os dedos sobre sua testa para desta forma fazer jus ao que a frase prega.

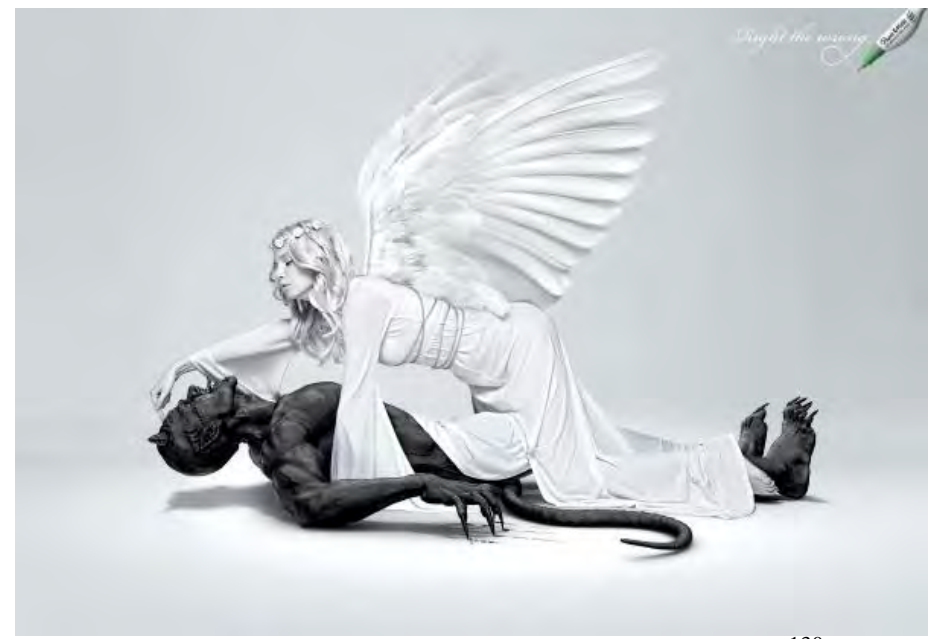

Figura 111: Anúncio para corretivo Paper Mate ${ }^{130}$

O anúncio impresso da Paper Mate, ao utilizar tal frase, demonstra o anjo, ou seja, o bem dominando e conquistando o diabo, o mal. Assume assim uma postura dramática ao tratar uma caneta corretiva como poderosa força do bem para aniquilar o mal. Habilmente criativo, o produto acaba por personificar a figura do anjo e a correção dos erros da humanidade na peça em questão representada pelo diabo.

\footnotetext{
${ }^{130}$ Disponível em: <http://www.coloribus.com/adsarchive/prints-outdoor/papermate-angel-vs-demon-19120705/> Acesso em: $15 / 03 / 15$
} 


\section{CONCLUSÃO}

Sendo apresentados à sociedade como mensageiros divinos e personagens na maioria das vezes secundários nos livros sagrados religiosos, os anjos têm conquistado relevância nas manifestações artísticas e culturais. Isto porque o arquétipo do anjo permitiu que com o transcorrer das épocas sua concepção no imaginário coletivo também fosse alterada, fazendo deste ser celestial um personagem complexo em função de todas as características que lhe são impostas.

Sendo seres culturalmente construídos, os anjos, com o passar dos anos, tiveram sua representação e forma alteradas na História e a maneira como estas foram e têm sido produzidas também. Desta forma, a existência dos mitos arquetípicos permanece sempre viva nessas narrativas como forma de despertar desejos e aspirações nos seres humanos.

Sabedora dessas necessidades da sociedade, a propaganda valeu-se desse tipo de abordagem para chamar a atenção em campanhas publicitárias que estimulassem a imaginação, visando levar as pessoas ao consumo de produtos e serviços e utilizou-se da reconstituição do valor simbólico do anjo, no qual este ser idealizado acaba por sofrer interferências indiretas com fins comerciais.

Para isso, até hoje, utiliza-se de concepções baseadas no imaginário coletivo, buscando possíveis paralelismos ou similitudes com os comportamentos e as relações sociais para a divulgação de mensagens. Porém, ao empregar o mito do anjo visando facilitar a compreensão de ideias e conceitos, acabam por empregar muitas vezes sugestões de padrões de vida, que podem corroborar em exigências excessivas em uma sociedade não homogênea, nem na forma de pensar, muito menos na de agir, sem mencionar o limiar financeiro.

Em função desta heterogeneidade, notamos que com o passar do tempo, os paradigmas vão sendo alterados moldando-se aos contextos sugeridos nos anúncios publicitários, permitindo um emprego de formas distintas, buscando captar a complexa formação politeísta da sociedade.

Sendo assim, podemos afirmar que na publicidade, o que até então era considerada uma imagem arquetípica do anjo transmuta-se em imagens que são utilizadas na comercialização de produtos onde é possível encontrarmos de tudo, desde a dessacralização deste mito até seus estereótipos.

Visando simplificar a comunicação nos anúncios, a publicidade, ao transformar 
imagens arquetípicas em mitos midiáticos, coleta apenas uma ou outra características dentre as diversas relações existenciais do mito, restringindo-o a ínfimo elemento imagético reduzindo a complexidade do mito original.

A necessidade de pertencimento a um grupo social é contundente na sociedade contemporânea e, por esta razão, ainda muito voltada para a estética padronizada da produção em larga escala. Ou seja, enquanto no mito original são mantidos os padrões universais que são constantes e perduram por diferentes séculos e culturas mesmo possuindo divergências regionais ou sociais, o mito midiático utilizado na publicidade busca no mito original apenas um elo ou característica para posteriormente através de campanhas e anúncios impor modelos de consumo e comportamento, justamente levando em conta a emoção e a heterogeneidade existente, seja ela social, ambiental ou de gênero, como cita Sal Randazzo em seu livro "A criação de Mitos na Publicidade", quando diz que:

\footnotetext{
"a grande fascinação exercida por uma imagem arquetípica está no fato de as pessoas responderem a ela não só em nível consciente, como também num nível emotivo mais profundo, instintivo. Deste modo, a resposta humana aos arquétipos é quase sempre emocional (RANDAZZO, 1996, p. 102)
}

Os mitos, em detrimento de seu caráter universal e atemporal, permitem adaptações independente da época ou lugar em que são contextualizados e estão sempre em constante atualização. A publicidade vale-se desta reatualização incutindo nas marcas e produtos simbologias que estruturem tal mito revisitado, pois o mito decodifica os arquétipos de maneira que a sociedade os compreenda, representando-os em anúncios que transmitam valores, pensamentos, sentimentos latentes.

Tal decodificação acaba por causar um processo de banalização, pois ao configurar o mito para que determinados grupos sociais o compreendam e se sintam inseridos ou diferenciados, ao mesmo tempo a publicidade transmite crenças e códigos de conduta em que estes membros da sociedade devam se encaixar. De tal forma que podemos afirmar que a publicidade, ao utilizar-se dos arquétipos mitológicos, visa atingir muito mais as impressões inconscientes do que as conscientes dos consumidores.

Desta forma, concluímos que por integrarem parte do universo humano, os símbolos possuem grande relevância para a sociedade permitindo-lhe utilizá-lo como forma de significação para os acontecimentos da vida. Cabe então à sociedade contemporânea, permanecer utilizando-os com esta intenção de modo que seja sempre possível reatualizá-los 
dentro de diferentes contextos, inclusive através da publicidade, que busca ser um espelho da vida.

É preciso sim que estes símbolos universais tão importantes como a figura do anjo que permeiam e direcionam culturalmente o homem com relação a sua origem e essência sejam continuamente atualizados e renovados para que se impeça sua degradação.

E neste ponto, a publicidade é peça chave vital para que isso ocorra, visto que, mesmo sendo conduzida para uma grande massa, ainda assim aufere êxito em atingir cada sujeito em sua singularidade, em função de vivências e repertórios particulares que constituem personalidades próprias, transferindo para a sociedade atitudes, expectativas e fantasias. 


\section{REFERÊNCIAS}

AGOSTINHO. A Cidade de Deus Volume II. Trad. de J. Dias Pereira. Lisboa: Fundação Calouste Goulbekian, 2000.

AQUINO, Victor. Victor Aquino Gomes Correa. Introdução a Estética. Ed. Inmood. São Paulo. 2012. E-commerce. Disponível em: < http://www.youblisher.com/p/398792INTRODUCAO-A-ESTETICA/ > Acesso no dia 11/07/13

AQUINO, Victor. Victor Aquino Gomes Correa. A revolução dos Feios. Ed. Inmood. São Paulo. 2012. E-commerce. Disponível em: < http://www.youblisher.com/p/398746-AREVOLUCAO-DOS-FEIOS/> Acesso no dia 11/07/13

AQUINO, Victor. Victor Aquino Gomes Correa. Estética: Significação, Categorização, Presunção. Ed. Inmod Instituto Da Moda, São Paulo, 2008.

ARIÈS, Philippe. História Social da Criança e da Família. Tradução de Dora Flasksman. 2a . Edição. Editora LTC. Rio de Janeiro, 1981 - Disponível em: <http://www.faroldoconhecimento.com.br/livros/Educação/PHILIPPE-ARIES-Historiasocial-da-crianca-e-da-familia.pdf > Acesso em: 14/04/2014

ARIÈS, Philippe. História Social da Criança e da Família. Tradução de Dora Flasksman. $2^{\mathrm{a}}$. Edição. Editora LTC. Rio de Janeiro, 1981

BAYER, Raymond. História da Estética. Tradução José Saramago. $1^{\text {a }}$. Edição. Editoral Estampa. Lisboa, 1995.

BENJAMIN, W. Origem do drama barroco alemão. Tradução de Sérgio Paulo Rouanet. São Paulo: Brasiliense, 1984.

BLAU \& KOHLER. Ludwig, Kaufmann. Angelology. In Jewish Encyclopedia, disponível em: <http://www.jewishencyclopedia.com/articles/1521-angelology>; Acesso em: 8 de outubro de 2013.

BRANDÃO, Junito de Souza. Dicionário mítico-etimológico da mitologia grega - Volume I. $2^{\text {a. }}$ Edição. Petrópolis, RJ: Vozes, 1991. 
BRANDÃO, Junito de Souza. Dicionário mítico-etimológico da mitologia grega - Volume II. $2^{\text {a. }}$ Edição. Petrópolis, RJ: Vozes, 1991.

CAMPBELL, Joseph. E por falar em mitos: conversas com Joseph Campbell. Campinas: Verus, 2004.

CAMPBELL, Joseph. O poder do mito / Joseph Campbell, com Bill Moyers ; org. por Betty Sue Flowers. tradução de Carlos Felipe Moisés. - São Paulo: Palas Athena, 1990

CARNEIRO, Fernanda Maria Trentini. Sobre anjos e suas asas na arte. Dissertação de Mestrado em Artes Visuais - Orientadora: Dr. ${ }^{a}$ Sandra Makowiecky. Universidade do Estado de Santa Catarina, Centro de Artes, Florianópolis: 2010.

CHAMPEAUX, Fernand. Les Dioscures au servisse d'une déesse. Paris, 1935;

CHEVALIER, Jean. Dicionário de símbolos (mitos, sonhos, costumes, gestos, formas, figuras, cores números). Jean Chevalier, Alain Gheerbrant. 8ª Edição. Rio de Janeiro. José Olympio Editora, 1994.

CHEVALIER, Jean e GHEERBRANT, Alain. Dicionário de Símbolos: (mitos, sonhos, costumes, gestos, formas, figuras, cores, números). Trad: Vera da Costa e Silva. 23 ed. Rio de Janeiro: José Olympio, 2009.

DIEL, Paul. Le Symbolismo dans la mythologie grecque. Prefácio de G. Bachelard, Paris, 1966, p.50

ECO, Umberto. Arte e Beleza na Estética Medieval - Rio de Janeiro: Record, 2010.

ERICKSON, Millard J. Introdução à teologia sistemática. São Paulo: Vida Nova, 1997

FONTANA, David. A linguagem dos símbolos: a história e os significados ocultos em um guia completo e ilustrado. Tradução Livia Chede Almendary. São Paulo: Publifolha, 2012.

FOX, Matthew. A física dos anjos: uma visão científica e filosófica dos seres celestiais. São Paulo: Aleph, 2008.

GOMBRICH, E.H. A história da arte. (Tradução Álvaro Cabral) 16a. edição, Rio de Janeiro: Editora LTC, 1999. 
HALL, Stuart. A identidade cultural da pós-modernidade. 11a. edição. Rio de Janeiro. DP\&A. 2011.

HARVEY, David. Condição pós-moderna. São Paulo. Loyola, parte IV. P. 293-326. 1993.

HURLBUT, Jesse Lyman. História da igreja cristã. Edição em português. Miami, Florida: Editora Vida, 1979

JANSON, H.W. Iniciação à história da arte. H.W. Janson, Anthony F. Janson; (Tradução Jefferson Luiz Camargo) - 3a. edição, São Paulo: Editora WMF Martins Fontes, 2009.

JANSON, H.W. História da arte. (Tradução de J.A. Ferreira de Almeida, Maria Manuela Rocheta Santos, colaboração de Jacinta Maria Matos) 5a. edição, São Paulo: Martins Fontes, 1992.

JÚNIOR, Mário Sérgio Teodoro da Silva. As relações semânticas entre as figuras do Vampiro e do anjo na ficção contemporânea. Relatório de pesquisa de Iniciação Científica. <http://www.academia.edu/8434953/As_relações_semânticas_entre_as_figuras_ficcionais_do _vampiro_e_do_anjo_na_ficção_contemporânea> Araraquara/SP. UNESP 2014.

KURY, Mário da Gama. Dicionário de Mitologia: grega e romana. $6^{\mathrm{a}}$ Ed. Rio de Janeiro : Jorge Zahar Ed. 2001.

LE GOFF, Schmitt; Jacques, Jean-Claude. Dicionário Temático do Ocidente Medieval: Anjos. [S.l.: s.n.], 2002. 69-81 p. vol. 1. ISBN 85-746-147-0 David Keck. Angels and angelology in the Middle Age. 1998.

LERMEN, Ionara Cristine. Anjos no cinema: na perspectiva dos estudos de comunicação e semiótica. Dissertação de Mestrado. PUC-SP. São Paulo, 2013.

LÉVI-STRAUSS, Claude. Mito e significado. Lisboa: Edições 70, 1989.

LEWIS, James R; Oliver, Evelyn Dorothy. Enciclopédia dos Anjos. Tradução Daniel Vieira; Revisão técnica: Phillipe Piet van Putten. São Paulo, Makron Books. 1999.

LIMA, Cláudia de Castro. Do céu ao inferno. Revista Mundo Estranho, São Paulo, Edição No. 143. Setembro de 2013. P. 19-25 
LOES, João. O poder dos Anjos. ISTOÉ, São Paulo, no 2197. Ano 35. p. 84-91, dez. 2011 .

LOPES, Maria Immacolata V. Pesquisa em comunicação. São Paulo: Loyola, 2010. 11a. edição.

MEYER \& TEIXEIRA, Bruno, Jerônimo. A inspiração eterna dos Anjos. VEJA, São Paulo, no 51. Ano 43. p. 150. Edição 2196. dez. 2010.

NÉRET, G. Angels. Tradução de Vanessa Marques. Itália: Taschen, 2003.

PEIRCE, Charles Sanders. A fixação das crenças. Tradução de Octanny Silveira da Mota e Leônidas Hegenberg. São Paulo: Cultrix, 1975, p. 71-92.

PROPHET, Elizabeth Clare. Anjos caídos e as origens do mal: por que a Igreja ocultou o livro de Enoque e suas impressionantes revelações. $3^{\mathrm{a}}$. Edição - Rio de Janeiro: Record Nova Era, 2004.

RANDAZZO, Sal. A criação de mitos na publicidade: como os publicitários usam o poder do mito e do simbolismo para criar marcas de sucesso . Rio de Janeiro: Editora Rocco, 1996.

SHARP, Daryl. Léxico Junguiano. São Paulo: Editora Cultrix, 1991.

TIRAPELLI, Percival. Arte sacra colonial - Barroco memória viva. São Paulo: UNESP, 2005.

VIARO, Mário Eduardo. Por trás das palavras: manual de etimologia do português. $1^{\mathrm{a}}$. Edição. São Paulo: Editora Globo, 2004

WILKINSON, Philip. Mitos \& Lendas: Origens e Significados (Tradução de Angela Maria Moreira Dias, Jefferson Luiz Camargo, Simone Campos) 2a. edição, São Paulo: WMF Martins Fontes, 2012. 